\title{
PRODUCTION OF BIO-BASED CHEMICALS AND POLYMERS FROM RENEWABLE FEEDSTOCKS: BIOPROCESSES DEVELOPMENT
}

\author{
PhD Dissertation by
}

Daniel A. Bustamante Jaramillo

\author{
Supervisors: Antonia Rojas Martínez \\ Marta Tortajada Serra
}

Academic tutor: Eduardo Palomares Gimeno

September, 2021 



\section{Table of contents}

$\begin{array}{ll}\text { Abstract } & 1\end{array}$

$\begin{array}{lr}\text { General introduction } & 13\end{array}$

$\begin{array}{ll}\text { Introduction: Sustainable chemistry and circular bioeconomy } & 15\end{array}$

The biorefinery concept for bioenergy and bioproducts generation 20

Renewable resources towards circular bio-based economy 24

Industrial biotechnology, biocatalysis and biomass conversion 28

Bio-based chemicals and polymers for sustainable development 31

References 39

$\begin{array}{ll}\text { Justification, objectives and scope } & 49\end{array}$

$\begin{array}{ll}\text { Experimental work and results } & 55\end{array}$

List of Publications

CHAPTER I- In silico prospection of microorganisms to produce polyhydroxyalkanoate from whey: Caulobacter segnis DSM 29236 as a suitable industrial strain 59

1.1. Background and aim 60

1.2. Materials and methods $\quad 62$

1.3. Results and discussion 66

$\begin{array}{lr}\text { 1.4. Conclusion } & 80\end{array}$

$\begin{array}{ll}\text { References } & 80\end{array}$

CHAPTER II- Camelina oil as a promising substrate for mcl-PHA production in Pseudomonas sp. Cultures $\quad 89$

2.1 Background and aim 90

2.2 Materials and methods $\quad 92$

$\begin{array}{ll}2.3 \text { Results and discussion } & 94\end{array}$

$\begin{array}{ll}2.4 \text { Conclusion } & 100\end{array}$

$\begin{array}{ll}\text { References } & 101\end{array}$ 
CHAPTER III- Improved Raoultella planticola strains for the production of 2,3-butanediol $\begin{array}{ll}\text { from glycerol } & 105\end{array}$

$\begin{array}{ll}3.1 \text { Background and aim } & 106\end{array}$

$\begin{array}{ll}3.2 \text { Materials and methods } & 107\end{array}$

$\begin{array}{ll}3.3 \text { Results and discussion } & 111\end{array}$

$\begin{array}{ll}3.4 \text { Conclusion } & 117\end{array}$

$\begin{array}{ll}\text { References } & 118\end{array}$

CHAPTER IV- Microbial production of 2,3-Butanediol from the organic fraction of municipal solid waste

$\begin{array}{ll}\text { 4.1 Background and aim } & 122\end{array}$

$\begin{array}{ll}\text { 4.2 Materials and methods } & 123\end{array}$

$\begin{array}{ll}4.3 \text { Results and discussion } & 126\end{array}$

$\begin{array}{ll}4.4 \text { Conclusion } & 133\end{array}$

$\begin{array}{ll}\text { References } & 134\end{array}$

CHAPTER V-Production of D-lactic acid by the fermentation of orange peel waste hydrolysate by lactic acid bacteria 139

$\begin{array}{ll}5.1 \text { Background and aim } & 140\end{array}$

5.2 Materials and methods 142

$\begin{array}{ll}5.3 \text { Results and discussion } & 144\end{array}$

$\begin{array}{ll}5.4 \text { Conclusion } & 151\end{array}$

$\begin{array}{ll}\text { References } & 151\end{array}$

$\begin{array}{ll}\text { Integrative discussion } & 157\end{array}$

$\begin{array}{ll}\text { Renewable bioprocessing to bio-based chemicals and polymers } & 159\end{array}$

$\begin{array}{ll}\text { Direct polyhydroxyalkanoates production from food byproducts } & 161\end{array}$

Improvement and upscaling of 2,3-butanediol production from bio-residues 163

Production of D-lactic acid with high enantiomeric excess using citrus waste 164

Prospects for bioprocesses development using renewable resources 165

$\begin{array}{ll}\text { References } & 166\end{array}$

$\begin{array}{ll}\text { Conclusions and future work } & 169\end{array}$

$\begin{array}{ll}\text { Contributions } & 173\end{array}$

Index of abbreviations $\quad 175$ 
ABSTRACT

The use of by-products to produce biofuels, energy and basic chemicals is increasingly necessary in the current situation of oil shortages and environmental concern. Many compounds that have traditionally been produced from oil can now be synthesised in a biotechnological way using renewable resources. In this context, microorganisms can be effectively used as biocatalysts to carry out these transformations. With this type of process, waste streams or renewable raw materials can be used to obtain products of interest such as bioplastics of microbial origin or chemical products that can serve as monomers for the synthesis of biodegradable plastics or other types of applications. Environmental pollution caused by non-biodegradable synthetic polymer waste is a growing problem due to the stability of compounds derived from fossil fuels. In contrast, bioplastics can be obtained from renewable sources, which enables the development of sustainable production processes.

In this research work, bioprocesses for the production of polyhydroxyalkanoates, 2,3-butanediol and D-lactic acid using renewable raw materials such as cheese whey, camelina oil, glycerine, organic waste and orange waste were studied and developed. The characterisation of the raw materials was carried out using compositional analysis, HPLC analysis, gas chromatography and spectrophotometric techniques, among others. With these results, a selection of bacterial strains capable of synthesising the products of interest from the selected substrates was made. Once the strains were selected, the work was focused on process development in order to optimize fermentation yields and scale-up.

Polyhydroxyalkanoates (PHAs) are polyesters of microbial origin that can be synthesized by prokaryotes from noble sugars or lipids and from complex renewable substrates. They are an attractive alternative to conventional plastics because they are biodegradable and can be produced from renewable resources, such as the surplus of whey from dairy companies. In Chapter I, after an in silico screening to search for ß-galactosidase and PHA polymerase genes, several bacteria were identified as potential PHA producers from whey based on their ability to hydrolyze lactose. Among them, Caulobacter segnis DSM 29236 was selected as a suitable strain to develop a process for whey surplus valorization. This microorganism accumulated $31.5 \%$ of cell dry weight (CDW) of poly(3-hydroxybutyrate) (PHB) with a titer of $1.5 \mathrm{~g} \mathrm{l}^{-1}$ in batch assays. Moreover, the strain accumulated $37 \%$ of CDW of PHB and $9.3 \mathrm{~g}^{-1}$ in fed-batch mode of operation. This study reveals this species as a PHA-producer and experimentally validates the in silico bioprospecting strategy for selecting microorganisms for waste valorization. 
Medium-chain-length Polyhydroxyalkanoates ( $m c /$-PHAs) show interesting properties as elastic and adhesive specialty polymers. Moreover, mcl-PHAs producers such as Pseudomonas sp. have demonstrated high yields on fats and oils. In Chapter II, Camelina oil was for the first time tested for the production of mcl-PHAs by different Pseudomonas strains. Camelina sativa is a low-input, non-food chain competing crop, whose seed consists in about $43 \%$ oil in dry matter with about $90 \%$ of unsaturated fatty acids. The use of Pseudomonas resinovorans enables direct fermentation of this substrate without prior hydrolysis to release fatty acids. A first approach to process development in bioreactor has provided up to $40 \%$ (of CDW) polymer content, matching highest mcl-PHA titer reported from plant oils $\left(13.2 \mathrm{~g} \mathrm{I}^{-1}\right)$. In this study, Pseudomonas resinovorans DSM 21078 gave good results of mcl-PHA production using Camelina oil without any pretreatment.

Many compounds traditionally obtained from oil can be synthesized from renewable resources, such as 2,3-butanediol (2,3-BD). This compound is of significant industrial interest (e.g., production of synthetic rubber, food additives, plasticizers, perfumes, antifreeze agent, or octane boosters, among others) and can be produced from sugars or glycerol by different bacteria, mainly class 2 microorganisms. Raw glycerol is an industrial byproduct from biodiesel production and is one of the most promising substrates for 2,3-BD production; however, this compund is not yet produced by fermentation from glycerol on a commercial scale due to poor process economics. In Chapter III, microorganisms of Biosafety Level 1 were screened and Raoultella planticola strain CECT 843 proved to be the best 2,3-BD producer, achieving $23.3 \mathrm{~g} \mathrm{I}^{-1}$ and a yield of $36 \%$ (g 2,3-BD per $\mathrm{g}$ glycerol). To further increase product concentration and yield, $R$. planticola CECT 843 was subjected to random mutagenesis using ultra-violet (UV) light and ethyl methane sulfonate (EMS). In the end, two mutant strains were found to produce at least 30\% more 2,3-BD than the wild type: R. planticola CECT 8158 (33.8 $\mathrm{gl}^{-1}$ and 54\% yield) and R. planticola DSM 8159 (30.5 $\mathrm{g} \mathrm{I}^{-1}$ and 49\% yield). These results exceed the best data previously reported for 2,3-BD from glycerol.

The increasing amount of municipal solid waste has caused a series of environmental problems and therefore the society is facing a serious challenge for its effective management. Organic waste, or biowaste, has promising potential for being used as substrate in bioprocesses. The enzymatic hydrolysis of carbohydrates that form these residues coupled with the production of 2,3-BD via fermentation was carried out in Chapter IV. In this study, Bacillus licheniformis and Raoultella planticola strains were initially selected as efficient 2,3-BD producers. Raoultella planticola (wildtype and improved strains) showed high tolerance and good yields using organic waste hydrolysates in flask trials. Fed-batch strategy in bioreactor using Raoutella planticola CECT 843 led to the production of $54 \mathrm{~g} \mathrm{I}^{-1}$ of 2,3-BD and the process was successfully upscaled at demo scale. Therefore, this study demostrates a procedure to obtaining $2,3-B D$ by fermentation of organic 
waste hydrolysates using Raoultella planticola strains within the biowaste-refinery concept and contributing to the development of sustainable processes (this process was patented).

Lactic acid is one the most interesting monomer candidates to replace some petroleum- based monomers. Application of conventional poly-lactic acid (PLA) is limited due to insufficient thermal properties. This limitation can be overcome by blending poly-D and poly-L-lactic acid. The main problem is the limited knowledge of D-lactic acid (D-LA) production. Orange peel waste (OPW) is an interesting renewable raw material for biorefinery processes of biocatalytic, catalytic or thermal nature owing to its low lignin and ash content. In Chapter V, bioprocessing of the pretreated OPW by enzymatic hydrolysis and fermentation of the released sugars to produce D-LA is carried out. Several strains of the species Lactobacillus delbrueckii ssp. bulgaricus have been evaluated for the production of D-LA from OPW hydrolysate using Lactobacillus delbrueckii ssp. delbrueckii CECT 286 as a reference strain since its performance in this kind of substrate has been widely reported in previous studies. Preliminary results show that Lactobacillus delbrueckii ssp. bulgaricus CECT 5037 had the best performance with a yield of $84 \%$ for D-LA production and up to $95 \%$ enantiomeric excess.

Therefore, this research work provides knowledge on the identification and selection of industrial biocatalysts for the use of renewable feedstocks and industrial wastes for the production of biobased chemicals and polymers. These studies pave the way for further development of sustainable biotechnological processes in the framework of biorefineries and circular bioeconomy. 
RESUMEN

El aprovechamiento de subproductos para producir biocombustibles, energía y compuestos químicos básicos es cada vez más necesario en la situación actual de escasez de petróleo y preocupación por el medioambiente. Muchos compuestos que tradicionalmente han sido producidos a partir del petróleo pueden sintetizarse hoy día de forma biotecnológica empleando recursos renovables. En este contexto, los microorganismos pueden aprovecharse eficazmente como biocatalizadores para llevar a cabo estas transformaciones. Con este tipo de procesos se pueden aprovechar residuos o materias primas renovables para la obtención de productos de interés como bioplásticos de origen microbiano o productos químicos que pueden servir como monómeros para la síntesis de plásticos biodegradables u otro tipo de aplicaciones. La contaminación ambiental causada por los residuos de polímeros sintéticos no biodegradables es un problema en aumento debido a la estabilidad de los compuestos derivados de los combustibles fósiles. En contraste, los bioplásticos pueden obtenerse de fuentes renovables, lo que posibilita el desarrollo de procesos de producción sostenible.

En este trabajo de investigación se han estudiado y desarrollado bioprocesos para la producción de polihidroxialkanoatos, 2,3-butanodiol y ácido D-láctico de forma sostenible empleando materias primas renovables como el suero lácteo de quesería, aceite de camelina, glicerina, fracción orgánica de residuos urbanos y residuos de naranja. La caracterización de las materias primas de partida se realizó mediante técnicas de análisis composicional, análisis en HPLC, cromatografía de gases y técnicas espectrofotométricas. Con estos resultados se hizo una selección de cepas bacterianas capaces de sintetizar los productos de interés a partir de los sustratos seleccionados. Una vez seleccionadas las cepas, el trabajo se centró en el desarrollo de los procesos para conseguir buenos rendimientos de fermentación y su escalado.

Los polihidroxialcanoatos (PHA) son poliésteres de origen microbiano que pueden ser sintetizados por procariotas a partir de azúcares o lípidos nobles y de sustratos renovables complejos. Son una alternativa atractiva a los plásticos convencionales porque son biodegradables y pueden producirse a partir de recursos renovables, como el excedente de suero lácteo de queserías. En el capítulo I, tras un cribado in silico para buscar genes de ß-galactosidasa y de PHA polimerasa, se identificaron varias bacterias como potenciales productoras de PHA a partir de suero lácteo en función de su capacidad para hidrolizar la lactosa. Entre ellas, se seleccionó Caulobacter segnis DSM 29236 como cepa adecuada para desarrollar un proceso de valorización de los excedentes de suero lácteo. Este microorganismo acumuló un 31,5\% de peso seco celular (CDW) de poli(3-hidroxibutirato) (PHB) con 
una concentración de 1,5 $\mathrm{g} \mathrm{I}^{-1}$ en ensayos en batch. Además, la cepa acumuló un 37\% de CDW de PHB y $9,3 \mathrm{~g} \mathrm{I}^{-1}$ en modo fed-batch. Este estudio revela esta especie como productora de PHA y valida experimentalmente la estrategia de bioprospección in silico para seleccionar microorganismos para la valorización de residuos.

Los polihidroxialcanoatos de longitud de cadena media (mcl-PHAs) muestran propiedades interesantes como polímeros especiales siendo elásticos y adhesivos. Además, los microorganismos productores de mcl-PHAs, como Pseudomonas sp., han demostrado rendimientos elevados usando grasas y aceites. En el capítulo II, se probó por primera vez el aceite de Camelina para la producción de mcl-PHAs empleando distintas cepas de Pseudomonas. La Camelina Sativa es un cultivo de bajos insumos que no compite con la cadena alimentaria, cuya semilla consiste en aproximadamente un $43 \%$ de aceite en materia seca con cerca de un $90 \%$ de ácidos grasos insaturados. El uso de Pseudomonas resinovorans permite la fermentación directa de este sustrato sin hidrólisis previa para liberar los ácidos grasos. Una primera aproximación al desarrollo del proceso en biorreactor ha proporcionado hasta un $40 \%$ (de CDW) de contenido polimérico, igualando la mayor concentración de mcl-PHA reportado a partir de aceites vegetales $\left(13,2 \mathrm{~g} \mathrm{I}^{-1}\right)$. En este estudio, Pseudomonas resinovorans DSM 21078 dio buenos resultados de producción de mcl-PHA utilizando aceite de camelina sin ningún pretratamiento.

Muchos compuestos que tradicionalmente se obtienen del petróleo pueden sintetizarse a partir de recursos renovables, como el 2,3-butanediol (2,3-BD). Este compuesto tiene un gran interés industrial (por ejemplo, para la producción de caucho sintético, aditivos alimentarios, plastificantes, perfumes, anticongelantes o potenciadores del octanaje, entre otros) y puede ser producido a partir de azúcares o glicerol por diferentes bacterias, principalmente microorganismos de clase 2. El glicerol crudo es un subproducto industrial de la producción de biodiésel y es uno de los sustratos más prometedores para la producción de 2,3-BD; sin embargo, este compuesto aún no se produce por fermentación a partir del glicerol a escala comercial debido a la escasa rentabilidad del proceso. En el capítulo III, se evaluaron microorganismos de Nivel de Bioseguridad clase 1 y la cepa Raoultella planticola CECT 843 resultó ser la mejor productora de 2,3-BD, alcanzando 23,3 $\mathrm{gl}^{-1} \mathrm{y}$ un rendimiento del 36\% (g de 2,3-BD por g de glicerol). Para aumentar aún más la concentración de producto y el rendimiento, Raoultella planticola CECT 843 fue sometida a mutagénesis aleatoria utilizando luz ultravioleta (UV) y etil metanosulfonato (EMS). Al final, se encontró que dos cepas mutantes producían al menos un 30\% más de 2,3-BD que la cepa salvaje: $R$. planticola CECT 8158 (30,8 $\mathrm{g} \mathrm{I}^{-1}$ y $49 \%$ de rendimiento) y $R$. planticola DSM 8159 (30,5 $\mathrm{g} \mathrm{I}^{-1}$ y $49 \%$ de rendimiento). Estos resultados superan los mejores datos descritos con anterioridad para la producción de 2,3-BD a partir del glicerol. 
La creciente cantidad de residuos sólidos urbanos ha provocado una serie de problemas medioambientales y, por tanto, la sociedad se enfrenta a un serio reto para su gestión eficaz. Los residuos orgánicos, o biorresiduos, tienen un uso potencial y prometedor como materia prima en bioprocesos. En el capítulo IV se llevó a cabo la hidrólisis enzimática de los carbohidratos que contienen estos residuos junto con la producción de 2,3-BD mediante fermentación. En este estudio, se seleccionaron inicialmente cepas de Bacillus licheniformis y Raoultella planticola como productores eficientes de 2,3-BD. Raoultella planticola (cepas de tipo salvaje y mejoradas) mostró una alta tolerancia y buenos rendimientos utilizando hidrolizados de residuos orgánicos en ensayos en matraz. La estrategia de fermentación en fed-batch en biorreactor utilizando Raoutella planticola CECT 843 condujo a la producción de $54 \mathrm{~g} \mathrm{I}^{-1}$ de 2,3-BD y el proceso se escaló con éxito a escala de demostración. Por lo tanto, este estudio demuestra un procedimiento para obtener 2,3BD por fermentación de hidrolizados de residuos orgánicos utilizando cepas de Raoultella planticola dentro del concepto de biorrefinería y contribuyendo al desarrollo de procesos sostenibles (este proceso fue patentado).

El ácido láctico es uno de los candidatos más interesantes para sustituir a algunos monómeros derivados del petróleo. La aplicación del ácido poliláctico (PLA) convencional está limitada por sus insuficientes propiedades térmicas. Esta limitación puede superarse mediante la generación de mezclas de ácido poli-D y poli-L-láctico. El principal problema es el escaso conocimiento de la producción de ácido D-láctico (D-LA). Los residuos de cáscara de naranja (OPW) son una interesante materia prima renovable para los procesos de biorrefinería de naturaleza biocatalítica, catalítica o térmica debido a su bajo contenido en lignina y cenizas. En el capítulo V se lleva a cabo el bioprocesamiento del OPW pretratado mediante hidrólisis enzimática y fermentación de los azúcares liberados para producir D-LA. Se han evaluado varias cepas de la especie Lactobacillus delbrueckii ssp. bulgaricus para la producción de D-LA a partir del hidrolizado de OPW utilizando Lactobacillus delbrueckii ssp. delbrueckii CECT 286 como cepa de referencia ya que su rendimiento en este tipo de sustrato ha sido ampliamente reportado en estudios anteriores. Los resultados preliminares muestran que Lactobacillus delbrueckii ssp. bulgaricus CECT 5037 tuvo el mejor rendimiento con un $84 \%$ para la producción de D-LA y hasta un 95\% de exceso enantiomérico.

Por lo tanto, este trabajo de investigación aporta conocimientos sobre la identificación y selección de biocatalizadores industriales para el uso de materias primas renovables y residuos industriales para la producción de productos químicos y polímeros de base biológica. Estos estudios allanan el camino para el futuro desarrollo de procesos biotecnológicos sostenibles en el marco de las biorrefinerías y de la bioeconomía circular. 
RESUM

L'aprofitament de bioproductes per produir biocombustibles, energia i compostos químics bàsics és cada vegada més necessari en la situació actual d'escassetat de petroli i preocupació pel medi ambient. Molts compostos que tradicionalment s'han produït a partir de petroli es poden sintetitzar hui en dia biotecnològicament utilitzant recursos renovables. En aquest context, els microorganismes es poden utilitzar eficaçment com a biocatalitzadors per dur a terme aquestes transformacions. Amb aquest tipus de processos es poden utilitzar residus o matèries primeres renovables per obtenir productes d'interès com bioplàstics d'origen microbià o químics que puguen servir de monòmers per a la síntesi de plàstics biodegradables o altres aplicacions. La contaminació ambiental causada per residus de polímers sintètics no biodegradables és un problema creixent a causa de l'estabilitat dels compostos de combustibles fòssils. Per contra, els bioplàstics es poden obtenir a partir de fonts renovables, permetent el desenvolupament de processos productius sostenibles.

En aquest treball de recerca s'han estudiat i desenvolupat bioprocessos per a la producció de polihidroxialcanoats, 2,3-butanodiol i àcid D-làctic de manera sostenible utilitzant matèries primeres renovables com sèrum de llet, oli de camelina, glicerina, fracció orgànica de residus urbans i residus de taronges. La caracterització de matèries primeres inicials es realitza mitjançant tècniques d'anàlisi composicional, anàlisi HPLC, cromatografia de gasos i tècniques espectrofotomètriques. Amb aquests resultats es crea una selecció de soques bacterianes capaç de sintetitzar els productes d'interès dels substrats seleccionats. Una vegada seleccionades les soques, el treball es va centrar en el desenvolupament dels processos per aconseguir uns bons rendiments de fermentació i el seu escalat.

Els polihidroxialcanoats ( $\mathrm{PHA}$ ) són polièsters microbians que poden ser sintetitzats per procariotes partint de sucres o lípids nobles i de substrats renovables complexos. Són una alternativa atractiva als plàstics convencionals perquè són biodegradables $i$ es poden produir a partir de recursos renovables, com l'excedent de sèrum de llet derivat de la producció de formatge. En el capítol I, després del cribratge in silico per buscar gens de ß-galactosidasa i PHA polimerasa, diverses soques van ser identificades com a potencials productores de PHA a partir del sèrum de llet en funció de la seua capacitat d'hidrolitzar la lactosa. Entre elles, Caulobacter segnis DSM 29236 va ser seleccionada com una soca adequada per desenvolupar un procés de valorització d'excedents de sèrum de llet. Aquest microorganisme va acumular un 31,5\% de pes cel-lular sec (CDW) de poli(3hidroxibutirat) (PHB) amb una concentració $\mathrm{d}^{\prime} 1,5 \mathrm{~g} \mathrm{I}^{-1}$ en proves batch. A més, la soca també 
acumulava un 37\% de PHB CDW i 9,3 $\mathrm{gl}^{-1}$ en fed-batch. Aquest estudi revela aquesta espècie com a productora de PHA i valida experimentalment l'estratègia de bioprospecció in silico per a la selecció de microorganismes per a la valorització de residus.

Els polihidroxialcanoats de longitud de cadena mitjana (mcl-PHAs) mostren propietats interessants com a polímers especials, essent elàstics i adhesius. A més, els microorganismes productors de mclPHAs, com Pseudomonas sp., han mostrat alts rendiments utilitzant greixos i olis. En el capítol II, I'oli de camelina es va provar per primera vegada per a la producció de mcl-PHAs utilitzant distintes soques de Pseudomonas. Camelina sativa és un cultiu que no requereix massa recursos i, a més a més, no competeix amb la cadena alimentària. La llavor d'aquesta planta conté aproximadament un $43 \%$ d'oli en matèria seca amb un $90 \%$ d'àcids grassos insaturats. L'ús de Pseudomonas resinovorans permet la fermentació directa d'aquest substrat sense hidròlisi prèvia per alliberar àcids grassos. Una primera aproximació al desenvolupament del procés en bioreactor ha proporcionat fins a un $40 \%$ (CDW) de contingut polimèric, igualant la major concentració de mclPHA reportada a partir d'olis vegetals $\left(13,2 \mathrm{gl}^{-1}\right)$. En aquest estudi, Pseudomonas resinovorans DSM 21078 va donar bons resultats de producció mcl-PHA utilitzant oli de camelina sense cap pretractament.

Molts compostos tradicionalment obtinguts a partir de petroli es poden sintetitzar partint de recursos renovables, com el 2,3-butanediol (2,3-BD). Aquest compost té un gran interès industrial (per exemple, per a la producció de cautxú sintètic, additius alimentaris, plastificants, perfums, anticongelants o potenciadors d'octanatge, entre d'altres) i es pot produir a partir de sucres o glicerol per diferents bacteris, principalment microorganismes de classe 2. El glicerol cru és un subproducte industrial de la producció de biodièsel i és un dels substrats més prometedors per a la producció de 2.3-BD; no obstant això, aquest compost encara no es produeix a partir de la fermentació del glicerol a escala comercial a causa de la baixa rendibilitat del procés. En el capítol III es van avaluar microorganismes de Nivell de Bioseguretat 1 i la soca Raoultella planticola CECT 843 va resultar ser el millor productor de 2,3-BD, arribant a $23,3 \mathrm{~g} \mathrm{I}^{-1} \mathrm{i}$ un rendiment del $36 \%$ (g de 2,3-BD per g de glicerol). Per augmentar encara més la concentració i el rendiment del producte, Raoultella planticola CECT 843 es va sotmetre a mutagènesi aleatòria mitjançant llum ultraviolada (UV) i metanosulfonat etílic (EMS). Al final, es van trobar dues soques mutants que produeixen almenys un 30\% més de 2,3-BD que la soca silvestre: $R$. planticola CECT $8158\left(30,8 \mathrm{~g} \mathrm{I}^{-1}\right.$ i $49 \%$ de rendiment) i R. planticola DSM 8159 (30,5 $\mathrm{g} \mathrm{I}^{-1}$ i 49\% de rendiment). Aquests resultats superen les millors dades descrites anteriorment per a la producció de 2,3-BD a partir de glicerol.

La creixent quantitat de residus sòlids urbans ha comportat una sèrie de problemes ambientals $i$, per tant, la societat s'enfronta a un seriós repte en la seua gestió eficaç. Els residus orgànics, o bioresidus, tenen un ús potencial i prometedor com a matèria primera en bioprocessos. En el capítol 
IV es va dur a terme la hidròlisi enzimàtica dels carbohidrats que contenen aquests residus juntament amb la producció de 2,3-BD mitjançant fermentació. En aquest estudi, es van seleccionar inicialment soques de Bacillus licheniformis i Raoultella planticola com a productors eficients de 2,3-BD. Raoultella planticola (soques silvestres i millorades) va mostrar una alta tolerància $\mathrm{i}$ bons rendiments utilitzant residus orgànics hidrolitzats en assajos de matràs. L'estratègia de fermentació en fed-batch en bioreactor usant Raoutella planticola CECT 843 va donar lloc a la producció de $54 \mathrm{~g} \mathrm{I}^{-1}$ de 2,3-BD i el procés es va escalar amb èxit a escala de demostració. Per tant, aquest estudi presenta un procediment per obtenir 2,3-BD mitjançant la fermentació de residus orgànics hidrolitzats utilitzant soques de Raoultella planticola dins del concepte de biorefineria i contribuint al desenvolupament de processos sostenibles (aquest procés va ser patentat).

L'àcid làctic és un dels candidats més interessants per reemplaçar alguns monòmers derivats del petroli. L'aplicació de l'àcid polilàctic (PLA) convencional està limitada per les seues insuficients propietats tèrmiques. Aquesta limitació es pot superar generant mescles d'àcid poli-D i poli-L-làctic. El principal problema és el limitat coneixement de la producció d'àcid D-làctic (D-LA). Els residus de pell de taronja (OPW) són una matèria primera renovable interessant per a processos de biorefineria de caràcter biocatalític, catalític o tèrmic pel seu baix contingut en lignina i cendra. Al capítol V es porta a terme el bioprocessament de l'OPW pretractat mitjançant hidròlisi enzimàtica i fermentació dels sucres alliberats per produir D-LA. Diverses soques de I'espècie Lactobacillus delbrueckii ssp. bulgaricus han estat avaluades per a la producció de D-LA a partir de I'OPW hidrolitzat utilitzant Lactobacillus delbrueckii ssp. delbrueckii CECT 286 com a soca de referència ja que el seu rendiment en aquest tipus de substrat ha estat àmpliament reportat en estudis anteriors. Els resultats preliminars mostren que Lactobacillus delbrueckii ssp. bulgaricus CECT 5037 va presentar el millor rendiment amb un $84 \%$ per a la producció de D-LA i fins a un 95\% d'excés enantiomèric.

Per tant, aquest treball de recerca aporta coneixements sobre la identificació i selecció de biocatalitzadors industrials per a l'ús de matèries primeres renovables i residus industrials per a la producció de productes químics i polímers de base biològica. Aquests estudis amplien el coneixement per al futur desenvolupament de processos biotecnològics sostenibles en el marc de la biorefineria i la bioeconomia circular. 


\section{GENERAL INTRODUCTION}




\section{Introduction: Sustainable Chemistry and Circular Bioeconomy}

Chemistry is present in everything that surrounds us and makes our lives easier. Many of the compounds and materials involved in our lives have been prepared through industrial chemical processes, although for decades they were designed without taking into account their impact on the environment. In the 1950s and 1960s, chemistry became a central science, and it was conceived as the solution to a wide variety of society's needs (Brown et al., 1999). The expansion of human technological activity has had a significant impact on economic development worldwide, but the associated environmental impacts were becoming increasingly evident. Thanks to natural and synthetic chemicals, mankind has achieved longevity and a better quality of life, but while the emerging environmental and health problems caused by chemicals in the 1970's and 1980's have been addressed and solved locally, several issues turned into global phenomena (green house gas emission, climate change, ozone depletion, pollution, among many others). Therefore, the effects of human activities on the environment and health have raised global concerns that resulted in the definition of sustainable development and the evolution of green chemistry, which started in the 1980s and has grown as a guiding concept by the end of 1990s (Anastas, 2018).

In 1987, the report entitled "Our common future" of the World Commission on Environment and Development of the United Nations (UN), introduced the concept of sustainable development as: "Sustainable development should meet the needs of the present without compromising the ability of the future generations to meet their own needs". In order to respond to the current and future needs of society, the chemical industry not only has to supply raw materials for various products (including consumer products) but also has to enable the development of advanced materials (such as hybrid and lightweight materials, selfcleaning materials, materials capable of storing and recovering energy) and advanced processes and reactions that enable more sustainable and efficient production in resources and energy. Moreover, thanks to valorisation, chemistry has to favor reuse and the obtaining of products with greater added value. On the other hand, the number of environmental laws, especially those related to the treatment and handling of waste, has increased exponentially, resulting in a significant increase in production costs. In Europe, the European Regulation on Registration, Evaluation, Authorisation and Restriction of Chemicals (REACH EC 1907/2006) came into force in 2007 and aims to improve the protection of human health and the environment through the better and earlier identification of the intrinsic properties of 
chemical substances. The regulation will lead countries to re-evaluate the feasibility of using biomass and biotechnologies for chemical production. Short-term needs can be identified easily, but long term predictions have been unreliable due to fast rate of scientific and technical advances, economic changes or societal transformations and therefore, it is necessary to identify the appropriate goals, indices, and metrics to assess whether a particular product or activity is sustainable (Böhringer and Jochem, 2007; Hay et al., 2014).

In 2015, the UN identified 17 sustainable goals (SDGs, https://unstats.un.org/sds), with specific targets for the next 15 years, including definitions and metrics with the combination of societal, economical and ecological components at different extent. The SDGs will be measured by regional, national and global indicators and require the cooperation of all the sectors of life (Figure 1). The EU has also stated the sustainable development indicators (EU SDI set), which were defined by 10 strategy objectives of sustainable development. Since this combination of objectives or indicators have intermingled societal, ecological and economical issues, the term sustainable could be replaced by suitable due, e.g. to conflicts of interest of stakeholders in generating profits for businesses (Horvàth et al., 2017). An alternative definition of sustainability independent of economic and social aspects and similar to the system conditions of the four principles of sustainability stated by Robèrt et al (1997) was proposed five years ago (Cséfalvay et al., 2015): "Resources, including energy, should be used at a rate at which they can be replaced naturally, and the generation of wastes cannot be faster than the rate of their remediation".

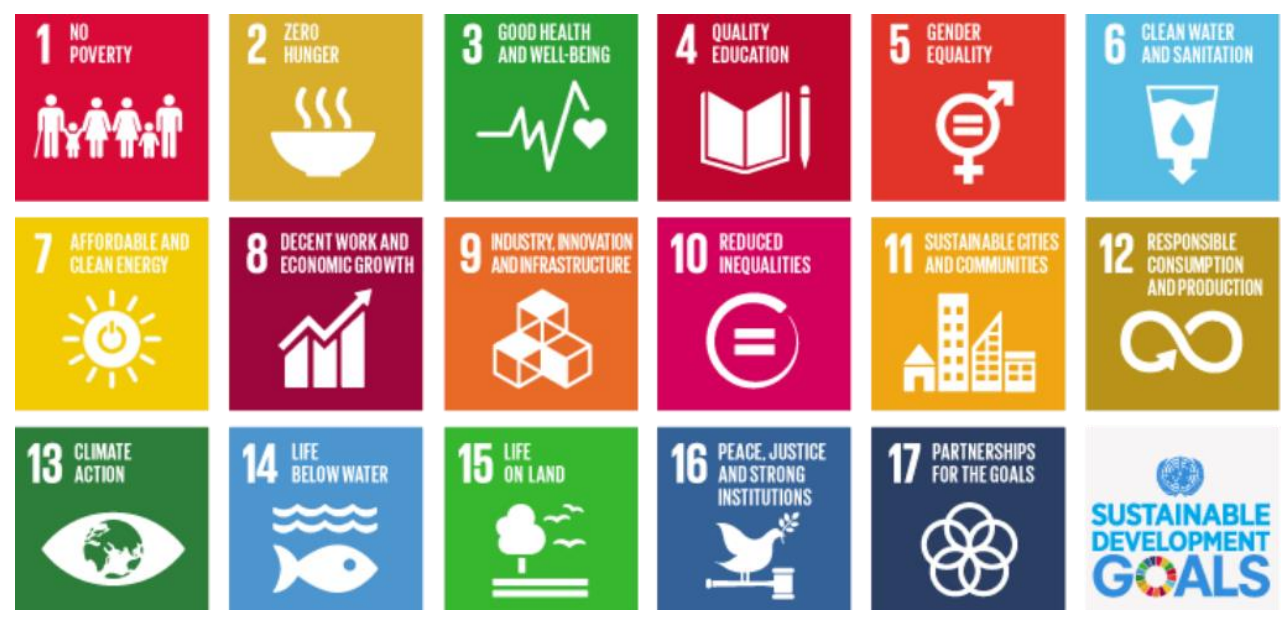

Figure 1. Sustainable development goals (source: https://sdgs.un.org).

In this context, Sustainable Chemistry could be defined as "the design of chemicals and processes that reduce or eliminate the use and generation of harmful substances". The term 
green chemistry was introduced in the 1980s and describes the efforts of chemists to develop processes and products that prevent pollution and are safe for both humans and the environment (Anastas and Kirchhoff, 2002). Sustainable chemistry is therefore directly related to sustainability and some parts of green chemistry may not be sustainable at all, and not all sustainable chemicals or reactions or processes could be green. A definition of sustainable chemistry should be applied and established in each case, and therefore, the achievement of sustainability will be achieved with new technologies that provide society with the products on which we depend, in an environmentally responsible manner. The design of environmentally benign products is guided by the 12 Principles of green chemistry enunciated by Anastas and Warner (1998), which are still valid, indicating their timeless nature and helped to draw the frames in which research and technical work should be performed (Figure 2). One of the frames in which scientific and industrial work is being performed is integration of green chemistry principles in the biorefinery concept to develop new and more sustainable processes based on natural feedstock like biowaste and industrial by-products towards a new circular bioeconomy era (Morais and Bogel-Lukasik, 2013).

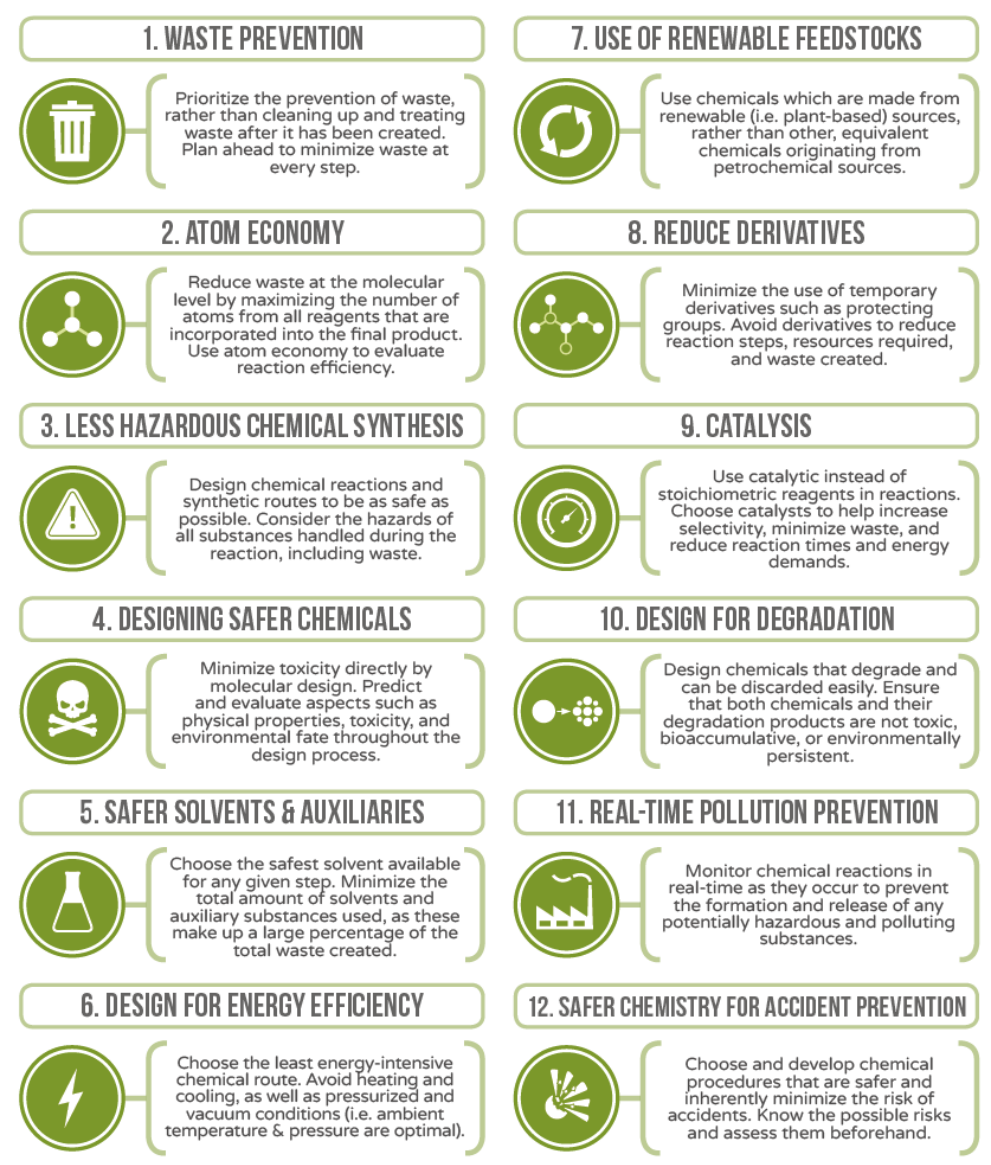

Figure 2. 12 principles of green chemistry (source: https://www.compoundchem.com). 
Sustainable chemistry cannot be seen as a new specialty within chemistry, but as a set of principles for addressing sustainable and suitable development by preventing pollution from the source (Figure 3 ). In this sense, it is a multidisciplinary subject involving the different specialties of chemistry, biochemistry, chemical engineering, toxicology and legislation. On the other hand, it deals with the whole process of making a chemical product, from raw materials, design and research, production, consumption and recycling or disposal

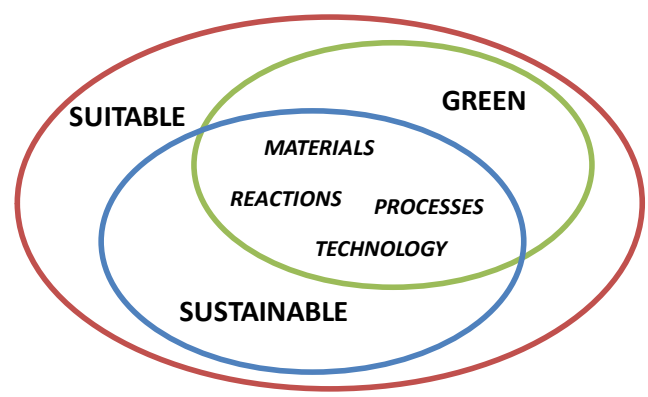

Figure 3. Sustainable, green and suitable development.

Society, business and government have approached sustainability as a goal with different industrial models and from a linear perspective. Even many of the efforts to solve environmental problems are often reduced to corrective or end of pipe techniques and technological upgrading that can buy time, but cannot by itself buy sustainability (Huesemann, 2004). Nowadays, the economy's linear model of "take, make and dispose" is being modified as the "take, make, reuse, recycle and remanufacture" which facilitates significant reduction of the waste generated (Philp and Winickoff, 2018) thus, Circular Economy is a paradigm that aims to generate economic prosperity, protect the environment and prevent pollution, thus facilitating sustainable development. According to the European Commission, "Circular Economy is the economic space where the value of products, materials and resources is maintained in the economy for as long as possible, and the generation of waste minimized".

Therefore, circular economy also strives to dramatically reduce our dependence on fossil resources (coal, oil and natural gas) and waste generation by exploiting renewable resources in a so-called bio-based economy (Patermann and Aguilar, 2018). According to the European Commission, "Bioeconomy is the production of renewable biological resources and the conversion of these resources and waste streams into value added products, such as food, feed, bio-based products and bioenergy". Bioeconomy is often addressed as bio-based economy, while few differentiate both. According to European Commission report of Bio-based Economy in Europe, integration of entire gamut of renewable and natural biological resources through 
processing and their consumption is the scope of bio-based economy (https://op.europa.eu/s/oc0C). In climate change control, the bioeconomy plays a critical role by sequestering carbon dioxide via photosynthesis, storing carbon in the form of bio-based products and utilizing bio-based feedstock. Bioeconomy is building bridges between biotechnology and economy as well as between science, industry, and society. Biotechnology, from its ancient origins up to the present is at the core of the scientific and innovative foundation of bioeconomy policies developed in numerous countries (Aguilar et al., 2019). Importance of bioeconomy is now realized globally and many countries are working on these concepts and strategies.

The intersection of bioeconomy and circular economy can be considered as "circular bioeconomy" (Carus and Dammer, 2018; Mohan et al., 2019). Recently, circular bioeconomy concept was defined via a literature review and considering its elements (Stegmann et al., 2020): "The circular bioeconomy focuses on the sustainable, resource-efficient valorization of biomass in integrated, multi-output production chains (e.g. biorefineries) while also making use of residues and wastes and optimizing the value of biomass over time via cascading" (Figure 4). Out of 17 sustainable development goals (SDGs), 11 SDGs directly align with the scope of circular bioeconomy (Heimann, 2019). Circular bioeconomy is one of the important agenda discussed around the globe and is anticipated to assist in promoting and strengthening the current economic growth (Kalmykova et al., 2018). In some instances, the governments are imposing higher prices on linear end-of use treatment options, which forces/facilitates the reuse and recycling of materials rather than disposal (Mohan et al., 2019). Governments are taking active steps to encourage the stakeholders to innovate and invest in development of circular products and service designs. Despite all these efforts circular economy is still much stronger on paper rather than in the practical sense.

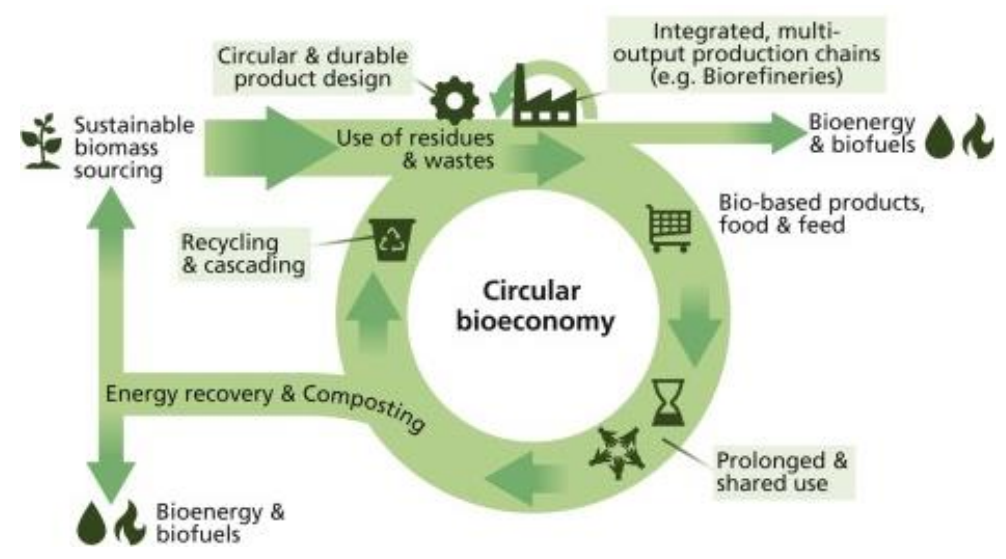

Figure 4. The circular bioeconomy and its elements (Stegmann et al., 2020). 


\section{The Biorefinery concept for Bioenergy and Bioproducts generation}

The conversion of raw materials into value-added products is the core of the chemical industry (Ali et al., 2005; Sheldon, 2018a; Amoah et al., 2019). In the previous era, fossil resources were established as the primary feedstock but its depletion has become the paradigm of "biorefineries" as the answer to sustainable growth (Diep et al., 2012; Morais and BogelLukasik, 2013; Ferreira, 2017)). The concept of biorefineries has emerged as "the production of chemicals, fuels, and power by a facility that incorporates biomass transformation processes" (Figure 5). Advantages of biorefineries are variations in biomass components and intermediates that can eventually maximize the value derived from biomass feedstock. For example, a biorefinery can produce one or several low volume but high-value chemical products and low-value but high-volume liquid transportation fuels (Fiorentino et al., 2017). For the creation of a new biorefinery industry, industrial bioprocesses have been recognized as an auspicious direction (Hossain et al., 2017; loannidoua et al., 2020).

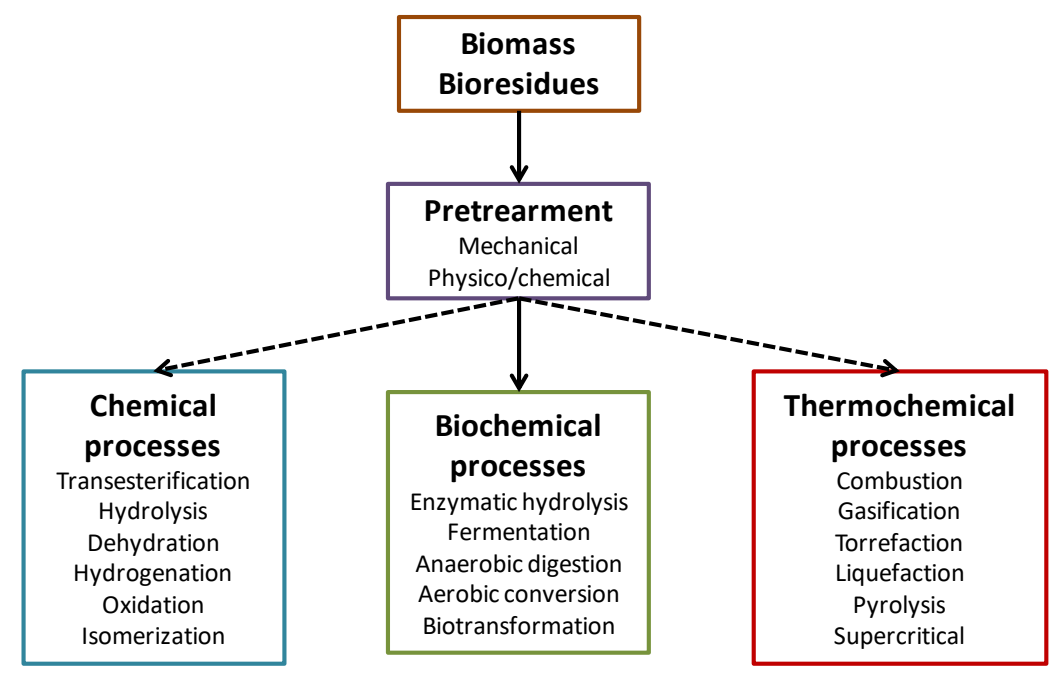

Figure 5. Valorisation routes of biomass and biomass-related wastes within biorefinery concept.

The biorefinery concept is analogous to the conventional concept of the petroleum refinery (Kamm and Kamm, 2004; de Jong and Jungmeier, 2015), i.e. "an installation where, through various processes of transformation of the raw material (biomass or biomass-related waste), bioenergy (heat, electricity, biofuels) and a broad spectrum of bioproducts (materials, chemicals, food and feed) are generated" (Figure 6). But to achieve this wide range of products requires the integration of different processes and technologies in the same facility (Budarin et al., 2011; Clark and Deswarte 2015). It is important to differentiate between what has 
traditionally been known as bio-industry and what is a biorefinery. Whereas in a bio-industry one or several bioproducts are produced, but not energy (beyond self-consumption in its own processes); in a biorefinery, in addition to bioproducts, biofuels and/or energy are produced. In addition, biorefining must imply a clear component of efficient use of resources, ensuring the sustainability of the overall process.

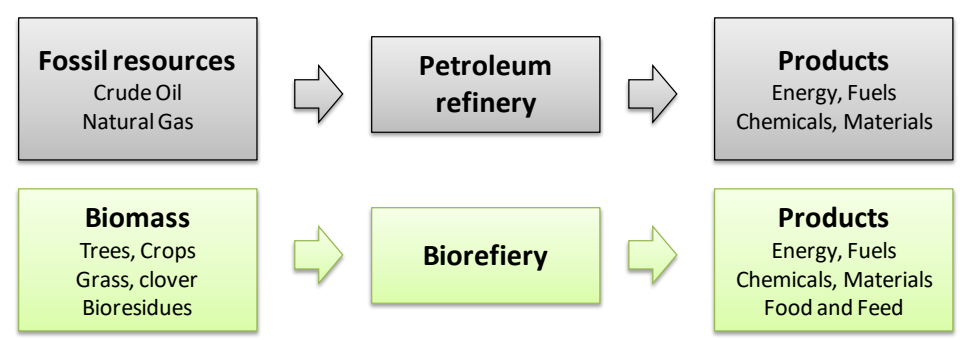

Figure 6. The biorefiney concept vs. petroleum biorefinery.

The concept of biorefinery is directly associated with biomass valorization processes. These processes will vary depending on the biomass used as raw material and the desired products, so that there will be different types of biorefinery according to these two concepts (Ferreira, 2017; Bastidas-Oyanedel and Schmidt, 2019). Generally speaking, it can be said that the overall process of a biorefinery essentially consists of the following phases shown in Figure 7: conditioning and preparation of the biomass, separation of its components (primary biorefinery processes) and the subsequent conversion and processing steps (secondary biorefinery processes). Intermediate products that originate during the primary processes that take place in a biorefinery are known as biorefinery platforms. These platforms serve as raw material for the secondary processes of the next stage (Corma et al., 2007). For this reason, the platform acquires a leading role in the overall system of the biorefinery concept. However, it is important to stress that not all the platforms identified represent a real possibility to be used in a secondary biorefinery process, for technological, economic or geographical reasons.

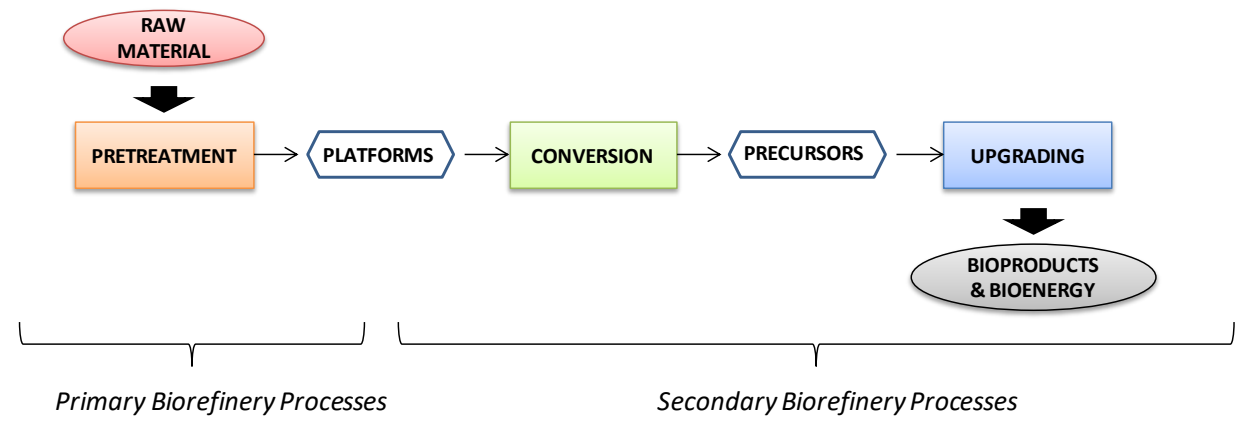

Figure 7. Scheme of the overall process of a biorefinery. 
The great diversity of existing biomass and the multitude of possibilities for its conversion multiply the possible operating schemes that can be developed in a biorefinery. This extensive variety makes it difficult to establish a single classification. Biorefineries are classified on the basis of various criteria that can be found in the extensive existing scientific literature (Cherubini et al., 2009; de Jong and Jungmeier, 2015; Castilla-Archilla et al., 2019) such as: degree of technological development (advanced vs. conventional biorefineries), type of biomass used (1st, 2nd and 3rd generation biorefineries), type of conversion process that prevails (e.g. thermochemical biorefineries) or complexity of the process of encompassing product development from various platforms (e.g. biorefineries with two platforms). The group of experts on biorefineries of the International Energy Agency (IEA Bioenergy Task 42) has chosen to classify them solely on the basis of the first three criteria mentioned above, i.e. according to the state of technology (implementation), the type of raw material used or the main type of conversion process used. Due to the wide variety available for the identification of types of biorefineries, the International Energy Agency's expert group on biorefineries has developed a biorefinery classification system, which is based on a schematic representation of the complete "biomass to end product" chains. Biorefineries, broadly speaking, can be divided into two types:

1) Energy-driven biorefinery. It is mainly oriented towards the production of one or several types of energy (heat and electricity) and/or biofuels. Bioproducts are also obtained that can be used for the production of chemical products, materials, food and feed.

2) Product-driven Biorefinery. It is mainly oriented towards the production of chemical products, materials, food and feed. Secondary products are often used for the production of intermediate energy vectors (electricity and heat) both for internal uses and for distribution in the market.

Therefore, due to the variety of possible systems within these two types of biorefineries, the International Energy Agency proposes to advance the classification of biorefineries by indicating the platforms involved, the products, the raw materials and, if necessary, the processes (Figure 8). An important characteristic of this classification approach is that it can be expanded to include future developments of biorefineries concerning new feedstocks, platforms, processes or products. That can be added to features of a specific element of a value chain or diversified options of a bio-based production value chain (Cherubini et al., 2009). A key factor in the realization of a successful bio-based economy will be the development of biorefinery systems that are well integrated into the existing infrastructure. 


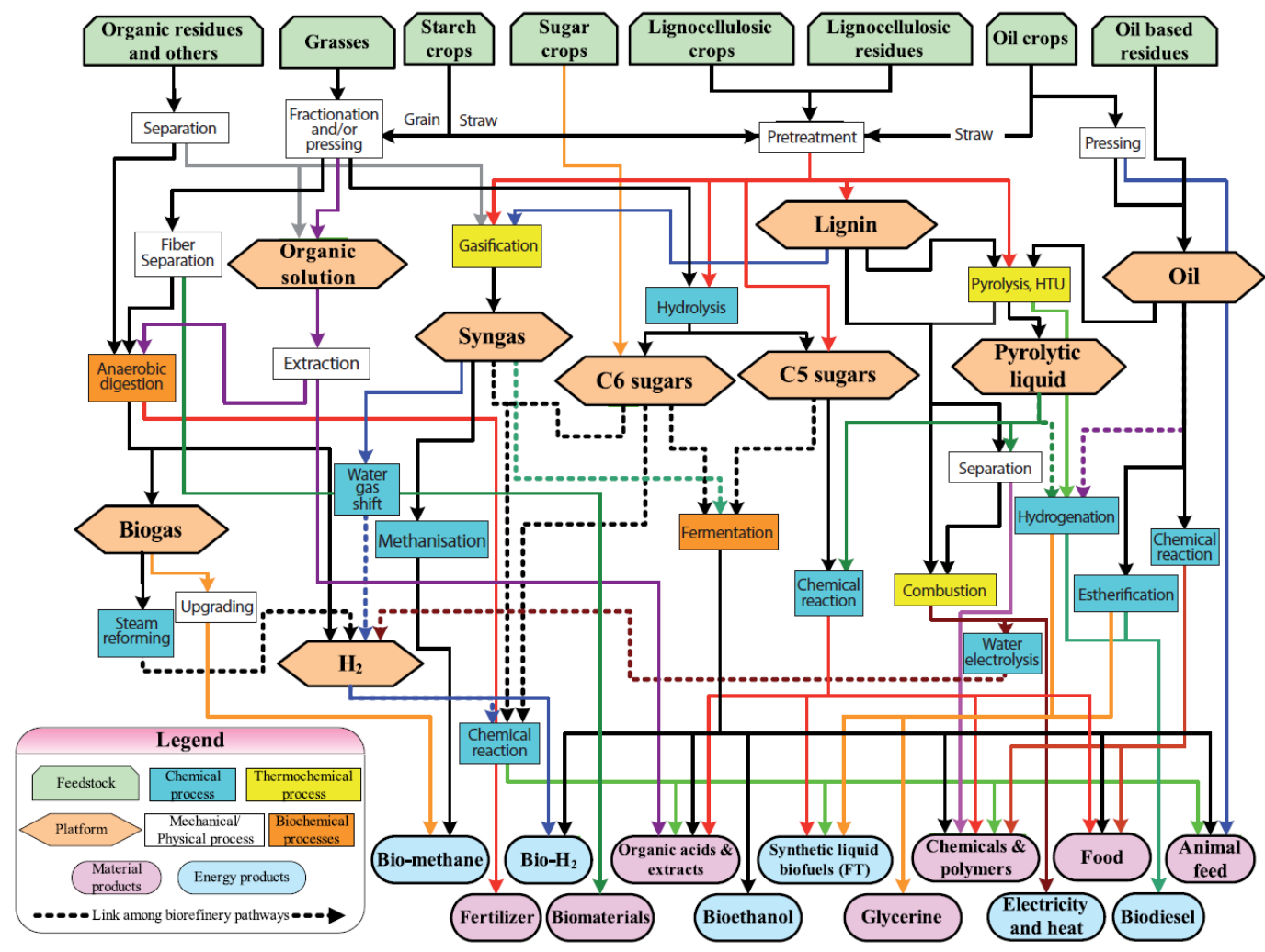

Figure 8. Network on which the biorefinery system is based (source: http://www.ieabioenergy.com).

The choice of biomass and final products is fundamental in biorefinery design due to the largescale production implications. "The global biorefinery market and development strategy includes both the substitution of existing products (also known as drop-in) and the obtaining of "new" products (also known as ex novo) with different or improved functionalities". In the short term the development is estimated to occur mostly in the drop-in niche (Huber et al., 2006; Bozel and Petersen, 2010). The main technological challenges facing the biorefinery concept involve logistical issues, developing catalysis (chemical and enzymatic), biotechnology, new processes (including separation and purification operations) and intensification, as well as their optimization and upscaling (Fernando et al., 2006; Pérez et al., 2017). In order to achieve commercial implementation of biorefineries, it would be necessary, among other things, to reduce the associated costs and increase the efficiency of conversions to bioenergy and bioproducts, a process closely linked to research and innovation. Moreover, "the modification of certain public policies is considered an essential impulse for the development of biorefineries, going one step further than the incentives that the use of biomass for the generation of energy, biofuels and bioliquids has been relying on" (Peck et al., 2009; Mohan, 2016). In any case, a public strategy is required to encourage the integral use of biomass and the biorefineries development towards bio-based economy (Hellsmark and Söderholm, 2017). 


\section{Renewable resources towards circular bio-based economy}

Bioeconomy contributes to a great extent by placing the bioenergy or biocommodity chemicals in the present energy and industrial sectors with simultaneous reduction on the load of fossils. Hence, the conversion of renewable biomass to biofuels, chemicals and biomaterials in integrated biorefineries forms the basis of a carbon neutral, bio-based economy (Figure 9). "The term 'bio-based' refers to the use of renewable biomass as the raw material rather than the technology used for its conversion, which can involve chemical or biotechnological processing" (Cherubini, 2010).

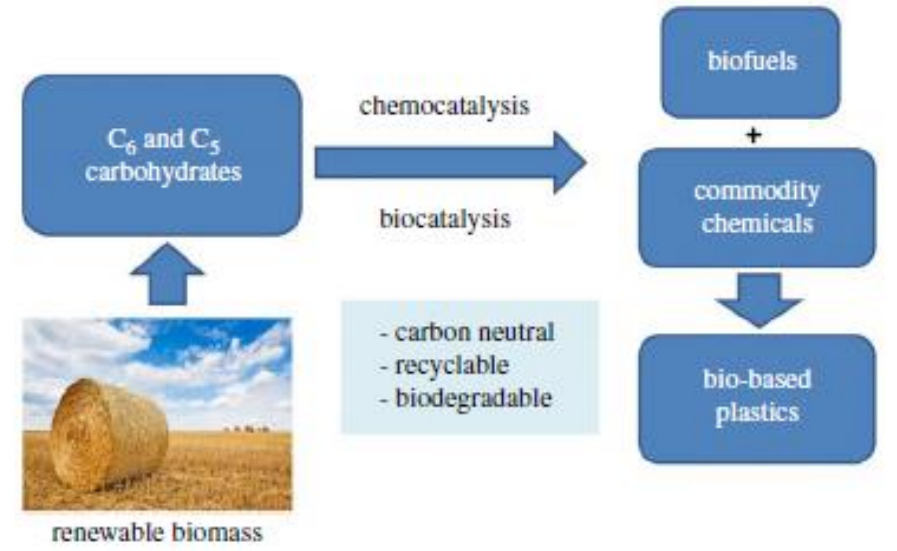

Figure 9. The bio-based economy (Sheldon, 2020).

Renewable biomass consists primarily of carbohydrates which can be divided into storage polysaccharides, such as starch and inulin and the disaccharide, sucrose, which comprise first generation biomass including edible triglycerides, and structural polysaccharides exemplified by (ligno)cellulose, hemicellulose, pectin and chitin which constitute second generation feedstocks. Aquatic carbohydrates, derived from micro- and macro-algae, consist of a variety of polysaccharides that differ in structure from their terrestrial counterparts and are potential feedstocks for third generation biorefineries. Figure 10 shows a scheme for this classification. Currently, the bio-based economy is based almost exclusively on first generation feedstocks which can relatively easily be depolymerized hydrolytically to glucose which is further converted to biofuels, mainly bioethanol, and commodity chemicals. Most commercial or first generation biorefineries used sugarcane, corn, or soybeans to produce value-added products for feed and food applications and fuel ethanol and specialty chemicals (Hossain et al., 2017). These provide good examples of how traditional agricultural processing companies operated in 
the past several decades and are gradually transforming into a fully integrated biorefinery industry with an expanded product portfolio with more fuels and chemicals, often partnering with large chemical and oil companies. Almost all current biofuels (mainly ethanol, butanol, and biodiesel) and bio-based chemicals (lactic acid, itaconic acid, 1,3-propanediol, etc.) are produced in this type of biorefinery. The major producers are the United States with $56 \%$ consisting of corn starch-based ethanol and Brazil with $28 \%$ sucrose-based ethanol and the EU with a paltry $5 \%$ mainly from wheat starch in 2018 , leaving $11 \%$ for the rest of the world (https://ethanolrfa.org/statistics/). However, the use of starch from corn and wheat and sucrose from sugar cane and beet, and triglycerides from edible oil seeds are not perceived as sustainable options in the longer term because of competition, directly or indirectly, with food production. Some organic waste in the form of lignocellulose, such as agricultural and forestry residues, is unavoidable and this waste constitutes a suitable feedstock for valorization in integrated biorefineries (Tuck et al., 2012). In the European Union emphasis is, therefore, firmly on the use of second generation biomass, comprising waste lignocellulose and waste oils and fats as feedstocks, for the future production of biofuels and commodity chemicals.

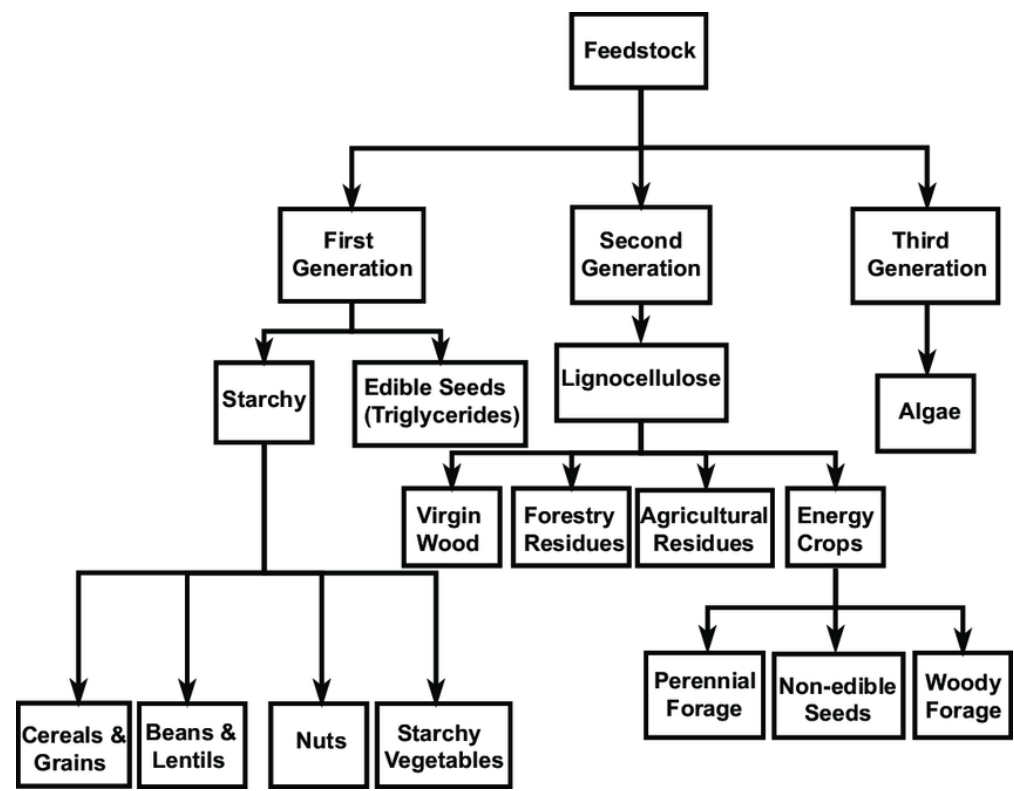

Figure 10. Classification of biomass feedstock in three generations (Bardhan et al., 2015).

In general, modern lignocellulosic biorefineries are composed of three main sections: thermochemical pretreatment, enzymatic hydrolysis, and sugar fermentation to fuels (Hossain et al., 2017). Interestingly, lignocellulose waste is formed as inevitable waste in the production of both food and first generation feedstocks. In the latter case, there is much to be gained from conversion, for example of both the sugar and the sugar cane bagasse or sugar beet pulp, 
or both the cassava starch and cassava pulp (Sánchez et al., 2017) in what is sometimes called 1.5 generation biomass processing. For example, global production of lignocellulosic waste in the form of sugar cane bagasse, corn stover, wheat straw and rice straw amounts to hundreds of millions of tonnes per annum (Saini et al., 2015) and far exceeds the annual production of the top petrochemicals, ethylene, propylene and para-xylene that accounts for almost 300 million tonnes. Conversion of this waste to value-added products is at the heart of a bio-based circular economy (Clark, 2017; Mohan et al., 2016; Ligouri and Faraco, 2016).

More generally, biomass is a combination of naturally derived materials originating from plants as well as all the materials composed of organic matrix except for plastics originating from petrochemical materials (McKendry, 2002). In the bioeconomy context, "biomass comprises the renewable biological resources for the conversion of these resources and waste streams into value-added products such as food, feed, bio-based products, and bioenergy" (European Commission, 2012). Thus, it includes edible (food) and non-edible (non-food) biomass from plants, animals, and waste origin (Figure 11). Obtaining chemicals from waste is a possible alternative to petroleum products and an opportunity to apply technologies for resource efficiency (Nizami et al., 2017; Clark, 2019). The use of industrial wastes such as rubber and mining wastes, agro-food, forestry and urban waste as raw material for useful chemical products and bioenergy is far from being a generalized activity (Haddadi et al., 2018; Caldeira et al., 2020). In particular, this thesis is mainly focused in the development of sustainable processes for the production of bio-based chemicals and polymers. The origin of the bioresources selected for this purpose includes agricultural residues (non-food crops), industrial residues (biofuel by-products and food processing waste) and municipal solid waste.

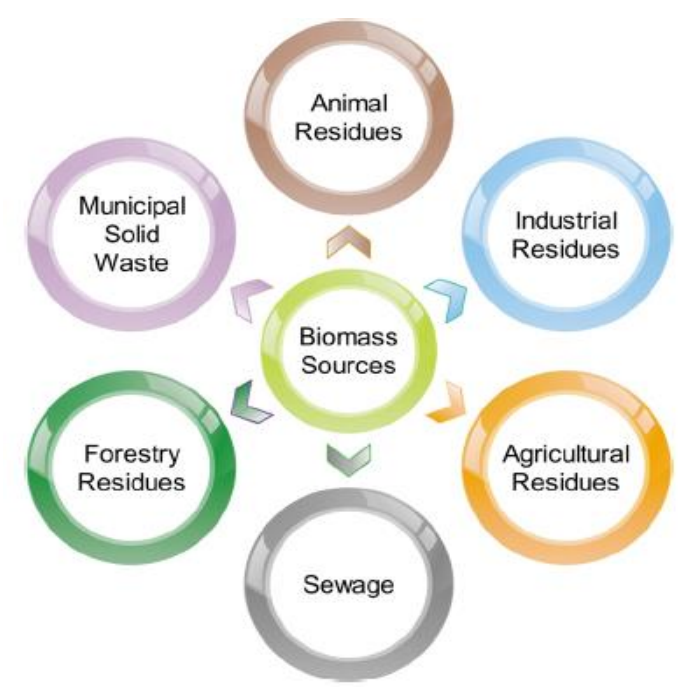

Figure 11. The most important biomass sources (Tursi, 2019). 
In one hand, the contribution of oil crops to bioenergy is framed within the sector of biodiesel, which is currently produced by transesterification or hydro-treatment of vegetable oils. Though oil seeds like palm, sunflower, rapeseed and canola have mostly been used for the production of biofuels, several value added chemicals and enzymes can also be produced from the cake residue (Muralidhararao et al. 2007; Chang et al., 2014), or even, non-edible oils could be used as feedstock for the production of renewable chemicals (Sainger et al., 2017). In adition, crude glycerol is the main by-product of the biodiesel industry that contains $77-90 \%$ glycerol (Koutinas et al., 2014), and this situation encouraged development of glycerol conversion technologies. The biodiesel production accounts for 9.8 million tonnes in EU and around $1 \mathrm{~kg}$ of glycerol is produced per $10 \mathrm{~kg}$ biodiesel (Quispe et al., 2013). Glycerol can be used as an inexpensive feedstock for the production of reduced chemicals including succinic acid and 1,3-propanediol by microbial fermentation (Posada et al., 2012).

In the other hand, the enormous amounts of food supply chain waste (Pfaltzgraff et al., 2013), formed in the harvesting, processing and use of agricultural products in food and beverages is largely unavoidable but can be converted to value-added products in food waste biorefineries (Carmona-Cabello et al., 2018; Dahiya et al., 2018). The main waste generated from the dairy sector is whey, resulting from the protein coagulation in milk during cheese production. Cheese whey constitutes one of the most polluting by-products; due to its high organic load (proteins, lactose, and salts). Hence, a large number of valorization approaches have been reported; mainly targeting the recovery of proteins and lactose for further exploitation as renewable resources (Lappa et al., 2019). Regarding beverage industry, the solid side streams produced from the juice production process of fruit and vegetables represents $30-50 \%$ of the initial raw material and the composition varies depending on the fruit used as raw material. Assuming that $60 \%$ of the produced juice comes from oranges (35\%) and apples (25\%), seeds and peels enclose a significant amount of essential oils rich in bioactive compounds that can be directly extracted as value-added products via various technologies. Fruit processing wastes can also be used as substrate to support microbial fermentations for bioconverting their carbohydrate content to bioproducts (Gullon et al., 2008; Patsalou et al., 2017).

Finally, around 250 billion tonnes per year of municipal solid waste are generated in EU which contains around $30 \%$ organic fraction. Even if half of the estimated quantities are considered as raw material for biogas and compost production, the remaining quantities are still sufficient for the development of many biorefinery plants for biofuels and bio-based chemicals production via fermentation and other bioconversion processes (Caldeira et al., 2020). 


\section{Industrial Biotechnology, Biocatalysis and Biomass conversion}

Industrial Biotechnology, also known as White Biotechnology, is the modern use and application of biotechnology for the sustainable production and processing of fuels, materials and chemicals (Wenda et al., 2011; Heux et al., 2015; Hossain et al., 2017). The main objective of industrial biotechnology is the search for more efficient and environmentally sustainable production mechanisms, including feedstock pretreatment and hydrolysis stages, and fermentation processes depending on the starting platforms and products of interest as shown in Figure 12 (Erickson et al., 2012; Sheldon, 2020). These objectives can be achieved by developing better biological catalysts, creating the best possible environment for each reaction and improving the final stages of production (separation, purification and subsequent chemical conversion of the desired products) through biochemical process engineering. Thus, the optimisation of the operating conditions in the bioreactors, the upscaling of the bioprocesses and the procedures for isolation and purification of the bioproducts is as important as the development of new biocatalysts. Advances in this area are focused on the design of new bioreactors, new fermentation configurations and technologies (stage integration, continuous fermentation, etc.), and new bioproduct separation processes (Jovanic, 2006; Vertès et al., 2007; Larroche et al., 2017). Also of special interest is the study of control systems that allow continuous monitoring of the processes (Rudnitskaya and Legin, 2008).

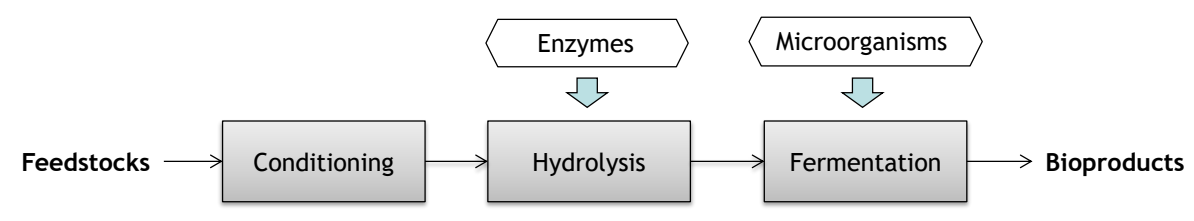

Figure 12. Biocatalysts (enzymes and microorganisms) for industrial bioprocesses development.

As far as biosynthesis is concerned, biocatalysis encompasses those production processes that use both whole organisms and isolated enzymatic systems, whether free or immobilized (Sheldon, 2020). Biocatalysts are used to manufacture products in sectors such as the chemical, agro-food, paper, textile and energy sectors (Prasad and Roy, 2018; loannidoua et al., 2020). The use of biocatalysts is a sustainable alternative to traditional chemical synthesis, as it uses gentler reaction conditions and has lower energy requirements (Alcalde et al., 2006; Ahmann and Dorgan, 2007). In addition, biocatalysts are biodegradable and have chemical selectivity, which reduces the formation of by-products and the need to activate, deactivate and/or protect functional groups of the reagents (de Gonzalo and de María, 2017). Through 
genetic engineering techniques (overexpression, delection and/or introduction of genes of interest) and physiological engineering (cultivation and adaptation of the catalysts to the appropriate process conditions), it is possible to develop and obtain new strains and enzymes (Stephanopoulus, 2007; Buschke et al., 2013; de Gonzalo and de María, 2017).

The selection of biomass feedstock and biocatalysts capable of utilizing biomass as a substrate is crucial for establishing biorefinery systems and is achieved together with the application of environmental biotechnology (Petre, 2013; Amoah et al., 2019). After the appropriate mechanical or physicochemical pre-treatment (Taherzadeh and Karimi, 2008; Ravindran and Jaiswal, 2016) the biomass can be fractionated by enzymatic hydrolysis using industrially important enzymes including lipases, amylases, cellulases and proteases which can be used for the release of fatty acids, sugars and amino acids depending on the starting raw material, and carrying out other green processes (Bharathiraja et al., 2017; Prasad and Roy 2018). The prohibitively expensive enzyme in enzymatic hydrolysis is one of the largest contributors to the overall cost of biofuel and biochemical production from biomass and biowaste (Singh et al., 2019; Caldeira et al., 2020). Reducing the cost associated with the use of enzymes is prudent in making enzymatic hydrolysis more economically feasible. To achieve this, several approaches including substrate and enzyme-related approaches have been evaluated (Velasco et al., 2017; Guo et al., 2018). By supplementing cellulase with accessory enzymes (enzyme cocktails), this approach has shown significant improvements in reducing the total enzyme load for biomass hydrolysis (Berlin et al., 2006; Gao et al., 2011; Raghavendra et al., 2016).

In the other hand, fermentation can be considered in a simplified way as a biological process by which a substrate is converted into cell biomass, energy for the microorganism and other products. The science and engineering of fermentation forms the working basis of most bioprocess industries, as well as those industrial sectors that make use of one or a few bioprocessing steps in their processes (Kawaguchi et al., 2017; loannidoua et al., 2020). Microbial platforms such as Escherichia coli, actinomycetes, corynebacterium, yeast, fungi, lactic acid bacteria are well known to produce some important biochemicals (Figure 13). Recent advances in genetic engineering technologies, such as the discovery of the CRISPRCas9 system and approaches, offer a great opportunity to explore the biotechnological potential of microorganisms (Lin et al., 2019; Ma et al., 2020). Microbial screening processes are required for the selection of microbes for targeted products from the feedstock of interest. It is comparatively easy to screen from a group of microbial sources that have been already systematically identified. The role of culture collection is therefore crucial for utilizing microbes 
in the fermentation of biomass and biomass-related wastes (Amoah et al., 2019). In any case, every biotechnological application oriented to the development of biorefineries makes use of the so-called "x-omic" sciences: genomics, metagenomics, transcriptomics, proteomics, metabolomics and analysis of metabolic flows (Heux et al., 2015; Fayyaz et al., 2020). The information provided by these sciences is stored and interpreted through the use of bioinformatics which in turn provides the tools for systems biology, based mainly on modelling, and for synthetic biology, to re-design microorganisms for the optimisation of biocatalytic processes of interest in a biorefinery (Keasling, 2008; Jullesson et al., 2015).

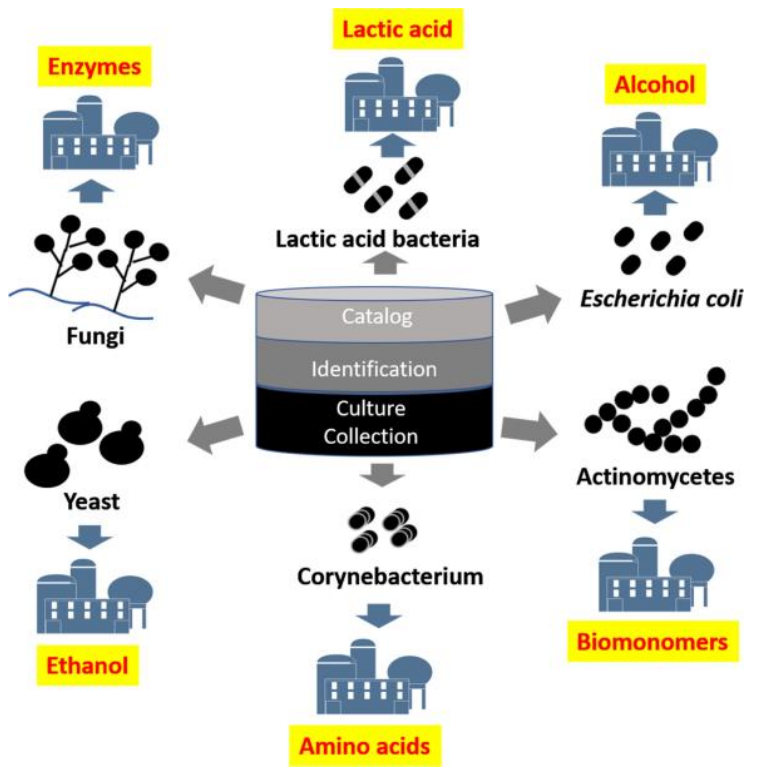

Figure 13. Industrial microorganisms for industrial bioprocesses in biorefinery (Amoah et al., 2019).

The contribution of biotechnology to the development of the concept of biorefinery is fundamental, but so is that of other technologies (chemistry, engineering...), which must be integrated as a whole in order to maximize their efficiency and competitiveness (Erickson et al., 2012; Larroche et al., 2017). In recent years, research into the improvement of biomass biotransformation processes was focused on the development of mixed cultures applicable in anaerobic digestion processes (Jiang et al., 2017; Moscoviz et al., 2018; Strazzera et al., 2018), the search for thermophilic microorganisms and thermostable enzymes applicable in simultaneous hydrolysis and fermentation processes (Patel et al., 2019; Sharma et al., 2019), the use of microorganisms producing enzymatic mixtures with industrial application (Guo et al., 2018; Prasad and Roy, 2018), the manipulation of the metabolism of microorganisms towards the synthesis of target products (i.e., alcohols, organic acis, etc.) in high concentration (Buschke et al., 2013; Heux et al., 2015; Gustavsson and Lee, 2016), among others. 


\section{Bio-based chemicals and polymers for sustainable development}

The intensive use of mineral resources (oil, coal, gas) results in their significant depletion but also brings a negative contribution to climate changes on the planet. Transition to the use of renewable resources would allow to decrease the greenhouse effect and to reduce carbon dioxide emissions to the atmosphere by bringing into balance the "carbon cycle". The carbon cycle is the most important cycle of our ecosystem and it is balanced in the absence of influence of human activity. Interference of man by introduction of mineral (fossil) resources into the carbon cycle leads to imbalance. Thus "fossil sourced" carbon dioxide, that used to be in the form of immobilized mineral resources, enters the carbon cycle. Hence it accumulates in the atmosphere, causing the "green house effect" leading to global climate changes. Polymers and plastics are almost entirely based on fossil resources. Most plastics or petrochemical based polymers exhibit poor biodegradability and represent a challenge for their disposal and subsequent landfilling (Johansson et al., 2012). In 2015, Europeans generated around 16 million tonnes of plastic packaging waste (Eurostat 2015). The adoption of biopolymer alternatives to petroleum-based plastics potentially reduced carbon dioxide emissions by $30 \%$ to $70 \%$ (Lackner, 2015). Therefore, the use of sustainable polymeric materials derived from biomass resources is believed to contribute to the preservation of natural resources and protection of the global environment because of its "carbon offset" or "carbon neutral" nature. In 2019, the total production volume of bio-based polymers was 3.8 millon tonnes, which is $1 \%$ of the production volume of fossil based polymers and about $3 \%$ more than in 2018 (Figure 14). These bio-based polymers can replace the conventional polymeric materials that are synthesized from fossil resources (Kimura, 2009), and thus, they can be renewable and sustainable in terms of long-range production and consumption

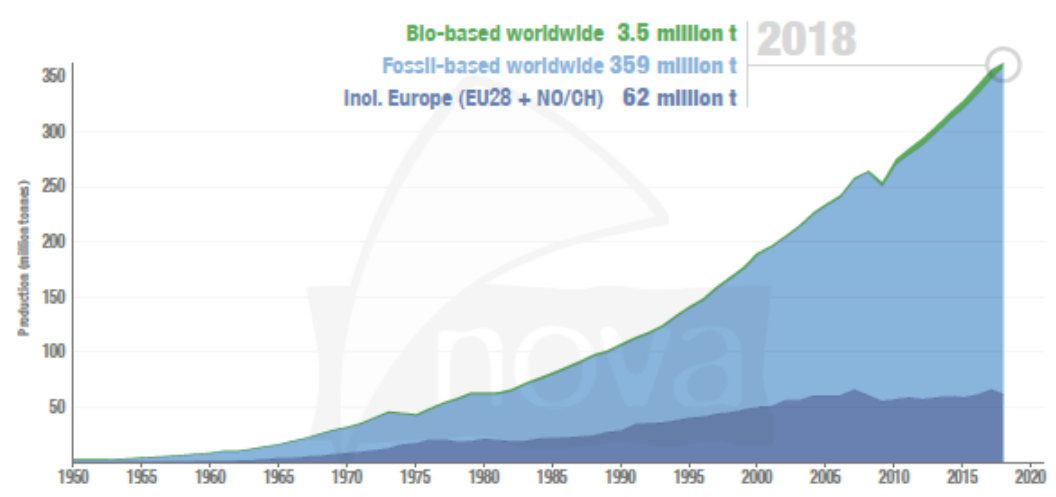

Figure 14. Plastics production from 1950 to 2018 (source: http://bio-based.eu/markets). 
Bio-based polymers are generally divided into two classes as shown in Figure 15: natural polymers and synthetic polymers depending on the synthetic processes or what type of monomers is utilized (Masutani and Kimura, 2015).
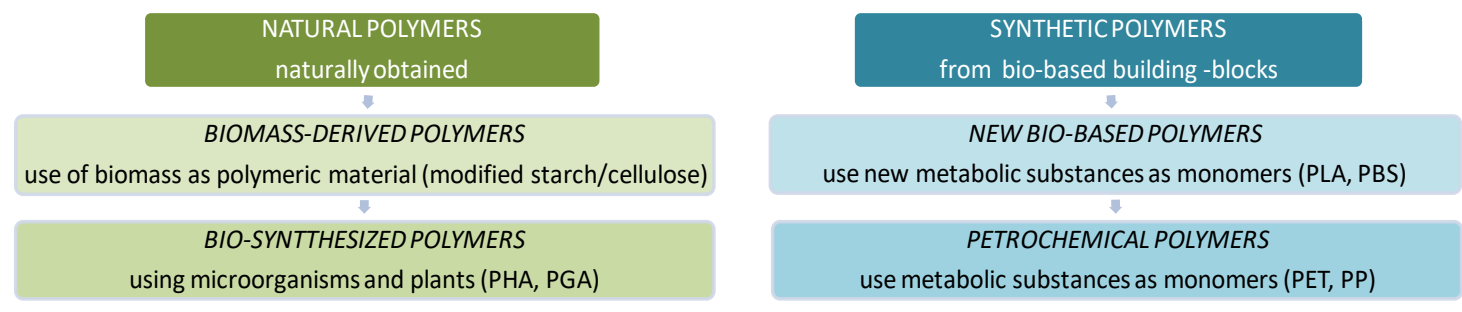

Figure 15. Classification of bio-based polymers.

Considering the future steady increase of bio-based polymers, the biomass feedstock requirement is a necessary factor to consider. Polymers can be produced from various renewable resources. Currently resources most used for this purpose are products and byproducts from the agricultural sector that are rich in carbohydrates - especially saccharides, such as grain, sugar beet, sugar cane, etc. As mentioned in the previous section, all current research in the development of bio-based materials focuses on sustainable bio-resources i.e., non food and feed renewable resources and waste resources such as lingo-cellulosic resources, agricultural waste, food waste, etc. Products such as Corn are human food and scale up of the industry based on raw materials that compete with food uses is impractical. Therefore, a switch over to non-food sources of biomass, rather than starches, sugars, or food oils, is badly needed. Using local excess or waste biomass as feedstock will result in a sustainable source of plastics, based on conventional life cycle analysis calculations. In any event, using regionally available biomass resources that rely on existing supply chains is advantageous. It can reduce costs and create a less volatile price of raw materials, reduce market complexity, and even provide local employment. Figure 16 shows the percentage distribution of the 5 million tones biomass needed for worldwide production of 3.6 million tonnes of bio-based polymers. The major biomass feedstocks used for bio-based polymer production are biogenic by-products $(46 \%)$, especially the by-product glycerol from the biodiesel production, which is mainly used for epoxy resin production. From the 3.6 million tonnes of produced bio-based polymers only 1.6 million tonnes are actual bio-based parts of the polymers (43\%). Considering this fact, 3 times more feedstock is needed than used for product formation. This amount of over 3.4 million tonnes $(68 \%)$ of feedstock that is not ending up in the product is due to high number of conversion steps and related feedstock and intermediate losses. 


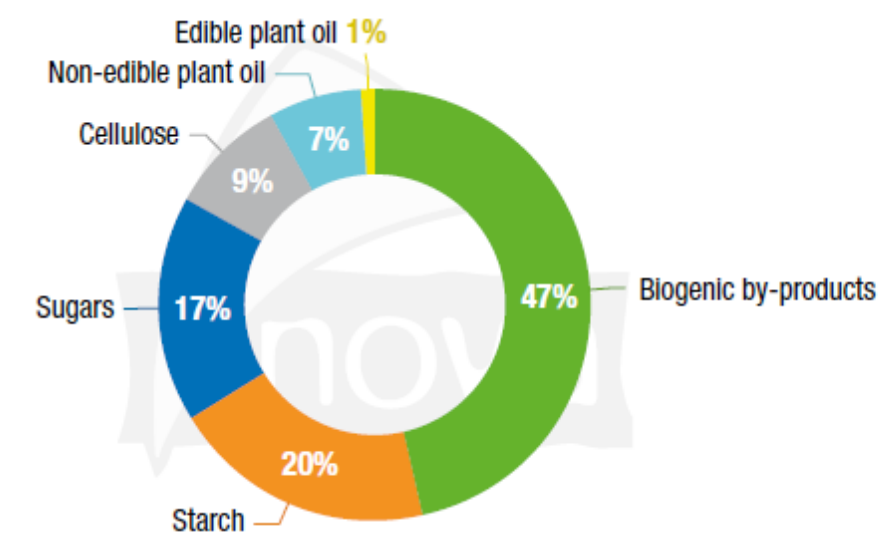

Figure 16. Worldwide biomass requirement for bio-based polymer production in 2019 (source: http://bio-based.eu/markets).

The global polymer market includes functional and structural polymers, rubber products as well as man-made fibres. The chemical production chain has different pathways of drop-in, smart drop-in and dedicated bio-based chemicals and polymers. While drop-ins have direct fossil-based counterparts (i.e., polyethylene terephthalate and polypropylene) and can substitute them, the dedicated ones have new properties and functionalities that petrochemistry does not provide (i.e., polylactic acid and polyhydroxyalkanoates). The different bio-based polymers groups are subject to different market dynamics and the most dynamic development is foreseen for drop-in biopolymers. The building blocks are utilized for the synthesis of structural and functional polymers as well as ingredients in various other applications such as food, feed, cosmetics or pharmaceuticals. The main results reported in 2020 by Nova Institute (http://bio-based.eu/markets) indicate an expected compound annual growth rate of about 3\% for bio-based polymers (Figure 17) and $5 \%$ for bio-based building blocks (Figure 18). After Asia as the leading region, Europe displays the highest growth of biobased polymer capacities expected between 2019 and 2024.
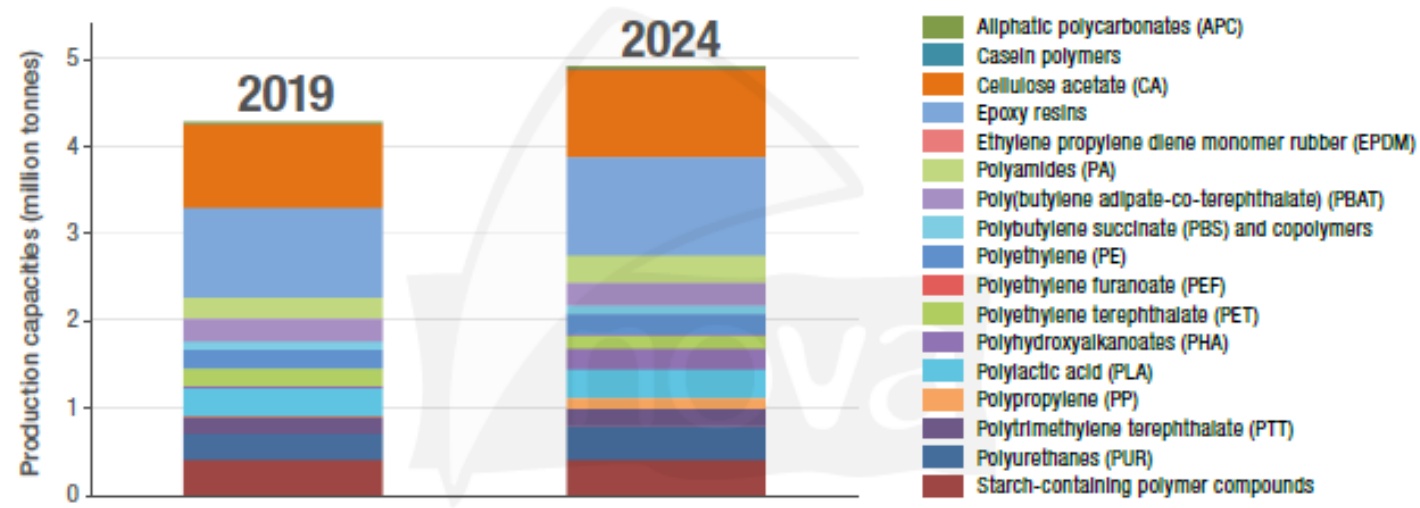

Figure 17. Bio-based polymers production capacities in 2019 (source: http://bio-based.eu/markets). 


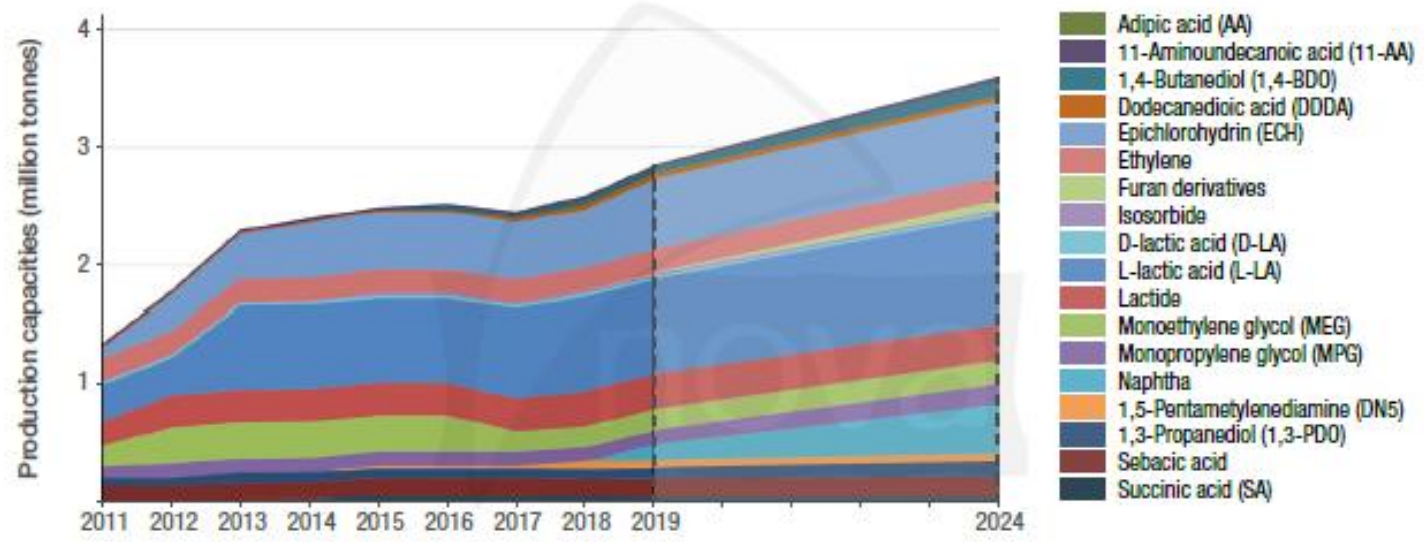

Figure 18. Bio-based building blocks evolution of worldwide production capacities from 2011 and 2024 (source: http://bio-based.eu/markets).

Today, bio-based polymer can be used in almost all market segments and applications, but the application per polymer are very different. The European bioeconomy aims to activate the potential of bio-based products and generate new markets and industries while enhancing the sustainability of production and consumption (European commission 2012). Bioplastics are an important part of the bioeconomy and will shape the future of the plastics sector. The definition of bioplastics includes either of the following two basic criteria: its origin from renewable raw materials (biomass) and/or its biodegradability. Figure 19 presents this classification schematically. There may be bioplastics that come from biomass and are not biodegradable and, on the contrary, bioplastics derived from petroleum that are biodegradable; which is why it is vitally important to distinguish them correctly. Bioplastics have the same properties as conventional plastics but can offer additional advantages.

Regarding their production process, industrial biotechnology can intervene in the production of bioplastics in two ways: one is by providing the monomers (also called building-blocks) required for the synthesis of bioplastics, the polymerization of which is subsequently carried out by means of chemical-type technologies. The polymerizable monomers can be obtained by biotechnological means (fermentation) either directly or in the form of precursors that require a simple chemical transformation for their use. This group includes lactic acid, succinic acid, adipic acid, 3-hydroxypropionic acid, and 1,3-propanediol, among others. The other way in which industrial biotechnology can intervene in the production of bioplastics consists in the integral synthesis of them, from a renewable raw material to the final biopolymer, by means of biotechnological processes, mainly by microbial fermentation. This group includes, for example, polyhydroxyalkanoates and polyglutamic acid (also called natural polymers). 


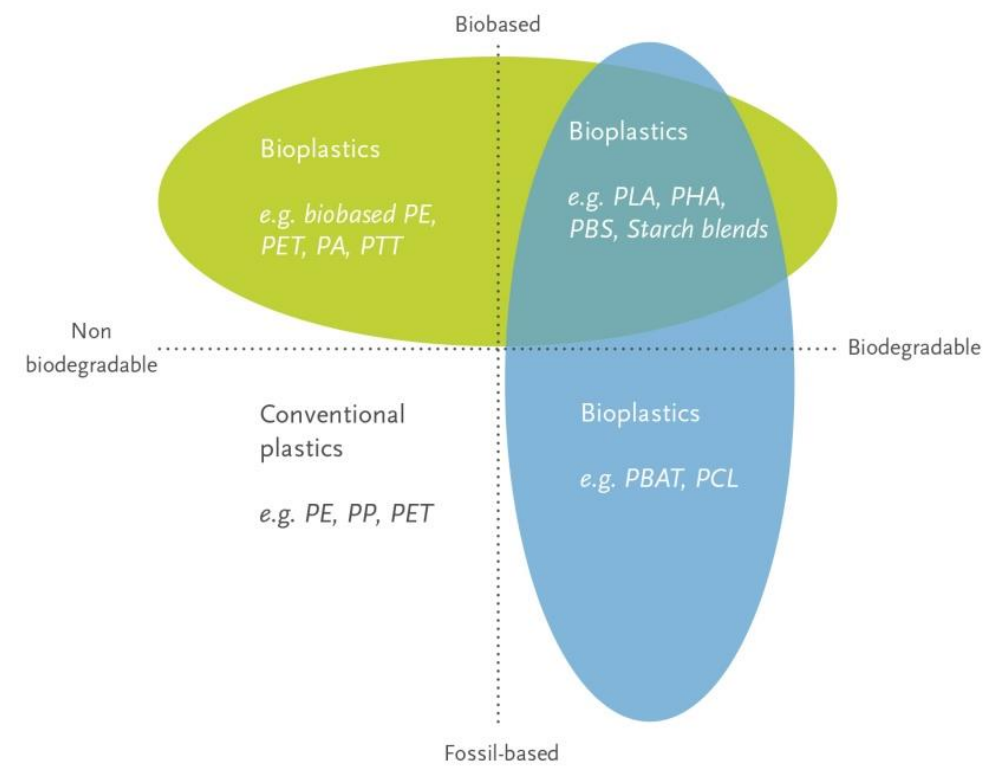

Figure 19. Classification of bioplastics (source: http://www.european-bioplastics.org).

According to the market data compiled by European Bioplastics in cooperation with the research institute nova-Institute (https://www.european-bioplastics.org/market/), global bioplastics production capacity is set to increase from around 2.11 million tonnes in 2019 to approximately 2.43 million tonnes in 2024. New and innovative biopolymers, such as bio-based polypropylene (PP) and polyhydroxyalkanoate (PHA) show the highest relative growth rates (Figure 20). Bio-based, non-biodegradable plastics altogether, currently make up for over $44 \%$ of the global bioplastics production capacities. In turn, biodegradable plastics altogether, account for over $55.5 \%$ of the global bioplastics production capacities. The production of biodegradable plastics is expected to increase to 1.33 million in 2024 especially due to PHA significant growth rates.
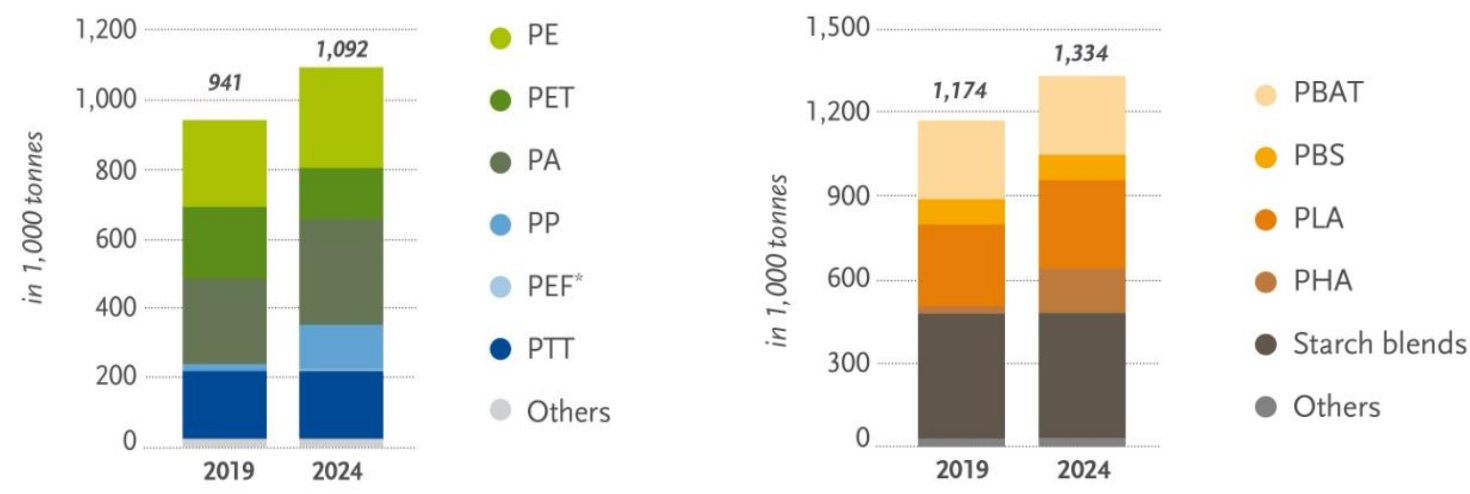

"PEF is currently in development and predicted to be available in commercial scale in 2023.

Figure 20. Production capacities of bioplastics 2019 vs. 2024. Bio-based and durable plastics (left) and Biodegradable plastics (right) (source: http://www.european-bioplastics.org). 
Bioplastics are used in an increasing number of markets as shown in Figure 21. Packaging remains the largest field of application for bioplastics. However, the portfolio of application continues to diversify. Segments, such as automotives and transport or building and construction, significantly increased their share. The increase in the use of bioplastics in all market segments is driven by the continuously increasing demand for sustainable products by consumers and brands alike. This is due to a growing awareness of the impact on the environment and the need to reduce the dependency on fossil resources as well as the continuous advancements and innovations of the bioplastics industry in new materials with improved properties and new functionalities. With a growing number of materials, applications, and products, the number of manufacturers, converters, and end users also increases steadily. Significant financial investments have been made into production and marketing to guide and accompany this development.

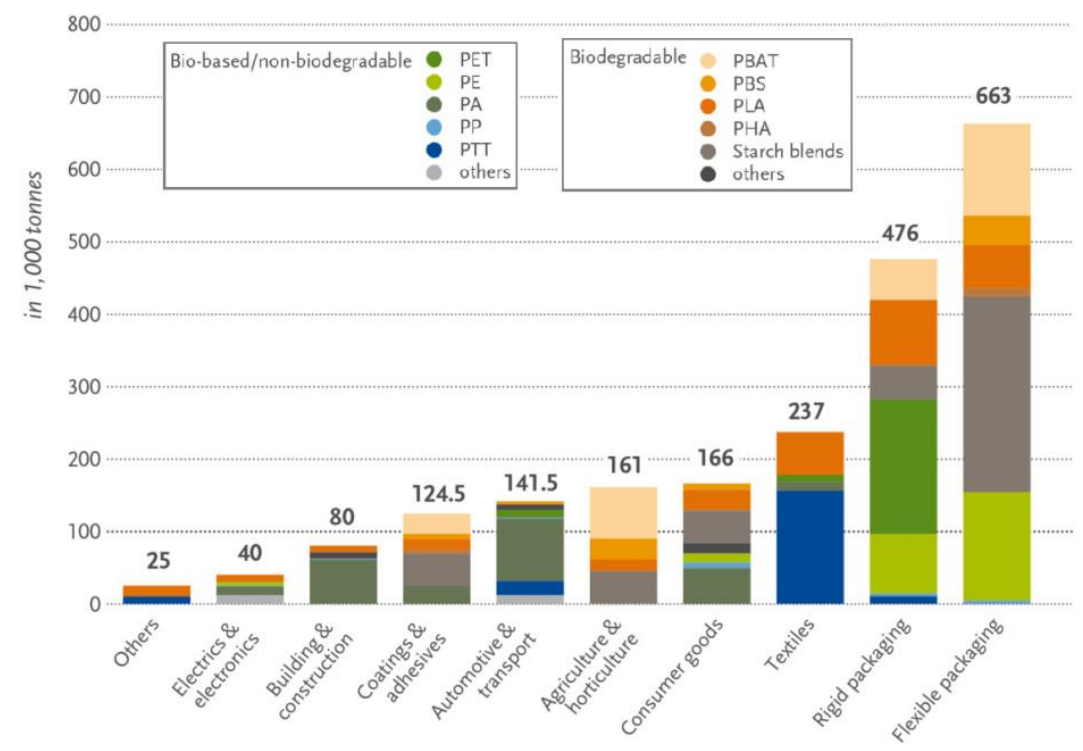

Figure 21. Global production capacities of bioplastics 2019 by market segment (source: http://www.european-bioplastics.org).

Regarding the political framework, 2019 was an important year for the bioplastics industry. Especially, the adoption of the Single-Use Plastics Directive and, at the end of the year, the publication of the new EU Commission's European Green Deal led to a strong dynamic, which was even intensify in 2020. As a result, main aspects of the European legal framework for plastics are currently under revision. This provides new opportunities for the role bioplastics can play in achieving a resource-efficient, low-carbon circular economy pursued by the European Union. Europe strengthened its position as a major hub for the entire bioplastics industry once again; it ranks highest in the field of research and development and is the 
industry's largest market worldwide. By now, one fourth of the global bioplastics production capacity is located in Europe. However, with a view to the actual production of bioplastics and regional capacity development, Asia continues to be the major production hub $(45 \%$ of bioplastics were produced in Asia in 2019) and the production in the Americas has also increased. Finally, the land used to grow the renewable feedstock for the production of bioplastics amounted to approximately 0.79 million hectares in 2019 (Figure 22), which accounted for less than $0.02 \%$ of the global agricultural area of 4.8 billion hectares, $94 \%$ of which were used for pasture (68\%), feed and food (26\%). Despite the market growth predicted in the next five years, the land use share for bioplastics will remain around $0.02 \%$ and this clearly shows that there is no competition with the renewable feedstock for food and feed.

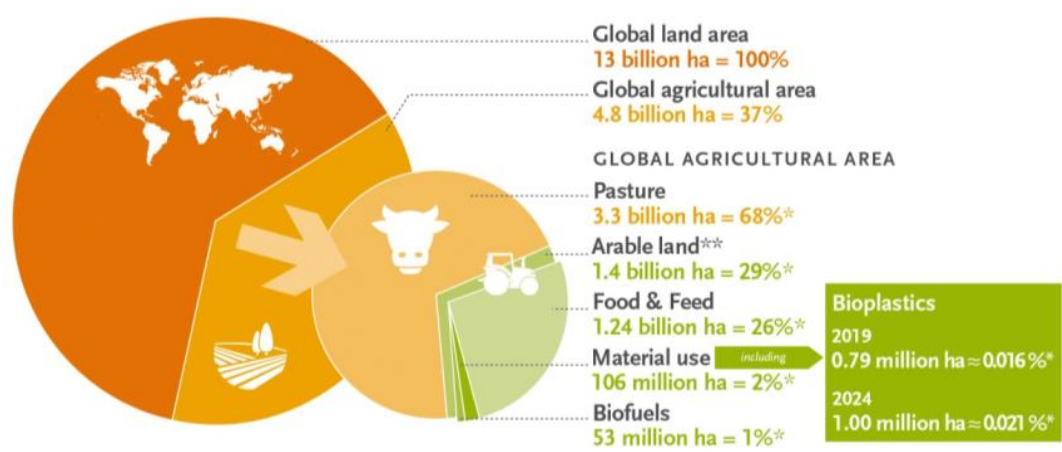

Figure 22. Land use estimation for bioplastics (source: https://www.european-bioplastics.org).

At this point and to conclude, the definition of sustainable chemicals and polymers should be considered at a system level, encompassing considerations such as the resources from which they are made, the manner in which they are produced, stored, distributed, utilized, and either recovered or otherwise released into the environment. Examples of bio-based products that have considerable potential and have been selected for this dissertation are listed as follows:

Polyhydroxyalcanoates (PHA) are polyesters produced by various archaea and Gram-positive and Gram-negative bacteria. PHA granules are stored in the cellular cytoplasm and act as reserve cytoplasmic inclusions under excess carbon source and/or nutrient limitions. These biopolymers are considered as an alternative to petroleum-based plastics because they are biodegradable in nature and can therefore be recycled (Gao et al., 2011). PHAs are completely biodegradable in soil and marine environments (UNE EN 13432:2000; ASTM 5988,6691) and have mechanical and thermal properties comparable to polyolefins (Solaiman et al., 2006). However, the production costs of PHA are higher than those of non-biodegradable synthetic plastics and accounts of around 3-4 Euro per kilogram. 
Lactic acid (LA) is produced industrially by fermentation, at a price of around 1-1.5 Euro per tonne and with a market volume of 300-400 million tonnes per year in very strong growth (19$22 \%)$. It is used as an additive and preservative in the food industry, but also as a solvent and precursor of polymers such as polylactic acid (PLA) in the chemical industry. The production of D-LA has emerged as particularly attractive due to its interest in the formulation of PLA with improved properties (Okano et al., 2010). The chemical synthesis of LA is based on the hydrolysis of lactonitrile by strong acids, but gives rise to racemic mixing. Therefore, the biotechnological synthesis offers advantages in comparison: low temperatures and low energy consumption, but the main advantage is the product specificity, since the desired enantiomer (L- or D-LA) can be obtained (John et al., 2007).

2,3-butanediol (2,3-BD) is a very promising compound both as a base chemical and as a liquid fuel. As a chemical reagent, its unusual stereochemistry is very useful. It has 3 stereoisomers: the dextro, levo and meso forms; and all three are produced by microbial fermentation. The levo isomer has a freezing temperature of $-60^{\circ} \mathrm{C}$, which makes it commercially interesting as antifreeze. Both the levo and dextro isomers are excellent chiral components for asymmetric synthesis and are used in the pharmaceutical, agrochemical, fine and food chemical industries, and as liquid crystals. 2,3-BD is easily dehydrated to methyl ethyl ketone (MEK), an excellent organic solvent for resins and lacquers, and to butadiene, for the production of polyesters and polyurethanes (Ji et al., 2011); it can also be easily dehydrogenated into acetoin and diacetyl, which are flavouring agents used in the food (dairy and margarine) and cosmetics industries; and it has potential applications in the production of inks, perfumes, softening and moisturising agents, explosives and plasticisers (Zeng and Sabra, 2011).

The main limitation of these bioprocesses is the high cost of the final product conditioned by the prices of the raw materials, which can amount between $30-50 \%$ of the production cost (Burk and Van Dien, 2016). Obtaining these bioproducts constitutes an advantage with respect to their equivalents of non-renewable origin and using renewable raw materials improves their competitiveness. In addition, biotransformation occurs under mild conditions, which is advantageous in comparison with any chemical transformation process. Therefore, this thesis aims to contribute in the development of value chains with bioproducts for new markets, i.e., chemicals and biopolymers will be obtained from low cost and renewable sources including: agricultural waste or surplus (Camelina sativa non-food crop), industrial residues (glycerol from biodiesel industry and orange peel waste from food processing industry) and the organic waste from earlier stage through composting process of municipal solid waste. 


\section{References}

Aguilar, A., Twardowski, T., Wohlgemuth, R. (2019) Bioeconomy for sustainable development. Biotechnol J 14(8):1800638.

Ahmann, D., and Dorgan, J. R. (2007). Bioengineering for pollution prevention through development of biobased energy and materials state of the science report. Indu Biotechnol 3(3), 218-259.

Alcalde, M., Ferrer, M., Plou, F.J., Ballesteros, A. (2006) Environmental biocatalysis: from remediation with enzymes to novel green processes. Trends Biotechnol 24(6), 281-287.

Ali, M.F., Ali, B.M., Speight, J.G. (2005). Handbook of industrial chemistry: organic chemicals. McGrawHill Education.

Amoah, J., Kahar, P., Ogino, C., Kondo, A. (2019) Bioenergy and biorefinery: feedstock, biotechnological conversion, and products. Biotechnol J 14(6):1800494.

Anastas, P. T. (2018) Origins and Early History of Green Chemistry, Series on Chemistry, Energy and the Environment, Advanced Green Chemistry, Part 1: Greener Organic Reactions and Processes, Horvath, I. T.; Malacria, M. (Eds.) World Scientific: Singapore.

Anastas, P.T. and Kirchhoff, M.M. (2002) Origin, Current Status, and Challenges of Green Chemistry. Acc Chem Res 35, 686-694.

Anastas, P. T. and Warner, J. C. (1998) Green Chemistry: Theory and Practice; Oxford University Press: Oxford.

Bardhan, S.K., Gupta, S., Gorman, M.E., Haider, M.A. (2015). Biorenewable chemicals: Feedstocks, technologies and the conflict with food production. Renew Sustain Energy Rev 51, 506-520.

Bastidas-Oyanedel, J.R. and Schmidt, J.E. (Eds.) (2019) Biorefinery: Integrated Sustainable Processes for Biomass Conversion to Biomaterials, Biofuels, and Fertilizers. Springer, Cham, Switzerland.

Berlin, A., Gilkes, N., Kilburn, D., Maximenko, V., Bura, R., Markov, A., Solovieva, I. Skomarovsky, A., Gusakov, A., Sinitsyn, A., Okuney, O., Soloviera, I., Saddler, J.N. (2006) Evaluation of cellulase preparations for hydrolysis of hardwood substrates. In Twenty-Seventh Symposium on Biotechnology for Fuels and Chemicals (pp. 528-545). Humana Press.

Bharathiraja, S., Suriya, J., Krishnan, M., Manivasagan, P., Kim, S. K. (2017) Production of enzymes from agricultural wastes and their potential industrial applications. In Advances in food and nutrition research (Vol. 80, pp. 125-148). Academic Press. 
Böhringer, C. and Jochem, P. (2007) Measuring the immeasurable - A survey of sustainability indices Ecol Econom 63,1- 8 Doi: 10.1016/j.ecolecon.2007.03.008.

Bozell, J.J. and Petersen, G.R. (2010) Technology development for the production of biobased products from biorefinery carbohydrates - the US Department of Energy's “Top 10" revisited. Green Chem 12(4): 539-554.

Brown, T. L. (2009). Chemistry: the central science. Pearson Education.

Budarin, V.L., Shuttleworth, P.S., Dodson, J.R., Hunt, A.J., Lanigan, B., Marriott, R., Milkowski, K.J., Wilson, A.J., Breeden, S.W., Fan, J., Sin, E.H.K., Clark, J.H. (2011) Use of green chemical technologies in an integrated biorefinery. Energy Environ Sci 4(2):471-479.

Burk, M. and Van Dien, S. (2016) Biotechnology for Chemical Production: Challenges and Opportunities. Trends Biotechnol 34: 187-190.

Buschke, N., Schäfer, R., Becker, J., Wittmann, C. (2013) Metabolic engineering of industrial platform microorganisms for biorefinery applications-optimization of substrate spectrum and process robustness by rational and evolutive strategies. Bioresour Technol 135, 544-554.

Caldeira, C., Vlysidis, A., Fiore, G., De Laurentiis, V., Vignali, G., Sala, S. (2020) Sustainability of food waste biorefinery: A review on valorisation pathways, techno-economic constraints, and environmental assessment. Bioresour Technol 312, 123575.

Carmona-Cabello, M., Garcia, I.L., Leiva-Candia, D., Dorado, M.P. (2018) Valorization of food waste based on its composition through the concept of biorefinery. Curr Opin Green Sust Chem 14, 67-79. Doi:10.1016/j.cogsc.2018.06.011.

Carus, M., Dammer, L. (2018) The "circular bioeconomy" - concepts, opportunities and limitations. Ind Biotech 14(2), 83-91.

Castilla-Archilla, J., O’Flaherty, V., Lens, P. N. (2019) Biorefineries: Industrial Innovation and Tendencies. In Biorefinery Springer, Cham 3-35.

Clark, J. and Deswarte, F. (2014) The Biorefinery Concept: An Integrated Approach. In Introduction to Chemicals from Biomass, 1, 1-20.

Clark, J.H. (2017) From waste to wealth using green chemistry: The way to long term stability. Curr Opin Green Sust Chem 8, 10-13. Doi:10.1016/j.cogsc.2017.07.008.

Clark, J.H. (2019). Green biorefinery technologies based on waste biomass. Green Chem 21(6), 11681170. 
Chang, C.-F., Weng, J.-H., Lin, K.-Y., Liu, L.-Y., Yang, S.-S. (2014) Phorbol esters degradation and enzyme production by Bacillus using Jatropha seed cake as substrate. Int J Environ Pollut Remediat 2:30-6.

Cherubini, F., Jungmeier, G., Wellisch, M., Willke, T., Skiadas, I., Van Ree, R., de Jong, E. (2009) Toward a common classification approach for biorefinery systems. Biofuel Bioprod Bioref 3(5), 534-546.

Cheburini, F., (2010) The biorefinery concept: Using biomass instead of oil for producing energy and chemicals. Energ Conv Manag 51: 1412-1421.

Corma, A., Iborra, S., Velty, A. (2007) Chemical routes for the transformation of biomass into chemicals. Chem Rev 107(6):2411-2502.

Cséfalvay, E., Akien, G. R., Qi, L., Horváth, I. T. (2015) Definition and application of ethanol equivalent: sustainability performance metrics for biomass conversion to carbon-based fuels and chemicals. Catal Today 239,50- 55 Doi: 10.1016/j.cattod.2014.02.006.

Dahiya, S., Kumar, A.N., Sravan, J.S., Chatterjee, S., Sarkar, O., Mohan, S.V. (2018) Food waste biorefinery: Sustainable strategy for circular bioeconomy. Bioresour Technol 248, 2-12.

de Gonzalo, G., and de María, P.D. (Eds.). (2017). Biocatalysis: an industrial perspective (Vol. 29). Royal Society of Chemistry.

de Jong, E., \& Jungmeier, G. (2015). Biorefinery concepts in comparison to petrochemical refineries. In Industrial biorefineries \& white biotechnology (3-33) Elsevier.

Diep, N.Q., Sakanishi, K., Nakagoshi, N., Fujimoto, S., Minowa, T., Tran, X.D. (2012) Biorefinery: concepts, current status, and development trends. Int J Biomass Renew 2(1):1-8.

Erickson, B., and Winters, P. (2012) Perspective on opportunities in industrial biotechnology in renewable chemicals. Biotechnol J 7(2), 176-185.

Fayyaz, M., Chew, K.W., Show, P.L., Ling, T.C., Ng, I.S., Chang, J.S. (2020) Genetic engineering of microalgae for enhanced biorefinery capabilities. Biotechnol adv 43, 107554.

Fernando, S., Adhikari, S., Chandrapal, C., Murali, N. (2006) Biorefineries: current status, challenges, and future direction. Energy Fuels 20(4), 1727-1737.

Ferreira, A.F. (2017). Biorefinery concept. In Biorefineries Springer Cham 1, 1-20.

Fiorentino, G., Ripa, M., Ulgiati, S. (2017) Chemicals from biomass: technological versus environmental feasibility. A review. Biofuels Bioprod Biorefin 11(1):195-214.

Gao, X., Chen, J.C., Wu, Q. Chen, G.Q. (2011) Polyhydroxyalkanoates as a source of chemicals, polymers, and biofuels. Curr Opin Biotechnol 22: 1-7. 
Gao, D., Uppugundla, N., Chundawat, S. P., Yu, X., Hermanson, S., Gowda, K., Brumm, P., Mead, D., Balan, V., Dale, B. E. (2011) Hemicellulases and auxiliary enzymes for improved conversion of lignocellulosic biomass to monosaccharides. Biotechnol Biofuel 4(1), 5.

Gullon, B., Yanez, B., Alonso, J.L., Parajo, J.C. (2008) L-Lactic acid production from apple pomace by sequential hydrolysis and fermentation. Bioresource Technol 99, 308-319.

Guo, H., Chang, Y., Lee, D.J. (2018) Enzymatic saccharification of lignocellulosic biorefinery: research focuses. Bioresour Technol 252, 198-215.

Gustavsson, M. and Lee, S.Y. (2016) Prospects of microbial cell factories developed through systems metabolic engineering. Microbial Biotechnol 9(5), 610-617.

Haddadi, M.H., Aiyelabegan, H.T., Negahdari, B. (2018) Advanced biotechnology in biorefinery: a new insight into municipal waste management to the production of high-value products. Int J Environ Sci Technol 15(3), 675-686.

Hay, L., Duffy, A., Whitfield, R. I. (2014) The Sustainability Cycle and Loop: Models for a more unified understanding of sustainability. J Environ Manage 133,232-257.

Heimann, T. (2019) Bioeconomy and SDGs: does the bioeconomy support the achievement of the SDGs? Earth's Future 7, 43-57.

Hellsmark, H. and Söderholm, P. (2017) Innovation policies for advanced biorefinery development: Key considerations and lessons from Sweden. Biofuel Bioprod Bioref 11(1), 28-40.

Heux, S., Meynial-Salles, I., O'Donohue, M. J., \& Dumon, C. (2015) White biotechnology: state of the art strategies for the development of biocatalysts for biorefining. Biotechnol adv 33(8), 1653-1670.

Horváth, I.T., Cséfalvay E., Mika, L.T., Debreczeni, M. (2017) Sustainability metrics for biomass based carbon chemicals. ACS Sustain Chem Eng 5,2734-2740. Doi:10.1021/acssuschemeng. 6 b03074.

Hossain, G.S., Liu, L., Du, G.C. (2017) Industrial bioprocesses and the biorefinery concept. In Current Developments in Biotechnology and Bioengineering Elsevier 3-27.

Huber, G. W., Iborra, S., Corma, A. (2006) Synthesis of transportation fuels from biomass: chemistry, catalysts, and engineering. Chem Rev 106(9), 4044-4098.

Huesemann, M.H. (2004) "The failure of eco-efficiency to guarantee sustainability: Future challenges for industrial ecology" Environ Prog 23(4), 264-270. 
Ioannidou, S.M., Pateraki, C., Ladakis, D., Papapostolou, H., Tsakona, M., Vlysidis, A., Kookosb, I.K., Koutinas, A. (2020) Sustainable production of bio-based chemicals and polymers via integrated biomass refining and bioprocessing in a circular bioeconomy context. Bioresour Technol 307, 123093.

Jiang, L.L., Zhou, J.J., Quan, C.S., Xiu, Z.L. (2017) Advances in industrial microbiome based on microbial consortium for biorefinery. Bioresour Bioproces 4(1), 1-10.

Ji, X.J., Huang, H., Ouyang, P.K. (2011) Microbial 2, 3-butanediol production: a state-of-the-art review. Biotechnol adv 29(3), 351-364.

Johansson, C., Bras, J., Mondragon, I., Nechita, P., Plackett, D., Simon, P., Svetec, D.G., Virtanen, S., Baschetti, M.G., Breen, C., Aucejo, S. (2012) Renewable fibers and bio-based materials for packaging applications-a review of recent developments. BioResources, 7(2), 2506-2552.

John, R.P., Nampoothiri, M., Pandey, A. (2007) Fermentative production of lactic acid from biomass:an overview on process developments and future perspectives. Appl Microbiol Biotechnol 74: 524-534.

Jovanovic, G.N. (2006) Microscale Reactors for Biodiesel Manufacture. Ind Bioprocces, 28(4): 6.

Jullesson, D., David, F., Pfleger, B., Nielsen, J. (2015) Impact of synthetic biology and metabolic engineering on industrial production of fine chemicals. Biotechnol adv 33(7), 1395-1402.

Kalmykova, Y., Sadagopan, M., Rosado, L. (2018) Circular economy-from review of theories and practices to development of implementation tools. Resour Conserv Recy 135, 190-201.

Kamm, B., and Kamm, M.J.A.M. (2004) Principles of biorefineries. Appl Microbiol Biotechnol 64(2)137145.

Kawaguchi, H., Ogino, C., Kondo, A. (2017) Microbial conversion of biomass into bio-based polymers. Bioresour Technol 245, 1664-1673.

Keasling, J.D. (2008). Synthetic Biology for Synthetic Chemistry. ACS Chem Biol 3(1): 64-76.

Kimura, Y. (2009) Molecular, structural, and material design of bio-based polymers. Polymer J, 41(10), 797-807.

Koutinas, A.A., Vlysidis, A., Pleissner, D., Kopsahelis, N., Lopez Garcia, I., Kookos, I.K., Papanikolaou, S., Kwan, T.H., Lin, C.S.K. (2014) Valorization of industrial waste and by-product streams via fermentation for the production of chemicals and biopolymers. Chem Soc Rev 43(8), 2587-2627.

Lackner, M. (2015) Bioplastics - Biobased plastics as renewable and/or biodegradable alternatives to petroplastics. In Kirk-Othmer encyclopedia of chemical technology, $6^{\text {th }}$ edition, Kirk-Othmer, Wiley 
Lappa, I.K., Papadaki, A., Kachrimanidou, V., Terpou, A., Koulougliotis, D., Eriotou, E., Kopsahelis, N. (2019) Cheese whey processing: integrated biorefinery concepts and emerging food applications. Foods 8(8), 347.

Larroche, C., Sanroman, M.A., Du, G., Pandey, A. (Eds.). (2017). Current developments in biotechnology and bioengineering: bioprocesses, bioreactors and controls. Elsevier.

Ligouri, R., Faraco, V. (2016) Biological processes for advancing lignocellulosic waste biorefinery by advocating circular economy. Bioresour Technol 215, 13-20. Doi:10.1016/j.biotech.2016.04.054.

Lin, W.R., Tan, S.I., Hsiang, C.C., Sung, P.K., Ng, I.S. (2019) Challenges and opportunity of recent genome editing and multi-omics in cyanobacteria and microalgae for biorefinery. Bioresour Techno/ 291, 121932.

Ma, J., Gu, Y., Marsafari, M., Xu, P. (2020) Synthetic biology, systems biology, and metabolic engineering of Yarrowia lipolytica toward a sustainable biorefinery platform. J Ind Microbiol Biotechnol 47(9-10), 845-862.

Masutani, K. and Kimura, Y. (2015).Biobased Polymers. Encyclopedia of Polymeric Nanomaterials. Berlin, Heidelberg: Springer Berlin Heidelberg.

McKendry, P., (2002) Energy production from biomass (part 1): overview of biomass. Bioresour Technol 83(1), 37-46.

Mohan, S.V., Dahiya, S., Amulya, K., Katakojwala, R., Vanitha, T.K. (2019) Can circular bioeconomy be fueled by waste biorefineries-A closer look. Bioresour Technol Rep 7,100277.

Mohan, S.R. (2016) Strategy and design of Innovation Policy Road Mapping for a waste biorefinery. Bioresour Technol 215, 76-83.

Morais, A. R., \& Bogel-Lukasik, R. (2013). Green chemistry and the biorefinery concept. Sustain Chem Process, 1(1), 1-3.

Moscoviz, R., Trably, E., Bernet, N., Carrère, H. (2018) The environmental biorefinery: state-of-the-art on the production of hydrogen and value-added biomolecules in mixed-culture fermentation. Green Chem 20(14), 3159-3179.

Muralidhararao, D., Hussain S.M.D.J., Rangadu, V.P., Krishna, G.S., Swamy, A.V.N. (2007) Fermentative production of itaconic acid by Aspergillus terreus using Jatropha seed cake. Afr J Biotechnol 6:2140-2.

Nizami, A. S., Rehan, M., Waqas, M., Naqvi, M., Ouda, O. K. M., Shahzad, K., Miandad, R., Khan, M.Z., Syamsiro, M., Ismail, I.M.I., Pant, D. (2017) Waste biorefineries: enabling circular economies in developing countries. Bioresour Technol 241, 1101-1117. 
Okano K., Tanaka T., Ogino C., Fukuda H., Kondo A. (2010) Biotechnological production of enantiomeric pure lactic acid from renewable resources : recent achievements, perspectives, and limits. App/ Microbiol Biotechnol 85: 413-423.

Patel, A.K., Singhania, R.R., Sim, S.J., Pandey, A. (2019) Thermostable cellulases: current status and perspectives. Bioresour Technol 279, 385-392.

Patermann, C. and Aguilar, A. (2018) The origins of the bioeconomy in the European Union. $N$ biotechnol 40, 20-24.

Patsalou, M., Menikea, K.K., Makri, E., Vasquez, M.I., Drouza, C., Koutinas, M. (2017) Development of a citrus peel-based biorefinery strategy for the production of succinic acid. J Clean Prod 166, 706-716.

Pfaltzgraff, L.A., de Bruyn, M., Cooper, E.C., Budarin, V., Clark, J.H. (2013) Food waste biomass: a resource for high-value chemicals. Green Chem 15, 307-314. Doi:10.1039/ C2GC36978h.

Pérez, A.T.E., Camargo, M., Rincón, P.C. N., Marchant, M.A. (2017) Key challenges and requirements for sustainable and industrialized biorefinery supply chain design and management: a bibliographic analysis. Renew Sustain Energy Rev 69, 350-359.

Peck, P., Bennett, S. J., Bissett-Amess, R., Lenhart, J., Mozaffarian, H. (2009) Examining understanding, acceptance, and support for the biorefinery concept among EU policy-makers. Biofuel Bioprod Bioref 3(3), 361-383.

Petre, M. (Ed.). (2013) Environmental Biotechnology: New Approaches and Prospective Applications. BoD-Books on Demand.

Philp, J., Winickoff, D., (2018) Realising the Circular Bioeconomy, OECD Science, Technology and Industry Policy Papers, No. 60. OECD Publishing, Paris.

Posada, J. A., Rincón, L. E., Cardona, C. A. (2012) Design and analysis of biorefineries based on raw glycerol: addressing the glycerol problem. Bioresour Technol 111, 282-293.

Prasad, S., and Roy, I. (2018) Converting enzymes into tools of industrial importance. Recent Pat Biotechnol 12(1), 33-56.

Quispe, C.A.G., Coronado, C.J.R., Carvalho, J.A. (2013) Glycerol: Production, consumption, prices, characterization and new trends in combustion. Renew Sustain Energy Rev 27, 475-493.

Raghavendra, M.P., Nayaka, S.C., Gupta, V.K. (2016) Microbial enzymes for conversion of biomass to bioenergy. In Microbial Enzymes in Bioconversions of Biomass (pp. 1-26). Springer, Cham. 
Ravindran, R. and Jaiswal, A.K. (2016) A comprehensive review on the pre-treatment strategy for lignocellylosic food industry waste: challenges and opportunities. Bioresour Technol 199: 92-102.

Robèrt, K.-H., Daly, H., Hawken, P., Holmberg, J. (1997) A compass for sustainable development. Int J Sustain Dev World Ecol 4, 79-92 Doi: 10.1080/13504509709469945.

Rudnitskaya, A., and Legin, A. (2008) Sensor systems, electronic tongues and electronic noses, for the monitoring of biotechnological processes. J Ind Microbiol Biotechnol 35(5), 443-451.

Sainger, M., Jaiwal, A., Sainger, P. A., Chaudhary, D., Jaiwal, R., \& Jaiwal, P. K. (2017) Advances in genetic improvement of Camelina sativa for biofuel and industrial bio-products. Renew Sustain Energy Rev 68, 623-637.

Saini, J.K., Saini, R., Tewari, L. (2015) Lignocellulosic agriculture wastes as biomass feedstocks for secondgeneration bioethanol production: concepts and recent developments. 3 Biotech 5, 337-353. Doi:10.1007/s13205-014-0246-5.

Sánchez, A.S., Silva, Y.L., Kalid, R.A., Cohim, E., Torres, E.A. (2017) Waste bio-refineries for the cassava starch industry: New trends and review of alternatives. Renew Sustain Energy Rev 73, 1265-1275.

Sharma, A., Sharma, A., Singh, S., Kuhad, R.C., Nain, L. (2019) Thermophilic Fungi and Their Enzymes for Biorefineries. In Fungi in Extreme Environments: Ecological Role and Biotechnological Significance (pp. 479-502). Springer, Cham.

Sheldon, R.A. (2018a) Chemicals from renewable biomass: a renaissance in carbohydrate chemistry. Curr Opin Green Sustain Chem 14, 89-95.

Sheldon, R.A. (2018b) The road to biorenewables: carbohydrates to commodity chemicals. ACS Sustain Chem Eng 6, 4464-4480. Doi:10.1021/acssuschemeng.8b00376.

Sheldon, R.A. (2020) Biocatalysis and biomass conversion: enabling a circular economy. Philos Trans Royal Soc A 378(2176), 20190274.

Singh, A., Jasso, R.M.R., Gonzalez-Gloria, K.D., Rosales, M., Cerda, R.B., Aguilar, C. N., Singhania, R.R., Ruiz, H.A. (2019). The enzyme biorefinery platform for advanced biofuels production. Bioresour Technol Rep 7, 100257.

Stephanopoulos, G. (2007) Challenges in engineering microbes for biofuels production. Science, 315(5813), 801-804

Stegmann, P., Londo, M., and Junginger, M. (2020). The circular bioeconomy: Its elements and role in European bioeconomy clusters. Resour Conserv Recy X, 6, 100029. 
Strazzera, G., Battista, F., Garcia, N.H., Frison, N., Bolzonella, D. (2018) Volatile fatty acids production from food wastes for biorefinery platforms: A review. J Environ Manag 226, 278-288.

Solaiman, D.K.Y., Ashby, R.D., Foglia, T.A., Marmer, W.N. (2006) Conversion of agricultural feedstock and coproducts into poly(hydroxyalkanoates). Appl Microbiol Biotechnol 71: 783-789.

Taherzadeh M.J. and Karimi, K. (2008) Pretreatment of lignocellulosic wastes to improve ethanol and biogas production: a review. Int J Mol Sci 9: 1621-1651.

Tuck, C.O., Perez, E., Horvath, I.T., Sheldon, R.A., Poliakoff, M. (2012) Valorization of biomass: deriving more value from waste. Science 337, 695-699. doi:10.1126/science.1218930.

Tursi, A. (2019) A review on biomass: importance, chemistry, classification, and conversion. Biofuel Res J 6(2), 962.

Velasco, D., Senit, J.J., de la Torre, I., Santos, T.M., Yustos, P., Santos, V.E., Ladero, M. (2017) Optimization of the enzymatic saccharification process of milled orange wastes. Fermentation, 3(3), 37.

Vertès, A.A., Inui, M., Yukawa, H. (2007) Alternative technologies for biotechnological fuel ethanol manufacturing. J Chem Technol Biotechnol 82(8), 693-697.

Wenda, S., Illner, S., Mell, A., Kragl, U. (2011) Industrial biotechnology-the future of green chemistry? Green Chem 13(11), 3007-3047.

Zeng, A.-P. and Sabra, W. (2011) Microbial production of diols as platform chemicals: recent progresses. Curr Op Biotechnol 22: 749-757. 


\section{JUSTIFICATION, OBJECTIVES AND SCOPE}


World population growth - expected to increase by more than $30 \%$ over the next 40 years rapid depletion of many resources, external energy dependence coupled with price instability, increased pressure on the environment and climate change are factors that require Europe to radically change the way it produces, consumes, transforms, stores, recycles and disposes of biological resources. These resources are increasingly relevant for meeting both the demand for healthy and safe food and for obtaining chemicals, energy and other materials.

Nowadays, petroleum is the main raw material for the production of chemicals and plastics. The annual capacity of petroleum-derived plastics produced worldwide is currently disposed mainly in landfills, it is incinerated or it is disposed to the sea. Biomass and biomass-related wastes are positioned as renewable sources of energy, but also of carbon, capable of acting as a precursor to numerous and diverse products, both energy and non-energy. All of these actions fall within the framework of bioeconomics. The chemical industry is no stranger to this whole process, in fact, has been involved in the bioeconomy for many years as evidenced by the placing on the market of various conventional products for other sustainable products. These products have very diverse applications among which are the textile industry, cosmetics, pharmaceutical or automotive, among others. The production of sustainable chemicals and biodegradable plastics is the only solution to the replacement of petroleum-derived products.

The study and development of new sustainable processes and technologies on the use of renewable raw materials for the production of environmentally friendly polymers and biological chemicals is highly needed. Industrial biotechnology within the concept of biorefinery offers a promising way to develop sustainable processes and obtain valuable products through the use of biomass and biowaste. The use of biocatalysts, such as microorganisms, opens up a wide range of possibilities, as they are capable of transforming a great variety of substrates into sustainable, high-value products that in turn can compete with products obtained through conventional chemical processes. Therefore, the search for robust strains capable of transforming complex substrates is needed to promote the industrial upscaling of the bioprocesses in which they are involved.

In this context, the general aim of this thesis is the study and development of biotechnological processes for the production of bio-based chemicals and polymers in a sustainable manner. This work focuses in the utilization of low cost and renewable sources including agricultural waste or surplus, industrial residues and municipal solid waste for the production of polyhydroxyalkanoates, 2,3-butanediol and D-lactic acid. Obtaining these bioproducts constitutes an advantage with respect to their equivalents of non-renewable origin since (i) in 
the case of D-lactic acid, the chemical process of obtaining, in addition to being energy and catalyst intensive, generates the racemic mixture, (ii) in the case of 2.3-butanediol, the chemical route requires expensive catalysts and (iii) in the case of PHA, the polyolefins are not biodegradable. The use of renewable bio-resources as feedstock improves their competitiveness, since the greatest limitation to their implementation is the high contribution to the cost of the process by the raw materials used in fermentation. In addition, microbial transformations occur under mild pressure and temperature conditions, which is advantageous in comparison with any chemical transformation process.

For polyhydroxyalkanoates production, whey and camelina oil have been selected as substrates with special attention to the search for microorganisms capable of consuming the corresponding lactose and lipids without any pretreatment stage. In the other hand, glycerol and municipal organic residues (organic waste from earlier stage through composting process) have been selected for the production of 2,3-butanediol, focusing on obtaining improved and robust microorganisms able to use these substrates efficiently. Finally, orange peel waste has been selected as feedstock for the screening of lactic bacteria strains producing D-lactic acid with high yield and optical purity. Thus, for the development of this work, specific objectives have been addressed as follows:

$>$ The first objective of this thesis has been the characterization of the selected feedstocks and the subsequent definition of the pre-treatment method for their use. Different analytical methods have been applied for this purpose depending on the nature of each substrate, i.e., chromatography, elemental analysis, colorimetric kits and NREL procedures for compositional characterization in the case of complex substrates. For the latter, such as organic residues and orange peel waste, enzymatic hydrolysis procedures have been established to release the sugars for the fermentation stage.

> In turn, the bacterial strains selected for this work have been identified using microorganism databases and specialized literature. Subsequently, these strains have been acquired from type culture collections and subjected to screening and tolerance assays to the corresponding feedstock. Thus, the second objective of this thesis has been the identification and selection of microorganisms, or biocatalysts, with potential use in obtaining the bioproducts of interest. In addition, random mutagenesis techniques have been implemented to obtain improved strains.

D With regard industrial applications, the third objective in this thesis has been the development and validation of the bioprocesses at lab scale and a prelimary upscaling 
analysis. First, a review of the background and methodologies for each bioprocess under study has been carried out. Then, fermentation trials have been planned and performed from the proof of concept, optimization at flask scale and validation in bioreactor, in batch and fed-batch afterwards. The results obtained have been discussed within the framework of sustainability and considering the feasibility of upscaling of the bioprocesses under study.

The present work was carried out at the biotechnological company ADM-Biopolis (http://biopolis.es/), focused in finding and developing microorganisms for industrial and health-related purposes. For this reason, the underlying objective of this thesis is to contribute to the validation of industrial biocatalysts using renewable resources for the development of safer and sustainable industrial bioprocesses. 


\section{EXPERIMENTAL WORK AND RESULTS}


The publications derived from the research work performed were adapted for this dissertation, and therefore, the present section has been structured in five chapters as follows:

Chapter I reveals the species Caulobacter segnis as a polyhydroxyalkanoates producer from whey without any pretreatment and experimentally validates the in silico bioprospecting strategy for selecting microorganism for waste re-valosation.

$>$ In Chapter II, Camelina oil was shown to be a suitable substrate for production of mediumchain-length polyhydroxyalkanoates with a strain of Pseudomonas sp. without any pretreatment.

$>$ In Chapter III, the strain Raoultella planticola was subjected to random mutagenesis techniques and two mutant strains were found to produce at least $30 \%$ more 2,3-butanediol from glycerol than the wild type strain.

$>$ Chapter IV refers to a procedure for obtaining 2,3-butanediol from organic waste hydrolysates using microorganisms, particularly by using Raoultella planticolla strains.

Finally, several strains of the species Lactobacillus delbrueckii ssp. bulgaricus have been evaluated in Chapter V for the production of D-lactic acid from orange peel waste hydrolysates with high enantiomeric excess.

\section{LIST OF PUBLICATIONS}

I. Bustamante, D., Segarra, S., Tortajada, M., Ramón, D., Del Cerro, C., Prieto, M.A., Iglesias, J.R., Rojas, A. (2019) In silico prospection of microorganisms to produce polyhydroxyalkanoate from whey: Caulobacter segnis DSM 29236 as a suitable industrial strain. Microbial biotechnology, 12(3), 487-501.

II. Bustamante, D., Tortajada, M., Ramon, D., Rojas, A. (2019). Camelina oil as a promising substrate for mcl-PHA production in Pseudomonas sp. cultures. Applied Food Biotechnology, 6(1), 61-70.

III. Bustamante, D., Segarra, S., Montesinos, A., Tortajada, M., Ramón, D., Rojas, A. (2019) Improved Raoultella planticola strains for the production of 2,3-butanediol from glycerol. Fermentation, 5(1), 11.

IV. Bustamante, D., Sanchis-Amat, M., Rojas A., Tortajada M., Ramón, D., Ferrer L., Sala F., Pascó, J.I. (2019) Procedure for obtaining 2,3-butanediol by fermentation of hydrolyzed substrates of organic waste (ow) with microorganisms. Patent WO2019180220A1: Spain.

V. Bustamante, D., Tortajada, M., Ramón, D., Rojas, A. (2020). Production of D-lactic acid by the fermentation of orange peel waste hydrolysate by lactic acid bacteria. Fermentation, 6(1), 1. 


\section{CHAPTER I}

In silico prospection of microorganisms to produce polyhydroxyalkanoate from whey: Caulobacter segnis DSM 29236 as a suitable industrial strain 


\subsection{Background and aim}

The use of industrial secondary manufacturing streams as feed-stocks is one of the main objectives of the bioeconomy. Therefore, processing methods are used in bio-refineries to develop more sustainable and environmentally friendly technologies. Industrial biotechnology and the development of specialized microbial factories, including genetically modified organisms (GMOs) may offer alternative paths to conventional processes and, consequently, proof of concept has been shown that many products traditionally produced from petroleum like plastic materials, can now be synthesized using renewable resources. Alternative biobased plastics offering the same functionalities of traditional plastics with potentially lower environmental impacts, are being developed, but at the moment represent a very small share of the market (Prieto, 2016). Increasing the uptake of alternatives that according to solid evidence are more sustainable can also help decrease our dependency on fossil fuels (http://ec.europa.eu/environment/circular-economy/pdf/plastics-strategy-annex.pdf). In this scenario, the current socioeconomic trend towards sustainable development models has promoted research into the generation of bioplastics such as polyhydroxyalkanoates (Braunegg et al., 2004; Koller et al., 2017; Dietrich et al, 2017).

Polyhydroxyalkanoates have a renewable origin, with similar properties to polyolefins. They are biodegradable and biocompatible. Moreover their water and oxygen permeability is low, and therefore they can be used in packaging (Verlinden et al., 2007; Koller, 2014). Their hydrolysis products (3-R-hydroxyalkanoic acids) are optically active molecules of high pharmaceutical interest (Chen and $\mathrm{Wu}, 2005$ ). The properties of PHA depend on the length of the lateral chain: short-chain-length PHAs, like poly(3-hydroxybutyrate) (PHB), have higher crystallinity, are thermoplastic and behave as polypropylene, whereas medium-chain-length PHAs behave like elastomers. They have a wide range of applications in medicine, pharmacy, veterinary and food packaging (Chen, 2009; Brigham and Sinskey, 2012; Dinjaski and Prieto, 2015; Raza et al., 2018). The challenge facing this clean production technology lies in the ability to obtain bioplastics at a similar or lower cost than those from petrochemical origin. Some small and middle-sized companies produce PHA at small scale. For example, P\&G (USA), Biomer Inc. (Germany), Tianan Biologic (China) and PHB Industrial (Brazil) (Jiang et al., 2016).

The price of these products is still higher than their conventional counterparts, although in recent years some companies report values as low as $\$ 1.50 \mathrm{~kg}^{-1}$ (Chanprateep, 2010). Lately, efforts have been made to improve the fermentation and extraction process required to 
produce them, as well as to isolate and develop more productive microbial strains that can use low-cost substrates (Khanna and Srivastava, 2005; Mozejko-Ciesielska and Kiewisz, 2016). In fact, raw material accounts for $30-40 \%$ of the total cost of PHB; therefore, using renewable raw materials is fundamental to obtain profitable and environmentally friendly processes. Raw materials may include waste material from other industrial processes (Castilho et al., 2009, Sathya et al., 2018), such as whey.

Whey is generated in cheese factories on separating the milk curd, and is one of the most polluting materials generated by the food industry due to its high organic and mineral content. It is a product rich in protein, fat and lactose (Spalatelu, 2012; Fernandez-Gutierrez, 2017). Studies have assessed the recovery of whey as a source of lactic acid, xanthan gum, lactitol and lactulose. In this respect, it is interesting to consider the production of bioplastics and derivatives thereof from whey (Mollea et al., 2013, Pescuma et al., 2015). Global production of whey is estimated at around $90 \times 10^{6}$ ton per year and growing. With milk and cheese production rising globally each year by $2 \%$ and $3 \%$, respectively, evidence suggests that the volume of whey produced will continue to increase in the coming years (Ryan and Walsh, 2016). Thus advances in the field of biotechnology to develop sustainable methods of dealing with whey are necessary. In the same vein, the optimization of PHA production processes is an interesting approach for exploiting the potential of whey.

PHAs are produced as carbon and energy reserves or reducing power storage materials in the presence of excess carbon, especially with limitation of other essential nutrients such as oxygen, nitrogen or phosphorus (Koller et al., 2008; Anjum et al., 2016). Some bacteria are able to use the lactose in whey to synthesize PHA. The prior art reports different types of PHA produced from whey or lactose by Gram-negative bacteria (Methylobacterium sp., Pseudomonas sp. or Thermus thermophilus) and Gram-positive bacteria, some lactic acid bacteria (genera Lactobacillus and Lactococcus) and Bacillus megaterium (Koller et al., 2012; Pais et al., 2014; Pais et al., 2016). Within the Caulobacter genus, the species C. crescentum has been described as producing PHA from glucose as carbon source (Qi and Rehm, 2001).

The development of genetic engineering techniques and intensive studying of metabolic potential of microorganisms has allowed designing genetically modified microorganisms (GMOs). They are applied in a variety of fields such as human health, agriculture, bioremediation and different types of industry (Cases and de Lorenzo, 2005; Jones et al., 2015). However, there is a strong social debate, mainly in the European Union, about the use of GMOs (Sankar and Cho, 2015). To select wild-type microorganisms that transform residual 
streams, such as whey, into a product of interest in an efficient way is a challenging issue. The strategies can be i) culture-based approaches consisting in the isolation of microorganisms from residual sources, and ii) in silico prospection of wild type microorganisms that takes advantages of the large amount of data generated by genome and metagenome sequencing projects (Walsh et al., 2015; Zarins-Tutt et al., 2016).

Since PHA production is a step forward in the processing of whey and has the potential to ecologically overcome fossil polymers as shown in lifecycle studies (Koller et al., 2013; Narodoslawsky et al., 2015), the aim of this work is to find new bacterial species capable of producing PHA from whey with high yield, through an in silico prospection and subsequent experimental validation.

\subsection{Materials and methods}

\subsubsection{Bacterial strains, media and growth conditions}

The bacterial strains employed in this study are listed in Table 2. The selected strains were purchased from the Spanish (CECT), German (DSMZ) and British (NCIMB) Type Culture Collections (Table 2). After receiving the strains, they were recovered in the media recommended by the supplier and stored in $20 \%$ glycerol for long-term preservation.

Cells were initially cultured in an undefined rich medium (Luria-Bertani, LB). The strains were

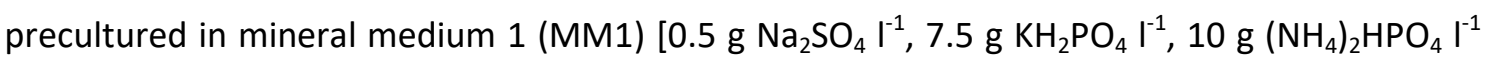
and $25 \mathrm{ml}$ per liter of trace elements solution: $0.5 \mathrm{~g} \mathrm{MgSO}_{4} \cdot 7 \mathrm{H}_{2} \mathrm{Ol}^{-1}, 2 \mathrm{mg} \mathrm{H}_{3} \mathrm{BO}_{3} \mathrm{I}^{-1}, 1$ $\mathrm{CuSO}_{4} \cdot 5 \mathrm{H}_{2} \mathrm{O} \mathrm{mg} \mathrm{l} l^{-1}, 1.3 \mathrm{mg} \mathrm{Na}_{2} \mathrm{MoO}_{4} \cdot 2 \mathrm{H}_{2} \mathrm{Ol}^{-1}, \mathrm{mg} \mathrm{ZnSO} \cdot \cdot 7 \mathrm{H}_{2} \mathrm{O} 11 \mathrm{I}^{-1}, 2 \mathrm{mg} \mathrm{CoCl} \cdot 6 \mathrm{H}_{2} \mathrm{O} \mathrm{I}{ }^{-1}, 7 \mathrm{mg}$ $\mathrm{MnSO}_{4} \cdot \mathrm{H}_{2} \mathrm{Ol}^{-1}, 35 \mathrm{mg} \mathrm{FeSO}{ }_{4} \cdot 7 \mathrm{H}_{2} \mathrm{Ol}^{-1}, 2.5 \mathrm{~g} \mathrm{KH}_{2} \mathrm{PO}_{4} \mathrm{I}^{-1}, 50 \mathrm{mg} \mathrm{CaCl} \cdot 2 \mathrm{H}_{2} \mathrm{Ol}^{-1}, 0.5 \mathrm{~g}$ citric acid l${ }^{-1}$, $\left.0.35 \mathrm{mg} \mathrm{KI} \mathrm{I}^{-1}, 0.5 \mathrm{~g} \mathrm{Al}_{2}\left(\mathrm{SO}_{4}\right)_{3} \mathrm{I}^{-1}\right]$, with lactose as sole carbon source in order to adapt them to the presence of sugar (Young et al., 1994). Solid media were prepared with 1.5\% (w/v) agar.

Different culture media, including diluted whey, were used to optimize PHA production with Caulobacter segnis DSM 29236: Mineral medium 2 (MM2) [1.2 $\mathrm{g} \mathrm{Na}_{2} \mathrm{HPO}_{4} \mathrm{I}^{-1}, 0.33 \mathrm{~g} \mathrm{KH}_{2} \mathrm{PO}_{4} \mathrm{I}^{-1}$, $0.11 \mathrm{~g} \mathrm{NH}_{4} \mathrm{Cl} \mathrm{I}^{-1}, 0.1 \mathrm{~g} \mathrm{MgSO}_{4} \cdot 7 \mathrm{H}_{2} \mathrm{Ol}^{-1}, 0.04 \mathrm{~g} \mathrm{CaCl}_{2} \mathrm{I}^{-1}$. Vitamins 1000x: $20 \mathrm{mg}$ biotin I${ }^{-1}, 20 \mathrm{mg}$ folic acid $\mathrm{I}^{-1}, 10 \mathrm{mg}$ pyridoxine $\cdot \mathrm{HCl}^{-1}, 50 \mathrm{mg}$ thiamine $\cdot \mathrm{HCl}^{-1} 2 \mathrm{H}_{2} \mathrm{Ol}^{-1}, 50 \mathrm{mg}$ riboflavin $\mathrm{I}^{-1}, 50 \mathrm{mg}$ niacin $\mathrm{I}^{-1}, 50 \mathrm{mg} \mathrm{D-pantothenate} \mathrm{calcium} \mathrm{I}^{-1}, 50 \mathrm{mg}$ vitamin B12 $\mathrm{I}^{-1}, 50 \mathrm{mg} \mathrm{p}$-aminobenzoic acid $\mathrm{I}^{-1}$. Trace elements 1000x: $1.5 \mathrm{~g}$ Nitrilotriacetic acid $\mathrm{I}^{-1}, 0.18 \mathrm{~g} \mathrm{ZnSO}_{4} \cdot 7 \mathrm{H}_{2} \mathrm{Ol}^{-1}, 3 \mathrm{~g} \mathrm{MgSO}_{4} \cdot 7 \mathrm{H}_{2} \mathrm{O} \mathrm{I}$ ${ }^{1}, 0.01 \mathrm{~g} \mathrm{CuSO}_{4} \cdot 5 \mathrm{H}_{2} \mathrm{O} \mathrm{I}^{-1}, 0.5 \mathrm{~g} \mathrm{MnCl}_{2} \cdot 4 \mathrm{H}_{2} \mathrm{O} \mathrm{I}{ }^{-1}, 0.02 \mathrm{~g} \mathrm{KAl}\left(\mathrm{SO}_{4}\right)_{3} \cdot 12 \mathrm{H}_{2} \mathrm{O} \mathrm{I}^{-1}, 1 \mathrm{~g} \mathrm{NaCl} \mathrm{I}^{-1}, 0.01 \mathrm{~g}$ 
$\mathrm{H}_{3} \mathrm{BO}_{3} \mathrm{I}^{-1}, 0.1 \mathrm{~g} \mathrm{FeSO}_{4} \cdot 7 \mathrm{H}_{2} \mathrm{O} \mathrm{I} I^{-1}, 0.01 \mathrm{~g} \mathrm{Na}_{2} \mathrm{MoO}_{4} \mathrm{I}^{-1}, 0.18 \mathrm{~g} \mathrm{CoSO}_{4} \cdot 7 \mathrm{H}_{2} \mathrm{Ol}^{-1}, 0.025 \mathrm{~g} \mathrm{NiCl}_{2} \cdot 6 \mathrm{H}_{2} \mathrm{O} \mathrm{I}^{-1}$, $0.3 \mathrm{~g} \mathrm{NaSeO}_{3} \cdot 5 \mathrm{H}_{2} \mathrm{O} \mathrm{I}^{-1}$ ] (Lopez Barragan et al., 2004), Mineral Medium 3 (MM3) [2.5 g Na $2 \mathrm{HPO}_{4}$ $\mathrm{I}^{-1}, 1.0 \mathrm{~g} \mathrm{KH}_{2} \mathrm{PO}_{4} \mathrm{I}^{-1}$. Trace elements $400 \times 5 \mathrm{M} \mathrm{HCl} 10 \mathrm{~g} \mathrm{FeSO}_{4} \cdot 7 \mathrm{H}_{2} \mathrm{O} \mathrm{I}^{-1}, 2 \mathrm{CaCl}_{2} \cdot 2 \mathrm{H}_{2} \mathrm{O} \mathrm{g} \mathrm{l}{ }^{-1}, 2.2 \mathrm{~g}$ $\mathrm{ZnSO}_{4} \cdot 7 \mathrm{H}_{2} \mathrm{Ol}^{-1}, 0.5 \mathrm{~g} \mathrm{MnSO}_{4} \cdot 4 \mathrm{H}_{2} \mathrm{Ol}^{-1}, 1 \mathrm{~g} \mathrm{CuSO}_{4} \cdot 5 \mathrm{H}_{2} \mathrm{Ol}^{-1}, 0.1 \mathrm{~g}\left(\mathrm{NH}_{4}\right)_{6} \mathrm{Mo}_{7} \mathrm{O}_{24} \cdot 4 \mathrm{H}_{2} \mathrm{O} \mathrm{I} \mathrm{I}^{-1}, 0.02 \mathrm{~g}$ $\mathrm{Na}_{2} \mathrm{~B}_{4} \mathrm{O}_{7} \cdot 10 \mathrm{H}_{2} \mathrm{Ol}^{-1}, 8 \mathrm{mg} \mathrm{NiCl} \cdot 6 \mathrm{H}_{2} \mathrm{Ol}^{-1}, 2.4 \mathrm{mg} \mathrm{CoCl} \cdot 6 \mathrm{H}_{2} \mathrm{O} \mathrm{I}^{-1}$ ] (Yellore and Desai, 1998), Mineral Medium 4 (MM4) [whey supplemented with $\mathrm{FeCl}_{3}$ and vitamins] (Povolo and Casella, 2003), Mineral Medium 5 (MM5) [0.5 $\mathrm{g} \mathrm{NHCO}_{3} \mathrm{I}^{-1}, 2.9 \mathrm{~g} \mathrm{Na}_{2} \mathrm{HPO}_{4} \mathrm{I}^{-1}, 2.3 \mathrm{~g} \mathrm{KH}_{2} \mathrm{PO}_{4} \mathrm{I}^{-1}, 0.5 \mathrm{~g}$ $\mathrm{MgSO}_{4} \cdot 7 \mathrm{H}_{2} \mathrm{O} \mathrm{I} \mathrm{I}^{-1}, 2 \mathrm{~g}\left(\mathrm{NH}_{4}\right)_{2} \mathrm{SO}_{4} \mathrm{I}^{-1}, 0.01 \mathrm{~g} \mathrm{CaCl}_{2} \cdot 2 \mathrm{H}_{2} \mathrm{O} \mathrm{I}{ }^{-1}, 0.05 \mathrm{~g} \mathrm{NH}_{4} \mathrm{Fe}(\mathrm{III})$ citrate $\mathrm{I}^{-1}$ and $5 \mathrm{~mL}$ per liter of SL6 solution: $100 \mathrm{mg} \mathrm{ZnSO} \cdot 7 \mathrm{H}_{2} \mathrm{Ol}^{-1}, 300 \mathrm{mg} \mathrm{H} \mathrm{BO}_{3} \mathrm{I}^{-1}, 200 \mathrm{mg} \mathrm{CoCl} \cdot 6 \mathrm{H}_{2} \mathrm{Ol}^{-1}, 6 \mathrm{mg}$ $\mathrm{CuSO}_{4} \mathrm{I}^{-1}, 20 \mathrm{mg} \mathrm{NiCl}_{2} \cdot 6 \mathrm{H}_{2} \mathrm{O} \mathrm{I}^{-1}, 30 \mathrm{mg} \mathrm{Na} \mathrm{MoO}_{4} \cdot 12 \mathrm{H}_{2} \mathrm{Ol}^{-1}, 25 \mathrm{mg} \mathrm{MnCl} \cdot 2 \mathrm{H}_{2} \mathrm{Ol}^{-1}$ ] (Koller et al.,

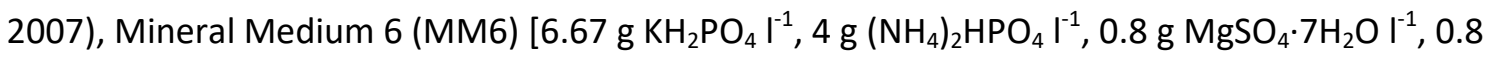
g citric acid $\mathrm{I}^{-1}$ and $5 \mathrm{~mL}$ per liter of solution trace elements $(5 \mathrm{M} \mathrm{HCl}): 10 \mathrm{~g} \mathrm{FeSO}_{4} \cdot 7 \mathrm{H}_{2} \mathrm{Ol}^{-1}, 2 \mathrm{~g}$ $\mathrm{CaCl}_{2} \cdot 2 \mathrm{H}_{2} \mathrm{O} \mathrm{I}^{-1}, 2.2 \mathrm{~g} \mathrm{ZnSO}_{4} \cdot 7 \mathrm{H}_{2} \mathrm{O} \mathrm{I}{ }^{-1}, 0.5 \mathrm{~g} \mathrm{MnSO}_{4} \cdot 4 \mathrm{H}_{2} \mathrm{O} \mathrm{I} \mathrm{I}^{-1}, 1 \mathrm{~g} \mathrm{CuSO} \cdot 5 \mathrm{H}_{2} \mathrm{O} \mathrm{I}^{-1}, 0.1 \mathrm{~g}$ $\left(\mathrm{NH}_{4}\right)_{6} \mathrm{Mo}_{7} \mathrm{O}_{24} \cdot 4 \mathrm{H}_{2} \mathrm{O} \mathrm{I}^{-1}, 0.02 \mathrm{~g} \mathrm{Na}_{2} \mathrm{~B}_{4} \mathrm{O}_{7} \cdot 10 \mathrm{H}_{2} \mathrm{O} \mathrm{I}^{-1}$ ] (Ahn et al., 2000) and Mineral Medium 7 (MM7) [5 g $\left(\mathrm{NH}_{4}\right)_{2} \mathrm{SO}_{4} \mathrm{I}^{-1}, 2.5 \mathrm{~g} \mathrm{Na}_{2} \mathrm{HPO}_{4} \mathrm{I}^{-1}, 2.5 \mathrm{~g} \mathrm{KH}_{2} \mathrm{PO}_{4} \mathrm{I}^{-1}, 0.2 \mathrm{~g} \mathrm{MgSO}_{4} \mathrm{I}^{-1}$, and $0.01 \mathrm{~g} \mathrm{MnSO}_{4} \mathrm{I}^{-}$ ${ }^{1}$ ] (Obruca et al., 2011). The $\mathrm{pH}$ value was set to 7 in all cases and then whey was added to achieve an initial lactose concentration of $12 \mathrm{~g} \mathrm{I}^{-1}$. Bacteria were incubated in flasks with stirring, at $30^{\circ} \mathrm{C}$ and $180 \mathrm{rpm}$. Growth was measured by absorbance at $600 \mathrm{~nm}$ in a spectrophotometer, or by cell dry weight (CDW) determination of freeze-dried samples. Optimization assays were carried out in the micro-reactor Applikon $\mu-24$, with $3 \mathrm{ml}$ of reaction volume, at $30^{\circ} \mathrm{C}$ and stirring at $500 \mathrm{rpm}$. pH was left to develop without restraint.

\subsubsection{Fed-batch cultures}

Seed cultures for the fed-batch cultures were prepared in flasks containing LB medium by incubating in a rotary shaker overnight at $30^{\circ} \mathrm{C}$ and $150 \mathrm{rpm}$. The experiments were performed in a 1.5-I Applikon ${ }^{\circledR}$ reactor with a working volume of 0.5 liter at $30^{\circ} \mathrm{C}$. $\mathrm{pH}$ was controlled at 7.0 by the addition of $25 \% \mathrm{v} / \mathrm{v}$ ammonia. The oxygen saturation was controlled at $30 \%$ by controlling the agitation speed and at $1 \mathrm{vvm}$ of air flow rate. Foaming was controlled by adding Antifoam 204 (Sigma-Aldrich) when necessary. Two sets of fermentations were carried out with Caulobacter segnis strain: (i) fermentation with MM3-modified medium supplemented with $0.5 \mathrm{~g} \mathrm{l}^{-1} \mathrm{MgSO}_{4}$ and $0.1 \mathrm{~g} \mathrm{l}^{-1}\left(\mathrm{NH}_{4}\right)_{2} \mathrm{SO}_{4}$ with subsequent feedings of whey, and (ii) fermentation with MR medium (Lee et al., 2000) with the initial $\mathrm{KH}_{2} \mathrm{PO}_{4}$ concentration set at 4 
$\mathrm{gl}^{-1}$ and continuous feeding of concentrated whey with around $200 \mathrm{gl}^{-1}$ of lactose by using dry whey diluted in water (x5). Detailed feeding strategies are described in the results section.

\subsubsection{Analytical methods}

The content of lactose, glucose and lactic acid was determined by HPLC liquid chromatography (Waters 2695 HPLC with a Refractive index detector 2414) using a Rezex ROA Organic Acid column, with $\mathrm{H}_{2} \mathrm{SO}_{4}$ at $2.5 \mathrm{mM}$ and $0.5 \mathrm{ml} \mathrm{min}^{-1}$ flow. Additional analysis of lactose was performed with the Colorimetric Kit Megazyme K-LACGAR Lactose and D-Galactose (Rapid). Protein was measured with a Thermo Fisher commercial Kit (Pierce BCA Protein Assay Kit) using the $B C A$ method. Fat was determined by Soxhlet extraction of dried whey with chloroform. The ash content was determined in a high temperature muffle furnace, Nabertherm GmbH. A CE Instruments CHN1100 elemental analyzer was used to perform an elemental analysis of whey by atomic spectrometry of $\mathrm{C}, \mathrm{N}, \mathrm{H}$ and $\mathrm{S}$. Oxygen content is estimated by difference. Data are shown in dry basis.

PHA was determined by methanolysis and gas chromatography of lyophilized culture samples. For this purpose, after 48 hours incubation, biomass was collected from $50 \mathrm{ml}$ cultures by centrifugation and lyophilized. Methanolysis reaction was performed weighing 5-7 mg of dry cells, using $\mathrm{H}_{2} \mathrm{SO}_{4}$ in $15 \%(\mathrm{v} / \mathrm{v})$ in methanol and chloroform, and incubating for 4 hours at $100^{\circ} \mathrm{C}$ to transform the PHA into hydroxy methyl esters. Methyl benzoate was used as an internal standard. The resulting methyl esters were collected in the chloroform phase and analyzed by gas chromatography (Lageveen et al, 1988). Different pure commercial PHA samples were used as bioplastic standard: PHB poly(3-hydroxybutyrate), PHBV poly(3-hydrobutyrate-co-3Hydroxyvalerate), and PHO poly(3-hydroxyhexanoate-co-3-hydrooctanoate). The equipment used was an Agilent 6890N gas chromatograph with flame ionization detector (FID) and HP5MS column.

PHA quantification for micro-reactor assays was performed with slight modifications (Cruz et al., 2016). Briefly, 2-3 mg of dry cells was obtained from $3 \mathrm{ml}$ of a culture of Caulobacter segnis with MM3 medium considering that a concentration of $0.7 \mathrm{gl}^{-1}$ of CDW was reached (Figure 2). Samples were weighed at an analytical balance with a precision of $0.1 \mathrm{mg}$, imposing an error of $4 \%$ of total biomass. Therefore, PHB percentages below $4 \%$ are rejected. This biomass amount corresponds to half of the sample used in the method described above, therefore in this case methanolysis reagents were used at half volume for 3.5 hours at $100^{\circ} \mathrm{C}$. 


\subsubsection{Whey preparation}

In order to use the whey as a basis for bacterial cultures it must first be sterilized. Two methods were followed: filtering or heating in an autoclave. In the former, the whey was passed through several filters $(25 \mu \mathrm{m}, 8 \mu \mathrm{m}, 1 \mu \mathrm{m}, 0.45 \mu \mathrm{m}$ and $0.22 \mu \mathrm{m})$ to remove suspended particles and microorganisms; in the latter, sterilization was performed at $121^{\circ} \mathrm{C}$ at $1 \mathrm{~atm}$ in the autoclave.

\subsubsection{Screening with Nile red}

Microorganisms were inoculated in a non-PHA production medium (LB), in a nitrogen-limited PHA production medium, $0.1 \mathrm{~N} \mathrm{M63} \mathrm{(de} \mathrm{Eugenio} \mathrm{et} \mathrm{al.,} \mathrm{2010)} \mathrm{with} 20 \mathrm{~g} \mathrm{I}^{-1}$ glucose or $12 \mathrm{~g} \mathrm{l}^{-1}$ lactose and in a medium prepared by diluting whey or permeate to a lactose concentration of $12 \mathrm{~g} \mathrm{l}^{-1}$. The fluorescence spectrometer used was Hitachi F7000 con $\lambda_{\text {excitation }}=545 \mathrm{~nm}$ and $\lambda_{\text {emission }}=598 \mathrm{~nm}$. The protocol was adapted from a simple and highly sensitive method to detect PHA from growing colonies (Spiekermann et al., 1999, Cruz et al., 2016). Assays were performed in multiwell plates with volume of $300 \mu \mathrm{l}$ and incubating at $30^{\circ} \mathrm{C}$ and $500 \mathrm{rpm}$ for 24 hours. The initial $O D_{600}$ of the cultures was set at 0.3 and the $O D_{600}$ at 24 hours of each strain was adjusted to the lowest $\mathrm{OD}_{600}$ obtained to normalized cell densities for RFU measurements. Then, to each well $2 \mu \mathrm{l}$ of a solution of $0.1 \mathrm{~g}$ Nile red per liter of DMSO was added and fluorescence was assessed in multiwell black plates after 15 min of incubation and compared with the reading taken without the dye.

\subsubsection{Statistical Design of Experiments}

A Design of Experiments (DOE) technique was used to test the relative importance of medium components and environmental factors on PHA production. Results of the micro-reactor assays were obtained and analyzed employing the Taguchi method, which is based on an orthogonal fractionated factorial design methodology. The application of this methodology results in a dramatic reduction of the number of experiments to be performed (Rao et al., 2008; Velasco et al., 2017).

\subsubsection{In silico analysis}

For the identification of PHA producing microorganisms from lactose, the BLAST (Basic Local Alignment Search Tool) program was used. BLAST finds regions of similarity between biological 
sequences. The program compares nucleotide or protein sequences to sequence databases and calculates the statistical significance (Mount, 2007).

\subsection{Results and discussion}

\subsubsection{In silico identification of PHA-producing microorganisms from lactose.}

In silico bioprospecting was performed generating, in a first step, a list of organisms described in literature with the ability to produce PHA and reported $\beta$-galactosidase activity (Figure 1 ).

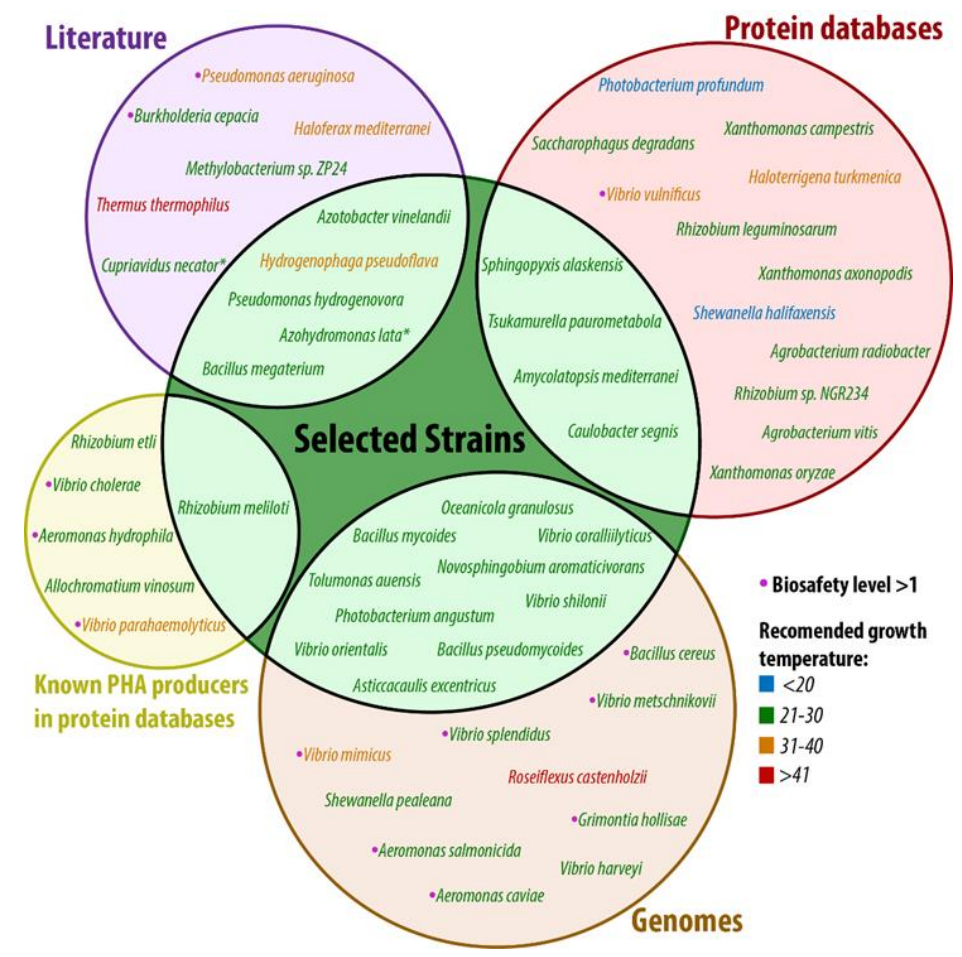

Figure 1. In silico prospecting for PHA producers with beta-galactosidase activity. A list of bacteria with information related with recommended growth temperature (name color) and biosafety level (pink dots) was classified according to the different in silico screening protocols.

Another group of microorganisms was listed based on BLAST searches using E. coli $\beta$ galactosidase protein sequence (NP_414878) as prototype enzyme for hydrolyzing lactose, towards bibliographically studied PHA producers with sequenced genomes. Subsequently, E. coli $\beta$-galactosidase protein sequence and prototypic PHA polymerase protein sequences belonging to the four described types (Table 1; Pettinari et al., 2001; Rehm, 2003; Valappil et al., 2007; Tsuge et al., 2015 ) were used to perform BLAST searches in the Uniprot database. Those organisms with positive hits in both searches were also selected. 
Table 1. Genes used for in silico searching potential strains for PHA production from whey.

\begin{tabular}{lll}
\hline Gene & Organism & Accesion number \\
\hline B- galactosidase (lacZ) & Escherichia coli K12 & NP_414878 \\
PHA polymerase Type I $(p h a C)$ & Ralstonia eutropha & WP_011615085 \\
PHA polymerase Type II $(p h a C l)$ & Pseudomonas putida KT2440 & WP_010955566 \\
PHA polymerase Type II (phaCII) & Pseudomonas putida KT2440 & WP_010955568 \\
PHA polymerase Type III $(p h a C)$ & Allochromatium vinosum & WP_012969309; WP_012969310 \\
PHA polymerase Type IV $(p h a C)$ & Bacillus megaterium & WP_013055939; WP_034653582 \\
\hline
\end{tabular}

Finally, prototypic protein sequences were used to perform Tblastn searches against nucleotide sequences in the GeneBank database and organisms with both putative functions were selected. All the selected strains characteristics were manually revised and data on culture conditions and biosafety level was retrieved for each case. Thus, 42 potential PHAproducing strains with the ability to hydrolyze lactose were identified. We discarded from the list all those strains described as pathogenic or those requiring growth conditions difficult to reproduce on an industrial scale due to special requirements, such as vitamins or high temperatures (Table 2).

Table 2. Microorganisms from the literature and in silico search for PHA production using whey.

\begin{tabular}{|c|c|c|c|c|c|}
\hline Species & Strain & $\begin{array}{l}\text { Putative } \\
\text { Polymerase }\end{array}$ & $\begin{array}{l}\text { Polymerase } \\
\text { Acc. Number }\end{array}$ & $\begin{array}{l}\beta \text {-Galactosidase } \\
\text { Acc. Number }\end{array}$ & Reference \\
\hline Azohydromonas lata & DSM 1123 & I & WP_066338481 & -- & Baei et al. (2010) \\
\hline $\begin{array}{l}\text { Amycolatopsis } \\
\text { mediterranei }\end{array}$ & DSM 43304 & II & WP_013228250 & WP_013226436 & Verma et al. (2011) \\
\hline \multirow{3}{*}{ Asticcacaulis excentricus } & DSM 4724 & 1 & WP_013480283 & WP_013481046 & \multirow{3}{*}{$\begin{array}{l}\text { Skerman et al. } \\
(1980)\end{array}$} \\
\hline & & & & WP_013480849 & \\
\hline & & & & WP_013478732 & \\
\hline Azotobacter vinelandii & DSM 2289 & 1 & WP_012700949 & -- & Koller et al. (2007) \\
\hline \multirow{2}{*}{ Bacillus megaterium } & \multirow[t]{2}{*}{ DSM 90} & \multirow[t]{2}{*}{ IV } & WP_013055939 & \multirow[t]{2}{*}{--} & \multirow{2}{*}{ Chen et al., (1991) } \\
\hline & & & WP_034653582 & & \\
\hline Bacillus mycoides & СЕCT 4128T & IV & WP_002011573 & WP_033798304 & Borah et al. (2002) \\
\hline Bacillus pseudomycoides & CECT 7065T & IV & WP_003196066 & WP_033799124 & Zwick et al. (2012) \\
\hline Caulobacter segnis & DSM 29236 & I & WP_041538528 & WP_013078956 & $\begin{array}{l}\text { Urakami et al. } \\
(1990)\end{array}$ \\
\hline $\begin{array}{l}\text { Hydrogenophaga } \\
\text { pseudoflava }\end{array}$ & DSM 1034 & 1 & -- & -- & Koller et al. (2007) \\
\hline \multirow{2}{*}{$\begin{array}{l}\text { Novosphingobium } \\
\text { aromaticivorans }\end{array}$} & \multirow[t]{2}{*}{ DSM 12444} & \multirow[t]{2}{*}{ I, IV } & WP_041549985 & \multirow[t]{2}{*}{ WP_011446066 } & \multirow{2}{*}{$\begin{array}{l}\text { Takeuchi et al. } \\
\text { (2001) }\end{array}$} \\
\hline & & & WP_011906798 & & \\
\hline Oceanicola granulosus & DSM 15982 & 1 & WP_040614877 & WP_007256669 & $\begin{array}{l}\text { Cho \& Giovannoni } \\
(2004)\end{array}$ \\
\hline
\end{tabular}


Experimental work and results - Chapter I

\begin{tabular}{|c|c|c|c|c|c|}
\hline $\begin{array}{l}\text { Photobacterium } \\
\text { angustum }\end{array}$ & DSM 19184 & ॥ & WP_045149949 & WP_045132314 & $\begin{array}{l}\text { Reichelt et al. } \\
\text { (1976) }\end{array}$ \\
\hline $\begin{array}{l}\text { Pseudomonas } \\
\text { hydrogenovora }\end{array}$ & DSM 1749 & I & -- & -- & Koller et al. (2008) \\
\hline Rhizobium meliloti & CECT 4114T & III & WP_027993898 & WP_027991400 & $\begin{array}{l}\text { Tombolini et al. } \\
\text { (1995) }\end{array}$ \\
\hline Sphingopyxis alaskensis & DSM 13593 & I & WP_041383587 & WP_011541322 & Lauro et al. (2009) \\
\hline Tolumonas auensis & DSM 9187 & I & WP_049759190 & WP_015879948 & $\begin{array}{l}\text { Chertkov et al. } \\
\text { (2011) }\end{array}$ \\
\hline $\begin{array}{l}\text { Tsukamurella } \\
\text { paurometabola }\end{array}$ & CECT 3055 T & II & WP_013128530 & WP_013125671 & Munk et al. (2011) \\
\hline Vibrio coralliilyticus & DSM 19607 & I & WP_006961110 & WP_039952109 & $\begin{array}{l}\text { Ushijima et al. } \\
\text { (2014) }\end{array}$ \\
\hline Vibrio orientalis & DSM 19136 & I & WP_004411639 & WP_004413027 & Yang et al. (1983) \\
\hline \multirow[t]{3}{*}{ Vibrio shilonii } & DSM 13774 & I & WP_006072398 & WP_006071939 & \multirow{3}{*}{$\begin{array}{l}\text { Kushmaro et al. } \\
\text { (2001) }\end{array}$} \\
\hline & & & & WP_006070128 & \\
\hline & & & & WP_031493251 & \\
\hline
\end{tabular}

\subsubsection{Characterization of the whey and evaluation of PHA production from lactose.}

Firstly, the whey and permeate composition was determined. The term "whey" refers to the liquid fraction of the milk that is separated from the curd during cheese production, whereas "permeate" is produced when protein is removed from the whey as so called "retentate" fraction. We analyzed lactose content, lactic acid, protein, $\mathrm{pH}$, etc., and the results are shown in Table 3. The results confirmed that it has the expected composition for whey (Spalatelu, 2012; Fernandez-Gutierrez, 2017) which makes it a good source of nutrients for the growth of microorganisms and suitable to evaluate the production of PHA with the selected strains. Additionally, the composition (\% wt) of the whey according to the elemental analysis was determined as follows: $30.05 \%$ carbon, $6.65 \%$ hydrogen, $1.90 \%$ nitrogen and $61.4 \%$ oxygen.

Table 3. Characterization of whey and permeate to be employed in the formulation of culture media for PHA production. May or may not contain true protein.

\begin{tabular}{|c|c|c|}
\hline & Whey & Permeate \\
\hline [Lactose] $\mathrm{g} \mathrm{I}^{-1}$ & $38 \pm 1.5$ & $56 \pm 1.2$ \\
\hline [Lactic acid] $\mathrm{g}^{-1}$ & $0.8 \pm 0.2$ & $0.1 \pm 0.05$ \\
\hline [Citric acid] g I $^{-1}$ & $0.7 \pm 0.1$ & $0.1 \pm 0.02$ \\
\hline [Protein] $\mathrm{g} \mathrm{I}^{-1}$ & $6.7 \pm 0.5$ & $3.2 \pm 0.5^{*}$ \\
\hline [Fat] $\mathrm{g} \mathrm{I}^{-1}$ & $4.0 \pm 0.3$ & $0.1 \pm 0.01$ \\
\hline Ash (\%) & $0.5 \pm 0.1$ & $0.6 \pm 0.06$ \\
\hline Total Solids (\%) & $6.5 \pm 0.4$ & $5.5 \pm 0.8$ \\
\hline $\mathrm{pH}$ & $6.6 \pm 0.1$ & $6.2 \pm 0.1$ \\
\hline
\end{tabular}

*Non protein nitrogen included in this value. 
It was necessary to develop a method to allow a rapid estimation of the PHA accumulating abilities of a large number of strains and whereby PHA-producing bacteria could be quickly distinguished from non-producing bacteria. The protocol developed is based on staining of the PHA with Nile red as pre-screening until analysis confirmation by GC. Nile red binds to hydrophobic inclusions within the cell including the PHA. Fluorescence increases in correlation with an increase in the amount of accumulated polymer. This method compares the fluorescence of Nile red-stained cells in an environment that does not produce PHA with the fluorescence in a medium that promotes PHA production (Spiekerman et al., 1999). Pseudomonas putida KT2442 was used to test the effectiveness of Nile red staining for being a good PHA producer and Escherichia coli DH5 $\alpha$ (ATCC 11303) as a negative control for being non PHA-producing strain (Solaiman, 2000; Prieto et al., 2007). The non-production conditions were set with LB medium whereas PHA accumulation conditions were tested using three different media; $0.1 \mathrm{~N}$ M63 medium with glucose or lactose as carbon sources to compare with diluted whey and permeate as culture medium (see Experimental procedures for details). Relative fluorescens units (RFU) measurements were taken after 24 hours of incubation because it was sufficient time to evaluate the growth and production of PHA considering the amount of nitrogen source available in the culture media selected for the trial. In addition, measuring the RFU at 48 hours of incubation showed no improvement with any of the strains. The results of the screening based on Nile red staining are shown in Table 4. Seawater isolated strains such as Oceanicola granulosus DSM 15982, Photobacterium angustum DSM 19184, Vibrio coralliilyticus DSM 19607, Vibrio orientalis DSM 19136 and Vibrio shilonii DSM 13774 showed very slow growth in the culture media selected for the experiment. Most of the strains grew in LB, whey and/or permeate and not in the medium $0.1 \mathrm{~N} \mathrm{M63}$ due to more complex nutritional requirements. Some strains were able to accumulate PHA in LB medium or using the fatty acids and/or proteins of the whey as a carbon source.

However, to continue with the selection of strains, the results obtained with whey were analyzed separately, taking into account that using the crude substrate is the best option against any type of pretreatment. Therefore, the percentage of relative fluorescence units (\%RFU) was calculated from the difference between the values of RFU before and after adding Nile red and taking as reference that value for E. coli $\mathrm{DH} 5 \alpha$ in whey as negative control. Figure 2 shows the strains in which there was accumulation of PHA according to the test. Pseudomonas putida KT2442 does not consume lactose, but it accumulated PHA from other carbon sources contained in the whey, presumably from fatty acids. Strains with growth difficulties, with special growing conditions or with complex nutritional requirements were 
discarded. This is the case of the marine strains or strains that need the addition of vitamins or complex carbon sources in the culture medium, such as Azohydromonas lata DSM 1123, Novosphingobium aromaticivorans DSM 12444 or Tolumonas auensis DSM 9187. In general, the more complex a culture medium is and the more extreme the growth conditions of a microorganism are, the greater the costs for scaling-up the process (Koller, 2017).

Table 4. Results of screening strains based on Nile red staining method. (Average of 4 measures).

\begin{tabular}{|c|c|c|c|c|c|}
\hline Strain & $O_{600}$ & $\mathrm{~V}_{\text {sample }}(\mu \mathrm{L})$ & Medium & RFU No NR & RFU With NR \\
\hline $\begin{array}{l}\text { Asticcacaulis excentricus } \\
\text { DSM } 4724\end{array}$ & 0.59 & 300 & Whey & 2.51 & 27.4 \\
\hline \multirow{5}{*}{$\begin{array}{l}\text { Amycolatopsis mediterranei DSM } \\
43304\end{array}$} & 0.09 & 300 & M63-G & 3.09 & 4.38 \\
\hline & 0.14 & 300 & M63-L & 2.74 & 4.41 \\
\hline & 0.03 & 300 & LB & 3.10 & 5.48 \\
\hline & 0.07 & 300 & Whey & 2.64 & 24.3 \\
\hline & 0.00 & 300 & Perm. & 2.09 & 4.95 \\
\hline \multirow{3}{*}{$\begin{array}{l}\text { Azotobacter vinelandii } \\
\text { DSM } 2289\end{array}$} & 0.25 & 300 & LB & 2.82 & 3.48 \\
\hline & 0.41 & 182 & Whey & 3.69 & 21.3 \\
\hline & 0.51 & 119 & M63-G & 2.70 & 4.42 \\
\hline \multirow{3}{*}{$\begin{array}{l}\text { Bacillus megaterium } \\
\text { DSM } 90\end{array}$} & 2.70 & 23 & LB & 4.08 & 5.82 \\
\hline & 1.69 & 36 & Whey & 3.77 & 16.9 \\
\hline & 0.20 & 300 & Perm. & 2.34 & 7.14 \\
\hline \multirow{4}{*}{$\begin{array}{l}\text { Bacillus mycoides } \\
\text { CECT } 4128 \mathrm{~T}\end{array}$} & 0.26 & 266 & M63-G & 2.81 & 5.68 \\
\hline & 0.23 & 300 & M63-L & 2.77 & 3.80 \\
\hline & 1.26 & 55 & LB & 7.96 & 8.90 \\
\hline & 0.57 & 120 & Whey & 3.31 & 15.0 \\
\hline \multirow{5}{*}{$\begin{array}{l}\text { Bacillus pseudomycoides } \\
\text { CECT 7065T }\end{array}$} & 0.13 & 300 & M63-G & 2.75 & 4.71 \\
\hline & 0.11 & 300 & M63-L & 3.00 & 3.52 \\
\hline & 0.97 & 48 & LB & 3.76 & 5.24 \\
\hline & 0.46 & 103 & Whey & 4.44 & 16.7 \\
\hline & 0.16 & 300 & Perm. & 2.36 & 5.73 \\
\hline \multirow{4}{*}{$\begin{array}{l}\text { Caulobacter segnis } \\
\text { DSM } 29236\end{array}$} & 0.64 & 247 & M63-G & 3.15 & 4.39 \\
\hline & 0.52 & 300 & M63-L & 2.35 & 5.88 \\
\hline & 2.18 & 72 & LB & 4.02 & 11.2 \\
\hline & 1.48 & 106 & Whey & 4.28 & 27.6 \\
\hline \multirow{3}{*}{$\begin{array}{l}\text { Escherichia coli } \\
\text { ATCC } 11303\end{array}$} & 3.40 & 26 & LB & 3.49 & 4.42 \\
\hline & 1.42 & 62 & Whey & 2.37 & 10.1 \\
\hline & 0.29 & 300 & Perm. & 1.94 & 3.50 \\
\hline \multirow{3}{*}{$\begin{array}{l}\text { Hydrogenophaga pseudoflava } \\
\text { DSM } 1034\end{array}$} & 2.47 & 32 & LB & 3.59 & 18.3 \\
\hline & 0.69 & 115 & Whey & 3.55 & 34.2 \\
\hline & 0.26 & 300 & Perm. & 1.72 & 5.99 \\
\hline \multirow{3}{*}{$\begin{array}{l}\text { Pseudomonas } \\
\text { hydrogenovora } \\
\text { DSM } 1749\end{array}$} & 0.39 & 166 & LB & 3.55 & 4.87 \\
\hline & 0.55 & 120 & Whey & 3.79 & 22.1 \\
\hline & 0.22 & 300 & Perm. & 2.61 & 4.11 \\
\hline \multirow{4}{*}{$\begin{array}{l}\text { Pseudomonas } \\
\text { putida KT2442 }\end{array}$} & 0.51 & 138 & M63-G & 3.88 & 4.55 \\
\hline & 3.81 & 19 & LB & 4.18 & 5.76 \\
\hline & 0.99 & 72 & Whey & 7.55 & 28.8 \\
\hline & 0.24 & 300 & Perm. & 2.24 & 5.04 \\
\hline \multirow{3}{*}{$\begin{array}{l}\text { Rhizobium Meliloti } \\
\text { CECT } 4114 \mathrm{~T}\end{array}$} & 0.38 & 182 & Perm. & 3.75 & 10.7 \\
\hline & 0.44 & 115 & LB & 3.92 & 4.98 \\
\hline & 0.17 & 300 & Whey & 2.10 & 21.2 \\
\hline \multirow{3}{*}{$\begin{array}{l}\text { Sphingopyxis alaskensis } \\
\text { DMS } 13593\end{array}$} & 1.51 & 37 & LB & 4.31 & 6.74 \\
\hline & 0.99 & 57 & Whey & 3.74 & 21.3 \\
\hline & 0.19 & 300 & Perm. & 2.53 & 4.13 \\
\hline
\end{tabular}

NR: Nile Red, M63-G: $0.1 \mathrm{~N} \mathrm{M63} \mathrm{medium} \mathrm{with} \mathrm{glucose} 20 \mathrm{~g} \mathrm{I}^{-1}$, M63-L: $0.1 \mathrm{~N} \mathrm{M63} \mathrm{medium} \mathrm{with} \mathrm{lactose} 12 \mathrm{~g} \mathrm{I}^{-1}$, Perm.: Permeate. Data obtained on relative fluorescence units (RFU). 


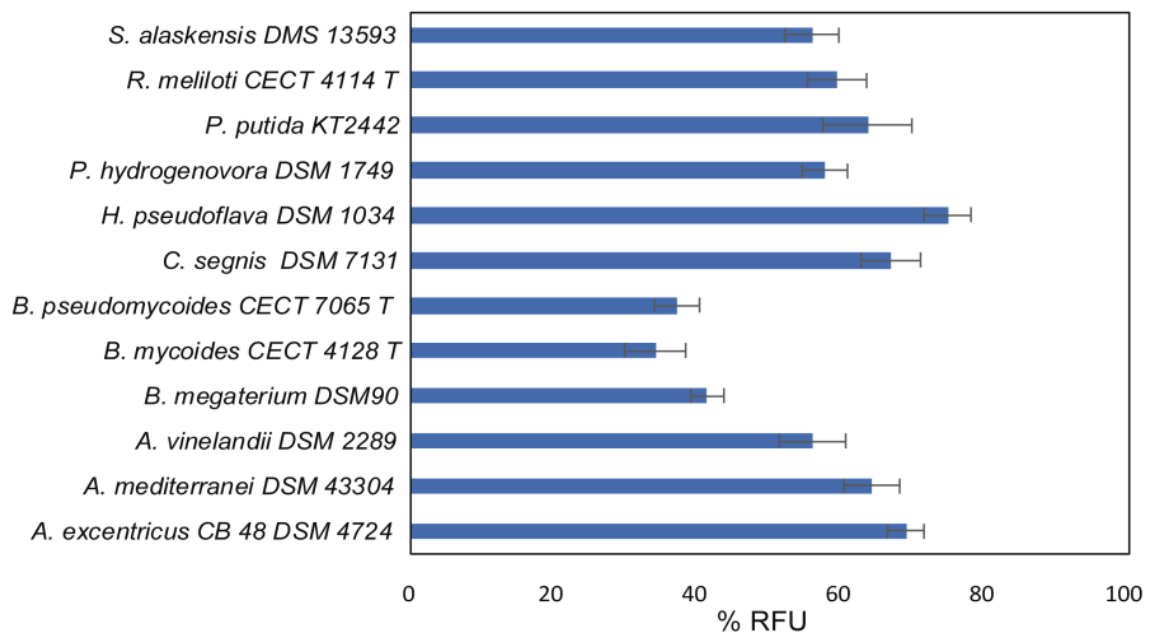

Figure 2. Bacterial strains selected from Nile-red assays. $\% R F U=\Delta R F U_{\text {Strain }}-\Delta R F U_{E . c o l i} / \Delta R F U_{S t r a i n}$

Finally, six strains were selected for further testing and quantification of PHA production: Amycolatopsis mediterranei DSM 43304, Caulobacter segnis DSM 29236, Pseudomonas hydrogenovora DSM 1749 (today: Paraburkholderia fungorum, according to www.dsmz.de, Coenye et al., 2001), Bacillus megaterium DSM 90 and Hydrogenophaga pseudoflava DSM 1034. The following assays were performed in MM1 medium. In tests with diluted whey to lactose $12 \mathrm{~g} \mathrm{I}^{-1}$, sugar consumption did not exceed 10\% (Table 5). Hydrogenophaga pseudoflava, P. hydrogenovora and B. megaterium are well known PHA producers (Koller et al., 2008; Obruca et al., 2009). The production of PHA by A. mediterranei and C. segnis had not been described before. It was decided to continue with C. segnis DSM 29236 because of its novelty and because it appeared to be the producer with the highest capacity according to the preliminary results.

Table 5. Testing and quantification of PHA accumulation with the five strains selected from Nile-Red screening. Assays performed in MM1 medium with diluted whey to lactose $12 \mathrm{~g} \mathrm{I}^{-1}$.

\begin{tabular}{lcc}
\hline Strain & \%PHB & \% Lactose consumed \\
\hline A. mediterranei DSM 43304 & $6.7 \pm 1.3$ & $4.5 \pm 0.8$ \\
B. megaterium DSM 90 & $11.9 \pm 2.3$ & $8.2 \pm 1.1$ \\
B. mycoides CECT 4128 & $4.3 \pm 1.6$ & $5.4 \pm 0.7$ \\
C. segnis DSM 29236 & $7.8 \pm 1.8$ & $4.8 \pm 0.9$ \\
H. pseudoflava DSM 1034 & $2.9 \pm 0.7$ & $2.4 \pm 0.4$ \\
P. hydrogenovora DSM 1749 & $7.4 \pm 0.6$ & $6.4 \pm 0.3$ \\
\hline
\end{tabular}

\subsubsection{Selection of optimal fermentation process conditions for PHA production.}

The PHA produced by C. segnis DSM 29236 was identified as poly-3-hydroxybutyrate (PHB) (Figure 3). The available sequence of the PHA polymerase found in the published $C$. segnis 
genome shows a class I poly(R)-hydroxyalkanoic acid synthase (accession number WP_0415385280). For class I PHA polymerases, Ralstonia eutropha is considered as the model strain (Rehm, 2003). For R. eutropha and related species to C. segnis such as Caulobacter crescentus, PHA metabolism involves the synthesis of acetyl-CoA from sugars and its subsequent conversion into PHB (Farinha, 2009; Buckley, 2013). Different culture media were used to optimize PHB production from whey with C. segnis DSM 29236: diluted whey, MM2, MM3, MM4, MM5 and MM6, with an initial lactose concentration of $12 \mathrm{gl}^{-1}$. The highest PHB titer was obtained with medium MM3. The strain produced $0.09 \mathrm{~g} \mathrm{I}^{-1}$ of PHB with a $13.4 \%$ accumulation of its cell dry weight (CDW) (Figure 4) but lactose was not totally consumed. This medium contains a minimum amount of nitrogen source and contains phosphates, unlike the MM4 medium.

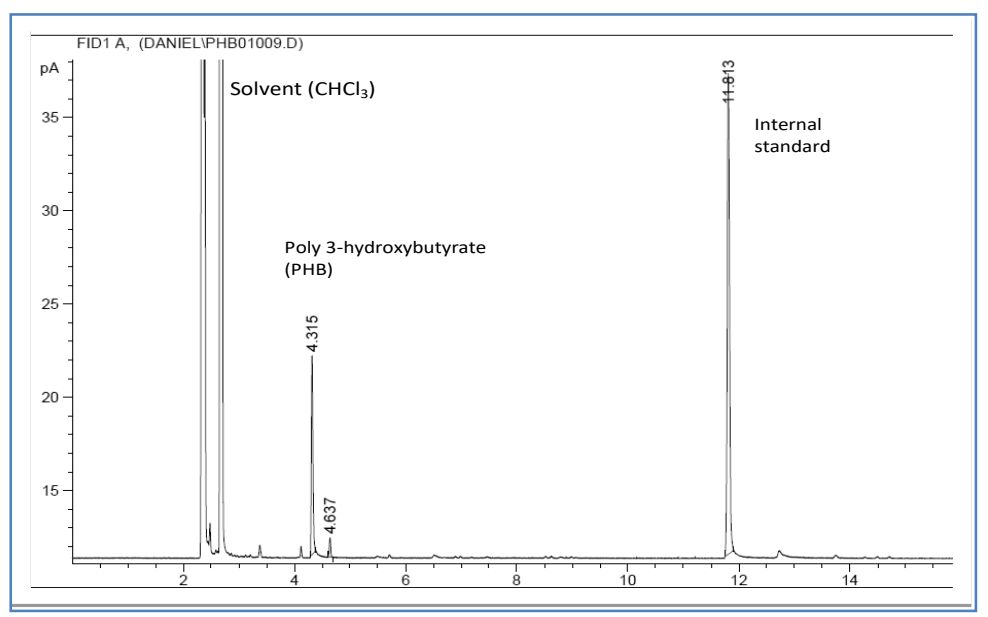

Figure 3. Chromatogram of PHA sample showing internal standard (methyl benzoate) and PHB monomers as 3-hydroxymethylesters in the Caulobacter segnis DSM 29236 dry biomass

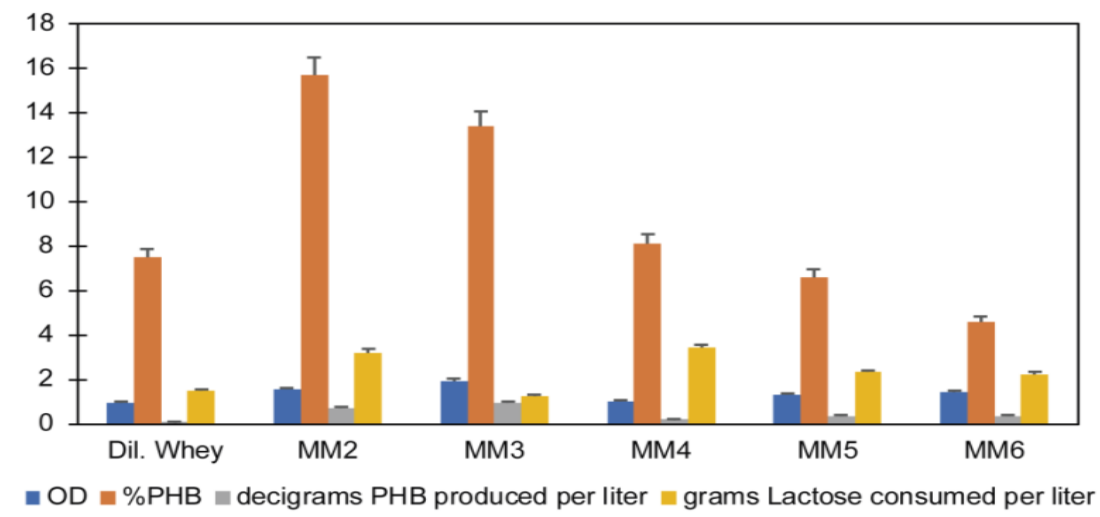

Figure 4. Optimization of PHB production from whey with Caulobacter segnis DSM 29236. Different media were used: MM2, MM3, MM4, MM5 and MM6, with an initial lactose concentration of $12 \mathrm{gl}^{-1}$. 
Therefore the process was further optimized in micro-reactor assays with 24 wells of $3 \mathrm{ml}$ reaction volume. The temperature, $\mathrm{pH}$ and dissolved oxygen concentration were monitored and controlled via sensors in each well. A factorial design of experiments based on the orthogonal matrix method, whereby representative results can be obtained using some chosen variables, fixed at different levels, with the minimum possible number of experiments was used. This was intended to optimize both PHB production and lactose consumption starting with the simplest medium, MM3, the medium for which the highest yields had been obtained considering that the production of PHB is directly related to the composition of the medium and the oxygen saturation (Yang et al., 2010). Therefore, it was decided to add nitrogen source $\left(\mathrm{NH}_{4}{ }^{+}\right.$from $\left.\left(\mathrm{NH}_{4}\right)_{2} \mathrm{SO}_{4}\right)$, magnesium $\left(\mathrm{Mg}^{2+}\right.$ from $\left.\mathrm{MgSO}_{4}\right)$ and phosphates $\left(\mathrm{PO}_{4}{ }^{3-}\right.$ from buffer) to the medium and also test variations in oxygen saturation (Table 6). Following the Taguchi method, experiments were designed with the L9 orthogonal array whereby 9 experiments in duplicates with 4 factors were run at 3 levels (Khosravi-Darani et al., 2004; Wojtusik et al., 2015). The amount of PHA produced by C. segnis DSM 29236 was not increased considerably and lactose consumption rates were not entirely satisfactory using medium MM3 at these conditions (Table 6, exp. 1-9). However, results of the assays where analyzed by Taguchi method taking PHB titer as a response since this is an intracellular product intrinsically related with cell growth. Components of the medium such as nitrogen, magnesium or phosphate play an essential role in the balance between growth and PHA accumulated by the strain (Bozorg et al., 2015). The effect of the variables selected in experimental design is shown in Figure 5. In this case, the production of PHB tends to decrease when less amount of nitrogen source is added in the culture medium. According to literature, the limitation in nitrogen source increases the accumulation of PHA, but the accumulation of PHB remains around $10 \%$ practically in all trials. Therefore, the increase in the production of PHB is a consequence of an increase in cell growth due to the greater availability of nitrogen source in the culture medium. On the other hand, the effect of magnesium salt addition is not determinant. In terms of oxygen saturation and as expected, the production of PHB is increases when there is oxygen limitation in the culture; therefore, it is important to control this variable using this strain in the same way as described for other PHA producing strains (Kshirsagar et al., 2012). Regarding the source of phosphate, there are also previous studies that show how the limitation in phosphate source improves the yields of PHA production, especially for cultures with high cell density (Lee et al., 2000). However, under the conditions tested, it is observed that at concentrations below $20 \mathrm{mM}$ of phosphate the production of PHB decreases considerably, thus this is a fundamental variable for the growth of the strain and the production of PHB. 
Table 6. L9 matrix of the experimental design for the optimization of the PHA production using the simplest culture medium (MM3) and the microreactor (duplicate results).

\begin{tabular}{|c|c|c|c|c|c|c|c|c|}
\hline \multirow[b]{2}{*}{ Run } & \multicolumn{4}{|c|}{ Variables (Factors) } & \multicolumn{4}{|l|}{ Results } \\
\hline & $\begin{array}{l}\mathrm{NH}_{4}^{+} \\
(\mathrm{mM})\end{array}$ & $\begin{array}{l}\mathrm{Mg}^{2+} \\
(\mathrm{mM})\end{array}$ & $\begin{array}{l}\mathrm{O}_{2} \\
(\%)\end{array}$ & $\begin{array}{l}\mathrm{PO}_{4}^{3-} \\
(\mathrm{mM}) \\
\end{array}$ & $O D_{\text {Final }}$ & $\begin{array}{l}\text { PHB } \\
(\% w t) \\
\end{array}$ & $\begin{array}{l}\text { PHB } \\
\left(\mathrm{g} \mathrm{I}^{-1}\right)\end{array}$ & $\begin{array}{l}\text { Lactose } \\
\left(\mathrm{g} \mathrm{I}^{-1}\right)\end{array}$ \\
\hline 1 & $0.0(1)$ & $0.0(1)$ & $10(1)$ & $10(1)$ & $2.63 \pm 0.03$ & $11.1 \pm 0.3$ & $0.078 \pm 0.003$ & $1.56 \pm 0.02$ \\
\hline 2 & $0.0(1)$ & $3.5(2)$ & $20(2)$ & $20(2)$ & $2.79 \pm 0.02$ & $9.8 \pm 0.5$ & $0.118 \pm 0.052$ & $1.28 \pm 0.15$ \\
\hline 3 & $0.0(1)$ & $7.0(3)$ & $30(3)$ & $30(3)$ & $2.96 \pm 0.05$ & $10.1 \pm 0.2$ & $0.135 \pm 0.038$ & $1.37 \pm 0.05$ \\
\hline 4 & $8.5(2)$ & $0.0(1)$ & $10(1)$ & $30(3)$ & $4.89 \pm 0.11$ & $8.7 \pm 0.4$ & $0.233 \pm 0.011$ & $1.82 \pm 0.17$ \\
\hline 5 & $8.5(2)$ & $3.5(2)$ & $30(3)$ & $10(1)$ & $4.69 \pm 0.09$ & b.l.d & $0.029 \pm 0.016$ & $1.90 \pm 0.22$ \\
\hline 6 & $8.5(2)$ & $7.0(3)$ & $20(2)$ & $20(2)$ & $5.99 \pm 0.22$ & $8.7 \pm 0.7$ & $0.251 \pm 0.038$ & $1.70 \pm 0.13$ \\
\hline 7 & $28(3)$ & $0.0(1)$ & $30(3)$ & $20(2)$ & $5.20 \pm 0.07$ & $8.3 \pm 0.8$ & $0.229 \pm 0.052$ & n.d. \\
\hline 8 & $28(3)$ & $3.5(2)$ & $10(1)$ & $30(3)$ & $5.84 \pm 0.04$ & $8.7 \pm 0.7$ & $0.240 \pm 0.054$ & $2.14 \pm 0.25$ \\
\hline 9 & $28(3)$ & $7.0(3)$ & $20(2)$ & $10(1)$ & $5.35 \pm 0.13$ & b.l.d & $0.087 \pm 0.055$ & $1.69 \pm 0.08$ \\
\hline \multicolumn{9}{|c|}{ Additional assays } \\
\hline 10 & 0 & 0 & 20 & 25 & $2.74 \pm 0.03$ & $11.9 \pm 0.6$ & $0.124 \pm 0.032$ & $1.22 \pm 0.19$ \\
\hline 11 & 0 & 0 & 20 & 25 & $4.13 \pm 0.12$ & b.l.d & $0.080 \pm 0.025$ & n.d. \\
\hline 12 & 15 & 0 & 20 & 25 & $6.23 \pm 0.09$ & $7.4 \pm 0.3$ & $0.222 \pm 0.043$ & n.d. \\
\hline
\end{tabular}

b.l.d., below of limit of detection

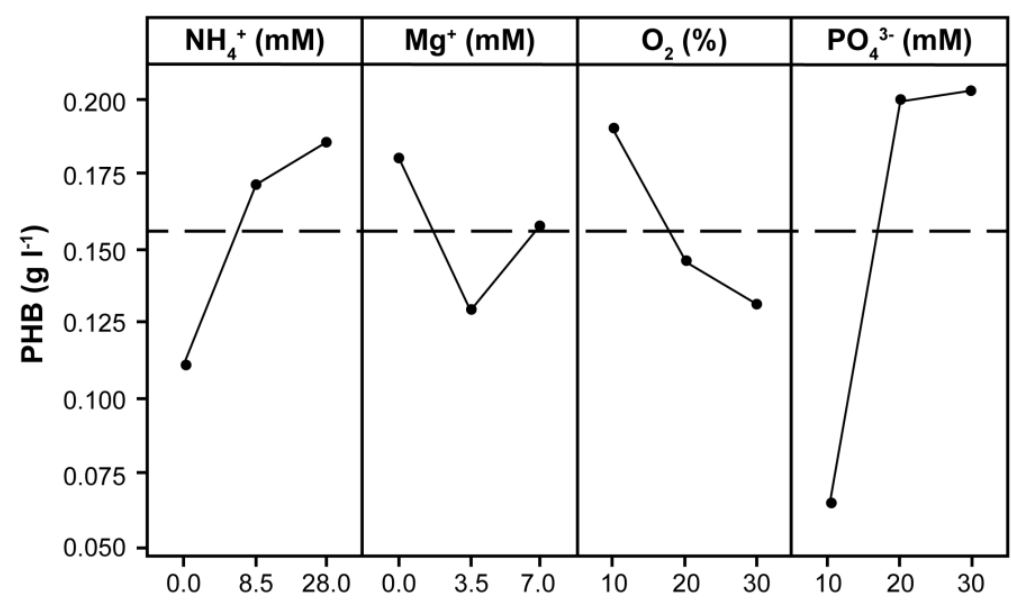

Figure 5. Effect of the variables on the production of PHB by Caulobacter segnis DSM 29236 (main effects). Results were analyzed by Taguchi method considering 4 factors: nitrogen source $\left(\mathrm{NH}_{4}+\right.$ from $\left.\left(\mathrm{NH}_{4}\right)_{2} \mathrm{SO}_{4}\right)$, magnesium $\left(\mathrm{Mg}^{2+}\right.$ from $\left.\mathrm{MgSO}_{4}\right)$, phosphates $\left(\mathrm{PO}_{4}{ }^{3-}\right.$ from buffer) and oxygen saturation and with PHB titer as the response.

Further trials were included: i) a control experiment with the same conditions tested (MM3 unchanged); ii) with added vitamins, and iii) with an intermediate nitrogen concentration (Table 6, exp. 10-12). The results show that neither the addition of vitamins nor increasing the source of nitrogen improves the production of PHA with respect to the control conditions. Subsequent optimization assays were performed in other culture media to try to increase production yields considering the results mentioned above, particularly the $\mathrm{C} / \mathrm{N}$ ratio influence. 
Previous studies of fermentation with whey have shown that the $\mathrm{C} / \mathrm{N}$ ratio is an important factor for the production of PHA. In some cases it was found that PHB production was optimal for a $\mathrm{C} / \mathrm{N}$ ratio of 50 with a consortium of microorganisms (Bosco and Chiampo, 2010), whereas with a strain of $B$. thuringensis, capable of producing appreciable amounts of PHB from whey, an optimal C/N ratio of 8 for PHA accumulation was found (Srividya, 2011; Gowda and Shivakumar, 2014). For this study, C. segnis DSM 29236 experiments were performed by modifying the inorganic nitrogen, phosphates and the amount of whey in the culture media: MM2, MM3, MM6 and MM7. The test conditions corresponding to the most relevant results are shown in Table 7. The $\mathrm{C} / \mathrm{N}$ ratio of whole whey has a value of about 24 taking into account a typical elemental analysis; this is an intermediate value considering the $\mathrm{C} / \mathrm{N}$ ratios mentioned above and it is interesting to avoid pre-treatments such as ultrafiltration or protein precipitation, in order to simplify the process. For the media MM2 and MM3, combinations were made using half the amount of whey, twice the original amount of nitrogen and the original amounts thereof maintaining nitrogen limitations and a $\mathrm{C} / \mathrm{N}$ ratio of around 20 . For the MM6 medium the amounts of phosphate and nitrogen were modified maintaining a $\mathrm{C} / \mathrm{N}$ ratio around 7 except for the MM6c medium which is 14 . The MM7 medium is the medium richest in nitrogen and only the amount of whey added is modified to observe the effects on lactose consumption. As Table 7 shows, the best results were obtained with medium MM3 with the modification $\mathrm{MM} 3 \mathrm{a}$, in which $31.5 \%$ of $\mathrm{PHB}$ was accumulated reaching $1.50 \mathrm{~g} \mathrm{I}^{-1}$ of PHB. Lactose consumption increased considerably compared to previous trials. These conditions favor PHA accumulation as well as lactose consumption and cell growth. On the other hand, these results seem to indicate that a high concentration of phosphate and/or citric acid is detrimental to lactose consumption.

Table 7. Optimization of production of PHA with Caulobacter segnis DSM 29236-modifying culture media MM2, MM3, MM6 and MM7 (triplicate results).

\begin{tabular}{|c|c|c|c|c|c|}
\hline Medium & Modification & $O D_{\text {Final }}$ & $\begin{array}{c}\text { PHB } \\
\text { (\% wt) }\end{array}$ & $\begin{array}{l}\text { PHB } \\
\left(\mathrm{gl}^{-1}\right)\end{array}$ & $\begin{array}{l}\text { \% Lactose } \\
\text { consumed }\end{array}$ \\
\hline MM2a & $0.1 \mathrm{gl}^{-1}\left(\mathrm{NH}_{4}\right)_{2} \mathrm{SO}_{4}, 8 \mathrm{gl}^{-1}$ lactose & $2.99 \pm 0.07$ & $5.9 \pm 1.2$ & $0.14 \pm 0.01$ & $70.8 \pm 2.5$ \\
\hline $\mathrm{MM} 2 \mathrm{~b}$ & $0.1 \mathrm{~g} \mathrm{l}^{-1}\left(\mathrm{NH}_{4}\right)_{2} \mathrm{SO}_{4}, 16 \mathrm{~g} \mathrm{I}^{-1}$ lactose & $5.51 \pm 0.06$ & $8.5 \pm 3.1$ & $0.45 \pm 0.05$ & $63.4 \pm 3.4$ \\
\hline MM3a & $0.1 \mathrm{~g} \mathrm{I}^{-1}\left(\mathrm{NH}_{4}\right)_{2} \mathrm{SO}_{4}, 8 \mathrm{~g} \mathrm{l}^{-1}$ lactose & $5.89 \pm 0.11$ & $31.5 \pm 5.2$ & $1.50 \pm 0.08$ & $74.5 \pm 5.8$ \\
\hline MM3b & $0.2 \mathrm{gl}^{-1}\left(\mathrm{NH}_{4}\right)_{2} \mathrm{SO}_{4}, 8 \mathrm{~g} \mathrm{l}^{-1}$ lactose & $5.52 \pm 0.08$ & $23.1 \pm 4.6$ & $1.04 \pm 0.22$ & $66.5 \pm 6.2$ \\
\hline MM3c & without $\left(\mathrm{NH}_{4}\right)_{2} \mathrm{SO}_{4}, 8 \mathrm{gl}^{-1}$ lactose & $4.05 \pm 0.03$ & $22.4 \pm 2.8$ & $0.78 \pm 0.11$ & $65.0 \pm 4.6$ \\
\hline MM6a & $3.0 \mathrm{gl}^{-1}\left(\mathrm{NH}_{4}\right)_{2} \mathrm{HPO}_{4}, 6.67 \mathrm{~g} \mathrm{I}^{-1} \mathrm{KH}_{2} \mathrm{PO}_{4}$ & $2.41 \pm 0.05$ & $7.4 \pm 1.5$ & $0.15 \pm 0.03$ & $23.6 \pm 5.7$ \\
\hline MM6b & $3.0 \mathrm{~g} \mathrm{I}^{-1}\left(\mathrm{NH}_{4}\right)_{2} \mathrm{HPO}_{4}$, without $\mathrm{KH}_{2} \mathrm{PO}_{4}$ & $3.83 \pm 0.14$ & $12.2 \pm 2.6$ & $0.38 \pm 0.02$ & $36.7 \pm 6.9$ \\
\hline MM6c & $1.0 \mathrm{gl}^{-1}\left(\mathrm{NH}_{4}\right)_{2} \mathrm{HPO}_{4}, 6.67 \mathrm{~g} \mathrm{I}^{-1} \mathrm{KH}_{2} \mathrm{PO}_{4}$ & $3.31 \pm 0.07$ & $9.2 \pm 2.4$ & $0.25 \pm 0.01$ & $42.6 \pm 5.5$ \\
\hline MM6d & $4.0 \mathrm{~g} \mathrm{I}^{-1}\left(\mathrm{NH}_{4}\right)_{2} \mathrm{HPO}_{4}, 6.67 \mathrm{~g} \mathrm{I}^{-1} \mathrm{KH}_{2} \mathrm{PO}_{4}$ & $2.49 \pm 0.05$ & $7.4 \pm 1.7$ & $0.15 \pm 0.04$ & $32.3 \pm 2.3$ \\
\hline MM7a & $16 \mathrm{~g} \mathrm{I}^{-1}$ lactose & $5.02 \pm 0.10$ & $7.7 \pm 2.2$ & $0.43 \pm 0.09$ & $52.7 \pm 4.2$ \\
\hline MM7b & $8 \mathrm{~g}^{-1}$ lactose & $2.69 \pm 0.02$ & $8.8 \pm 1.2$ & $0.20 \pm 0.07$ & $80.9 \pm 3.3$ \\
\hline
\end{tabular}




\subsubsection{PHA production by C. segnis DSM 29236 and related Caulobacter strains from whey.}

Caulobacter are gram negative bacteria with shapes that vary from rods, to fusiform, or vibrioid with asymmetric cell division to minimize competition for resources (Abraham et al., 1999). Caulobacter segnis is closely related to Caulobacter crescentus, which is an aquatic Gram-negative alphaproteobacterium and some strains were already described as PHA producers (Curtis and Brun, 2010; Patel et al., 2015). Two strains of the related species C. crescentus were chosen from the literature to test the highest PHA production capacity of $C$. segnis DSM 29236: C. crescents DSM 4727 and DSM 9893 (Qi and Rehm, 2001; Buckley, 2013). The optimum operating conditions were tested using the mineral culture medium MM3a supplemented with whey as carbon source to produce PHA from lactose. Batch incubation was performed in a flask at $30^{\circ} \mathrm{C}$ and $180 \mathrm{rpm}$. The $\mathrm{pH}$ was set at 7 but it changed freely during the course of fermentation. Figure 6 shows the results obtained from incubations at 48 hours. Strain C. segnis DSM 29236 was superior to C. crescentus strains, confirming that DSM 29236 is a good previously unknown PHA producer. In addition, to date, studies on PHA production with strains of the genus Caulobacter have been performed using glucose as carbon source, but not lactose. As mentioned above, there are few bacteria capable of using lactose directly as a carbon source. Some species of bacteria such as B. megaterium and Methylobacterium sp. ZP24 are able to use whole whey to produce PHB with biopolymer accumulation between 20$40 \%$ of CDW (Table 8), and even recombinant strains such as E. coli CGSC 4401 capable of producing $96.2 \mathrm{gl}^{-1}$ of PHB and accumulating up to $80 \%$ of CDW in fed-batch conditions (Ahn et al., 2000). Results obtained with this strain are quite similar to those obtained so far with previously reported wild type strains; therefore it is a promising candidate for evaluating its PHB production performance in bioreactor under fed-batch conditions.

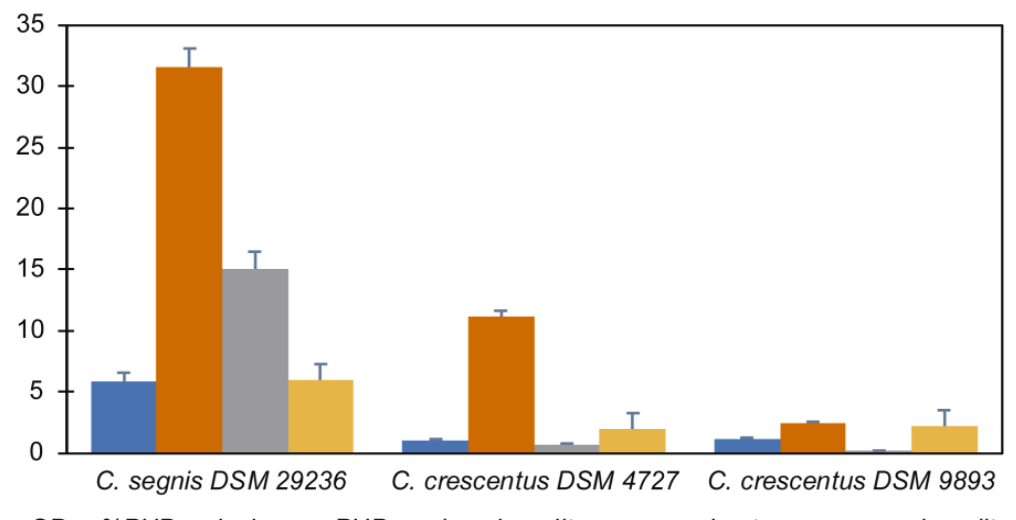

Figure 6. Two strains of the related species $C$. crescentus were chosen to test the highest PHA production capacity of $C$. segnis DSM 29236 using the culture medium MM3a supplemented with whey. 


\subsubsection{Validation of the production of PHB in fed-batch cultures with Caulobacter segnis DSM} 29236

Fed-batch cultures have been used to evaluate the behavior of the strain during PHA production and to optimize the fermentation to try to achieve high cell density cultures. As mentioned before, PHA is an intracellular product, so it is very important to obtain high cell density cultures as a step prior to the industrial scale-up especially using waste streams as substrates (Rodriguez-Perez et al., 2018). A first fermentation was performed using the MM3 medium supplemented with magnesium sulfate and ammonium sulfate to ensure the nutrients needed by the strain during the first phase of the fermentation. Again, the MM3 medium was used as the culture medium with which the strain accumulated the greatest amount of PHB in the previous assays. The results of the experiment are shown in Figure 7. During the experiment, oxygen saturation was decreasing from the beginning of the fermentation until it remained at 30\%. After 15 hours of fermentation the oxygen saturation started to rise gradually, and the lactose concentration was $2.5 \mathrm{~g} \mathrm{l}^{-1}$, so an amount of whey equivalent to $20 \%(100 \mathrm{ml})$ of the batch volume was added. Then the oxygen saturation began to drop again and remained at $30 \%$ while the cell density of the culture continued increasing. At 24 hours a second addition of whey of around $40 \%$ of the initial batch volume $(200 \mathrm{~mL})$ was made and the culture continued to grow and consume lactose. At 40 hours the culture was very viscous and the $\mathrm{pH}$ adjustment with ammonium was changed to sodium hydroxide $5 \mathrm{~N}$ to maintain nitrogen limitation during the last fermentation stage. A final addition of whey equivalent to $40 \%$ of the initial batch was made and the fermentation was finished after 50 hours. Under these conditions the strain achieved an accumulation of PHB of $25 \%$ of its CDW, $4.3 \mathrm{~g} \mathrm{I}^{-1}$ of PHB was obtained and the strain consumed almost all the lactose. The production of PHB obtained with this experiment is about three times higher than the value obtained in flask. In addition, the amounts of whey added during fermentation have diluted the culture considerably, but it has shown that this substrate at high concentration has no inhibitory effects on the strain. However, inhibitory effects are observed when the strain is not adapted to the culture medium and high concentrations of the whey are added from the beginning of the fermentation.

A second fed-batch fermentation experiment was performed to evaluate the production of PHB in a less limited culture medium with more nitrogen and phosphorus sources, and to test the continuous addition of a concentrated solution of whey. For this purpose, the MR medium described by Lee and colleagues (2000) and a 5-fold concentrated whey solution were used to achieve a lactose concentration of about $200 \mathrm{~g} \mathrm{l}^{-1}$. The Figure 8 shows the results of the 
experiment. As in the previous experiment, the oxygen saturation of the culture started to fall since the beginning of the fermentation and at 15 hours the feed of concentrated substrate was activated to maintain the concentration of lactose in the culture at around $5 \mathrm{~g} \mathrm{I}^{-1}$ during the fermentation. The oxygen saturation of the culture was maintained at $30 \%$ during the whole fermentation and the cell density was gradually increasing during the experiment. In a similar way to the previous experiment, the $\mathrm{pH}$ control with ammonium was changed to $\mathrm{NaOH}$ $5 \mathrm{~N}$ at 40 hours of fermentation and the culture showed less viscosity. Finally, an accumulation and PHB concentration of $37 \%$ and $9.25 \mathrm{~g} \mathrm{I}^{-1}$ are obtained, respectively, and the strain has consumed lactose efficiently.

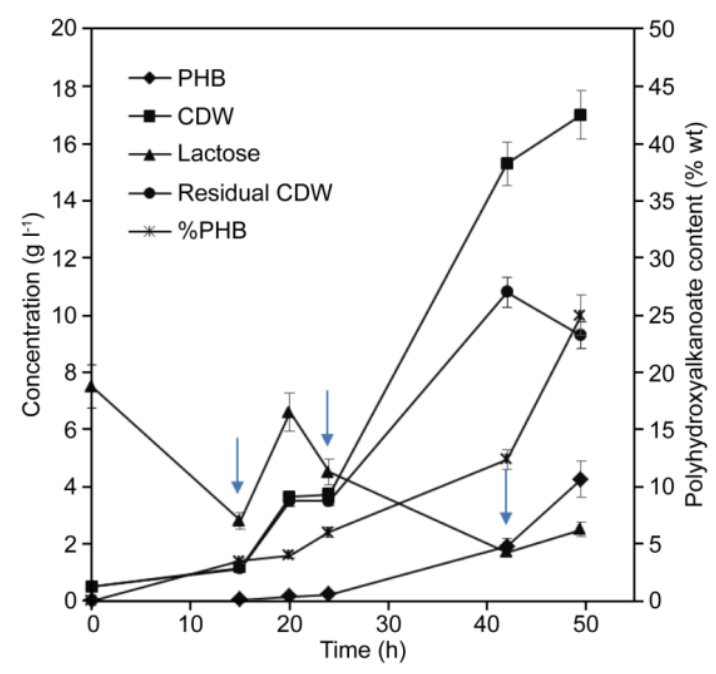

Figure 7. Growth and PHB production by Caulobacter segnis DSM 29236 for the fed-batch fermentation with restricted medium MM3modified.

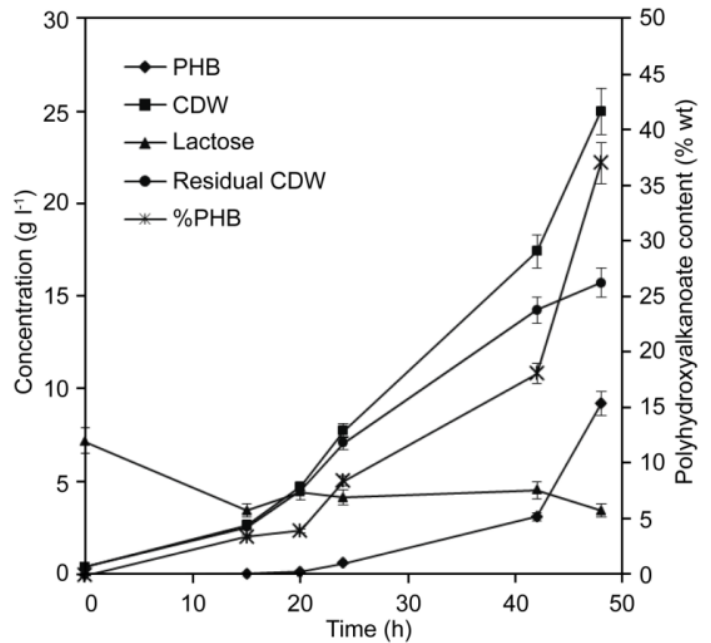

Figure 8. Growth and PHB production by Caulobacter segnis DSM 29236 for the fedbatch fermentation with continuous addition of concentrated whey.

These first fed-batch fermentation experiments constitute the first steps to the scale-up for the production process of PHB with strain C. segnis DSM 29236. The strain has reached PHB concentrations around $10 \mathrm{~g} \mathrm{I}^{-1}$, almost seven times more than the results obtained in the flask cultures. The selection of convenient batch medium and adjusted feeding policy has allowed us to achieve the highest reported PHB concentration for a wild-type microorganism (Table 8). Therefore, the production of PHB has been validated with a wild strain not previously described as producing PHB and it has been demonstrated it suitability as industrial strain. 
Probably the advances in systems and synthetic biology will enable the design and construction of PHA hyperproducing strains (Wang et al., 2014; Chen and Jiang, 2017). For example, cells could be induced for flocculation precipitation followed by induced cell lysis after completing PHA production, and fermentation could be conducted continuously under unsterile conditions using seawater so that PHA production costs would make them competitive with petroleum-based plastics (Martinez et al., 2011; Tan et al., 2011).

Table 8. Production of PHA from whey in shaking flask and bioreactor: overview of literature data.

\begin{tabular}{|c|c|c|c|c|c|c|}
\hline Microorganism & $\begin{array}{l}\text { CDW } \\
\left(\mathrm{gl}^{-1}\right)\end{array}$ & $\begin{array}{l}\text { PHA } \\
\left(\mathrm{g} \mathrm{I}^{-1}\right)\end{array}$ & $\begin{array}{c}\text { PHA } \\
\left(\mathrm{g}^{-1} \mathrm{~h}^{-1}\right)\end{array}$ & $\begin{array}{l}\text { Type of } \\
\text { polymer }\end{array}$ & Device & Reference \\
\hline \multirow[t]{3}{*}{ Azohydromonas lata } & 9,2 & 1,66 & 0,02 & PHBV & Flask & Baei et al. 2010 \\
\hline & 1,51 & 1,28 & 0,11 & PHB & Flask & Berwig et al. 2016 \\
\hline & 1,67 & 0,16 & 0,01 & PHB & Bioreactor & Berwig et al. 2016 \\
\hline Bacillus megaterium CCM 2037 & 2,82 & 1,05 & 0,02 & PHB & Flask & Obruca et al. 2011 \\
\hline \multirow[t]{2}{*}{ Caulobacter segnis } & 4,76 & 1,5 & 0,03 & PHB & Flask & This study \\
\hline & 25 & 9,25 & 0,19 & PHB & Bioreactor & This study \\
\hline Haloferax mediterranei & 11 & 5,5 & 0,05 & PHB & Bioreactor & Koller et al. 2007 \\
\hline Halomonas halophila & 8,5 & 3,26 & 0,08 & PHB & Flask & Kucera et al. 2018 \\
\hline \multirow[t]{2}{*}{ Hydrogenophaga pseudoflava } & 2,03 & 0,6 & 0,01 & PHBV & Flask & Povolo et al. 2013 \\
\hline & 6,75 & 2,7 & 0,05 & PHBV & Bioreactor & Koller et al. 2007 \\
\hline \multirow[t]{2}{*}{ Methylobacterium sp. ZP24 } & 9,9 & 5,9 & 0,12 & PHB & Flask & Yellore \& Desai 1998 \\
\hline & -- & 3,9 & 0,06 & PHB & Bioreactor & Nath et al. 2008 \\
\hline \multirow[t]{3}{*}{ Pseudomonas hydrogenovora } & 10,8 & 1,3 & 0,03 & PHB & Bioreactor & Koller et al. 2007 \\
\hline & 11,7 & 1,44 & 0,05 & PHB & Bioreactor & Koller et al. 2008 \\
\hline & 10,6 & 1,27 & 0,04 & PHBV & Bioreactor & Koller et al. 2008 \\
\hline Thermus thermophilus HB8 & 1,43 & 0,5 & 0,01 & $\mathrm{PHA}^{*}$ & Flask & Pantazaki et al. 2009 \\
\hline
\end{tabular}

PHBV: poly(3-hydroxybutyrate-co-3-hydroxyvalerate) copolymer; *PHA: cointaining C5, C7, C9 and C11 hydroxyalcanoic acids.

While synthetic engineered strains are still being developed for industrial PHA production, a new wild type strain capable of producing PHA from lactose and whey has been identified by an in silico prospecting procedure and avoiding the use of genetic engineering techniques to obtain GMOs. As PHA has been successfully validated as in food packaging applications (Bucci et al., 2005), the transformation of whey into PHB is also a relevant example of circular economy for the food value chain. From a regulatory stand-point, whey may be considered a preferred raw material in relation to other industrial by-product streams in terms of food safety compliance, particularly to derive materials for food storage. This means a step forward for bioplastics production and progress in the development of safer and more efficient sustainable technologies. 


\subsection{Conclusions}

The purpose of this work was to find new bacteria capable of producing PHA from whey at good yields. In silico selection of strains and the Nile red method have demonstrated the ability of some biosafety level-1 bacteria to produce PHA from whey and permeate. Following a funnel strategy, starting from collection strains, the production process of PHA was optimized with strain C. segnis DSM 29236, which proved a good candidate for PHB production from whey. It is a gram-negative rod- or vibroid-shaped or fusiform bacterium, which has never been related to PHB production previously. The strain produced $1.5 \mathrm{~g} \mathrm{I}^{-1}$ of PHB $(31.5 \%$ of CDW) in discontinuous culture under optimized conditions found by modifying the amounts of nitrogen and carbon source of the culture media to achieve the appropriate production conditions. In addition, fed-batch fermentation assays have been carried out with $C$. segnis DSM 29236 reaching up to $9.25 \mathrm{~g} \mathrm{l}^{-1}$ of PHB with a 37\% accumulation of its CDW and with potential for improvement. This is the highest concentration reported to date, to our best knowledge, for a wild-type microorganism capable to directly hydrolyze and transform lactose from whey into PHB. Thus, this study is a promising step in the design of a sustainable and safe biotechnological process to produce biodegradable bioplastics using industrial waste as raw material and wild type strain as PHA producer.

\section{References}

Abraham, W.R., Strompl, C., Meyer, H., Lindholst, S., Moore, E.R., Christ, R. et al. (1999) Phylogeny and polyphasic taxonomy of Caulobacter species. Proposal of Maricaulis gen. nov. with Maricaulis maris (Poindexter) comb. nov. as the type species, and emended description of the genera Brevundimonas and Caulobacter. Int J Syst Bacteriol 49: 1053-1073.

Ahn, W.S., Park, S.J., and Lee, S.Y. (2000) Production of poly(3-hydroxybutyrate) by fed-batch culture of recombinant Escherichia coli with a highly concentrated whey solution. Appl Environ Microbiol 66: 36243627.

Anjum, A., Zuber, M., Zia, K.M., Noreen, A., Anjum, M.N., and Tabasum, S. (2016) Microbial production of polyhydroxyalkanoates (PHAs) and its copolymers: a review of recent advancements. Int $J$ Biol Macromol 89: 161-174. 
Baei, M.S., Najafpour, G., Lasemi, Z., Tabandeh, F., Younesi, H., Issazadeh, H., and Khodabandeh, M. (2010) Optimization PHAs production from dairy industry wastewater (cheese whey) by Azohydromonas lata DSMZ 1123. Iranica J Energy \& Environ 1: 132-136.

Berwig, K.H., Baldasso, C., and Dettmer, A. (2016) Production and characterization of poly (3hydroxybutyrate) generated by Alcaligenes latus using lactose and whey after acid protein precipitation process. Bioresour Technol 218: 31-37.

Borah, B., Thakur, P.S., and Nigam, J.N. (2002) The influence of nutritional and environmental conditions on the accumulation of poly- $\beta$-hydroxybutyrate in Bacillus mycoides RL B-017. J Appl Microbiol 92: 776783.

Bosco, F., and Chiampo, F. (2010) Production of polyhydroxyalcanoates (PHAs) using milk whey and dairy wastewater activated sludge: production of bioplastics using dairy residues. J Biosci Bioeng 109: 418-421.

Bozorg, A., Vossoughi, M., Kazemi, A., and Alemzadeh, I. (2015) Optimal medium composition to enhance Poly- $\beta$-hydroxybutyrate production by Ralstonia eutropha using cane molasses as sole carbon source. Appl Food Biotechnol 2: 39-47.

Braunegg, G., Bona, R., and Koller, M. (2004) Sustainable polymer production. Polym Plast Technol Eng 43: 1779-1793.

Brigham, C.J., and Sinskey, A.J. (2012) Applications of polyhydroxyalkanoates in the medical industry. Int J Biotechnol Wellness Ind 1: 52-60.

Buckley, R.M. (2013) The role of the phasin PhaP in promoting polyhydroxybutyrate (PHB) granule formation in Caulobacter crescentus [WWW document]. http://hdl.handle.net/1721.1/84372.

Bucci, D., Tavares, L., and Sell, I. (2005) PHB packaging for the storage of food products. Polym Test 24: 564-571.

Cases, I., and de Lorenzo, V. (2005) Genetically modified organisms for the environment: stories of success and failure and what we have learned from them. Int Microbiol 8: 213-222.

Castilho, L.R., Mitchell, D.A., and Freire, D.M. (2009) Production of polyhydroxyalkanoates (PHAs) from waste materials and by-products by submerged and solid-state fermentation. Bioresour Technol 100: 5996-6009.

Chanprateep, S. (2010) Current trends in biodegradable polyhydroxyalkanoates. J Biosci Bioeng 110: 621-632. 
Chen, G.Q. (2009) A microbial polyhydroxyalkanoates (PHA) based bio- and materials industry. Chem Soc Rev 38: 2434-2446.

Chen, G.Q., and Jiang, X. (2017) Engineering bacteria for enhanced polyhydroxyalkanoates (PHA) biosynthesis. Synth Syst Biotechnol 2: 192-197.

Chen, G.Q., Köning, K.H., Lafferty, R.M. (1991) Occurrence of poly-D(-)-3-hydroxyalkanoates in the genus Bacillus. FEMS Microbiol Lett 84: 173-176.

Chen, G.Q., and Wu, Q. (2005) Microbial production and applications of chiral hydroxyalkanoates. Appl Microbiol Biotechnol 67: 592-599.

Chertkov, O., Copeland, A., Lucas, S., Lapidus, A., Berry, K.W., Detter, J.C. et al. (2011) Complete genome sequence of Tolumonas auensis type strain (TA 4 T). Stand Genomic Sci 5: 112.

Cho, J.C., and Giovannoni, S.J. (2004) Oceanicola granulosus gen. nov., sp. nov. and Oceanicola batsensis sp. nov., poly- $\beta$-hydroxybutyrate-producing marine bacteria in the order 'Rhodobacterales'. Int J Syst Evol Microbiol 54: 1129-1136.

Coenye, T., Laevens, S., Willems, A., Ohlén, M., Hannant, W., Govan, J.R., Gillis, M., Falsen, E., Vandamme, P. (2001) Burkhloderia fungorum sp. nov. and Burkholderia caledonica sp. nov., two new species isolated from the environment, animals, and human clinical samples. Int J Syst Evol Microbiol 51: 1099-1107.

Cruz, M.V., Freitas, F., Paiva, A., Mano, F., Dionísio, M., Ramos, A.M., and Reis, M.A. (2016) Valorization of fatty acids-containing wastes and byproducts into short- and medium-chain length polyhydroxyalkanoates. New biotechnology 33: 206-215.

Curtis, P.D., and Brun, Y.V. (2010) Getting in the loop: regulation of development in Caulobacter crescentus. Microbiol Mol Biol Rev 74: 13-41.

Dietrich, K., Dumont, M., Del Rio, L.F., and Orsat, V. (2017) Producing PHAs in the bioeconomy-Towards a sustainable bioplastic. Sustainable Production and Consumption 9: 58-70.

Dinjaski, N., and Prieto, M.A. (2015) Smart polyhydroxyalkanoate nanobeads by protein based functionalization. Nanomedicine 11: 885-899.

de Eugenio, L.I., Escapa, I.F., Morales, V., Dinjaski, N., Galan, B., Garcia, J.L., and Prieto, M.A. (2010) The turnover of medium-chain-length polyhydroxyalkanoates in Pseudomonas putida KT2442 and the fundamental role of PhaZ depolymerase for the metabolic balance. Environ Microbiol 12: 207-221.

Farinha, I.d.S. (2009) Optimization of bioplastics production from cheese whey [WWW document]. http://hdl.handle.net/10362/2377 Accessed 10.10.2012. 
Fernández-Gutiérrez, D., Veillette, M., Giroir-Fendler, A., Ramirez, A.A., Faucheux, N., and Heitz, M. (2017) Biovalorization of saccharides derived from industrial wastes such as whey: a review. Rev Environ Sci Biotechnol 16: 147-174.

Gowda, V., and Shivakumar, S. (2014) Agrowaste-based polyhydroxyalkanoate (PHA) production using hydrolytic potential of Bacillus thuringiensis IAM 12077. Braz Arch Biol Technol 57: 55-61.

Jiang, G., Hill, D.J., Kowalczuk, M., Johnston, B., Adamus, G., Irorere, V., and Radecka, I. (2016) Carbon sources for polyhydroxyalkanoates and an Integrated biorefinery. Int J Mol Sci 17: 1157.

Jones, J.A., Toparlak, Ö.D., and Koffas, M.A. (2015) Metabolic pathway balancing and its role in the production of biofuels and chemicals. Curr Opin Biotechnol 33: 52-59.

Khanna, S., and Srivastava, A.K. (2005) Recent advances in microbial polyhydroxyalkanoates. Process Biochem 40: 607-619.

Khosravi-Darani, K., Vasheghani-Farahani, E., and Shojaosadati, S.A. (2004) Application of the Taguchi Design for Production of Poly( $\beta$-hydroxybutyrate) by Ralstonia eutropha. Iran J Chem \& Chem Eng 23: 131-136.

Koller, M. (2014) Poly (hydroxyalkanoates) for food packaging: application and attempts towards implementation. Appl Food Biotechnol 1: 3-15.

Koller, M. (2017) Production of Polyhydroxyalkanoate (PHA) Biopolyesters by Extremophiles. MOJ Polymer Science 1: 1-19.

Koller, M., Bona, R., Chiellini, E., Fernandes, E.G., Horvat, P., Kutschera, C. et al. (2008) Polyhydroxyalkanoate production from whey by Pseudomonas hydrogenovora. Bioresour Technol 99: 4854-4863.

Koller, M., Hesse, P., Bona, R., Kutschera, C., Atlic, A., and Braunegg, G. (2007) Potential of various archae- and eubacterial strains as industrial polyhydroxyalkanoate producers from whey. Macromol Biosci 7: 218-226.

Koller, M., Marsalek, L., de Sousa Dias, M.M., and Braunegg, G. (2017) Producing microbial polyhydroxyalkanoate (PHA) biopolyesters in a sustainable manner. New Biotechnol 37: 24-28.

Koller, M., Salerno, A., Muhr, A., Reiterer, A., Chiellini, E., Casella, S., Horvat, P. and Braunegg, G. (2012). Whey lactose as a raw material for microbial production of biodegradable polyesters. In Polyester. El-Din Saleh, H (ed). InTech. pp. 51-92. 
Koller, M., Sandholzer, D., Salerno, A., Braunegg, G., and Narodoslawsky, M. (2013) Biopolymer from industrial residues: life cycle assessment of poly (hydroxyalkanoates) from whey. Resour Conserv Recycling 73: 64-71.

Kshirsagar, P.R., Suttar, R., Nilegaonkar, S.S., Pradhan, S., and Kanekar, P.P. (2012) Scale up production of polyhydroxyalkanoate (PHA) at different aeration, agitation and controlled dissolved oxygen levels in fermenter using Halomonas campisalis MCM B-1027. J Biochem Tech 4: 512-517.

Kushmaro, A., Banin, E., Loya, Y., Stackebrandt, E., and Rosenberg, E. (2001) Vibrio shiloi sp. nov., the causative agent of bleaching of the coral Oculina patagonica. Int J Syst Evol Microbiol 51: 1383-1388.

Kucera, D., Pernicova, I., Kovalcik, A., Koller, M., Mullerova, L., Sedlacek, P. et al. (2018) Characterization of the promising poly(3-hydroxybutyrate) producing halophilic bacterium Halomonas halophila. Bioresour Technol. 256: 552-556.

Lageveen, R.G., Huisman, G.W., Preusting, H., Ketelaar, P., Eggink, G., and Witholt, B. (1988) Formation of polyesters by Pseudomonas oleovorans: effect of substrates on formation and composition of poly(R)-3-hydroxyalkanoates and poly-(R)-3-hydroxyalkenoates. Appl Environ Microbiol 54: 2924-2932.

Lauro, F.M., McDougald, D., Thomas, T., Williams, T.J., Egan, S., Rice, S. et al. (2009) The genomic basis of trophic strategy in marine bacteria. Proc Natl Acad Sci U S A 106: 15527-15533.

Lee, S.Y., Wong, H.H., Choi, J., Lee, S.H., Lee, S.C., and Han, C.S. (2000) Production of medium-chainlength polyhydroxyalkanoates by high-cell-density cultivation of Pseudomonas putida under phosphorus limitation. Biotechnol Bioeng 68: 466-470.

López Barragán, M.J., Carmona, M., Zamarro, M.T., Thiele, B., Boll, M., Fuchs, G. et al. (2004) The bzd gene cluster, coding for anaerobic benzoate catabolism, in Azoarcus sp. strain CIB. J Bacteriol 186: $5762-$ 5774.

Martinez, V., Garcia, P., Garcia, J.L., and Prieto, M.A. (2011) Controlled autolysis facilitates the polyhydroxyalkanoate recovery in Pseudomonas putida KT2440. Microb Biotechnol 4: 533-547.

Mollea, C., Bosco, F., and Marmo, L. (2013) Valorisation of cheese whey, a by-product from the dairy industry [WWW document]. http://dx.doi.org/10.5772/53159.

Mount, D.W. (2007) Using the Basic Local Alignment Search Tool (BLAST). CSH Protoc. http://dx.doi.org/10.1101/pdb.top17

Mozejko-Ciesielska, J., and Kiewisz, R. (2016) Bacterial polyhydroxyalkanoates: still fabulous? Microbiol Res 192: 271-282. 
Munk, A.C., Lapidus, A., Lucas, S., Nolan, M., Tice, H., Cheng, J. et al. (2011) Complete genome sequence of Tsukamurella paurometabola type strain (no. 33 T). Stand Genomic Sci 4: 342.

Nath, A., Dixit, M., Bandiya, A., Chavda, S., and Desai, A. (2008) Enhanced PHB production and scale up studies using cheese whey in fed batch culture of Methylobacterium sp. ZP24. Bioresour Technol 99: 5749-5755.

Narodoslawsky, M., Shazad, K., Kollmann, R., and Schnitzer, H. (2015) LCA of PHA production-identifying the ecological potential of bio-plastic. Chem Biochem Eng Q 29: 299-305.

Obruca, S., Marova, I., Melusova, S., and Mravcova, L. (2011) Production of polyhydroxyalkanoates from cheese whey employing Bacillus megaterium CCM 2037. Annals Microbiol 61: 947-953.

Obruca, S., Marova, I., Melusova, S., and Ondruska, V. (2009) Production of polyester-based bioplastics by Bacillus megaterium grown on waste cheese whey substrate under exogenous stress. New Biotechnol 25: S257.

Patel, S., Fletcher, B., Scott, D.C., and Ely, B. (2015) Genome sequence and phenotypic characterization of Caulobacter segnis. Curr Microbiol 70: 355-363.

Pais, J., Farinha, I., Freitas, F., Serafim, L.S., Martínez, V., Martínez, J.C. et al. (2014) Improvement on the yield of polyhydroxyalkanotes production from cheese whey by a recombinant Escherichia coli strain using the proton suicide methodology. Enzyme Microb Technol 55: 151-158.

Pais, J., Serafim, L.S., Freitas, F., and Reis, M.A. (2016) Conversion of cheese whey into poly (3hydroxybutyrate-co-3-hydroxyvalerate) by Haloferax mediterranei. N biotechnol 33: 224-230.

Pantazaki, A.A., Papaneophytou, C.P., Pritsa, A.G., Liakopoulou-Kyriakides, M., and Kyriakidis, D.A. (2009) Production of polyhydroxyalkanoates from whey by Thermus thermophilus HB8. Process Biochem 44: 847-853.

Pescuma, M., de Valdez, G.F., and Mozzi, F. (2015) Whey-derived valuable products obtained by microbial fermentation. Appl Microbiol Biotechnol 99: 6183-6196.

Pettinari, M.J., Vázquez, G.J., Silberschmidt, D., Rehm, B., Steinbüchel, A., Méndez B. (2001) Poly(3Hydroxybutyrate) synthesis genes in Azotobacter sp. strain FA8. Appl Envir Microbiol 67: 5331-5334.

Povolo, S., Casella, S. (2003) Bacterial production of PHA from lactose and cheese whey permeate. Macromol Symp 197: 1-9

Povolo, S., Romanelli, M.G., Basaglia, M., Ilieva, V.I., Corti, A., Morelli, A. et al. (2013) Polyhydroxyalkanoate biosynthesis by Hydrogenophaga pseudoflava DSM1034 from structurally unrelated carbon sources. N Biotechnol 30: 629-634. 
Prieto, A. (2016) To be, or not to be biodegradable... that is the question for the bio-based plastics. Microb Biotechnol 9: 652-657.

Prieto, M.A., de Eugenio, L.I., Galán, B., Luengo, J.M., and Witholt, B. (2007) Synthesis and degradation of polyhydroxyalkanoates. In Pseudomonas. Ramos, J.L., and Filloux, A. (eds), Netherlands: Springer, pp. 397-428.

Qi, Q., and Rehm, B.H. (2001) Polyhydroxybutyrate biosynthesis in Caulobacter crescentus: molecular characterization of the polyhydroxybutyrate synthase. Microbiology 147: 3353-3358.

Rao, R.S., Kumar, C.G., Prakasham, R.S., and Hobbs, P.J. (2008) The Taguchi methodology as a statistical tool for biotechnological applications: a critical appraisal. Biotechnol J 3: 510-523.

Raza, Z.A., Abid, S., and Banat, I.M. (2018) Polyhydroxyalkanoates: Characteristics, production, recent developments and applications. Int Biodeterior Biodegrad 126: 45-56.

Rehm, B.H.A. (2003) Polyester syntases: natural catalysts for plastics. Biochem J. 276: 15-33.

Reichelt, J.L., Baumann, P., and Baumann, L. (1976) Study of genetic relationships among marine species of the genera Beneckea and Photobacterium by means of in vitro DNA/DNA hybridization. Arch Microbiol 110: 101-120.

Rodriguez-Perez, S., Serrano, A., Pantión, A.A., and Alonso-Fariñas, B. (2018) Challenges of scaling-up PHA production from waste streams. A review. J Environ Manage 205: 215-230.

Ryan, M.P., and Walsh, G. (2016) The biotechnological potential of whey. Rev Environm Sci Biotechnol 15: $479-498$.

Sankar, P.L., and Cho, M.K. (2015) Engineering values into genetic engineering: A proposed analytic framework for scientific social responsibility. Am J Bioeth 15: 18-24.

Sathya, A.B., Sivasubramanian, V., Santhiagu, A., Sebastian, C., Sivashankar, R. (2018) Production of polyhydroxyalkanoates from renewable sources using bacteria. J Pol Environ 26: 3995-4012.

Skerman, V.B.D., McGowan, V., and Sneath, P.H.A. (1980) Approved lists of bacterial names. Int J Syst Evol Microbiol 30: 225-420.

Solaiman, D.K. (2000) PCR cloning of Pseudomonas resinovorans polyhydroxyalkanoate biosynthesis genes and expression in Escherichia coli. Biotechnol Lett 22: 789-794.

Spalatelu, C. (2012) Biotechnological valorisation of whey. Innov Rom Food Biotechnol 10: 1-8. 
Spiekermann, P., Rehm, B.H., Kalscheuer, R., Baumeister, D., and Steinbüchel, A. (1999) A sensitive, viable-colony staining method using Nile red for direct screening of bacteria that accumulate polyhydroxyalkanoic acids and other lipid storage compounds. Arch Microbiol 171: 73-80.

Srividya, S. (2011) Production of PHB from lactose and whey by Bacillus thuringiensis IAM 12077. Res J Biotech 6: 12-18.

Takeuchi, M., Hamana, K., and Hiraishi, A. (2001) Proposal of the genus Sphingomonas sensu stricto and three new genera, Sphingobium, Novosphingobium and Sphingopyxis, on the basis of phylogenetic and chemotaxonomic analyses. Int J Syst Evol Microbiol 51: 1405-1417.

Tan, D., Xue, Y.S., Aibaidula, G., and Chen, G.Q. (2011) Unsterile and continuous production of polyhydroxybutyrate by Halomonas TD01. Bioresour Technol 102: 8130-8136.

Tombolini, R., Povolo, S., Buson, A., Squartini, A., and Nuti, M.P. (1995) Poly- $\beta$-hydroxybutyrate (PHB) biosynthetic genes in Rhizobium meliloti 41. Microbiology 141 (Pt 10): 2553-2559.

Tsuge, T., Hyakutake, M., Mizuno, K. (2015). Class IV polyhydroxyalkanoate (PHA) synthases and PHAproducing Bacillus. Appl Microb Biotecnol 99: 6231-6240.

Urakami, T., Oyanagi, H., Araki, H., Suzuki, K., and Komagata, K. (1990) Recharacterization and emended description of the genus Mycoplana and description of two new species, Mycoplana ramosa and Mycoplana segnis. Int J Syst Evol Microbiol 40: 434-442.

Ushijima, B., Videau, P., Poscablo, D., Vine, V., Salcedo, M., Aeby, G., and Callahan, S. (2014) Complete genome sequence of Vibrio coralliilyticus strain OCN014, isolated from a diseased coral at Palmyra Atoll. Genome Announc 2: e01318-14.

Valappil, S.P., Boccaccini A.R., Bucke, C., Roy, I. (2007) Polyhydroxyalkanoates in Gram-positive bacteria: insights from the genera Bacillus and Streptomyces. Antonie van Leeuwenhoek 91: 1-17.

Velasco, D., Senit, J.J., de la Torre, I., Santos, T.M., Yustos, P., Santos, V.E., and Ladero, M. (2017) Optimization of the enzymatic saccharification process of milled orange wastes. Fermentation 3: 37.

Verlinden, R.A., Hill, D.J., Kenward, M.A., Williams, C.D., and Radecka, I. (2007) Bacterial synthesis of biodegradable polyhydroxyalkanoates. J Appl Microbiol 102: 1437-1449.

Verma, M., Kaur, J., Kumar, M., Kumari, K., Saxena, A., Anand, S. et al. (2011) Whole genome sequence of the rifamycin B-producing strain Amycolatopsis mediterranei S699. J Bacteriol 193: 5562-5563.

Walsh, C.J., Guinane, C.M., Hill, C., Ross, R.P., O’Toole, P.W., and Cotter, P.D. (2015) In silico identification of bacteriocin gene clusters in the gastrointestinal tract, based on the Human Microbiome Project's reference genome database. BMC microbiology 15: 183. 
Wang, Y., Yin, J., and Chen, G.Q. (2014) Polyhydroxyalkanoates, challenges and opportunities. Curr Opin Biotechnol 30: 59-65.

Wojtusik, M., Rodríguez, A., Ripoll, V., Santos, V.E., García, J.L., and García-Ochoa, F. (2015) 1,3Propanediol production by Klebsiella oxytoca NRRL-B199 from glycerol. Medium composition and operational conditions. Biotechnol Rep 6: 100-107.

Yang, Y., pen Yeh, L., Cao, Y., Baumann, L., Baumann, P., Tang, J.S., and Beaman, B. (1983) Characterization of marine luminous bacteria isolated off the Coast of China and description of Vibrio orientalis sp. nov. Curr Microbiol 8: 95-100.

Yang, Y., Brigham, C.J., Budde, C.F., Boccazzi, P., Willis, L.B., Hassan, M.A. et al. (2010) Optimization of growth media components for polyhydroxyalkanoate (PHA) production from organic acids by Ralstonia eutropha. Appl Microbiol Biotechnol 87: 2037-2045.

Yellore, V., and Desai, A. (1998) Production of poly-3-hydroxybutyrate from lactose and whey by Methylobacterium sp. ZP24. Lett Appl Microbiol 26: 391-394.

Young, F.K., Kastner, J.R., and May, S.W. (1994) Microbial production of poly- $\beta$-hydroxybutyric acid from D-xylose and lactose by Pseudomonas cepacia. Appl Environ Microbiol 60: 4195-4198.

Zarins-Tutt, J.S., Barberi, T.T., Gao, H., Mearns-Spragg, A., Zhang, L., Newman, D.J., and Goss, R.J.M. (2016) Prospecting for new bacterial metabolites: a glossary of approaches for inducing, activating and upregulating the biosynthesis of bacterial cryptic or silent natural products. Nat Prod Rep 33: 54-72.

Zwick, M.E., Joseph, S.J., Didelot, X., Chen, P.E., Bishop-Lilly, K.A., Stewart, A.C. et al. (2012) Genomic characterization of the Bacillus cereus sensu lato species: backdrop to the evolution of Bacillus anthracis. Genome Res 22: 1512-1524. 


\section{CHAPTER II}

Camelina oil as a promising substrate for mcl-PHA production in Pseudomonas sp. cultures

Adapted from: Applied Food Biotechnology 2019, 6(1), 61-70

https://doi.org/10.22037/afb.v6i1.21635 


\subsection{Background and aim}

Food surplus and byproducts frequently produced by agriculture and other industries can be exploited as low-cost substrates in biotechnological processes as a driver for biobased and circular economy strategies. The production of bacterial polyesters by fermentation from such substrates, specifically the production of polyhydroxyalkanoates (PHAs), could be one of the possible applications of this concept. The synthesis and use of biodegradable plastics is a promising alternative to replace the use of petroleum derivatives and research in the generation of bioplastics such as PHAs is an effective solution towards sustainable development (Braunegg et al., 2004; Koller et al., 2017).

PHAs are biodegradable and biocompatible polyesters that are accumulated as intracellular carbon and energy reserves in many prokaryotic organisms. Different types of polymers can be produced depending on the selected bacterial species and on the carbon source used during fermentation process: short-chain length PHA (scl-PHA), with monomers 4 to 5 carbon atoms are often stiff and brittle and medium-chain length PHA ( $m c l-P H A)$, with monomers from 6 to 16 carbon atoms are elastomeric in nature. PHAs are thermoplastic polymers with similar behavior to polyolefins, but with the advantage of being from renewable origin, biodegradable and biocompatible, therefore they can be used in a wide range of application from medicine to food packaging, however their price is still higher than their conventional counterparts (Prieto, 2007; Chen, 2009; Chanprateep, 2010 Brigham and Sinskey, 2012; Koller, 2014; KhosraviDarani and Bucci, 2015). PHA-storing microorganisms commonly produce PHA from simple carbon sources, such as sugars, but fatty acids have traditionally been the preferred substrates for studies investigating the production of $\mathrm{mcl}$-PHA for their comparably higher transformation yields due to the metabolic pathway of fatty acids degradation (" $\beta$-oxidation"), that provides the structurally related precursors for PHA production. Other organisms than Pseudomonades produce scl-PHA when supplied with oils (Koller and Braunegg, 2015; Rodrigues and Druzian, 2018). However, the high price of those feedstocks accounts for up to $50 \%$ of the overall PHA production costs. In addition, most of the PHA-accumulating bacterial strains are not capable to convert triglycerides into fatty acids, then prior hydrolysis to yield free fatty acids or saponification is required, which increase the overall production costs (Walsh et al., 2015; Cruz et al., 2016). Transesterification to (methyl)esters is a third possibility to convert triacylglycerides to low molecular mass units to be converted by microbes, but the strategies for reducing the costs of PHA production are focused on reducing raw material pretreatment stages as well as optimizing PHA recovery and purification; or even using some C1 carbon 
sources, e.g., methane, methanol, and $\mathrm{CO}_{2}$ are cheap substrates and have received attention due to their serious role in greenhouse problem (Koller and Braunegg, 2015; Muhr et al., 2013ab; Khosravi-Darani et al., 2013).

Plant oil as raw material for PHA production is interesting due to its relative low cost and the minimal processing required compared to fatty acids. As the demand for vegetable oils for food has increased dramatically in recent years, it is not realistic to justify the use of these oils in other purposes such as fuel or bioplastics production (Carlsson, 2009). Non-edible vegetable oils can be considered as promising substitutions for traditional edible food crops and in this context Camelina (C.) sativa can be a sustainable plant for biofuel and biomaterial sustainable production (Chhetri et al., 2008; Atabani et al., 2013).

C. sativa is a member of the Brassicaceae family and is adaptable to many different environmental conditions. The use as food is partly limited due to Camelina's smaller oil yields per hectare, as well as its strong taste and smell caused by components that are difficult to remove from the oil (Berti et al., 2016; Zanetti et al., 2017). Camelina is an ideal crop for use on less productive lands due to the relatively low inputs required for its cultivation. Therefore, Camelina crops could be a good candidate to produce biofuels or biopolymers without displacing crops used for food production (Sainger et al., 2017). Poly(3-hydroxybutyrate) (PHB) production in plastids of transformed $C$. sativa seeds was investigated before, but products of this plant have never been tested for PHA production by microorganisms, particularly $\mathrm{mcl}$-PHA with Pseudomonas strains (Malik et al., 2015).

Mcl-PHA is accumulated by some Pseudomonas species from different oily substrates but some of them are opportunistic pathogens unsuitable for PHA production at an industrial level (Marsudi et al., 2008; Impallomeni et al., 2011). Some of these studies compared the growth on oils to the growth on individual pure fatty acids, mainly oleic acid. Genetic engineering has also been used to express lipase genes in well-known PHA-producing strains, such as P. putida, P. oleovorans and P. corrugata to allow them to grow directly on oils (Solaiman et al., 2001; Solaiman et al., 2002). Recent studies show the ability of some strains to grow to high cell density when they are cultivated on plant oils and compare their performance using plant oils with crude fatty acid mixtures generated from the hydrolysis of oils (Walsh et al., 2015).

The objective of this work is to validate the use of Camelina oil for the production of $\mathrm{mcl}$-PHA by Pseudomonas strains, exploiting its potential as a renewable, non-food competing, lipid rich substrate. 


\subsection{Materials and Methods}

\subsubsection{Bacterial strains, media and growth conditions}

The bacterial strains employed in this study are P. putida KT2442 (a rifampycin sensitive mutant from KT2440 strain), $P$. oleovorans GPo1 and $P$. resinovorans DSM 21078. Cells were initially cultured in an undefined rich medium (Luria-Bertani, LB) and stored in $20 \%$ glycerol for long-term preservation. Solid media were supplemented with $1.5 \%\left(w^{-1}\right)$ agar. Seed cultures were prepared in flasks containing LB medium by incubating in a rotary shaker overnight at $30^{\circ} \mathrm{C}$ and $180 \mathrm{rpm}$.

The production of PHA was evaluated in flaks cultures with $0.1 \mathrm{~N} \mathrm{M63,} \mathrm{which} \mathrm{is} \mathrm{a} \mathrm{nitrogen-}$ limited minimal medium (Moldes et al., 2004), supplemented with crude Camelina oil at $15 \mathrm{~g} \mathrm{I}^{-}$ ${ }^{1}$ or saponified oil to compare the production capability of the strains. Mineral Modified-R medium described by Lee and colleagues (Lee et al., 2000) with the initial $\mathrm{KH}_{2} \mathrm{PO}_{4}$ concentration set at $4 \mathrm{~g} \mathrm{l}^{-1}$ was used to optimize PHA production in flasks cultures. The $\mathrm{pH}$ value was set to 7 in all cases and Camelina oil was added at different concentrations ranging from 2.5 to $10 \mathrm{~g} \mathrm{I}^{-1}$ to the cultures after 20 hours. Bacteria were incubated in flasks with stirring, at $30^{\circ} \mathrm{C}$ and $180 \mathrm{rpm}$ during 48 hours. Growth was measured by absorbance at $600 \mathrm{~nm}$ in a Biochrome libra $\mathrm{S} 60$ spectrophotometer.

\subsubsection{Bioreactor assays}

Fermentation was performed in the 1.5-L Applikon ${ }^{\circledR}$ reactor with a working volume of 0.5 liter at $30^{\circ} \mathrm{C}$. $\mathrm{pH}$ was controlled at 7.0 by the addition of $12.5 \%\left(\mathrm{v} \mathrm{v}^{-1}\right)$ ammonia also provided as a nitrogen source. The oxygen saturation was controlled at $20 \%$ by controlling the agitation speed between 300 and $1000 \mathrm{rpm}$ with up to $1 \mathrm{v} v \mathrm{~m}$ of air flow rate. Foaming was controlled by adding Antifoam 204 (Sigma-Aldrich) when necessary. Fermentation were carried out with P. resinovorans DSM 21078 in Modified- $\mathrm{R}$ medium with the initial $\mathrm{KH}_{2} \mathrm{PO}_{4}$ concentration set at $4 \mathrm{~g} \mathrm{I}^{-1}$ and $\left(\mathrm{NH}_{4}\right) \mathrm{HPO}_{4}$ at $1 \mathrm{~g} \mathrm{I}^{-}($Ahn et al., 2000; Lee et al., 2000). Initial oil concentration was 10 $\mathrm{g} \mathrm{I}^{-1}$, and several pulses were added up to total oil concentration of $60 \mathrm{~g} \mathrm{I}^{-1}$ to prevent starvation of the bacteria and therefore polymer degradation; a first addition of $10 \mathrm{~g} \mathrm{l}^{-1}$ of oil was added at 10 hours after the beginning of the assay; another pulse of $10 \mathrm{gl}^{-1}$ was added at 20 hours, and a final pulse of $30 \mathrm{~g} \mathrm{l}^{-1}$ was added at 32 hours. The addition of the pulses was performed at the moment the oxygen saturation started to increase above $20 \%$. 


\subsubsection{Analytical procedures}

PHA was determined by acidic methanolysis and gas chromatography of lyophilized culture samples. For this purpose, after 48 hours incubation, biomass was collected from $50 \mathrm{ml}$ broth samples by centrifugation ( $3000 \times$ g, 20 min., Eppendorf 5810R Centrifuge) and lyophilized. Methanolysis reaction was performed weighing 5-7 mg of dry cells (assuming that at least 10\% ( $w w^{-1}$ ) of PHA accumulation is achieved), using $2 \mathrm{ml}$ of $\mathrm{H}_{2} \mathrm{SO}_{4}$ in $15 \%\left(\mathrm{v} \mathrm{v}^{-1}\right)$ in methanol and 2 $\mathrm{ml}$ chloroform, and incubating for 4 hours at $100^{\circ} \mathrm{C}$ to transform the PHA into hydroxymethyl esters. Methyl benzoate was used as an internal standard. The resulting methyl esters were collected in the chloroform phase and analyzed by gas chromatography (Lageveen et al., 1988). PHA produced by $P$. putida KT2442 from different fatty acids or glucose were used as bioplastic standards. The equipment used was an Agilent $6890 \mathrm{~N}$ gas chromatograph with flame ionization detector and HP5-MS column.

Fatty acid profiles of Camelina oil were obtained by gas chromatography of the fatty acid methyl ester derivatives with the method mentioned above but individual peaks were identified by referring to a fatty acids methyl esters standard solution, analyzed under the same operation conditions.

\subsubsection{Camelina oil treatments}

In order to test the potential of the Camelina oil as a substrate for the production of PHA a fraction of oil was saponified. A sample of $10 \mathrm{~g}$ of Camelina oil was added to the ethanolic potassium hydroxide solution prepared by dissolving $3 \mathrm{~g}$ potassium hydroxide in $100 \mathrm{~mL}$ ethanol. The mixture was refluxed gently for $60 \mathrm{~min}$. The ethanol was then removed by rotary evaporation under reduced pressure, leaving behind solid potassium salts of fatty acids (Tan et al., 1997). On the other hand, two lipases were added to cultures of $P$. putida KT2442 to compare the accumulation of PHA versus the accumulation of $P$. resinovorans DSM 21078 from crude Camelina oil: Lipase A "Amano" 12 (Amano Enzyme U.S.A.) and Lipase CALB-L (Novozymes) at $1.0 \mathrm{gl}^{-1}$ and $3 \mathrm{ml}$ per liter respectively.

\subsubsection{Polymer recovery and characterization}

Cells were harvested from bioreactor cultures by centrifugation $(3000 \times g, 20$ min., Eppendorf $5810 R$ Centrifuge) and then lyophilized. The lyophilized cells were mixed with chloroform ( $25 \mathrm{~g}$ $\mathrm{I}^{-1}$ ) and kept at $30^{\circ} \mathrm{C}$, during $24 \mathrm{~h}$, with constant stirring. The mixture was allowed to decant, 
and the supernatant was filtered using a $0.2 \mu \mathrm{m}$ PTFE filter and concentrated by rotary evaporation under vacuum. The polymer was precipitated using $10 \mathrm{vol}$. of cold methanol and the supernatant was decanted. PHA was resuspended in a minimum amount of acetone and allowed to dry before further analysis.

The average molecular mass $\left(M_{w}\right)$, the molecular number $\left(M_{n}\right)$, and the polydispersity index of the polymer were measured by Gel permeation chromatography using a pre-column PSS GRAM $10 \mu \mathrm{m}, 30$ Å; ID $8.0 \mathrm{~mm} \times 50 \mathrm{~mm}$ and a column PSS GRAM $10 \mu \mathrm{m} ; 30,100,3000 \AA ̊$; ID $8.0 \mathrm{~mm} \times 50 \mathrm{~mm}$ with a PSS SECcurity 1260 Differencial Refractometer RID. DMF with $0.01 \mathrm{M}$ $\mathrm{LiBr}$ was used as the eluent at flow rate of $1.0 \mathrm{ml} \mathrm{min}^{-1}$ at $70^{\circ} \mathrm{C}$. Monodisperse polystyrene was used as standard material. Sample concentration of $0.5 \%\left(w^{-1}\right)$ and injection volumes of $50 \mu \mathrm{l}$ were used.

\subsection{Results and Discussion}

\subsubsection{Characterization of Camelina oil and its use for PHA production by Pseudomonas $s p$.}

Fatty acid composition of Camelina oil was determined (Table 1). The determination of the composition of the oil was carried out by comparison with standards of main fatty acids according to literature (Moser, 2010). The principal fatty acids found in Camelina oil were eicosenoic, linoleic, linolenic, and oleic. This crop presents variability in its composition attributable to factors such as climate and particular conditions at growing location (Zanetti et al., 2017).

Table 1. Fatty acid composition of Camelina oil used in this work (triplicate results).

\begin{tabular}{lll}
\hline Fatty acid & Carbon Number & $\left(\% \mathbf{w ~ w ~ w}^{-1}\right)$ \\
\hline Stearic & (C18:0) & $2.5 \pm 0.3$ \\
Eicosenoic & (C20:1) & $16.7 \pm 0.5$ \\
Linoleic & (C18:2) & $18.4 \pm 0.7$ \\
Linolenic & (C18:3) & $36.3 \pm 2.1$ \\
Oleic & (C18:1) & $15.1 \pm 1.5$ \\
Palmitic & (C16:0) & $5.6 \pm 0.2$ \\
Erucic & (C22:1) & $2.8 \pm 0.1$ \\
Others & - & 5.1 \\
\hline
\end{tabular}


A nitrogen-limited culture medium (0.1 N M63) was chosen to compare the accumulation of PHA with the selected strains: P. putida KT2442, P. oleovorans GPo1 [nowadays called $P$. putida GPo1 (Hartmann et al., 2006)] and P. resinovorans DSM 21078. These strains can accumulate considerable amounts of $\mathrm{mcl}$-PHA with excess carbon source and nitrogen source limitation, therefore the $0.1 \mathrm{~N} \mathrm{M63}$ culture medium is the most suitable for this purpose. On the other hand, few strains of the Pseudomonas genus have the ability to assimilate the triglycerides of the oil directly. Therefore, a sample of oil has been saponified to compare the accumulation of PHA with crude oil and with saponified oil (Figure 1). The strains P. putida KT2442 and P. oleovorans GPo1 showed accumulation of PHA only when saponified oil was added to the culture medium unlike the strain P. resinovorans DSM 21078 which produced PHA with both substrates. This strain has lipases that can hydrolyse the triglycerides of the oil and assimilate the free fatty acids to accumulate PHA (Ramsay et al., 1192; Ashby and Foglia, 1998). These results showed that Camelina oil is a very suitable candidate as a substrate for the production of $m c /$-PHA with P. resinovorans without any pre-treatment.

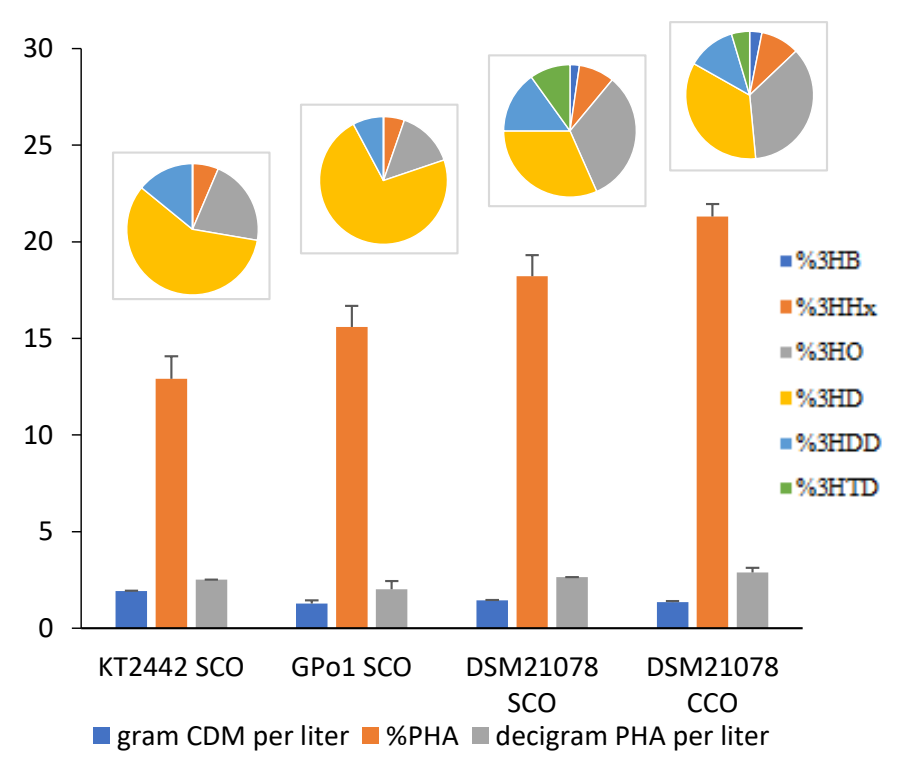

Figure 1. Production of $m c /$-PHA by $P$. putida KT2442, $P$. oleovorans GPo1 and P. resinovorans DSM 21078 using $0.1 \mathrm{~N} \mathrm{M} 63$ culture medium with $15 \mathrm{~g} \mathrm{~L}^{-1}$ of crude Camelina oil (CCO) or $15 \mathrm{~g} \mathrm{I}^{-1}$ of saponified oil (SCO). 3HB: 3-hydroxybutiric acid, 3HHx: 3-hydrodxyhexanoic acid, 3HO: 3-hydroxyoctanoic acid, 3HD: 3-hydroxydecanoic acid, 3HDD: 3-hydroxydodecanoic acid, 3HTD: 3-hydroxytetradecanoic acid

In addition, phosphorous limitation conditions were also evaluated. This feeding strategy has been previously reported to deliver high PHA concentrations with P. putida KT2440 using oleic acid as a carbon source in high-cell density cultures (Lee et al., 2000). These culture conditions 
were tested with strain P. resinovorans DSM 21078 using R-modified medium and adding $15 \mathrm{~g}$ $\mathrm{I}^{-1}$ of crude oil. Pseudomonas putida KT2442 is a model bacteria used commonly for mcl-PHAs production (De Eugenio et al., 2010), therefore in parallel the same test was carried out with this strain but adding two different lipases, Lipase A and CALB-L, directly to the culture as previously explained (see Materials and Methods section). Results are shown in Figure 2. The $P$. resinovorans strain grew better than the $P$. putida strain and produces a considerable amount of PHA from crude Camelina oil (28.8\% of CDM and $3.8 \mathrm{~g}$ PHA per liter), therefore, this culture medium was selected to initiate trials of fed-batch cultures with $P$. resinovorans DSM 21078.

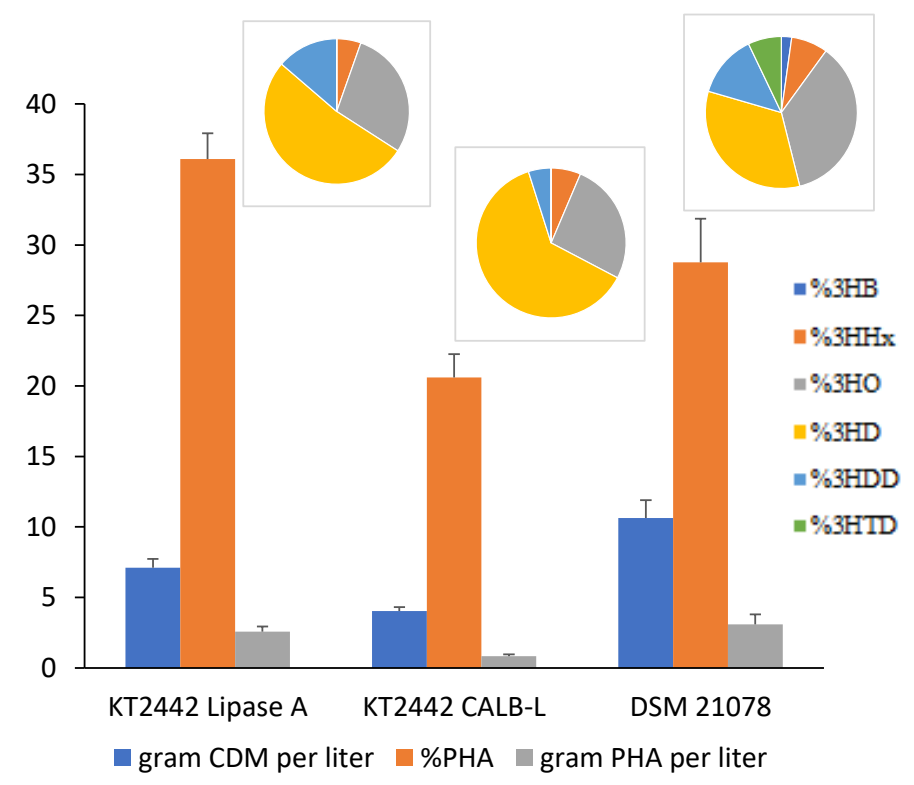

Figure 2. Production of $\mathrm{mcl}$-PHA with R-Modified culture medium and $15 \mathrm{~g} \mathrm{~L}^{-1}$ of Camelina oil. 3HB: 3hydroxybutyric acid, 3HHx: 3-hydrodxyhexanoic acid, 3HO: 3-hydroxyoctanoic acid, 3HD: 3hydroxydecanoic acid, 3HDD: 3-hydroxydodecanoic acid, 3HTD: 3-hydroxytetradecanoic acid

\subsubsection{Production of PHA in fed-batch cultures with P. resinovorans DSM 21078.}

Fed-batch cultures have been performed to find the optimal growing conditions and regulate the production of mcl-PHA. Cultures of $P$. resinovorans DSM 21078 were prepared in Rmodified medium with different initial quantities of crude Camelina oil: 2.5, 5 and $10 \mathrm{~g} \mathrm{I}^{-1}$ and with a substrate addition at 20 hours of $10 \mathrm{~g} \mathrm{I}^{-1}$ of Camelina oil (Figure 3, A-D) when the cells have consumed part of the initial substrate. These flask cultures were incubated at $30^{\circ} \mathrm{C}$ and $180 \mathrm{rpm}$ for 48 hours and samples were taken at 20 and 48 hours of fermentation. Figure 3 shows the results obtained. While for an initial substrate concentration of $2.5 \mathrm{~g} \mathrm{I}^{-1}$ and at 20 
hours of culture the growth of the strain is low with an accumulation of PHA around $4 \%$, a significant increase in the growth of the strain with an accumulation of $17.5 \%$ was observed when the substrate concentration was $5 \mathrm{~g} \mathrm{l}^{-1}$ at the beginning of the fermentation. The best result in the accumulation of $\mathrm{mcl}-\mathrm{PHA}$ was obtained with $10 \mathrm{gl}^{-1}$ of substrate at the beginning of the fermentation (44\% of CDM and $4.2 \mathrm{~g} \mathrm{PHA}$ per liter), although it is similar to that obtained in the previous case with $5 \mathrm{gl}^{-1}$ of substrate at the end of the assay (41\% of DCM and $3.9 \mathrm{~g}$ PHA per liter). Therefore, R-modified medium is a suitable medium for the fed-batch production of $\mathrm{mcl}$-PHA with an initial concentration of $10 \mathrm{~g} \mathrm{I}^{-1}$ to avoid substrate depletion on batch stage taking into account that growing conditions are better in bioreactor cultivations. Figure 3D shows the monomeric composition of the biopolymer obtained in each case where the proportion of the monomers was similar in all cases with variations in C8, C10 and C14 monomers.
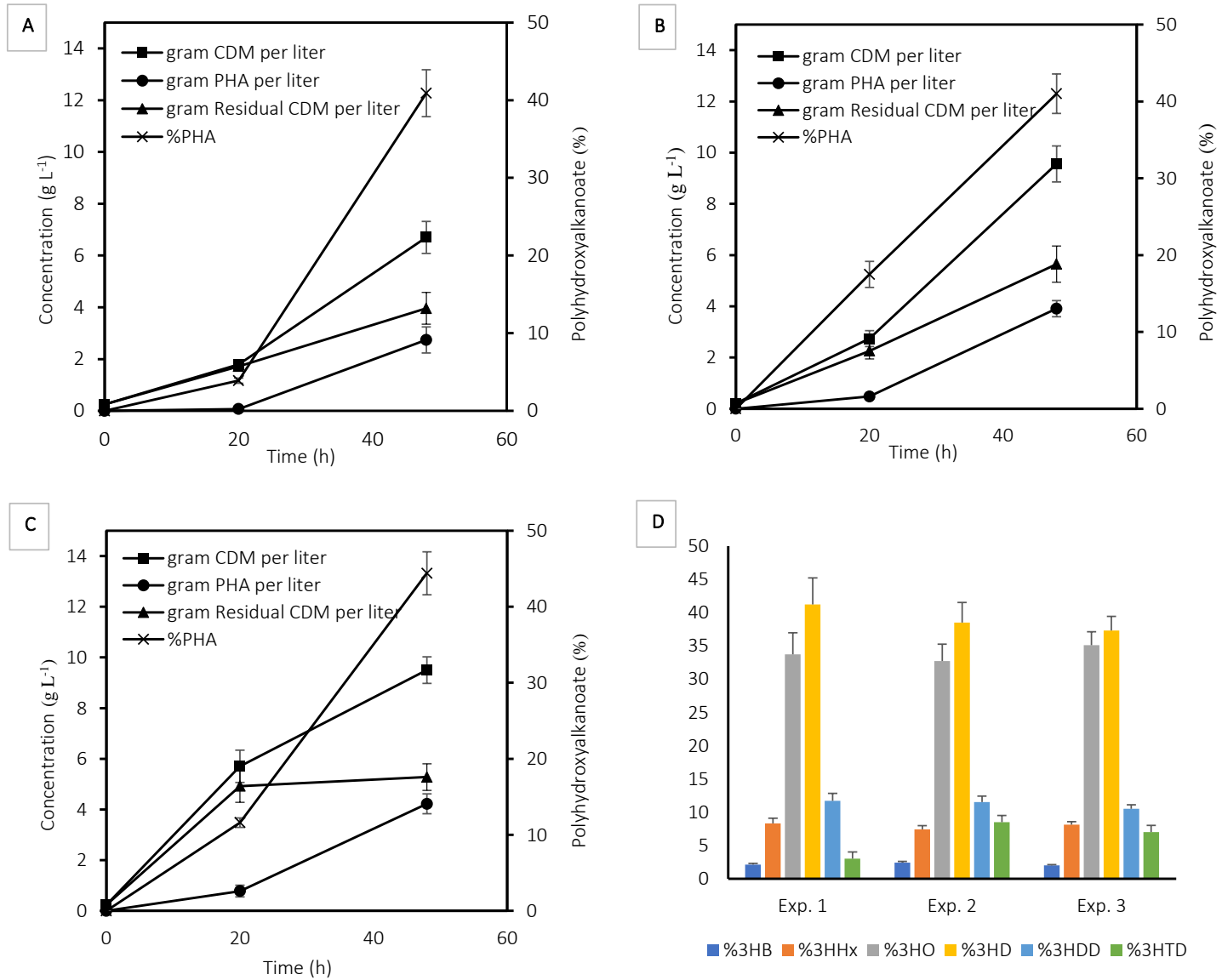

Figure 3. Shake flasks production of mcl-PHA by Pseudomonas resinovorans DSM 21078 using different initial concentration of Camelina oil. A pulse of $10 \mathrm{~g} \mathrm{I}^{-1}$ of substrate at 20 hours was made. A. $2.5 \mathrm{~g} \mathrm{I}^{-1}$. B. $5 \mathrm{~g} \mathrm{I}^{-1}$. C. $10 \mathrm{~g} \mathrm{I}^{-1}$. D. Composition of polymers obtained at the end of each assay. 3HB: 3-hydroxybutyric acid, 3HHx: 3-hydrodxyhexanoic acid, 3HO: 3-hydroxyoctanoic acid, 3HD: 3-hydroxydecanoic acid, 3HDD: 3-hydroxydodecanoic acid, 3HTD: 3-hydroxytetradecanoic acid 
Biorreactor assays were used to evaluate the behavior of the selected strain during PHA production and to optimize the fermentation to achieve high cell density cultures. As mentioned before, PHA is an intracellular product, so it is very important to obtain high cell density cultures as a step prior to the industrial scale-up (Rodriguez-Perez et al., 2018). Fermentation was performed using the R-modified medium with less quantity of nitrogen source (at $1 \mathrm{~g} \mathrm{I}^{-1}$ of $\left(\mathrm{NH}_{4}\right)_{2} \mathrm{HPO}_{4}$ ) to ensure that growth is regulated by the demand for ammonia during fermentation and to induce PHA accumulation by phosphate limitation. The ammonia solution for $\mathrm{pH}$ correction was not replaced by $\mathrm{NaOH}$ solution after the growth phase. The experiment was carried out in fed-batch because in batch mode the whole crude oil tended to emulsify the culture medium. The protocol was elaborated observing its behaviour during the test and adding the oil pulses when the saturation of oxygen started to increase above $20 \%$, as explained in Materials and Methods section. The results of the experiment are shown in Figure 4. Fermentation was finished after 45 hours; and under these conditions the strain achieved an accumulation of $m c /$-PHA of $35.6 \%$ of its cell dry mass, $13.5 \mathrm{~g} \mathrm{I}^{-1}$ of PHA was obtained. The production of PHA obtained with this experiment is about three to four times higher than the value obtained in flask and matches the highest titer of $\mathrm{mcl}$-PHA (13.2 $\mathrm{g} \mathrm{I}^{-1}$ ) obtained in bioreactor cultivations with $P$. clororaphis using plant derived oils as a substrate (Table 2). Mcl-PHA content (around 40\%) is within the range of PHA accumulation found with pure fatty acid substrates, a relevant requirement for efficient downstream recovery. It is also worth noting that $\mathrm{mcl}$-PHA is produced directly from the substrate without previous hydrolysis or further conditioning, highlighting the potential of the combination of Camelina oil and $P$. resinovorans for efficient $m c /$-PHA production.

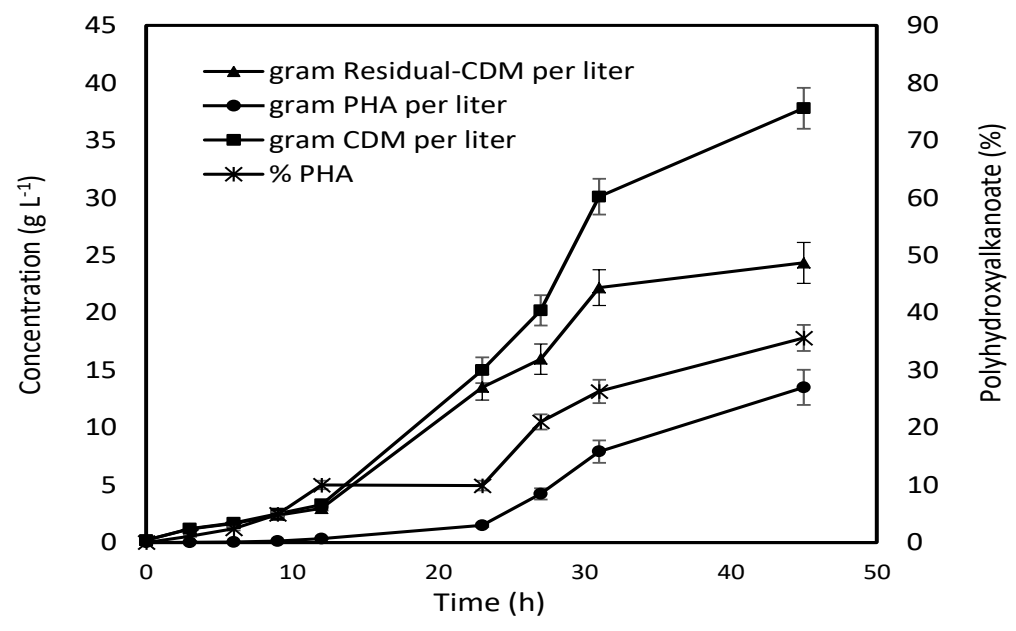

Figure 4. Growth and mcl-PHA production by Pseudomonas resinovoras DSM 21078 for the fed-batch fermentation with additions of Camelina oil 
Table 2. Production of Medium-chain-length Polyhydroxyalkanoates from vegetable oils in shaking flask and bioreactor by Pseudomonas sp. strains: overview of literature data.

\begin{tabular}{|c|c|c|c|c|c|}
\hline Microorganism & Plant oil & Device & $\begin{array}{l}\text { CDM } \\
\left(\mathrm{g} \mathrm{I}^{-1}\right)\end{array}$ & \%PHA & Reference \\
\hline \multirow[t]{2}{*}{ P. aeroginosa } & Palm oil & Biorreactor & 2.7 & 39 & Marsudi et al. (2018) \\
\hline & Brassica carinata oil & Flask & 1.0 & 5 & $\begin{array}{l}\text { Impallomeni et al. } \\
\text { (2011) }\end{array}$ \\
\hline \multirow[t]{3}{*}{ P.chlororaphis } & Different plant oils & Flask & $0.7-0.9$ & $27-34$ & Walsh et al. (2015) \\
\hline & Rapeseed oil & Biorreactor & 51 & 26 & Walsh et al. (2015) \\
\hline & Palm kernel oil & Biorreactor & 3.3 & 45 & Yun et al. (2003) \\
\hline P. putida & Different plant oils & Flask & $0.3-0.5$ & $11-25$ & Walsh et al. (2015) \\
\hline \multirow[t]{3}{*}{ P. resinovorans } & Different plant oils & Flask & $2.9-3.8$ & $40-51$ & Ramsay et al. (1992) \\
\hline & Camelina sativa oil & Flask & 10.6 & 28.7 & This study \\
\hline & Camelina sativa oil & Biorreactor & 37.9 & 35.6 & This study \\
\hline P. saccharophila & Soybean, sunfluwer oils & Flask & - & - & Solaiman et al. (1999) \\
\hline Pseudomonas sp. & Corn oil & Flask & 0.96 & 37.3 & Song et al. (2008) \\
\hline
\end{tabular}

$P=$ Pseudomonas

\subsubsection{Recovery and characterization of PHA produced by P. resinovorans DSM 21078.}

After fermentation, the PHA produced was recovered from freeze-dried cell powder in chloroform. The recovery rate was $92 \%$, and then the polymer was precipitated three times in cold methanol to increase its purity (see materials and methods section) and recovered as a film. The monomer composition of the PHA produced by P. resinovorans DSM 21078 was analyzed by GC-FID (Table 3) and compared to reference composition reported in previous studies. The monomer composition was: $2 \%$ 3-hydroxybutyrate (3HB), $7.5 \% \quad 3$ hydroxyhexanoate $(3 \mathrm{HHx}), 38 \%$ 3-hydroxyoctanoate (3HO), 37\% 3-hydroxydecanoate (3HD), 13\% 3-hydroxydodecanoate (3HDD) and 2.5\% 3-hydroxytetradecanoate (3HTD), similar to any other mcl-PHA composition produced by other Pseudomonas strains using vegetable oils (Walsh et al., 2015). Previous studies suggest that polymer composition can be manipulated on the basis of the substrate used (Ashby and Foglia, 1998) which is interesting to modify the characteristics and properties of the polymer if necessary. Finally, the biopolymer has a $M_{n}$ of $52.4 \mathrm{kDa}$ and $M_{w}$ of $131 \mathrm{kDa}$ with a PDI of 2.5, analyzed by GPC. Molecular weights of PHA depend on the substrate and the strain PHA synthase (Chen, 2009). Reported Mn and PDI values for PHA produced with $P$. resinovorans from vegetable oils rank from 65 to $100.1 \mathrm{KDa}$, and 1.65-1.81, respectively (Ashby and Foglia, 1998). It is not possible to compare with other 
publications regarding Camelina oil, as this is the first example of the use of this vegetable oil. Camelina oil contains high fractions of unsaturated fatty acids according to the composition of the oil presented above and Pseudomonades form unsaturated mcl-PHA building blocks to a certain extend by the use of these substrates due to $\beta$-oxidation pathway. Therefore, follow-up studies will encompass the more in-depth investigation of the monomeric composition of the polymer.

Table 3. Molar composition of the Medium-chain-length Polyhydroxyalkanoates produced by Pseudomonas resinovorans DSM 21078 using Camelina oil (duplicate results) compared with polymers produced by Pseudomonas resinovorans NRRL B-2649 with different vegetable oils (Ashby and Foglia, 1998).

\begin{tabular}{|c|c|c|c|c|c|c|c|c|c|}
\hline \multirow{2}{*}{ Strain } & \multicolumn{6}{|c|}{$\%$ Monomers $\left(w w^{-1}\right)$} & \multirow{2}{*}{$\begin{array}{l}M_{n} \\
(\mathrm{kDa})\end{array}$} & \multirow{2}{*}{$\begin{array}{l}M_{w} \\
(\mathrm{kDa})\end{array}$} & \multirow{2}{*}{ PDI } \\
\hline & $3 \mathrm{HB}$ & $3 \mathrm{HHx}$ & $3 \mathrm{HO}$ & $3 H D$ & 3HDD & 3HTD & & & \\
\hline $\begin{array}{l}\text { P. resinovoras } \\
\text { DSM } 21078\end{array}$ & $2 \pm 0.5$ & $7.5 \pm 1.0$ & $38 \pm 2$ & $37 \pm 3$ & $13 \pm 1$ & $2.5 \pm 0.7$ & $0.5 \pm 0.2$ & $1.3 \pm 0.5$ & 2.5 \\
\hline $\begin{array}{l}\text { P. resinovoras } \\
\text { NRRL B-2649 }\end{array}$ & $<1-1$ & 8-9 & 29-37 & 30-35 & $5-14$ & $2-3$ & $0.7-1.0$ & $1.1-1.8$ & $1.6-1.8$ \\
\hline
\end{tabular}

3HB: 3-hydroxybutyric acid, 3HHx: 3-hydrodxyhexanoic acid, 3HO: 3-hydroxyoctanoic acid, 3HD: 3-hydroxydecanoic acid, 3HDD: 3-hydroxydodecanoic acid, 3HTD: 3-hydroxytetradecanoic acid.

\subsection{Conclusion}

In this work, we tested Pseudomonas sp as bacterial strains to utilize fatty substrates and produce mcl-PHA. C. sativa has several favorable agronomic characteristics which give it potential to obtaining bio-based products and was shown to be a suitable substrate for production of mcl-PHA. This non-food vegetable oil, which had previously not been tested, gave good results for $P$. resinovorans DSM 21078 without any pre-treatment. The strain produced $3 \mathrm{~g}$ PHA per liter in discontinuous culture and $13.5 \mathrm{~g}$ PHA per liter in bioreactor fedbatch culture with additions of Camelina oil pulses during fermentation. Thus, this study shows the first steps in the development of a sustainable process for the production of bioplastics using oil from $C$. sativa which is a low-input crop with high per acre yield and does not interfere with food industry. Further studies and optimization of the process could provide the productivity gains required to improve cost effectiveness. 


\section{References}

Ahn, W.S., Park, S.J., Lee, S.Y. (2000) Production of Poly (3-hydroxybutyrate) by fed-batch culture of recombinant Escherichia coli with a highly concentrated whey solution. Appl Environ Microbiol 66(8): 3624-3627.

Ashby, R.D., Foglia, T.A. (1998) Poly (hydroxyalkanoate) byosynthesis from triglyceride substrates. Appl Microbiol Biotechnol 49: 431-437.

Atabani, A., Silitonga, A., Ong, H., Mahlia, T., Masjuki, H., Badruddin, I.A., Fayaz, H. (2013) Non-edible vegetable oils: A critical evaluation of oil extraction, fatty acid compositions, biodiesel production, characteristics, engine performance and emissions production. Renew Sust Energ Rev 18: 211-245.

Berti, M., Gesch, R., Eynck, C., Anderson, J., Cermak, S. (2016) Camelina uses, genetics, genomics, production, and management. Ind crop prod. 94: 690-710.

Braunegg G., Bona R., Koller M. (2004) Sustainable polymer production. Polym Plast Technol Eng. 43(6): 1779-1793.

Brigham, C.J., Sinskey, A.J. (2012) Applications of polyhydroxyalkanoates in the medical industry. Int J Biotechnol Wellness Ind 1(1): 52-60.

Carlsson, A.S. (2009) Plant oils as feedstock alternatives to petroleum-A short survey of potential oil crop platforms. Biochimie 91(6): 665-670.

Chanprateep, S. (2010) Current trends in biodegradable polyhydroxyalkanoates. J Biosci Bioeng 110(6): 621-632.

Chen, G.Q. (2009) A microbial polyhydroxyalkanoates (PHA) based bio- and materials industry. Chem Soc $\operatorname{Rev} 38(8):$ 2434-2446.

Chhetri, A.B., Tango, M.S., Budge, S.M., Watts, K.C., Islam, M.R. (2008) Non-edible plant oils as new sources for biodiesel production. Int J Mol Sci 9(2): 169-180.

Cruz, M.V., Freitas, F., Paiva, A., Mano, F., Dionisio, M., Ramos, A.M,, Reis, A.M. (2016) Valorization of fatty acids-containing wastes and byproducts into short-and medium-chain length polyhydroxyalkanoates. New Biotechnol 33(1): 206-215.

de Eugenio, L.I., Escapa, I.F., Morales, V., Dinjaski, N., Galan, B., Garcia, J.L., Prieto, M.A. (2010) The turnover of medium-chain-length polyhydroxyalkanoates in Pseudomonas putida KT2442 and the fundamental role of PhaZ depolymerase for the metabolic balance. Environ Microbiol 12(1): 207-221.

Hartmann, R., Hany, R., Pletscher, E., Ritter, A., Witholt, B., Zinn, M. (2006) Tailor-made olefinic medium- 
chain-length poly $[(R)$-3-hydroxyalkanoates] by Pseudomonas putida GPo1: Batch versus chemostat production. Biotechnol Bioeng. 93(4): 737-746.

Impallomeni, G., Ballistreri, A., Carnemolla, G.M., Guglielmino, S.P., Nicolo, M.S., Cambria, M.G. (2011) Synthesis and characterization of poly (3-hydroxyalkanoates) from Brassica carinata oil with high content of erucic acid and from very long chain fatty acids. Int J Biol Macromol 48(1): 137-145.

Khosravi-Darani, K., Mokhtari, Z.B., Amai, T., Tanaka, K. (2013) Microbial production of poly(hydroxybutyrate) from C1 carbon sources. Appl Microbiol Biotechnol 97: 1407-1424.

Khosravi-Darani, K., Bucci, D.Z. (2015) Application of poly (hydroxyalkanoate) in food packaging: Improvements by nanotechnology. Chem Biochem Eng Q 29(2): 275-285.

Koller, M. (2014) Poly (hydroxyalkanoates) for food packaging: Application and attempts towards implementation. Appl Food Biotechnol 1(1): 3-15.

Koller, M., Braunegg, G. (2015) Biomediated production of structurally diverse poly (hydroxyalkanoates) from surplus streams of the animal processing industry. Polimery 60: 298-308.

Koller, M., Marsalek, L., de Sousa Dias, M., Braunegg, G. (2017) Producing microbial polyhydroxyalkanoate (PHA) biopolyesters in a sustainable manner. New Biotechnol 37(A): 24-28.

Lageveen, R.G., Huisman, G.W., Preusting, H., Ketelaar, P., Eggink, G., Witholt, B. (1988) Formation of polyesters by Pseudomonas oleovorans: Effect of substrates on formation and composition of poly-(R)-3Hydroxyalkanoates and poly-(R)-3-Hydroxyalkenoates. Appl Environ Microbiol 54(12): 2924-2932.

Lee, S.Y., Wong, H.H., Choi, J., Lee, S.H., Lee, S.C., Han, C.S. (2000) Production of medium-chain-length polyhydroxyalkanoates by high-cell-density cultivation of Pseudomonas putida under phosphorus limitation. Biotechnol Bioeng 68(4): 466-470.

Malik, M.R., Yang, W., Patterson, N., Tang, J., Wellinghoff, R.L., Preuss, M.L., Burkitt, C., Sharma, N., Ji, Y., Jez, J.M., Peoples, O.P., Jaworski, J.G., Cahoon, E.B., Snell, K.D. (2015) Production of high levels of poly-3hydroxybutyrate in plastids of Camelina sativa seeds. Plant Biotechnol J 13(5): 675-688.

Marsudi, S., Unno, H., Hori, K. (2008) Palm oil utilization for the simultaneous production of polyhydroxyalkanoates and rhamnolipids by Pseudomonas aeruginosa. Appl Microbiol Biotechnol 78(6): 955-961.

Moldes, C., Garcia, P., Garcia, J.L., Prieto, M.A. (2004) In vivo immobilization of fusion proteins on bioplastics by the novel tag bioF. Appl Environ Microbiol 70(6): 3205-3212.

Moser, B.R. (2010) Camelina (Camelina sativa L.) oil as a biofuels feedstock: Golden opportunity or false hope?. Lipid Tech 22(12): 270-273. 
Muhr, A., Rechberger, E.M., Salerno, A. Reiterer, A., Schiller, M., Kwiecien, M., Adamus, G., Kowalczuk, M., Strohmeier, K., Schober, S., Mittelbach, M., Koller, M. (2013) Biodegradable latexes from animalderived waste: Biosynthesis and characterization of $\mathrm{mcl}$-PHA accumulated by Ps. citronellolis. React Funct Polym 73(10): 1391-1398.

Muhr, A., Rechberger, E.M., Salerno, A., Reiterer, A., Malli, K., Strohmeier, K., Schober, S., Mittelbach, M., Koller, M. (2013) Novel description of mcl-PHA biosynthesis by Pseudomonas chlororaphis from animal-derived waste. J Biotechnol 165: 45-51.

Prieto, M.A. (2007) From oil to bioplastics, a dream come true?. J Bacteriol 189(2): 289-290. doi:10.1128/JB.01576-06

Ramsay, B.A., Saracovan, I., Ramsay, J.A., Marchessault, R.H. (1992) Effect of nitrogen limitation on longside-chain poly-beta-hydroxyalkanoate synthesis by Pseudomonas resinovorans. Appl Environ Microbiol 58(2): 744-746.

Rodrigues, P.R., Druzian, J.I. (2018) Impact of different bacterial strains on the production, composition, and properties of novel polyhydroxyalkanoates using crude palm oil as substrate. Chem Biochem Eng $Q$ 32(1): 141-150.

Rodriguez-Perez, S., Serrano, A., Pantion, A.A., Alonso-Farinas, B. (2018) Challenges of scaling-up PHA production from waste streams. A review. J Environ Manage 205: 215-230.

Sainger, M., Jaiwal, A., Sainger, P.A., Chaudhary, D., Jaiwal, R., Jaiwal, P.K. (2017) Advances in genetic improvement of Camelina sativa for biofuel and industrial bio-products. Renew Sust Energ Rev 68: 623637.

Solaiman, D.K., Ashby, R.D., Foglia, T.A. (1999) Medium-chain-length poly ( $\beta$-hydroxyalkanoate) synthesis from triacylglycerols by Pseudomonas saccharophila. Curr Microbio/ 38(3): 151-154.

Solaiman, D., Ashby, R., Foglia, T. (2001) Production of polyhydroxyalkanoates from intact triacylglycerols by genetically engineered Pseudomonas. Appl Microbiol Biotechnol 56(5-6): 664-669.

Solaiman, D.K., Ashby, R.D., Foglia, T.A. (2002) Physiological characterization and genetic engineering of Pseudomonas corrugata for medium-chain-length polyhydroxyalkanoates synthesis from triacylglycerols. Curr Microbiol 44(3): 189-195.

Song, J.H., Jeon, C.O., Choi, M.H., Yoon, S.C., Park, W. (2008) Polyhydroxyalkanoate (PHA) production using waste vegetable oil by Pseudomonas sp. strain DR2. J Microbiol Biotechnol 18(18): 1408-1415.

Tan, I., Kumar, K.S., Theanmalar, M., Gan, S., Gordon lii, B. (1997) Saponified palm kernel oil and its major free fatty acids as carbon substrates for the production of polyhydroxyalkanoates in Pseudomonas 
putida PGA1. Appl Microbiol Biotechnol 47(3): 207-211.

Walsh, M., O'Connor, K., Babu, R., Woods, T., Kenny, S. (2015) Plant oils and products of their hydrolysis as substrates for polyhydroxyalkanoate synthesis. Chem Biochem Eng Q 29(2): 123-133.

Yun, H., Kim, D., Chung, C., Kim, H., Yang, Y., Rhee, Y. (2003) Characterization of a tachy poly(3hydroxyalkanoate) produced by Pseudomonas chlororaphis HS21 from Palm Kernel Oi. J Microbiol Biotechnol 13(1): 64-69.

Zanetti, F., Eynck, C., Christou, M., Krzyżaniak, M., Righini, D., Alexopoulou, E., Stolarski, M.J., Van Loo, E.N., Puttick, D., Monti, A. (2017) Agronomic performance and seed quality attributes of Camelina (Camelina sativa L. crantz) in multi-environment trials across Europe and Canada. Ind Crop Prod 107: $602-608$. 


\section{CHAPTER III}

Improved Raoultella planticola strains for the production of 2,3-butanediol from glycerol 


\subsection{Background and aim}

The alcohol 2,3-butanediol is naturally found in cacao butter and roots of Ruta graveolens. There is rising interest in this compound due to its many industrial applications, mainly for the chemical and energy industry. 2,3-BD (2,3-butanediol), as well as some derivatives, are employed in plastic and solvent production, such as octane booster in fuels, antifreeze agent or analytical reagent in the racemic separation of carbonyl compounds for gas chromatography (Białkowska, 2016; Harvey et al., 2016). One of the main applications of 2,3-BD is its conversion to 1,3-butadiene, employed in synthetic rubber production (Nguyen et al., 2018). Dyacetil, the dehydrogenation product of 2,3-BD, is a highly-valued flavor and bacteriostatic agent for the food industry. Moreover, dehydration of 2,3-BD yields methyl-ethyl-ketone (MEK), an additive with high combustion heat for fuels. MEK is also employed as solvent for resins and lacquers. Polyurethane-meliamides (PUMAs, which are useful for cardiovascular applications) are obtained from 2,3-BD esterification with malic acid. Other 2,3-BD esterification products are employed in the cosmetic and pharma industries. Other potential applications of 2,3-BD are the production of moistening and softening agents, elastane, fumigants, plasticizers, perfumes, printing inks and carriers for pharmaceuticals (Celińska and Grajek, 2009; Ji et al., 2011).

Nowadays, the economical production of many chemicals, including 2,3-BD, has been possible via chemical synthesis from fossil fuels, but it has now become necessary to develop new, environmentally friendly biotechnologies based on renewable resources (Białkowska, 2016). The first information on the subject was announced on the Lanzatech company website, http://www.lanzatech.com (access on August 24, 2018), with a technology that involves Clostridium strains and syngas as feedstock. Indeed, 2,3-BD production could be achieved by various bacterial strains belonging mainly to the genera Bacillus, Enterobacter, Klebsiella, Raoultella and Serratia (Yang et al., 2013; Shi et al., 2014; Ripoll et al., 2016). The most efficient 2,3-BD producers described so far are B. polymyxa, K. pneumoniae and $K$. oxytoca, mainly using sugars as substrates (Mallonee and Speckman, 1988; Ji et al., 2011).

Furthermore, there are well-known advantages of using industrial by-products (raw glycerol, whey or agriculture waste) for the production of chemicals. Due to economic and ecological concerns, the industrial production of 2,3-BD should utilize easily available and relatively cheap renewable resources, preferably by-products from the food and biofuel industries ( $\mathrm{Ji}$ et al., 2011). Considering that in biodiesel production approximately $100 \mathrm{~kg}$ of raw glycerol is produced per ton of product, it is very interesting to seek alternatives to upgrade this residual 
substrate. Thus, glycerol is one of the most promising substrates for 2,3-BD production (Parate et al., 2018).

To date the best 2,3-BD producers using glycerol are $K$. pneumoniae strains (Petrov and Petrova, 2009; Petrov and Petrova, 2010). This species also produces useful compounds as lactic acid, 3-hydroypropionic acid, ethanol, 1,3-propanediol and succinic acid, depending on the fermentation conditions (Bielb et al., 1998; Kumar and Park, 2018). However, $K$. pneumoniae is listed as a group risk 2 biological agent. This is a serious drawback as it is a pathogenic agent, which may cause infections in humans, thus posing a hazard for workers in contact with it (European Directive 20009/54/CD of European Parliament and European Council 18-9-2000) and makes it an unsuitable strain for industrial-scale fermentation.

The development of genetic engineering techniques and intensive studying of metabolic potential of microorganisms has allowed designing genetically modified microorganisms (GMOs), including K. oxytoca, K. pneumoniae or R. ornithinolytica strains, with higher yields of 2,3-BD from raw glycerol but they remain pathogenic [Cho et al., 2015; Rathnasing et al., 2016; Kim et al., 2017). Some wild type non-pathogenic Raoultella species such as Raoultella planticola and Raoultella terrigena strains (risk group 1) are able to produce 2,3-BD from pure glycerol and raw glycerol as sole carbon source without 1,3-propanediol formation (Ripoll et al., 2016; Rodriguez et al., 2017). However, the results are still lower than 2,3-BD titers obtained by $K$. pneumoniae possessing the 1,3-propanediol synthesis pathway (Petrov and Petrova, 2010).

The aim of this work is to describe a procedure to generate improved Raoultella planticola strains in order to obtain a better risk-1 biocatalyst for 2,3-BD production from glycerol as raw material and to contribute on the development of a safer and sustainable process to the production of a cost-competitive building block for the future bio-economy era (Koutinas et al., 2016).

\subsection{Materials and Methods}

\subsubsection{Strains, medium composition and culture conditions}

The wild-type strain Raoultella planticola CECT 843 was obtained from the Spanish Type Culture Collection (CECT), in Paterna (Valencia, Spain). After receiving the strain, it was recovered in the media recommended by the supplier (nutrient broth, NB) and stored in $20 \%$ 
glycerol for long-term preservation. Raoultella planticola strains CECT 8158 and CECT 8159 were obtained in this work by random mutagenesis.

Batch tests of 2,3-BD production were carried out in $50-\mathrm{mL}$ flasks, containing $10 \mathrm{ml}$ of the growth medium MB or MC. Medium MB composition was described by Nakashimada and coworkers (1998), with 30 or $60 \mathrm{~g}$ glycerol per liter. MC is a simpler medium, whose composition per liter is: $60 \mathrm{~g}$ glycerol, $1.5 \mathrm{~g}$ yeast extract, $0.42 \mathrm{~g}$ citric acid, $2 \mathrm{~g} \mathrm{NH}_{4} \mathrm{Cl}, 6 \mathrm{~g}$ $\mathrm{KH}_{2} \mathrm{PO}_{4}, 12 \mathrm{~g} \mathrm{Na}_{2} \mathrm{HPO}_{4}, 1 \mathrm{~g} \mathrm{NaCl}, 246 \mathrm{mg} \mathrm{MgSO} \cdot 7 \mathrm{H}_{2} \mathrm{O}, 14.7 \mathrm{~g} \mathrm{CaCl} \cdot 2 \mathrm{H}_{2} \mathrm{O}$. Inoculum was prepared in NB and added up to $1 \%\left(\mathrm{v} \mathrm{v}^{-1}\right)$ of the culture volume. Flasks were prepared in triplicates and incubated under aerobic conditions at $175 \mathrm{rpm}$ shaking, $28^{\circ} \mathrm{C}$ and an initial $\mathrm{pH}$ of 7. Samples were taken at 24 hours and bacterial growth was measured and, glycerol and product concentration were analyzed.

Fermentations were performed in Applikon ${ }^{\circledR} 1.5 \mathrm{~L}$ bioreactors with 0.5 working volume and the optimal conditions found in the experimental design optimization assay, with medium $M C$, and initial glycerol concentration of $60 \mathrm{~g} \mathrm{I}^{-1}$. The fermentation conditions were: $33^{\circ} \mathrm{C}, 500 \mathrm{rpm}$, and a oxygen saturation of $5 \%$. Initial pH was 6.8 , and was not time-course monitored, and was not controlled.

\subsubsection{Design of experiments and data interpretation}

Taguchi Method was used to enhance 2,3-BD production by using a design of orthogonal arrays, studying the influence of operational temperature and medium composition (glycerol initial concentration and $\mathrm{Co}^{2+}$ salt) with a reduced number of runs (Wojtusik et al., 2015). Two responses, called target functions, were selected: $2,3-B D$ production $\left(\mathrm{y}_{1}=[2,3-\mathrm{BD}]_{\max }\right)$, and $2,3-$ $B D$ yield $\left(y_{2}=Y_{2,3-B D / G I y c}\right)$. In contrast to traditional full or fractional factorial design and response surface methods, the Taguchi Method minimizes experimental work by means of a standard layout array. To examine the influence of three parameters at three levels, a standard $L_{9}$ orthogonal array was used, consisting of just nine runs in duplicates (Table 1). All intersections between parameters are assumed negligible. The assayed parameters were: initial glycerol concentration $\left(60,75,90 \mathrm{gl}^{-1}\right), \mathrm{CoCl}_{2}$ concentration $\left(0.012,0.024,0.036 \mathrm{~g} \mathrm{I}^{-1}\right)$, and temperature $\left(28,30,33^{\circ} \mathrm{C}\right)$. The oxygen saturation was kept fixed at $5 \%$ with $500 \mathrm{rpm}$ of agitation. The assays were performed in a micro-reactor (Applikon ${ }^{\circledR} \mu$-24 Bioreactor) with $3 \mathrm{~mL}$ of working volume using MB medium. Fermentations were finished at 24 hours. According to the Taguchi method, experimental data of response variables $\left(y_{1}\right.$ and $\left.y_{2}\right)$ were transformed into a Signal-toNoise $(\mathrm{S} / \mathrm{N})$ ratio for evaluating the performance of the system. For the $\mathrm{S} / \mathrm{N}$ ratio analysis, the 
correct function must be chosen as the-smaller-the-better, the-larger-the-better and thenominal-the-better. In the present work, the highest 2,3-BD yield and glycerol consumption were assayed. Data interpretation requires a comparison of the average values of $\mathrm{S} / \mathrm{N}$ ratios of three cutting factors at each level. The optimum level of each studied parameter corresponds to the highest $\mathrm{S} / \mathrm{N}$ ratio.

\subsubsection{Random mutagenesis and screening protocols}

i. $\quad$ Ethyl methane sulfonate (EMS) mutagenesis

For EMS mutagenesis, a R. planticola CECT 843 culture grown in medium MB with $30 \mathrm{~g} \mathrm{I}^{-1}$ of glycerol in exponential phase $\left(2 \times 10^{8} \mathrm{cfu} \mathrm{m}^{-1}\right)$ was employed. Cells were washed with phosphate buffer $0.1 \mathrm{M}$, and resuspended in the same volume buffer. The cell suspension was divided in $1 \mathrm{ml}$ - aliquots in Eppendorf tubes, to which different EMS volumes were added $(0,2$, $4,6,8,10$, and $20 \mu \mathrm{l}$ per $\mathrm{ml}$ of cell suspension). Incubation with EMS was for 1 hour at $30^{\circ} \mathrm{C}$. Afterwards, two washing steps were performed with the phosphate buffer and two more with sodium thiosulfate $10 \%\left(\mathrm{w} \mathrm{v}^{-1}\right)$ solution in order to neutralize the mutagenic agent (centrifugation steps during $15 \mathrm{~min}$ at $10.000 \mathrm{~g}$ ). Each cell pellet was transferred to a culture tube with $5 \mathrm{ml}$ of $\mathrm{MB}$ medium with $30 \mathrm{~g} \mathrm{I}^{-1}$ of glycerol, and incubated at $30^{\circ} \mathrm{C}$ for $16-18$ hours for cell recovery. Cell count was performed in NB plates to assess the death percentage of the treatment. The dosage chosen for mutant screening was $10 \mu \mathrm{L}$ per $\mathrm{mL}$ of EMS ( $95 \%$ cell death). The culture suspension (from $10 \mu \mathrm{l}$ per ml EMS dosage) was plated on selection plates with $\mathrm{NaBr} / \mathrm{NaBrO}_{3}\left(100 \mathrm{mM} \mathrm{NaBr}\right.$ and $100 \mathrm{mM} \mathrm{NaBrO}$ ), $12 \mathrm{~g} \mathrm{I}^{-1}$ glucose, $4 \mathrm{~g} \mathrm{l}^{-1}$ peptone, $1.2 \mathrm{~g} \mathrm{l}^{-1}$ meat extract, $2 \mathrm{~g} \mathrm{I}^{-1} \mathrm{NaCl}$ and $16 \mathrm{~g} \mathrm{I}^{-1}$ agar), and was incubated at $30^{\circ} \mathrm{C}$ for 2-3 days until colonies appeared. Previously, different $\mathrm{NaBr} / \mathrm{NaBrO}_{3}$ ratios and $\mathrm{pH}$ values had been tested: $\mathrm{Br}$ $/ \mathrm{BrO}_{3}{ }^{-} 160 / 40 \mathrm{mM}, 130 / 32.5 \mathrm{mM}, 100 / 25 \mathrm{mM}$ and $100 / 100 \mathrm{mM} ; \mathrm{pH} 7.0,6.5$ and 6.0. The combination of 100/100 mM of each salt and pH 6.0 was chosen as it allowed the growth of enough colonies to be tested: proton suicide method of Cueto and Méndez (Cueto and Méndez, 1990). This method enables mutants with lower acid production to be selected, because those that produce organic acids are killed by the $\mathrm{Br}^{0}$ formed in the plate. As the production of organic acids competes with 2,3-BD production, lower acid production should result in increased 2,3-BD production.

ii. UV mutagenesis

For the UV mutagenesis procedure, $1 \mathrm{ml}$ of cell suspension washed with phosphate buffer 
$\left(2 \times 10^{8} \mathrm{cfu} \mathrm{ml}^{-1}\right)$ from an exponential growing culture, was inoculated on plates containing $\mathrm{NaBr} / \mathrm{NaBrO}_{3} 100 \mathrm{mM}$ at pH 6.0. As controls, serial dilutions of the cell suspension were plated on LB medium plates. Different UV exposure times were applied: 0, 15, 30, 45 and 60 seconds. The plates were incubated in the dark until colonies appeared. The exposure time of 45 seconds was chosen ( $95 \%$ death rate).

\section{iii. Mutant screening}

The isolated colonies obtained in the $\mathrm{NaBr} / \mathrm{NaBrO}_{3}$ plates from the two mutagenesis procedures were assayed for 2,3-BD and acetoin production in micro-titer plates with culture medium $\mathrm{MB}$ with $30 \mathrm{~g} \mathrm{I}^{-1}$ of glycerol at $28^{\circ} \mathrm{C}$ and $500 \mathrm{rpm}$, adding phenol red at $0.008 \% \mathrm{w} / \mathrm{v}$. Below pH 6.4 this indicator turns yellow, enabling the rejection of those mutants lowering $\mathrm{pH}$ below this value, and the selection of those producing less acids. Colorimetric assays for acetoin and 2,3-BD detection were performed as described below. Following this method, up to 650 mutants were analyzed. Those that gave positive for acetoin and 2,3-BD production (24 mutants) were kept for further fermentation assays.

\subsubsection{Analytical methods}

Cell concentration was determined by means of optical density measurements at $600 \mathrm{~nm}$ (Eppendorf Biophotometer) or by cell dry weight (CDW) from freeze-dried samples. Additionally, $\mathrm{pH}$ values were measured with a selective $\mathrm{pH}$-meter (Crison $\mathrm{pH}$-meter Basic 20+). Cells were separated from cultures by centrifugation $\left(14,000 \times \mathrm{g} / 10 \mathrm{~min}, 20{ }^{\circ} \mathrm{C}\right.$ ) (Eppendorf Centrifuge 5425) in order to analyse supernatant composition by HPLC. Glycerol, 2,3-BD and by-products (succinic acid, lactic acid, acetic acid, acetoin and ethanol) were detected and quantified using a refractive index detector (Waters 2695 HPLC with a Refractive index detector 2414), after separating them in an Rezex ROA-Organic Acid column (Phenomenex). The column was operated at $65^{\circ} \mathrm{C}$, and $0.05 \mathrm{M}$ sulphuric acid was used as mobile phase, at a flow rate of $0.5 \mathrm{ml} \mathrm{min}^{-1}$. Colorimetric tests for the detection of 2,3-BD and acetoin were adapted for micro-titer plates from previous literature reports (Desnuelle and Naudet, 1945; Benjaminson et al., 1963; Speckman and Collins, 1982). For the assay of 2,3-BD in micro-titer plates $150 \mu \mathrm{l}$ of supernatant was mixed with $32 \mu \mathrm{l}$ of $\mathrm{H}_{5} \mathrm{IO}_{6} 0.1 \mathrm{M}$ and incubated for 30 minutes at room temperature. Afterwards, $20 \mu \mathrm{l}$ of ethylene glycol, $48 \mu \mathrm{L}$ of piperazine saturated solution $\left(30 \% \mathrm{w} \mathrm{v}^{-1}\right)$ and $16 \mu \mathrm{L}$ of sodium nitroprusside solution $\left(4 \% \mathrm{w} \mathrm{v}^{-1}\right)$ were added. $\mathrm{A}$ transient intense blue colour appears in response to the presence of 2,3-BD. The acetoin assay involved adding and mixing $100 \mu \mathrm{l}$ of culture supernatant, $12 \mu \mathrm{l}$ of creatine solution $(0.5 \% \mathrm{w}$ 
$\left.v^{-1}\right), 30 \mu$ of $\alpha$-naphthol in ethanol (solution at $5 \% w^{-1}$ ) and $20 \mu \mathrm{l}$ of $\mathrm{KOH}$ solution $\left(40 \% \mathrm{w} \mathrm{v}^{-1}\right)$. After 5-10 min, the mixture turns red if the assay is positive for acetoin, and the colour disappears after $30 \mathrm{~min}$.

\subsection{Results and Discussion}

\subsubsection{Optimization of fermentation conditions for the wild-type strain}

The strain Raoultella planticola CECT 843 was identified as one of the best producers of 2,3-BD from glycerol in a previous report (Ripoll et al., 2016). 2,3-BD biosynthesis plays a very important physiological role in microorganisms preventing acidification, regulating $\mathrm{NADH} / \mathrm{NAD}^{+}$, and storing carbon and energy for growth. In order to assess the optimal environmental parameters and medium composition, a Taguchi experimental design was adopted: the effect of temperature, initial glycerol concentration and initial cobalt concentration were assayed, employing MB medium. The influence of operational temperature is closely connected to enzymatic activity and cellular maintenance; while, in relation to medium composition, $\mathrm{Co}^{2+}$ possessed the most important influence among all bivalent ions [Petrov and Petrova, 2009; Dai et al., 2011). The dissolved oxygen concentration was set at $5 \%$ in all cases because it has been reported that 2,3-BD production with Raoultella sp. strains is efficient under oxygen limiting conditions (Rodriguez et al., 2017). Statistical analysis of variability associated to each factor indicated that glycerol concentration, temperature and cobalt-salt concentration significantly influenced the objective functions. The $\mathrm{pH}$ value was set at 6.8 at the beginning of the assay and was not controlled during fermentation. The experimental results are given in Table 1 and the optimal levels for each factor are shown in Figure 1. In general, temperature range between 30 and $37^{\circ} \mathrm{C}$ is the optimum for cell growth and fermentation; in this case results are better when temperature was increased between $28-33^{\circ} \mathrm{C}$ because it resulted in a substantial reduction in ethanol synthesis in favor of 2,3-BD formation (Ripoll et al., 2016), but under applied conditions a temperature of $33^{\circ} \mathrm{C}$ appeared to be optimal. Changes in temperature had little effect on 2,3BD formation (Celińska and Grajek, 2009). On the other hand, the excess substrate can cause inhibition of the strain, which apparently occurs at high concentrations of glycerol while the cobalt ion seems to play an important role in the synthesis of 2,3-BD. Therefore, to increase 2,3-BD production, yield and glycerol consumption the best conditions were $33^{\circ} \mathrm{C}, 60 \mathrm{~g} \mathrm{I}^{-1}$ of 
initial glycerol concentration and $0.036 \mathrm{~g} \mathrm{I}^{-1}$ of $\mathrm{CoCl}_{2}$. A batch-fermentation assay in 1.5 liter bioreactor was performed with the wild-type strain at the optimal conditions determined in the variable optimization assay. All the glycerol was consumed during the cultivation, and a 2,3-BD concentration of $22 \mathrm{~g} \mathrm{I}^{-1}$ was obtained, with a yield of 0.34 gram of 2,3-BD per gram of glycerol, which is $55 \%$ of the theoretical yield, $0.62 \mathrm{~g}$ of $2,3-\mathrm{BD}$ per gram of glycerol obtained from an electron balance (Ripoll et al., 2016).

Table 1. Experimental layout using an $L_{9}$ orthogonal array. Selected parameters and their levels.

\begin{tabular}{|c|c|c|c|c|c|c|c|}
\hline \multirow[b]{2}{*}{ Exp. } & \multicolumn{3}{|c|}{ Factors } & \multicolumn{4}{|l|}{ Results } \\
\hline & $\begin{array}{l}\mathrm{T} \\
\left({ }^{\circ} \mathrm{C}\right)\end{array}$ & $\begin{array}{r}\text { [Glyc] } \\
\left(\mathrm{g} \mathrm{I}^{-1}\right)\end{array}$ & $\begin{array}{l}{\left[\mathrm{CoCl}_{2}\right]} \\
\left(\mathrm{g} \mathrm{l}^{-1}\right)\end{array}$ & $\begin{array}{l}\text { CDW } \\
\left(\mathrm{g} \mathrm{l}^{-1}\right)\end{array}$ & $\begin{array}{l}{[2,3-B D]_{\max }} \\
\left(\mathrm{g} \mathrm{l}^{-1}\right)\end{array}$ & $\begin{array}{l}{[\mathrm{Glyc}]_{\text {cons }}} \\
\left(\mathrm{g} \mathrm{I}^{-1}\right)\end{array}$ & $\begin{array}{l}Y_{2,3-B D / G l y c} \\
\left(g^{-1}\right)\end{array}$ \\
\hline E1 & $28(1)$ & $75(2)$ & $0.036(3)$ & $6.0 \pm 1.5$ & $18.0 \pm 2.1$ & $37.9 \pm 2.7$ & $0.24 \pm 0.02$ \\
\hline E2 & $30(2)$ & $60(1)$ & $0.012(1)$ & $6.5 \pm 0.5$ & $14.2 \pm 3.4$ & $34.6 \pm 1.6$ & $0.24 \pm 0.04$ \\
\hline E3 & $33(3)$ & $90(3)$ & $0.024(2)$ & $3.8 \pm 1.0$ & $20.4 \pm 1.7$ & $23.3 \pm 3.6$ & $0.23 \pm 0.03$ \\
\hline E4 & $28(1)$ & $90(3)$ & $0.012(1)$ & $7.7 \pm 0.7$ & $15.2 \pm 1.6$ & $27.0 \pm 2.4$ & $0.17 \pm 0.01$ \\
\hline E5 & $30(2)$ & $75(2)$ & $0.024(2)$ & $8.4 \pm 0.3$ & $19.1 \pm 3.3$ & $40.0 \pm 3.3$ & $0.25 \pm 0.02$ \\
\hline E6 & $33(3)$ & $60(1)$ & $0.036(3)$ & $10.6 \pm 1.3$ & $22.3 \pm 4.5$ & $54.4 \pm 4.1$ & $0.37 \pm 0.05$ \\
\hline E7 & $28(1)$ & $60(1)$ & $0.024(2)$ & $6.0 \pm 0.8$ & $15.5 \pm 2.4$ & $33.9 \pm 1.2$ & $0.26 \pm 0.03$ \\
\hline E8 & $30(2)$ & $90(3)$ & $0.036(3)$ & $8.3 \pm 0.7$ & $18.0 \pm 3.7$ & $26.6 \pm 0.9$ & $0.20 \pm 0.01$ \\
\hline E9 & $33(3)$ & $75(2)$ & $0.012(1)$ & $8.4 \pm 0.2$ & $14.0 \pm 2.6$ & $32.3 \pm 1.8$ & $0.19 \pm 0.03$ \\
\hline
\end{tabular}

[2,3-BD]max= maximum 2,3-BD concentration achieved; [Glyc]cons= consumed glycerol concentration; $\mathrm{Y} 2,3-\mathrm{BD} / \mathrm{Glyc}=$ fermentation yield, grams of 2,3-BD obtained with respect to the grams of glycerol consumed.
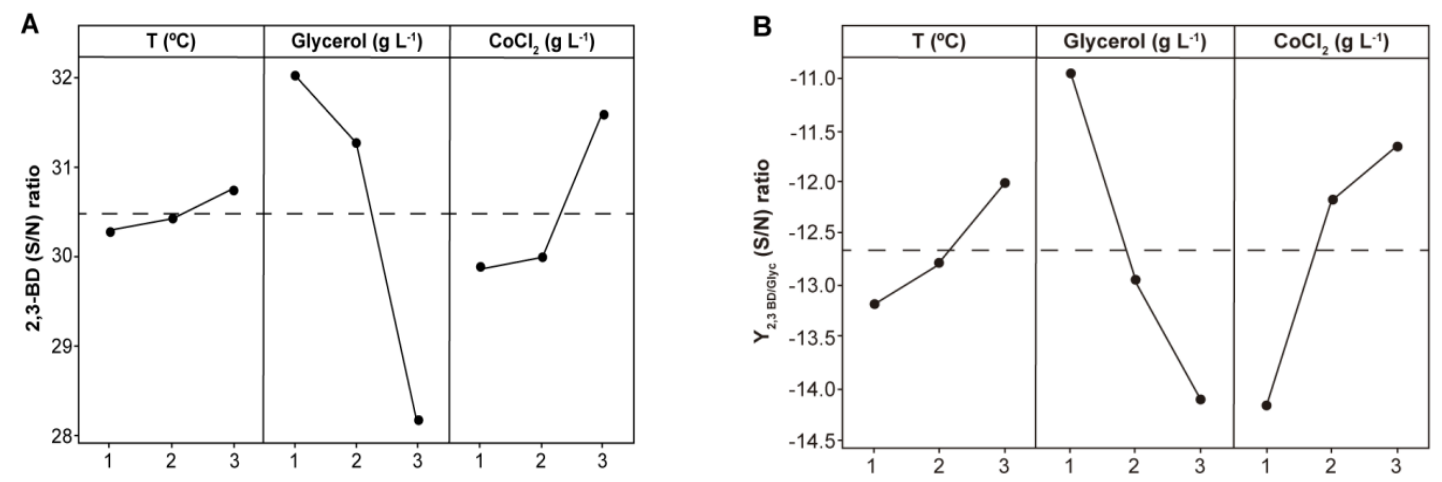

Figure 1. Effect of the variables on the production of 2,3-BD by Raoultella planticola CECT 843 (S/N ratio). (A) Effect of the variables on the 2,3-BD production. (B) Effect of the variables on the yield for the 2,3-BD production. Results were analyzed by Taguchi method. 


\subsubsection{Mutation of Raoultella planticola CECT843 and selection of the 2,3-BD overproducing strains}

A procedure to obtain overproducing 2,3-BD strains was employed with $R$. planticola CECT 843.

Cells were exposed to UV radiation or EMS followed by selection in plates with bromated/bromide (proton suicide method). In total, 650 mutants were analyzed, of which 24 were selected after micro-titer plate assays: those with low pH decrease (red phenol in the culture medium) and the production of acetoin and 2,3-BD (by colorimetric tests). These 24 selected strains were assayed in a micro-reactor device with the optimal fermentation conditions found for the wild-type strain. The results are shown in Table 2. Glycerol consumption, 2,3-BD production and cell growth were analyzed.

Table 2. Comparison of wild-type and mutant strains obtained by random mutagenesis.

\begin{tabular}{|c|c|c|c|c|c|}
\hline Strain & $\begin{array}{c}2,3-B D]_{\operatorname{maxc}} \\
\left(\mathrm{g} \mathrm{I}^{-1}\right)\end{array}$ & $\begin{array}{c}\text { Glyc }]_{\text {cons }} \\
\left(\mathrm{g} \mathrm{I}^{-1}\right)\end{array}$ & $\begin{array}{l}Y_{2,3-B D / G l y c} \\
\left(\mathrm{~g} \mathrm{~g}^{-1}\right)\end{array}$ & $\begin{array}{c}{[\text { Acet }]_{\max }} \\
\left(\mathrm{g} \mathrm{I}^{-1}\right)\end{array}$ & $\begin{array}{c}{[\text { [EtOH }]_{\max }} \\
\left(\mathrm{g} \mathrm{I}^{-1}\right)\end{array}$ \\
\hline СЕCT843 & $20.4 \pm 2.1$ & $47.2 \pm 2.9$ & $0.43 \pm 0.02$ & $1.5 \pm 0.4$ & $0.4 \pm 0.2$ \\
\hline $\mathrm{A} 1$ & $18.0 \pm 8.7$ & $38.9 \pm 1.5$ & $0.45 \pm 0.09$ & $0.9 \pm 0.05$ & $0.8 \pm 0.5$ \\
\hline $\mathrm{A} 2$ & $9.4 \pm 2.2$ & $22.5 \pm 5.7$ & $0.42 \pm 0.01$ & $1.6 \pm 0.08$ & $0.4 \pm 0.1$ \\
\hline A3 & $17.8 \pm 2.9$ & $35.3 \pm 6.3$ & $0.51 \pm 0.06$ & $0.9 \pm 0.4$ & $0.5 \pm 0.1$ \\
\hline A7 & $20.1 \pm 12.7$ & $40.6 \pm 2.7$ & $0.49 \pm 0.03$ & $2.0 \pm 1.6$ & $0.3 \pm 0.4$ \\
\hline C3 & $12.2 \pm 2.4$ & $27.4 \pm 4.1$ & $0.45 \pm 0.02$ & $0.9 \pm 0.2$ & $0.5 \pm 0.1$ \\
\hline E1 & $4.2 \pm 2.2$ & $14.1 \pm 6.2$ & $0.29 \pm 0.03$ & $1.5 \pm 0.4$ & $0.2 \pm 0.1$ \\
\hline E12 & $3.9 \pm 1.0$ & $15.9 \pm 1.8$ & $0.24 \pm 0.04$ & $1.3 \pm 0.4$ & $0.3 \pm 0.1$ \\
\hline F6 & $11.1 \pm 2.2$ & $29.8 \pm 2.8$ & $0.38 \pm 0.09$ & $0.8 \pm 0.2$ & $0.2 \pm 0.1$ \\
\hline F11 & $9.8 \pm 1.1$ & $28.2 \pm 2.8$ & $0.35 \pm 0.01$ & $0.7 \pm 0.2$ & $0.3 \pm 0.1$ \\
\hline $\mathrm{H} 7$ & $21.3 \pm 2.7$ & $42.5 \pm 9.9$ & $0.51 \pm 0.06$ & $1.3 \pm 0.6$ & $1.0 \pm 0.5$ \\
\hline $\mathrm{H} 10$ & $19.4 \pm 1.1$ & $40.6 \pm 0.1$ & $0.48 \pm 0.03$ & $1.1 \pm 0.2$ & $0.4 \pm 0.1$ \\
\hline IA1 & $20.7 \pm 0.7$ & $45.1 \pm 2.5$ & $0.46 \pm 0.01$ & $1.2 \pm 0.1$ & $0.6 \pm 0.1$ \\
\hline IA11 & $2.3 \pm 0.2$ & $13.7 \pm 1.0$ & $0.17 \pm 0.02$ & $1.3 \pm 0.1$ & $0.2 \pm 0.1$ \\
\hline IA12 & $20.4 \pm 1.6$ & $44.1 \pm 0.3$ & $0.46 \pm 0.03$ & $1.4 \pm 0.8$ & $0.4 \pm 0.1$ \\
\hline IB12 & $10.9 \pm 3.6$ & $30.2 \pm 5.6$ & $0.37 \pm 0.10$ & $1.3 \pm 1.1$ & $0.4 \pm 0.1$ \\
\hline $\mathrm{IH} 1$ & $17.0 \pm 5.8$ & $45.1 \pm 4.1$ & $0.37 \pm 0.10$ & $1.9 \pm 0.9$ & $0.3 \pm 0.1$ \\
\hline IIA12 & $19.4 \pm 8.3$ & $41.3 \pm 4.1$ & $0.46 \pm 0.20$ & $1.0 \pm 0.4$ & $0.5 \pm 0.1$ \\
\hline IIB2 & $11.9 \pm 1.1$ & $37.2 \pm 2.7$ & $0.32 \pm 0.05$ & $0.7 \pm 0.0$ & $0.3 \pm 0.1$ \\
\hline IIB12 & $19.2 \pm 0.9$ & $45.3 \pm 0.7$ & $0.42 \pm 0.01$ & $1.9 \pm 1.0$ & $0.5 \pm 0.1$ \\
\hline IIC12 & $21.4 \pm 6.4$ & $45.5 \pm 3.8$ & $0.47 \pm 0.10$ & $2.2 \pm 1.2$ & $0.3 \pm 0.1$ \\
\hline IIIA1 & $21.3 \pm 2.3$ & $45.1 \pm 3.6$ & $0.51 \pm 0.07$ & $1.4 \pm 0.7$ & $0.5 \pm 0.2$ \\
\hline IIIA3 & $21.8 \pm 3.1$ & $44.3 \pm 4.1$ & $0.49 \pm 0.05$ & $2.1 \pm 0.6$ & $0.3 \pm 0.1$ \\
\hline IIIA5 & $12.0 \pm 0.8$ & $28.0 \pm 1.3$ & $0.43 \pm 0.03$ & $0.8 \pm 0.2$ & $0.4 \pm 0.2$ \\
\hline IIIC9 & $11.7 \pm 1.1$ & $37.4 \pm 2.5$ & $0.31 \pm 0.02$ & $0.7 \pm 0.3$ & $0.2 \pm 0.1$ \\
\hline
\end{tabular}

$[2,3-\mathrm{BD}]_{\max }=$ maximum $2,3-\mathrm{BD}$ concentration achieved; $[\mathrm{Glyc}]_{\text {cons }}=$ consumed glycerol concentration; $[\text { Acet }]_{\max }=$ maximum acetoin concentration produced; $[\mathrm{EtOH}]_{\max }=$ maximum ethanol concentration produced; $\mathrm{Y}_{2,3-\mathrm{BD} / \mathrm{Glyc}}=$ fermentation yield, grams of 2,3-BD obtained with respect to the grams of glycerol consumed. 
Seven of these strains (A7, H7, IA1, IA12, IIC12, IIIA1 and IIIA3) were selected according to 2,3BD concentration and yield (Figure 2). Mutants IA1, IA12, IIC12, IIIA1 and IIIA3 come from the EMS procedure, whereas the $\mathrm{H} 7$ mutant was a spontaneous mutant obtained when the wildtype strain was grown in $\mathrm{NaBr} / \mathrm{NaBrO}_{3} 100 \mathrm{mM}$ plates. The $\mathrm{A} 7$ mutant was obtained with the UV mutagenesis procedure.

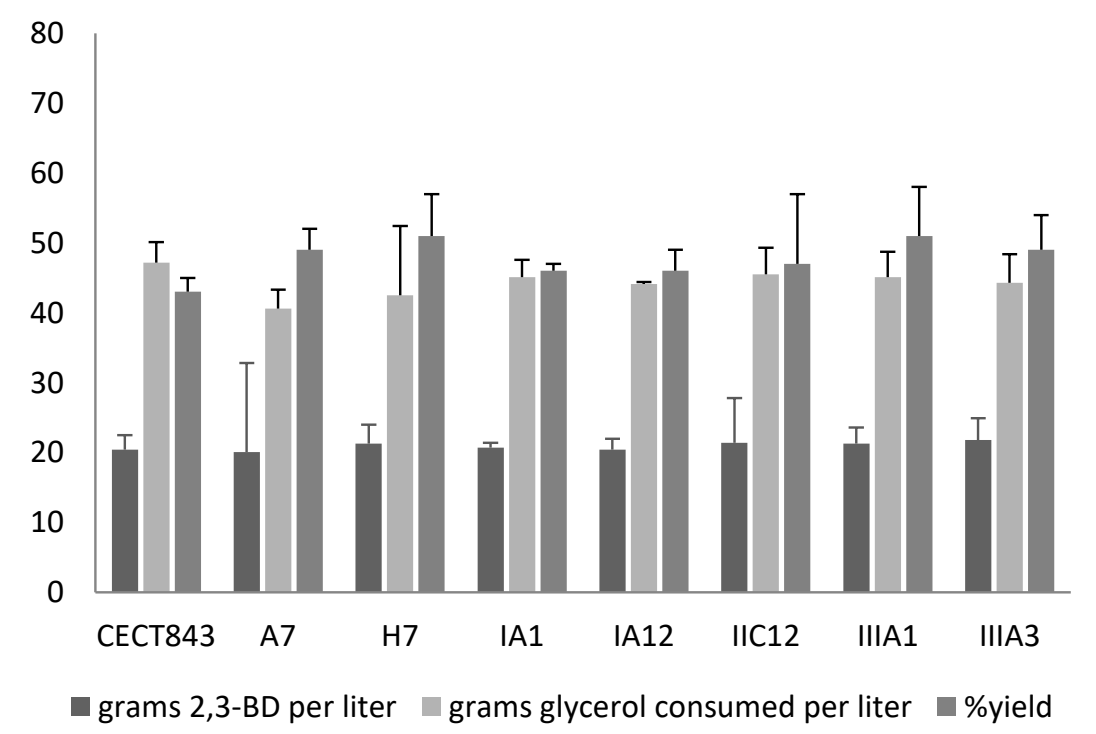

Figure 2. Comparison of wild-type and mutant strains obtained by random mutagenesis. 24 strains were tested in a micro-reactor with medium $\mathrm{MB}$ and $3 \mathrm{ml}$ of work volume (see Material and methods section) but strains A7, H7, IA1, IA12, IIC12, IIIA1 and IIIA3 showed the best yields.

These seven strains were tested again at bioreactor scale with the optimized conditions found previously for the wild type strain by Taguchi method (Table 3). The assays were performed to confirm the previous results at higher scale and to select the best producers. Figure 3 shows that the 2,3-BD concentration obtained for strains IA1 and IIIA3 (both obtained by random mutagenesis with $\mathrm{EMS}$ and selection in $\mathrm{NaBr} / \mathrm{NaBrO}{ }_{3}$ plates) is higher than that obtained with the other mutants. Mutants IA1 and IIIA3 produced more than $30 \mathrm{~g} \mathrm{I}^{-1}$ of 2,3-BD, with yields approximating the theoretical maximum for this transformation.

With the mutants IAI and IIIA3, especially mutant IA1, the yield is very close to the theoretical yield, to the best of our knowledge, this is the best result reported so far. In the case of $K$. pneumoniae, 1,3-propanediol is usually the main fermentation product. Although it is possible to modulate the process by aeration and pH-forced fluctuations (Petrov and Petrova, 2009; Petrov and Petrova, 2010), the maximum yield reported in these fermentations were 0.39 ( $w$ 
$\left.\mathrm{w}^{-1}\right)$. Another drawback of $K$. pneumoniae is its pathogenicity. In fact, attempts to remove pathogenicity factors of $K$. pneumoniae are being addressed (Shrivastav et al., 2013). Another recent reports described the conversion of glycerol to 2,3-BD with Serratia sp., with a yield of $0.43\left(\mathrm{w} \mathrm{w}^{-1}\right)$ (Huang et al., 2013) and $0.42\left(\mathrm{w} \mathrm{w}^{-1}\right)$ by a genetically modified Raoultella ornithinolytica strain and glycerol (Kim et al., 2017). However, unsurpassed yields of 0.50 (w w $\left.{ }^{1}\right)$ were achieved with the mutants obtained in this work.

Table 3. Comparison of wild-type and mutant strains obtained by random mutagenesis.

\begin{tabular}{|c|c|c|c|c|c|}
\hline Strain & $\begin{array}{c}{[2,3-B D]_{\max }} \\
\left(\mathrm{g} \mathrm{l}^{-1}\right)\end{array}$ & $\begin{array}{c}{[\mathrm{Glyc}]_{\text {cons }}} \\
\left(\mathrm{g} \mathrm{I}^{-1}\right)\end{array}$ & $\begin{array}{c}Y_{2,3-B D / G l y c} \\
\left(g^{-1}\right)\end{array}$ & $\begin{array}{c}\text { [Acet] }]_{\max } \\
\left(\mathrm{g} \mathrm{l}^{-1}\right)\end{array}$ & $\begin{array}{c}\text { [EtOH] }]_{\text {max }} \\
\left(\mathrm{g} \mathrm{l}^{-1}\right)\end{array}$ \\
\hline СЕСТ843 & $23.3 \pm 1.4$ & $64.7 \pm 0.1$ & $0.36 \pm 0.02$ & $6.7 \pm 0.2$ & $0.6 \pm 0.3$ \\
\hline IA1 & $30.8 \pm 3.9$ & $62.5 \pm 0.9$ & $0.49 \pm 0.07$ & $5.0 \pm 1.0$ & $0.5 \pm 0.2$ \\
\hline A7 & $27.4 \pm 5.2$ & $60.5 \pm 7.3$ & $0.45 \pm 0.06$ & $3.4 \pm 1.4$ & $0.2 \pm 0.1$ \\
\hline $\mathrm{H} 7$ & $25.3 \pm 7.8$ & $=7.3$ & $0.45 \pm 0.01$ & 3.6 & $0.4 \pm 0.2$ \\
\hline IA12 & $29.4 \pm 0.8$ & $63.2 \pm 0.7$ & $0.47 \pm 0.01$ & $5.0 \pm 0.7$ & $0.3 \pm 0.1$ \\
\hline IIC12 & $25.1 \pm 2.7$ & $56.0 \pm 7.1$ & $0.45 \pm 0.10$ & $2.0 \pm 1.0$ & $0.7 \pm 0.4$ \\
\hline IIIA1 & $30.1 \pm 3.3$ & $60.9 \pm 0.9$ & $0.49 \pm 0.07$ & $1.9 \pm 0.2$ & $0.9 \pm 0.4$ \\
\hline IIIA3 & $30.5 \pm 0.4$ & $57.6 \pm 5.5$ & $0.50 \pm 0.01$ & $2.4 \pm 1.5$ & $0.8 \pm 0.3$ \\
\hline
\end{tabular}

$[2,3-B D]_{\max }=$ maximum $2,3-\mathrm{BD}$ concentration achieved; $[\mathrm{Glyc}]_{\text {cons }}=$ consumed glycerol concentration; $[A c e t]_{\max }=$ maximum acetoin concentration produced; $[\mathrm{EtOH}]_{\max }=$ maximum ethanol concentration produced; $\mathrm{Y}_{2,3-\mathrm{BD} / \mathrm{Glyc}}=$ fermentation yield, 2,3-BD obtained with respect to glycerol consumed.

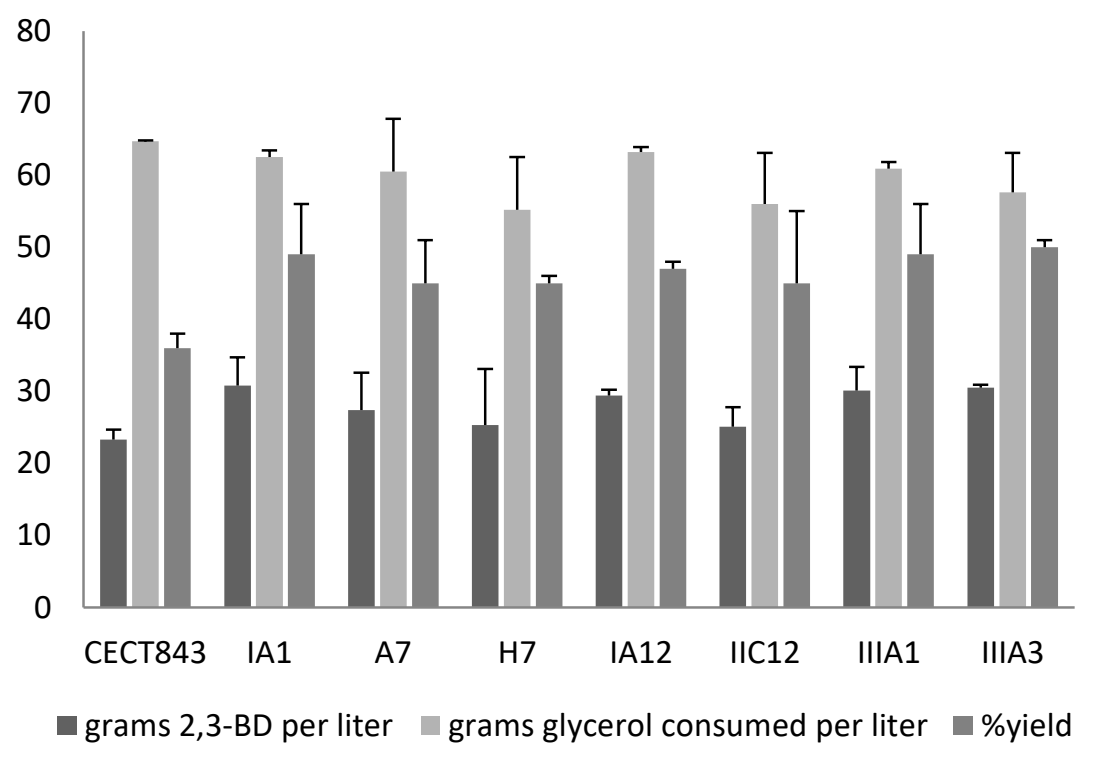

Figure 3. Second round of comparisons between wild type and selected mutants. Strains A7, H7, IA1, IA12, IIC12, IIIA1 and IIIA3 were tested in 1.5 I bioreactors with medium MB (see Material and methods section) to evaluate their performance at the optimum conditions. 


\subsubsection{Characterization of fermentation capacity of the mutant strains}

In the next fermentation assays, a simpler medium was chosen in order to develop a cheaper fermentation process. Fermentation was performed under the same optimized conditions as in the previous assays, with pure glycerol in $50 \mathrm{ml}$ flasks. The same fermentation procedure was employed for the wild-type and the two selected mutant strains. The results are shown in Table 3. Mutant IA1 produced $56 \%$ of $2,3-\mathrm{BD}$ and mutant IIIA3 $23.5 \%$ more $2,3-\mathrm{BD}$ than the wild-type strain. The results with this medium in flasks are not as good as those obtained with the richer medium MB due to the changes in composition. Another factor to consider is that aeration was not controlled in flask assays and the mass transfer is better in bioreactors. Therefore, the next step was to transfer this fermentation process to bioreactors in which aeration was properly controlled, keeping the simplest medium to make the process more economical. For the fermentation scale up in $1.5 \mathrm{~L}$ Applikon ${ }^{\circledR}$ bioreactors, the same MC medium and the optimized conditions for the wild-type strain were employed. Variables such as oxygen saturation and $\mathrm{pH}$ were established from previous 2,3-BD production studies (Fulgence et al., 2018). Although 2,3-BD is a product of anaerobic metabolism, aeration has been shown to enhance its production. Low oxygen availability maximizes 2,3-BD yield, but minimizes cell growth, therefore conversion rates are slow. By increasing oxygen supply, higher cell densities and higher production rates are obtained. However, too much aeration, exceeding the microbial oxygen demand, leads to biomass and carbon dioxide as products (Rodriguez et al., 2017). Therefore, fine-tuning of oxygen availability is required in order to optimize 2,3-BD production, so the $\mathrm{pO}_{2}$ was controlled at $5 \%$. The optimum $\mathrm{pH}$ depends on the microorganism and the substrate employed (Celińska and Grajek, 2009). For 2,3-BD production in $K$. oxytoca the optimum $\mathrm{pH}$ ranges from 5-6. For $K$. pneumoniae, according to Bielb and coworkers (Bielb et al., 1998) the lower the $\mathrm{pH}$, the higher the 2,3-BD final concentration. However, the best values were obtained when $\mathrm{pH}$ was not controlled (starting from $\mathrm{pH}$ 7). These authors suggested it is the presence of acetic acid rather than $\mathrm{pH}$ that triggers the shift to 2,3-BD synthesis, however acetic acid is a by-product that reduces the yield of 2,3-BD. Petrov and Petrova (2010) achieved the best 2,3-BD concentrations by forcing $\mathrm{pH}$ fluctuations. In this case, $\mathrm{pH}$ was left to develop without restraint.

The results of bioreactor assays are summarized in Table 4 . Mutant strains produce $52.7 \%$ and 39.5\% (IA1 and IIIA3 respectively) more 2,3-BD than the wild-type strain, reaching the maximum yield so far. These mutants have been deposited in the CECT collection under accession numbers CECT 8158 (mutant strain IA1) and CECT 8159 (mutant strain IIIA3). Finally, 
the optimal fermentation conditions were established for the wild-type strain, and these conditions are suitable for mutants, as the maximum yield is achieved. Concentration of organic acids such as succinic acid, lactic acid and acetic acid are very low or not detected under the conditions of the assays, particularly in bioreactor tests. Only acetoin and ethanol were detected by HPLC method (see Materials and methods section), then considering metabolic pathways of 2,3-BD production from glycerol, the fermentation conditions were properly optimized (Wojtusik et al., 2015, Rodrigez et al., 2017). The potential that lies in biocatalysts improving and intensified fermentation methods coupled with optimization procedures as well as making worthy fermentation systems will enable the development of bioprocesses to achieve 2,3-BD production efficiently (Fulgence et al., 2018).

Table 4. Flask and bioreactor fermentation results of $R$. planticola CECT 843 and mutants CECT 8158 (IA1) and CECT 8159 (IIIA3) with MC culture medium and the optimal conditions selected.

\begin{tabular}{|c|c|c|c|c|c|c|}
\hline Strain & Device & $\begin{array}{l}{[2,3-\mathrm{BD}]_{\max }} \\
\left(\mathrm{g} \mathrm{I}^{-1}\right)\end{array}$ & $\begin{array}{l}{[\text { Glyc }]_{\text {cons }}} \\
\left(\mathrm{g} \mathrm{I}^{-1}\right)\end{array}$ & $\begin{array}{l}Y_{2,3-B D / G l y c} \\
\left(\mathrm{~g} \mathrm{~g}^{-1}\right)\end{array}$ & $\begin{array}{l}{[\text { Acet }]_{\max }} \\
\left(\mathrm{g} \mathrm{I}^{-1}\right)\end{array}$ & $\begin{array}{l}{[\text { EtOH }]_{\max }} \\
\left(\mathrm{g}^{-1}\right)\end{array}$ \\
\hline \multirow{2}{*}{ СЕCT 843} & Flask & $15.0 \pm 1.2$ & $60.2 \pm 4.3$ & $0.25 \pm 0.02$ & $6.6 \pm 0.5$ & $2.4 \pm 0.1$ \\
\hline & Bioreactor & $22.0 \pm 4.1$ & $64.2 \pm 3.5$ & $0.34 \pm 0.05$ & $6.8 \pm 0.3$ & $0.9 \pm 0.1$ \\
\hline \multirow{2}{*}{ СЕCT 8158} & Flask & $23.4 \pm 2.3$ & $61.5 \pm 6.4$ & $0.38 \pm 0.01$ & $3.7 \pm 0.3$ & $1.9 \pm 0.2$ \\
\hline & Bioreactor & $33.6 \pm 1.5$ & $61.8 \pm 1.6$ & $0.54 \pm 0.06$ & $4.3 \pm 0.2$ & $0.5 \pm 0.1$ \\
\hline \multirow{2}{*}{ СЕCT 8159} & Flask & $18.5 \pm 2.1$ & $60.8 \pm 2.3$ & $0.30 \pm 0.04$ & $3.8 \pm 0.7$ & $1.2 \pm 0.3$ \\
\hline & Bioreactor & $30.7 \pm 3.5$ & $61.3 \pm 4.6$ & $0.50 \pm 0.02$ & $3.5 \pm 0.8$ & $0.8 \pm 0.2$ \\
\hline
\end{tabular}

$[2, \overline{3-B D}]_{\max }=$ maximum 2,3-BD concentration achieved; [Glyc $]_{\text {cons }}=$ consumed glycerol concentration; $[\text { Acet }]_{\max }=$ maximum acetoin concentration produced; $[\mathrm{EtOH}]_{\max }=$ maximum ethanol concentration produced; $\mathrm{Y}_{2,3-\mathrm{BD} / \mathrm{Glyc}}=$ fermentation yield, 2,3-BD obtained with respect to glycerol consumed.

\subsection{Conclusions}

As a conclusion it is possible to obtain improved biocatalysts for the conversion of glycerol to 2,3-BD with a high yield. These biocatalysts are improved mutants from a risk-1 $R$. planticola CECT 843 strain, obtained by random mutagenesis procedures; therefore, the new biocatalysts, $R$. planticola CECT 8158 and CECT 8159, are not genetically modified organisms. All these factors contribute to providing an alternative for biorefinery processes using glycerol as a potential substrate for valorization and establish the first steps in the development of safer and more sustainable processes. Experiments are underway to understand the genetic changes related with this hyperproducer phenotype and the industrial suitability of the strains. These results exceed the best data previously reported for 2,3-BD from glycerol. 


\section{References}

Benjaminson, M.A., de Guzmán, B.C., Weil, A.J. (1963) Voges-Proskauer test: expeditious techniques for routine use. J Bacterio/ 87: 234-235.

Białkowska, A.M. (2016) Strategies for efficient and economical 2,3-butanediol production: new trends in this field. World J Microbiol Biotechnol 32: 200.

Bielb, H., Zeng, A.-P., Menzel, K., Deckwer, W.-D. (1998) Fermentation of glycerol to 1,3-propanediol and 2,3-butanediol by Klebsiella pneumonia. Appl Microbiol Biotechnol 50: 24-29.

Celińska, E., Grajek, W. (2009) Biotechnological production of 2,3-butanediol-current state and prospects. Biotechnol Adv 27: 715-725.

Cho, S.; Kim, T., Woo, H.M., Kim, Y., Lee, J., Um, Y. (2015) High production of 2,3-butanediol from biodiesel-derived crude glycerol by metabolically engineered Klebsiella oxytoca M1. Biotechno Biofuels 8: 146 .

Cueto, P.H., Méndez, B.S. (1990) Direct selection of Clostridium acetobutylicum fermentation mutants by a proton suicide method. App Environ Microbiol 56: 578-580.

Dai, J.Y., Zhang, L.F., Xiu, Z.L. (2011) Al-2 Key enzyme S-Ribosylhomocysteinase from strain Klebsiella pneumoniae CICC 10011 producing 2,3-Butanediol. Chem Res Chinese Universities 27: 273-276.

Desnuelle, P., Naudet, M. (1945) Colorimetric determination of acetaldehyde formed on periodate oxidation of 2,3-BD. Bull Soc Chim Fr. 12: 871-8.

Fulgence, S., Yan, X., Cong, R. (2018) Current advances in the production of 2,3-butanediol by microbial fermentation. J Acad In. Res 6(10): 188-197.

Harvey, B.G., Merriman, W.W., Quintana, R.L. (2016) Renewable Gasoline, Solvents, and Fuel Additives from 2,3-Butanediol. ChemSusChem 9: 1814-1819.

Huang, C.F., Jiang, Y.F., Guo, G.L., Hwang, W.-S. (2013) Method of 2,3-butanediol production from glycerol and acid-pretreated rice straw hydrolysate by newly isolated strains: pre-evaluation as an integrated biorefinery process. Biores Technol 135:446-453.

Ji, X.J., Huang, H., Ouyang, P.K. (2011) Microbial 2,3-butanediol production: A state-of-the-art review. Biotechnol Adv 29: 351-364.

Kim, T., Cho, S., Woo, H.M., Lee, S., Lee, J., Um, Y., Seo, J. (2017) High production of 2, 3-butanediol from glycerol without 1,3-propanediol formation by Raoultella ornithinolytica B6. Appl Microbiol Biotechnol 101: $2821-2830$. 
Kumar, V., Park, S. (2018) Potential and limitations of Klebsiella pneumoniae as a microbial cell factory utilizing glycerol as the carbon source. Biotechnol Adv 36: 150-167.

Koutinas, A.A., Yepez, B., Kopsahelis, N., Freire, D.M., de Castro, A.M., Papanikolaou, S., Kookos, I.K. (2016) Techno-economic evaluation of a complete bioprocess for 2,3-butanediol production from renewable resources. Bioresour Technol 204: 55-64.

Mallonee, D.H., Speckman, R.A. (1988) Development of mutant strain of Bacillys polymyxa showing enhanced production of 2,3-butanediol. Appl Environm Microbiol 54: 168-171.

Nakashimada Y., Kanai, K., Nishio, N. (1998) Optimization of dilution rate, pH and oxygen supply on optical purity of 2,3-butanediol produced by Paenibacillus polymyxa in chemostat culture, Biotechnol Lett 20: 1133-8.

Nguyen, N.T.T, Matei-Rutkovska, F., Huchede, M., Jaillardon, K., Qingyi, G., Michel, C., Millet, J.M.M. (2018) Production of 1,3-butadiene in one step catalytic dehydration of 2,3-butanediol. Catal Today 323 : $62-68$.

Parate, R.D., Rode, C.V., Dharne, M.S. (2018) 2,3-Butanediol production from biodiesel derived glycerol. Curr Environ Eng 5:4-12.

Petrov, K., Petrova, P. (2009) High production of 2,3-butanediol from glycerol by Klebsiella pneumoniae G31. Appl Microbiol Biotechnol 84: 659-665.

Petrov, K., Petrova, P. (2010) Enhanced production of 2,3-butanediol from glycerol by forced $\mathrm{pH}$ fluctuations. Appl Microbiol Biotechnol 87: 943-949.

Rathnasingh, C., Park, J.M., Kim, D., Song, H., Chang, Y.K. (2016) Metabolic engineering of Klebsiella pneumoniae and in silico investigation for enhanced 2, 3-butanediol production. Biotechnol Lett 38: 975982.

Ripoll, V., de Vicente, G., Morán, B., Rojas, A., Segarra, S., Montesinos, A., Tortajada, M., Ramón, D., Ladero, M., Santos, V.E. (2016) Novel biocatalysts for glycerol conversion into 2,3-butanediol. Process Biochemistry 51: 740-748.

Rodriguez, A., Ripoll, V., Santos, V.E., Gomez, E., García-Ochoa, F. (2017) Effect of fluid dynamic conditions on 2,3-butanediol production by Raoultella terrigena in SBTR: oxygen transfer and uptake rates. J Chem Technol Biotechnol 92: 1266-1275.

Shi, L., Gao, S., Yu, Y., Yang, H. (2014) Microbial production of 2,3-butanediol by a newly-isolated strain of Serratia marcescens. Biotechno Lett 36: 969-973.

Shrivastav, A., Lee, J., Kim, H.Y., Kim, Y.R. (2013) Recent insights in the removal of Klebsiella 
pathogenicity factors for the industrial production of 2,3-butanediol. J Microbiol Biotechnol 23: 885-896.

Speckman, R.A., Collins, E.B. (1982) Specificity of the Westerfeld adaptation of the Voges Proskauer test. Appl Environ Microbiol 44(1): 40-43.

Wojtusik, M., Rodríguez, A., Ripoll, V., Santos, V.E., García, J.L., García-Ochoa, F. (2015) 1,3-Propanediol production by Klebsiella oxytoca NRRL-B199 from glycerol, Medium composition and operational conditions. Biotechnol Rep 6: 100-107.

Yang, T., Rao, Z., Zhang, X., Xu, M., Xu, Z., Yang, S. (2013) Improved production of 2,3-butanediol in Bacillus amyloliquefaciens by over-expression of glyceraldehyde-3-phosphate dehydrogenase and 2,3butanediol dehydrogenase. PLoS One 8: e76149. 


\section{CHAPTER IV}

Microbial production of 2,3-Butanediol from organic fraction of municipal solid waste 


\subsection{Background and aim}

2,3-butanediol (2,3-BD) is a compound of interest as a chemical reagent for use in different types of industries thanks to its unusual stereochemistry. It has 3 isomers: dextro-, levo- and meso-; and all three are produced by microbial fermentation (Ji et al., 2011). Levo-isomer freezes at $-60^{\circ} \mathrm{C}$, which makes it commercially interesting as antifreeze agent. Both dextro- and levo-isomers are excellent chiral components for asymmetric synthesis and are used in the pharmaceutical, agrochemical, fine chemical and food industries, and as a liquid crystals (Białkowska, 2016). Furthermore, 2,3-BD is easily dehydrated to methyl-ethyl-ketone (MEK), an excellent organic solvent for resins and lacquers; and to butadiene, for production of polyesters and polyurethanes (Nguyen et al., 2018). It can also be dehydrogenated in acetoin and diacetyl, which are flavoring agents in the dairy, margarine and cosmetic industries; and has potential applications in the production of inks, perfumes, softening and moisturizing agents, explosives, plasticizers and fuels (Celińska and Grajek, 2009; Harvey et al., 2016).

The production of 2,3-BD could be achieved by fermentation with various bacterial wild-type and engineered strains belonging mainly to the genera Klebsiella, Serratia, Bacillus, Paenibacillus, Enterobacter and Raoultella (Fulgence et al., 2018; Yang and Zhang, 2018). 2,3$\mathrm{BD}$ fermentation processes have the advantages of been less toxic than other alcohols, thus the culture can reach higher concentrations, the bioprocesses are less expensive than conventional processes and it is possible to use residual and renewable resources as glycerol, whey, starch, or sugars obtained in processes of enzymatic hydrolysis of ligno-cellulosic substrates as the carbon source (Ji et al., 2011; Białkowska, 2016). In fact, organic waste materials are interesting renewable resources that can be converted into different valueadded products obtained by sugar fermentation (Pagliano et al., 2017).

The waste accumulation in the environment has raised public awareness as a result of the linear economy and growing urban population. In EU in 2015, around 250 million tonnes of municipal solid waste (MSW) were generated, whereof $40-60 \%$ is organic waste (Matsakas et al., 2017). The organic fraction of municipal solid waste (OFMSW) has high moisture and salt content, leading to rapid decomposition and unpleasant odours. Moreover, it can generate greenhouse gas emissions, leachate and sanitary problems if not managed properly. However, it also represents a great resource for renewable energy production and for providing addedvalue products such as organic fertilizers, biopesticides and bioplastics within biorefinery technologies (Tonini et al., 2013; Fava et al., 2015). The biowaste refinery concept has received 
significant attention in recent years as a sustainable alternative to the petroleum refinery, and fermentation of carbohydrate feedstock to 2,3-BD is one of the attractive strategies due to high titers of 2,3-BD in the microbial broth (Celińska and Grajek, 2009; Jurchescu et al., 2013).

Due to economic and ecological concerns, the industrial production of 2,3-BD should utilize easily available and relatively cheap renewable resources, preferably by-products from the biofuel industry such as glycerol (Parate et al., 2018; Bustamante et al., 2019) or food and agricultural industry. In this context, previous studies include 2,3-BD production from apple pomace hydrolysate and biowastes by B. licheniformis (Białkowska et al., 2015; Rebechi et al., 2016), agricultural waste by Klebsiella sp. (Wong et al., 2012), Jerusalem artichoke tubers by $K$. pneumoniae (Sun et al., 2009) and P. polimyxa (Gao et al., 2010), food processing residues by B. amyloliquefaciens (Sikora et al., 2016), seaweed hydrolysate by an engineered Escherichia coli strain (Mazumdar et al., 2013) and fruit and vegetable waste from open markets (Liakou et al., 2018). To the best of our knowledge, OFMSW have not been evaluated as potential feedstock for the production of 2,3-BD considering the high quantities of material disposed and their high carbohydrate content (Matsakas et al., 2017). The use of low cost fermentation feedstocks could lead to significantly reduced 2,3-BD production cost (Koutinas et al., 2016).

The microorganisms of the species Bacillus licheniformis (Jurchescu et al., 2013, Rebecchi et al., 2016) and Raoultella ssp. (Drancourt et al., 2001; Kim et al., 2016) are potentially the most promising ones for the industrial production of 2,3-BD, both due to their production capacity comparable to that of the principal strains belonging to the genus Klebsiella, and for their lack of pathogenicity, as they belong to biosafety level 1.

In the present study, microbial 2,3-BD production from OFMSW hydrolysate was evaluated using Bacillus licheniformis and Raoultella planticolla strains as non-pathogenic microorganisms and considering OFMSW as a resource for the application in biorefineries for the production of high-added value products. This work presents a promising opportunity for coupling the waste and production sector in a future circular bioeconomy (Vea et al., 2018).

\subsection{Materials and Methods}

\subsubsection{Bacterial strains, media and growth conditions}

The bacterial strains employed in this study are Bacillus licheniformis DSM 8785 and Raoultella planticola strains CECT 843, CECT 8158 and CECT 8159. Cells were initially cultured in the 
media recommended by the supplier (nutrient broth, NB) and stored in $20 \%$ glycerol for longterm preservation. Solid media (nutrient agar, NA) were supplemented with $1.5 \%\left(\mathrm{w} \mathrm{v}^{-1}\right)$ agar. Seed cultures were prepared in flasks containing NB medium by incubating in a rotary shaker overnight at $30^{\circ} \mathrm{C}$ and $150 \mathrm{rpm}$.

The tolerance to OFMSW hydrolysate assays were carried out in $100 \mathrm{ml}$ flasks containing $20 \mathrm{ml}$ of culture in duplicates. The $\mathrm{pH}$ value was set to 7 and OFMSW hydrolysate was added at different concentrations ranging from 25 to $100 \%\left(v v^{-1}\right)$. Water was employed to dilute the hydrolysate at the different concentration tested.

Different culture media, including diluted OFMSW hydrolysate, were used to test 2,3-BD

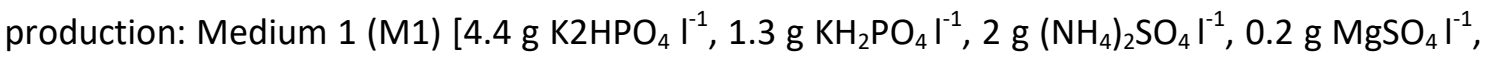
$1.0 \mathrm{~g}$ yeast extract $\mathrm{I}^{-1}$ and $1 \mathrm{ml}$ per liter of trace elements solution: $70 \mathrm{mg} \mathrm{ZnCl}_{2} \mathrm{I}^{-1}, 0.1 \mathrm{~g}$ $\mathrm{MnCl}_{2} \cdot 4 \mathrm{H}_{2} \mathrm{Ol}^{-1}, 60 \mathrm{mg} \mathrm{H}_{3} \mathrm{BO}_{3} \mathrm{I}^{-1}, 0.2 \mathrm{~g} \mathrm{CoCl}_{2} \mathrm{H}_{2} \mathrm{Ol}^{-1}, 20 \mathrm{mg} \mathrm{CuCl} \cdot 2 \mathrm{H}_{2} \mathrm{Ol}^{-1}, 25 \mathrm{mg} \mathrm{NiCl} \cdot 6 \mathrm{H}_{2} \mathrm{Ol}^{-1}, 35$ $\left.\mathrm{mg} \mathrm{Na} 2 \mathrm{MoO}_{4} \cdot 2 \mathrm{H}_{2} \mathrm{O} \mathrm{I}^{-1}, 0.9 \mathrm{~mL} \mathrm{HCl} \mathrm{l}{ }^{-1}\right]$ described by Cheng and colleagues (2010), Medium 2 (M2) [5.0 g yeast extract $\mathrm{I}^{-1}, 5.0 \mathrm{~g}$ triptone $\mathrm{I}^{-1}, 7.0 \mathrm{~g} \mathrm{KH}_{2} \mathrm{PO}_{4} \mathrm{I}^{-1}, 5.5 \mathrm{~g} \mathrm{~K}_{2} \mathrm{HPO}_{4} \mathrm{I}^{-1}, 1.0 \mathrm{~g}\left(\mathrm{NH}_{4}\right)_{2} \mathrm{SO}_{4} \mathrm{I}^{-}$ ${ }^{1}, 0.25 \mathrm{~g} \mathrm{MgSO}_{4} \cdot 7 \mathrm{H}_{2} \mathrm{Ol}^{-1}, 0.12 \mathrm{~g} \mathrm{NaMoO}_{4} \cdot 7 \mathrm{H}_{2} \mathrm{Ol}^{-1}, 0.021 \mathrm{~g} \mathrm{CaCl}_{2} \cdot 2 \mathrm{H}_{2} \mathrm{O} \mathrm{I}{ }^{-1}, 0.029 \mathrm{~g} \mathrm{CoCl}_{2} \cdot 6 \mathrm{H}_{2} \mathrm{Ol}^{-1}$, $0.039 \mathrm{~g} \mathrm{Fe}\left(\mathrm{NH}_{4}\right)_{2} \mathrm{SO}_{4} \cdot 6 \mathrm{H}_{2} \mathrm{Ol}^{-1}, 2 \mathrm{mg}$ nicotininic acid l ${ }^{-1}, 0.172 \mathrm{mg} \mathrm{Na}_{2} \mathrm{SeO}_{3} \mathrm{I}^{-1}, 0.02 \mathrm{mg} \mathrm{NiCl}_{2} \mathrm{l}^{-1}, 10$ $\mathrm{ml}$ per liter of trace elements solution: $0.5 \mathrm{~g} \mathrm{Na}_{2} \mathrm{EDTA} \mathrm{I}^{-1}, 0.5 \mathrm{~g} \mathrm{MnCl}_{2} \cdot 4 \mathrm{H}_{2} \mathrm{Ol}^{-1}, 0.1 \mathrm{~g} \mathrm{H}_{3} \mathrm{BO}_{3} \mathrm{I}^{-1}$, $1.0 \mathrm{mg} \mathrm{CuCl} 2 \cdot 2 \mathrm{H}_{2} \mathrm{O} \mathrm{I}^{-1}$ ] described by Nakashimada and colleagues (1998) and Medium 3 (M3)

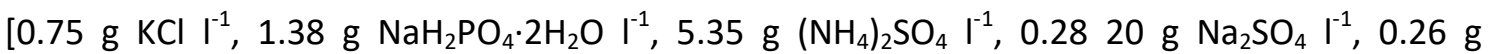
$\mathrm{MgSO}_{4} \cdot 7 \mathrm{H}_{2} \mathrm{Ol}^{-1}, 0.42 \mathrm{~g}$ citric acid l-1, $2 \mathrm{~g}$ yeast extract $\mathrm{l}^{-1}, 0.3 \mathrm{ml}$ per liter of trace elements solution: $34.2 \mathrm{~g} \mathrm{ZnCl}_{2} \mathrm{I}^{-1}, 2.7 \mathrm{~g} \mathrm{FeCl}_{3} \cdot 6 \mathrm{H}_{2} \mathrm{Ol}^{-1}, 10 \mathrm{~g} \mathrm{MnCl}_{2} \cdot 4 \mathrm{H}_{2} \mathrm{Ol}^{-1}, 0.85 \mathrm{~g} \mathrm{CuCl}_{2} \cdot 2 \mathrm{H}_{2} \mathrm{Ol}^{-1}, 0.3 \mathrm{~g}$ $\mathrm{H}_{3} \mathrm{BO}_{3} \mathrm{I}^{-1}, 23.8 \mathrm{~g} \mathrm{CoCl}_{2} \cdot 6 \mathrm{H}_{2} \mathrm{O} \mathrm{I}^{-1}$ ] described by Petrov and Petrova (2009). Initial hydrolysate concentration was $75 \%\left(\mathrm{v} \mathrm{v}^{-1}\right)$ at $\mathrm{pH}$ of 7 with subsequent feedings of $10 \mathrm{ml}$ of hydrolysate added at 16, 24 and $40 \mathrm{~h}$ of cultivation. Bacteria were incubated with stirring by triplicate, at $30^{\circ} \mathrm{C}$ and $150 \mathrm{rpm}$ during 48 hours. Cultures were inoculated at $5 \%\left(\mathrm{v} \mathrm{v}^{-1}\right)$ and growth was measured by counting viable cells at the beginning and the end of the cultures (colony forming units, CFU per $\mathrm{mL}$ ).

\subsubsection{Bioreactor assays}

Fermentations were performed in a $1.5 \mathrm{~L}$ Applikon ${ }^{\circledR}$ reactor with an initial volume of 0.5 liter and hydrolysate concentration of $80 \%\left(\mathrm{v} \mathrm{v}^{-1}\right)$. The fermentation conditions were: $30^{\circ} \mathrm{C}, 325$ rpm, and $1.5 \mathrm{vvm}$ of air flow rate. The $\mathrm{pH}$ was set to 6.5 and was adjusted, depending on the 
experiment, by the addition of $\mathrm{NaOH} 5 \mathrm{M}$. Substrate additions were done by adding 10 fold concentrated hydrolysate feedings during fermentations (feeding strategies are described in the results section for each assay). The bioreactors were inoculated with Raoultella planticola CECT 843 at $5 \%\left(v^{-1}\right)$ from NB precultures. Growth was monitored by $\mathrm{OD}_{600}$ absorbance using a centrifugated sample of the culture as the blank for each measurement, to take into account the interferers of the medium.

A technical scale fermentation was carried out in a 30L BIOSTAT-D bioreactor Sartorius). A total of 10 liter of hydrolysate at $80 \%\left(\mathrm{v} \mathrm{v}^{-1}\right)$ was used at $30^{\circ} \mathrm{C}$ and $\mathrm{pH}$ of 6.5 , adding when needed for $\mathrm{pH}$ control, $\mathrm{NaOH} 5 \mathrm{M}$. A double rushton turbine was used for agitation at $250 \mathrm{rpm}$ and aeration was set at $0.5 \mathrm{vvm}$. The reactor was inoculated with Roaultella planticolla CECT 843 at $5 \%\left(v^{-1}\right)$. The inoculum was prepared in $500 \mathrm{ml}$ of hydrolysate at $75 \%\left(\mathrm{v} \mathrm{v}^{-1}\right)$ with NB.

\subsubsection{OFMSW pretreatments}

Raw material samples were supplied by S.A. Agricultores de la Vega de Valencia (generated at an intermediate point through composting process of MSW. Pretreatment stages increased organic fraction of the material and therefore the samples were designated as OFMSW. Once in laboratory, OFMSW samples were stored at $-20^{\circ} \mathrm{C}$ until being treated. Total solids (TS) of the samples were measured using an infrared drying balance untill constant weight and distilled water was added in a relation of $20 \%\left(\mathrm{w} \mathrm{w}^{-1}\right)$ TS. The $\mathrm{pH}$ was adjusted to 5.2 with orthofosforic acid and then the mixture was autoclaved two times at $121^{\circ} \mathrm{C}$ for $1 \mathrm{~h}$ to eliminate microorganisms and spores. Samples were cooled down to room temperature and Cellic ${ }^{\circledR}$ Ctec2 enzymatic cocktail (Novozymes) was added at dose of $15 \%\left(\mathrm{w} \mathrm{w}^{-1}\right)$ of glucan fraction from OFMSW. Then, the mixture was incubated with stirring, at $50^{\circ} \mathrm{C}$ and $150 \mathrm{rpm}$ during $72 \mathrm{~h}$ in duplicates. Finally, the hydrolysate was centrifuged and liquid fraction was autoclaved at $121^{\circ} \mathrm{C}$ for $20 \mathrm{~min}$ and afterwards filtered through sterile Mira-cloth. OFMSW hydrolysates obtained were stored at $4^{\circ} \mathrm{C}$ until utilization. Some samples of hydrolysate were 10 fold concentrated by rotary evaporation under vacuum to prepare feedings for bioreactor asssays.

\subsubsection{Analytical procedures}

All reagents were supplied by Sigma-Aldrich and analyses were carried out in triplicates. Characterization of OFMSW was performed in triplicates following NREL methodology and by 
gravimetric tests of the samples received from the composting treatment of MSW (Sluiter et al., 2006, 2008ab, Jensen et al., 2011). Analysis of starch was performed with the Colorimetric Kit Megazyme K-TSHK Total Starch HK (Rapid, BIOCON. Barcelona, Spain). Protein was measured with a Thermo Fisher Commercial kit (BCA Protein Assay Kit; Pierce, Fisher ScientificSpain, Madrid, Spain). Fat was determined by soxhlet extraction of dried samples with chloroform. The content of sugars from hydrolysates (mainly glucose and xylose), 2,3-BD and by-products (succinic acid, lactic acid, acetic acid, acetoin and ethanol) were detected and quantified by HPLC using a refractive index detector (Waters 2695 HPLC with a Refractive index detector 2414), after separating them in an Rezex ROA-Organic Acid column (Phenomenex). The column was operated at $65^{\circ} \mathrm{C}$, and $0.05 \mathrm{M}$ sulphuric acid was used as mobile phase, at a flow rate of $0.5 \mathrm{ml} \mathrm{min}$.

\subsection{Results and discussion}

\subsubsection{Characterization of OFMSW and its use for 2,3-butanediol bioproduction}

The OFMSW samples used in this study were selected throughout the composting treatment at an intermediate point of the process (prior to screening, after trench outflow), which provides an adequate amount of carbohydrates and represents a saving by not completing the entire composting process (Table 1). Enzymatic hydrolysis assays were conducted with commercial cocktail of cellulases with hydrolysis yields of 45\%; therefore, around $25 \mathrm{~g} \mathrm{I}^{-1}$ of glucose and $5 \mathrm{~g} \mathrm{I}^{-1}$ of xylose were released. One of the advantages of this raw material is that, in contrast to pure lignocellulosic ones, physicochemical processing (i.e. acid hydrolysis, steam explosion) is not necessary, but due to its nature, hygienization methods at industrial scale must be taken into account. It is remarkable that enzymatic hydrolysis is the most efficient method to obtain monomeric sugars from organic waste avoiding the accumulation of growth inhibitors and therefore the hydrolysates are suitable to be directly used as fermentation media (Díaz et al., 2017). OFMSW hydrolysate tolerance assays with Bacillus licheniformis and Raoultella planticola strains were performed using diluted hydrolysate in distilled water at 25 , 50, 75 and 100\% ( $\mathrm{v} \mathrm{v}^{-1}$ ) (Figure 1). In a previous work (Jurchescu et al., 2013) Bacillus licheniformis DSM 8785 was selected as a suitable candidate for large-scale fermentation processes even using immobilized $B$. licheniformis in the form of LentiKats ${ }^{\circledR}$ and glucose as substrate. In the conditions of these assays this strain grew up from $4 \times 10^{8}$ to $2.5 \times 10^{9} \mathrm{CFU}$ $\mathrm{ml}^{-1}$ and was able to produce 2,3-BD up to a $50 \%\left(\mathrm{v} \mathrm{v}^{-1}\right)$ hydrolysate content, while Raoultella 
planticola CECT 843 tolerated the hydrolysate up to $75 \%\left(\mathrm{v} \mathrm{v}^{-1}\right)$ concentration (Figure 1) with a yield of 0.5 grams of 2,3-BD per gram of sugars and grew up from $9 \times 10^{8}$ to $1 \times 10^{11} \mathrm{CFU} \mathrm{\textrm {ml } ^ { - 1 }}$. In adittion, some $B$. licheniformis strains are not able to use and produce 2,3-BD from pentoses (Rebecchi et al., 2016) and as mentioned above, the main sugars found in the hydrolysate are glucose and xylose. Therefore, the following tests for 2,3-BD production from OFMSW hydrolysate were conducted using Raoultella planticola strains.

Table 1. Composition of OFMSW sample: fraction after trench outflow in the composting process of MSW. (triplicates).

\begin{tabular}{lc}
\hline Component & \% Dry weight $\left(\mathrm{w} \mathrm{w}^{-1}\right)$ \\
\hline Total solids & $62.4 \pm 3.3$ \\
Ashes & $40.7 \pm 2.5$ \\
Fats & $16.3 \pm 0.1$ \\
Extractive $\mathrm{H}_{2} \mathrm{O}$ & $12.9 \pm 0.6$ \\
Glucan & $25.7 \pm 3.6$ \\
Xylan & $2.5 \pm 0.1$ \\
Pectin & $11.6 \pm 0.6$ \\
Lignin & $5.3 \pm 0.5$ \\
Starch & $3.4 \pm 0.9$ \\
Protein & $5.5 \pm 0.7$ \\
\hline
\end{tabular}

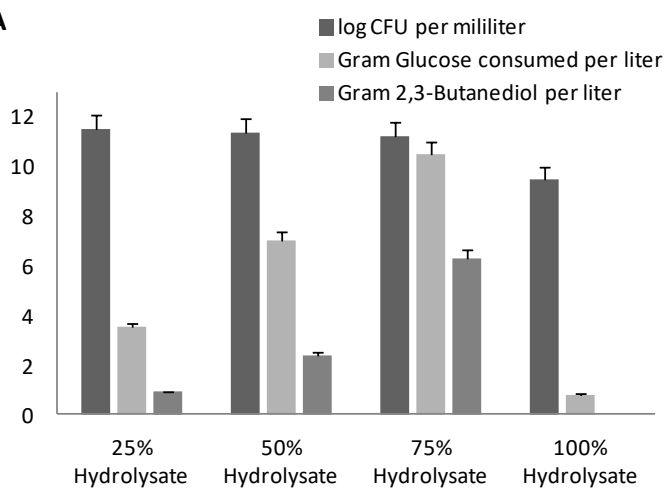

B

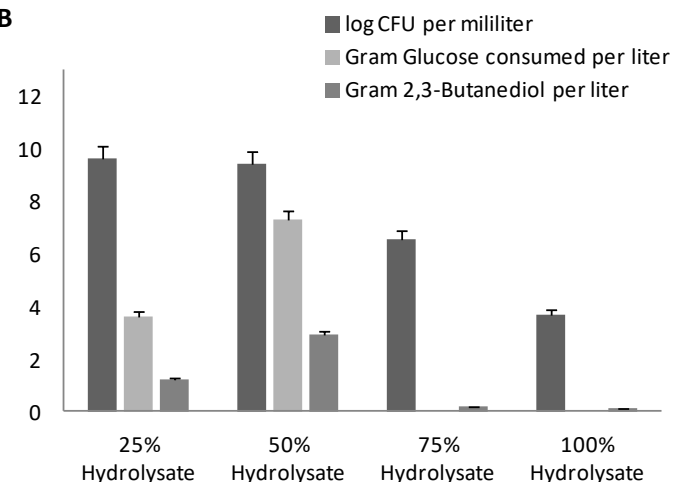

Figure 1. Tolerance Assays of Raoultella planticola CECT 843 (A) and Bacillus licheniformis DSM 8785 (B) at different concentrations of OFMW hydrolysate and 24 hours of cultivation.

\subsubsection{Production of 2,3-butanediol in flask cultures}

The 2,3-BD production can be improved by designing an adecuate cultivation strategy, wich require the control of substrate concentration (Cheng et al., 2010). The batch processes usually show low productivity and substrate inhibition can easily occur. For overcoming this problem, the constant addition of the substrate at an appropriate rate during the cultivation 
via fed-batch operation is preferred (Fulgence et al., 2018). Fed-batch assays were performed in flasks to compare formulated media $M 1, M 2, M 3$ and only diluted hydrolysate as culture medium with subsequent additions of substrate during fermentation (see Materials and methods section). Raoultella planticola CECT 843 was used as a reference strain because Raoultella planticola CECT 8159 and CECT 8159 are improved strains obtained in previous studies by random mutagenesis (Bustamante et al., 2019). The results are shown in Figure 2. This strategy allowed the amount of substrate available in the medium to be increased without inhibiting the growth of the strain. Sugars were totally consumed at $48 \mathrm{~h}$ of cultivation, 2,3-BD titer was around 14.5 grams per liter and theoretical yield, which is 0.5 gram of 2,3-BD per gram of sugars, was achieved (Jiayang et al., 2006). Same results are obtained in the case of hydrolysate without any supplementation of salts or nitrogen sources, which is highly advantageous in terms of process costs. However the cultures were diluted when feedings of hydrolysate were added and then 2,3-BD titers obtained during fermentation were still low.
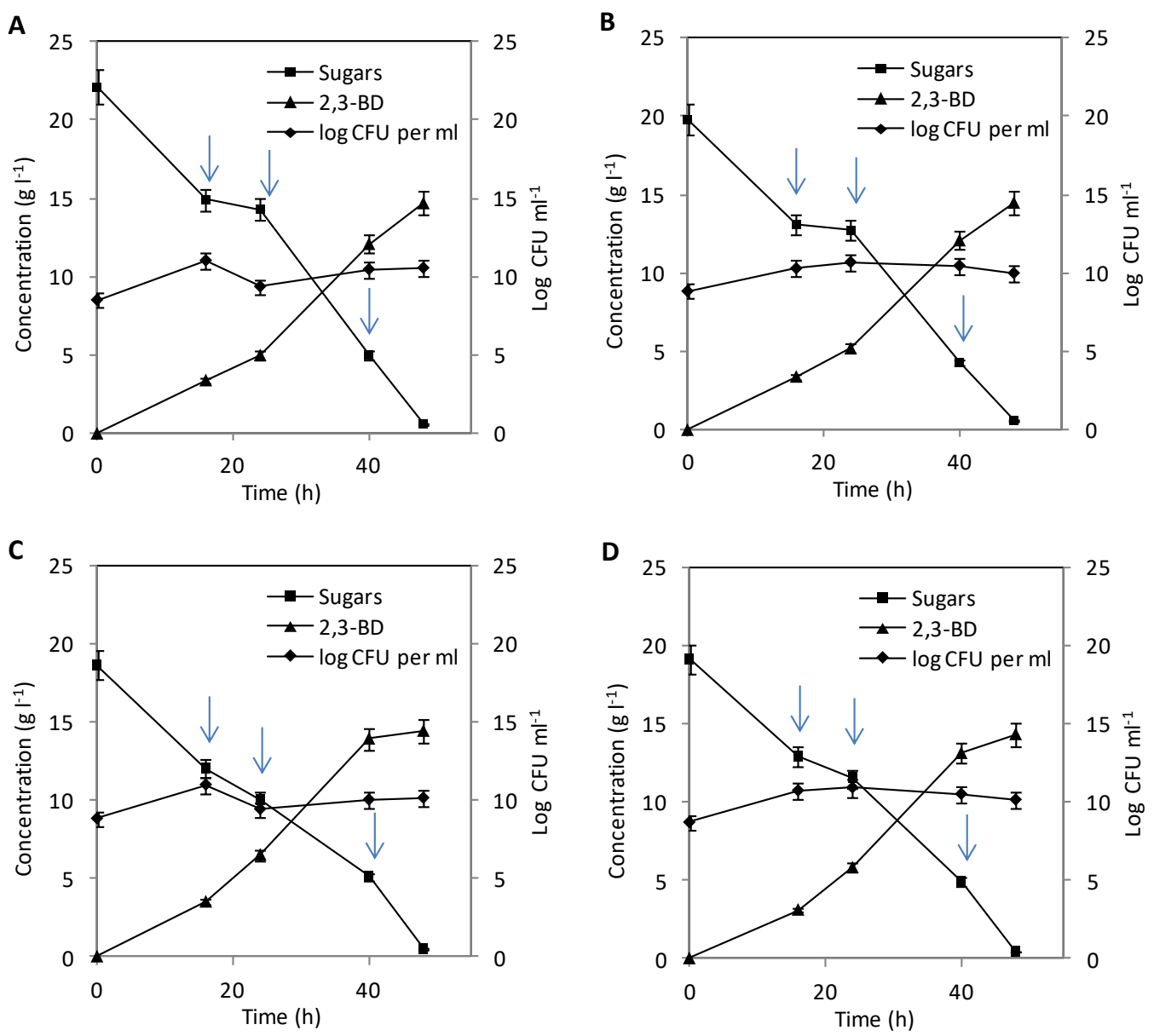

Figure 2. Fermentation of Raoultella planticola CECT 843 in fed-batch mode with OFMSW hydrolysate at $75 \%\left(v^{-1}\right)$ in flasks (A) and supplemented with medium M1 (B), Medium M2 (C) and medium M3 (D). 
Subsequently, improved strains, CECT 8158 and CECT 8159, were tested to evaluate their production capacity of 2,3-BD and the results showed that those strains behave in a similar way to the wild-type strain with OFMSW hydrolysate and flasks fed-batch strategy (Figure 3). Therefore, $R$. planticola strains tolerated OFMSW hydrolysate feedings and again reached yields of 0.5 gram of 2,3-BD per gram of sugars, corresponding to the maximum conversion yield (Białkowska, 2016; Fulgence et al., 2018). Raoultella planticola strains appear to have no special nutritional requeriments using OFMSW and showed robustness performance at this stage so further optimization and following bioreactor scale-up assays were performed using only Raoultella planticola CECT 843 as model strain without medium supplementation.
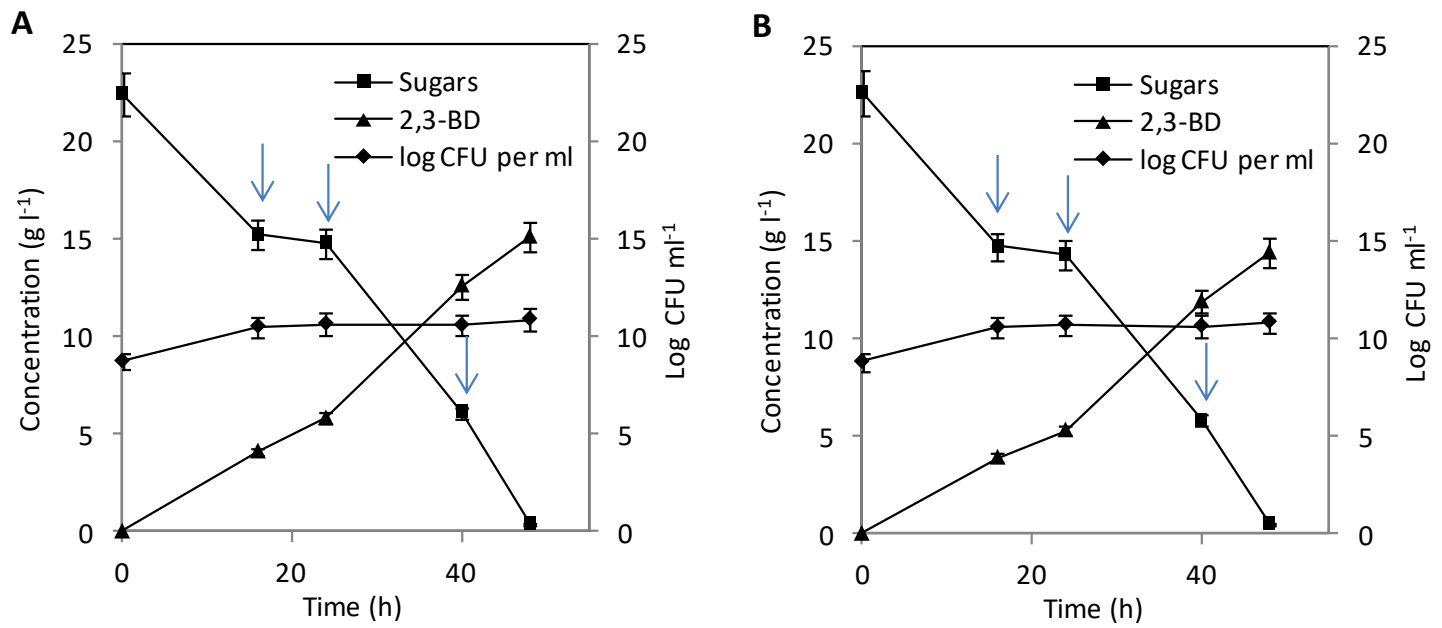

Figure 3. Fermentation of improved Raoultella planticola strains in fed-batch mode with OFMSW hydrolysate in flasks. Raoultella planticolla CECT 8158 (A) and Raoultella planticolla CECT 8159 (B).

\subsubsection{Optimization of 2,3-butanediol production in bioreactor}

The efficiency of 2,3-BD biosynthesis is affected by the choice of carbon source and parameters such aireation, $\mathrm{pH}$, temperature, amount of inoculums, and water activity. Other important factors are the culture protocols and bioreactor configurations (Ji et al., 2011). A first fed-batch assay was performed in 1.5 liter bioreactor with punctual additions of substrate using a 10 fold concentrated hydrolysate, increasing sugars concentration to avoid microorganisms inhibitions and culture dilution. Variables such as oxygen saturation and $\mathrm{pH}$ were established from previous 2,3-BD production studies (Fulgence et al., 2018; Bustamante et al., 2019). The feedings of substrate were added as follows: $5 \mathrm{ml}$ at $16 \mathrm{~h}, 10 \mathrm{ml}$ at $18 \mathrm{~h}, 30$ $\mathrm{ml}$ at $24 \mathrm{~h}$ and $50 \mathrm{ml}$ at $36 \mathrm{~h}$. In this case, a concentration of 23 grams per liter of 2,3-BD was reached and productivity decreased after 45 hours despite having carbon source remaining 
(Figure 4a). By contrast, $\mathrm{pH}$ decreased to 5.2 during fermentation and xylose was partially consumed while glucose was remaining in the culture, and up to 11 gram per liter of acetoin was produced as main by-product. Fermentation yield was 0.24 gram of 2,3-BD per gram of sugars, which is $49 \%$ of theoretical yield. Previous reports showed that $\mathrm{pH}$ is taken as a governing factor in microbial conversion processes being the trigger factor for 2,3-BD production, influencing the fermentation as an absolute value and by its spontaneous repeated $\mathrm{pH}$ fluctuations during the process (Petrov and Petrova, 2009).

Additional enhancement in 2,3-BD production (by significant increase of sugars utilization) was achieved using the method of "forced pH fluctuations" (Petrov and Petrova, 2010). Therefore, a second fermentation was performed in order to improve 2,3-BD yields with a similar fedbatch strategy but adding pulses of $\mathrm{NaOH} 5 \mathrm{M}$ between 0.5 and $2 \mathrm{ml}$ to maintain $\mathrm{pH}$ levels between 5.8 and 6.2 during fermentation. The substrate additions were adjusted as follows: $10 \mathrm{ml}$ at $16 \mathrm{~h}, 20 \mathrm{ml}$ at $24 \mathrm{~h}, 50 \mathrm{ml}$ at $36 \mathrm{~h}$ and $100 \mathrm{ml}$ at $48 \mathrm{~h}$; and alkali additions were made at the same time as substrate additions: $0.5 \mathrm{ml}, 1 \mathrm{ml}, 1.5 \mathrm{ml}$ and $2 \mathrm{ml}$, respectively. The $\mathrm{pH}$ of the culture medium is an important factor that must be controlled because for different microorganisms and substrates it is realted to the ability of bearing the osmotic pressure variations, thus $\mathrm{pH}$ strongly affects the distribution of metabolites in 2,3-BD fermentation (Fulgence et al., 2018). The results are shown in Figure 4b. 2,3-BD titer obtained following this fermentation strategy was 54 grams per liter with a yield of 0.5 gram 2,3-BD per gram of sugars ( $100 \%$ of theoretical yield), but it was realized by consecutive raisings of $\mathrm{pH}$ using definite $\Delta \mathrm{pH}$ value allowing multiple variations. In this case, when the $\mathrm{pH}$ is increased externally during OFMSW fermentation, $R$. planticola continues to acidify the medium while is producing 2,3-BD, and this behavior change from $\mathrm{pH} 5.2$, when productivity of 2,3-BD tends to decrease. The metabolic function of 2,3-BD has not been determined so far. However, it is tought that the production of 2,3-BD stimulated by lowered $\mathrm{pH}$ prevents intracellular acidification as it reduces the pool of acidic compounds in favor of neutral ones (Ji et al., 2011). The production of $2,3-\mathrm{BD}$ also contributes to the maintenance of an appropriate $\mathrm{NAD}^{+} / \mathrm{NADH}$ ratio in the cells, as it is involved in the regeneration of $\mathrm{NAD}^{+}$produced during glycolysis (Celińska and Grajek, 2009). Regarding metabolites produced during fermentation, of which excessive accumulation is a common problem in mixed-acid fermentation (Ji et al., 2009), Raoultella planticolla is able to produce 2,3-BD without 1,3-propanediol formation (Ripoll et al., 2016). At the same timeacetoin and ethanol were almost not detected while acetic acid and lactic acid titers tended to decrease at the end of the fermentation. Thus, the optimal conditions for maximal sugar consumption were defined, and the process was further scalable. 

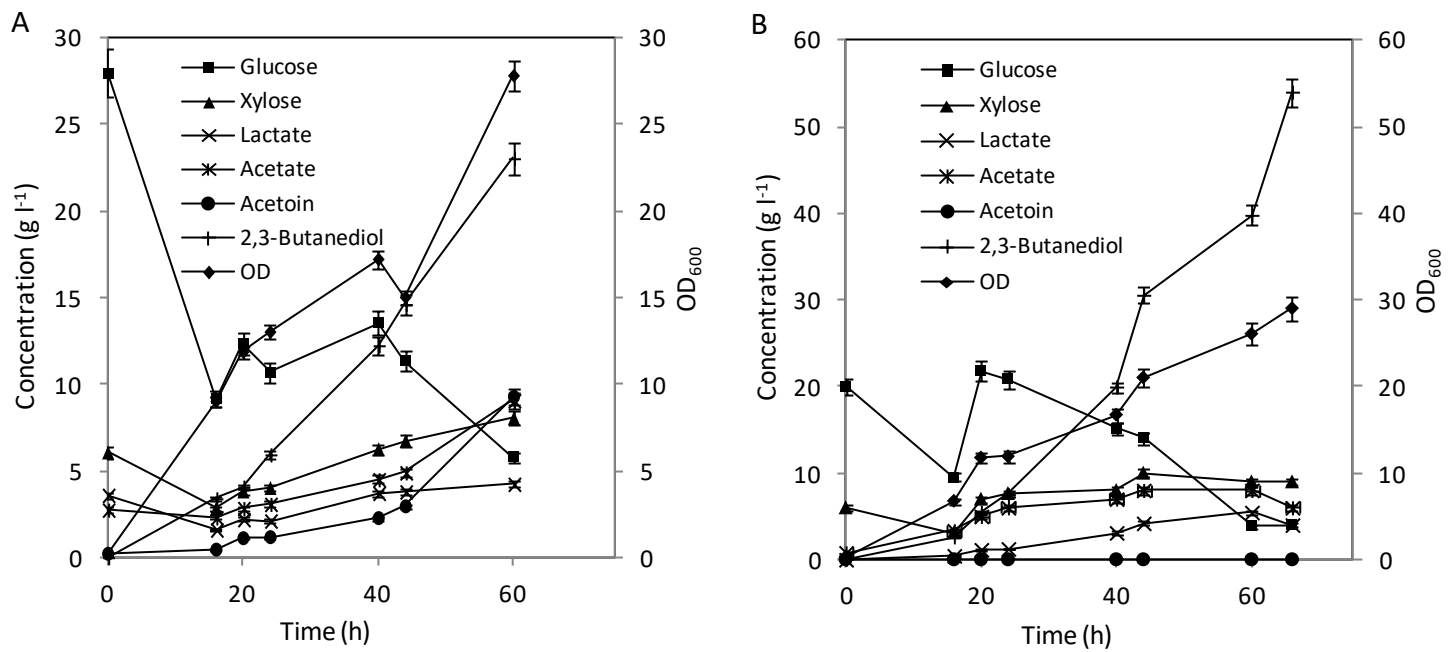

Figure 4. Fermentation of Raoultella planticola CECT 843 in fed-batch mode in 1.5 L bioreactor $0.5 \mathrm{~L}$ of initial work volume with feedings of 10 fold concentrated hydrolysate. A. Preliminary fed-batch approach. B. Optimization of fermentation with forced $\mathrm{pH}$ fluctuations between 5.8 and 6.2.

\subsubsection{Fermentation scale-up and mass balance for 2,3-BD production}

The hydrolysate used in this final fermentation had a sugar concentration of $25 \mathrm{gl}^{-1}$, which is less than the hydrolysates used in previous fermentations showing the heterogeneity of the OFMSW. The fermentation was carried out in 30 liter bioreactor with feedinds of substrate using a 10 fold concentrated hydrolysate and using the method of "forced pH fluctuations" from fermentation optimization. Results of the technical scale fermentation are shown in figure 5. The initial work volume was 10 liter with $80 \%\left(v v^{-1}\right)$ hydrolysate content and the fedbatch strategy was as follows: $0.2 \mathrm{I}$ at $16 \mathrm{~h}, 0.4 \mathrm{I}$ at $24 \mathrm{~h}, 1 \mathrm{I}$ at $36 \mathrm{~h}$ and $2 \mathrm{I}$ at $48 \mathrm{~h}$ with an additional feeding of $1.5 \mathrm{I}$ at $64 \mathrm{~h}$. Alkali additions were made at the same time as substrate additions: $10 \mathrm{ml}, 20 \mathrm{ml}, 30 \mathrm{ml}, 40$ and $40 \mathrm{ml}$, respectively. Sugar consumption and 2,3-BD formation follow the same trend as in lab scale assay until $48 \mathrm{~h}$ of fermentation when glucose is almost consumed due to less concentration of sugars in the initial hydrolysate. For this reason, changes in the metabolism of the strain seem to arise until the end of the fermentation producing organic acids as acetate, lactate and low amounts of succinate. Furthermore, there is formation of acetoin and ethanol and some accumulation of xylose, which also explains the decrease in productivity of 2,3-BD. In order to correct the behaviour of the strain and increase the 2,3-BD concentration in the culture, a last addition of substrate is made at $64 \mathrm{~h}$ and therefore the fermentation time increases and decreases the yield and the final productivity. Fermentation finished at $85 \mathrm{~h}$ with almost total glucose consumption and around 3 gram per liter of xylose remaining in the culture. Therefore, the final concentration of 
2,3-BD was 49.5 gram per liter with a yield of 0.45 gram of 2,3-BD per gram of sugars $(90 \%$ of theoretical yield) which is congruent with the values obtained in the lab scale fermentation even though productivity decreased from $0.8 \mathrm{~g} \mathrm{l}^{-1} \mathrm{~h}^{-1}$ at lab scale to $0.6 \mathrm{~g} \mathrm{l}^{-1} \mathrm{~h}^{-1}$ at technical scale.

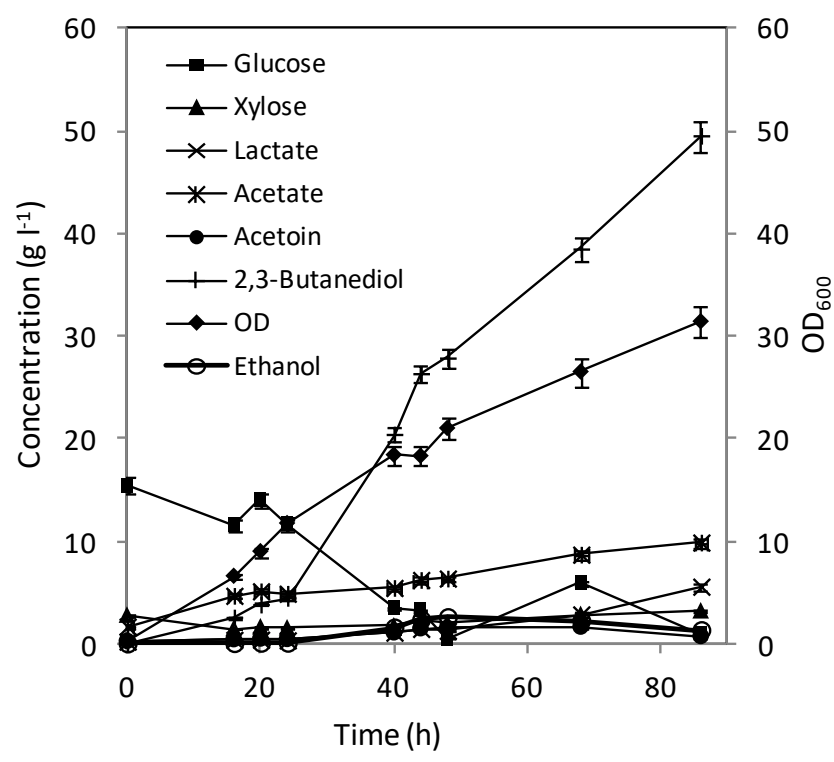

Figure 5. Fermentation of Raoultella planticola CECT 843 in fed-batch mode using 30 liter bioreactor with 10 liter of initial work volume with feedings of 10 fold concentrated hydrolysate and forced $\mathrm{pH}$ fluctuations between 5.8 and 6.2 .

Regarding mass balance, the hydrolysate were prepared at $20 \%$ solid loading, thus, every $\mathrm{kg}$ of hydrolysate contained $200 \mathrm{~g}$ of OFMSW. After hydrolysis, an average concentration of total sugars of $30 \mathrm{~g} \mathrm{l}^{-1}$ was achieved. Average density for the hydrolysate was $1.05 \mathrm{gl}^{-1}$; hence, every $\mathrm{kg}$ of hydrolysate contained $29 \mathrm{~g}$ of sugars. During the lab scale optimization and technical scale experiment average of the 2,3-BD yield from total sugars achieved was $0.5 \mathrm{~g} \mathrm{~g}^{-1}$. Therefore, approximately $15 \mathrm{~g}$ of 2,3-BD could be produced per $\mathrm{kg}$ of hydrolysate i.e. $200 \mathrm{~g}$ of dry OFMSW, wich corresponds to a yield of 0.08 gram of 2,3-BD per gram of dry OFMSW. There is no study available in literature about the production of 2,3-BD from real OFMSW samples. Nonetheles, the work from Liakou and colleagues (2018) using food waste can be used as reference. In processes with separate hydrolysis and fed-batch fermention the yields obtained were 0.15 and 0.04 gram of 2,3-BD per gram of dry fruits and vegetables, respectively. Thus, the yield obtained in this study using OFMSW obtained from composting treatment of MSW was suitable for demo-scale process development after hydrolysis optimisation. Table 2 summarizes studies of 2,3-BD production from sustainlable feedstocks by 
wild-type stains in fed-batch processes. The utilisation of OFMSW as feedstock should rely on the development of a biorefinery concept focusing on the extraction of value-added products prior to the production of 2,3-BD using the carbohydrate fraction. The biorefinery approach will create the profitability margin required for the reduction of the production cost of 2,3-BD. Koutinas and colleagues (2016) estimated that the minimum selling price of 2,3-BD is higher than $3 \$$ per kilogram based on fermentation efficiencies reported in the literature using molasses or sucrose as feedstocks. One of the biggest problems in 2,3-BD production is the development of a cost-competitive downstream separation process with low environmental impact.

Table 2. 2,3-BD production from sustainable feedstocks in fed-batch cultures by wild-type strains.

\begin{tabular}{|c|c|c|c|c|c|}
\hline Feedstock & Microorganism & Process & $\begin{array}{l}\text { Productivity } \\
\left(\mathrm{g}^{-1} \mathrm{~h}^{-1}\right)\end{array}$ & $\begin{array}{c}2,3-B D \\
\left(\mathrm{~g} \mathrm{I}^{-1}\right)\end{array}$ & References \\
\hline $\begin{array}{l}\text { Jerusalem artichoke } \\
\text { tubers powder }\end{array}$ & K. pneumoniae CICC10011 & SSF & 2.10 & 84.0 & Sun et al. (2009) \\
\hline $\begin{array}{l}\text { Jerusalem artichoke } \\
\text { tubers }\end{array}$ & K. pneumoniae CICC10011 & SHF & 1.09 & 60.9 & Sun et al. (2009) \\
\hline Glycerol & K. pneumoniae G31 & -- & 0.47 & 70.0 & $\begin{array}{l}\text { Petrov and Petrova } \\
\text { et al. (2010) }\end{array}$ \\
\hline $\begin{array}{l}\text { Jerusalem artichoke } \\
\text { stalk and tubers }\end{array}$ & K. pneumoniae CICC10011 & SSF & 0.99 & 67.4 & Li et al. (2010) \\
\hline Corncob & K. oxytoca ACCC 10370 & SHF & 0.56 & 35.7 & Cheng et al. (2010) \\
\hline Cassava powder & $\begin{array}{l}\text { E. clocacae ssp. dissolvens } \\
\text { SDM }\end{array}$ & SSF & 2.00 & 93.9 & Wang et al. (2012) \\
\hline Inulin hydrolysate & B. licheniformis ATCC 14580 & SSF & 3.43 & 103.0 & Li et al. (2014a) \\
\hline Corn stover & B. licheniformis $\mathrm{X}-10$ & SHF & 2.05 & 74.0 & Li et al. (2014b) \\
\hline Apple pomace & B. licheniformis NCIMB 8059 & SHF & 0.69 & 113.0 & $\begin{array}{l}\text { Białkowska et al., } \\
\text { (2015) }\end{array}$ \\
\hline Sugarcane molasses & B. subtilis TUL 322 & -- & 0.68 & 75.0 & $\begin{array}{l}\text { Białkowska et al., } \\
\text { (2016) }\end{array}$ \\
\hline Sugarcane molasses & $\begin{array}{l}\text { B. amyloliquefaciens TUL } \\
308\end{array}$ & -- & 0.43 & 60.0 & Sikora et al., (2016) \\
\hline Apple pomace & $\begin{array}{l}\text { B. amyloliquefaciens TUL } \\
308\end{array}$ & SHF & 0.16 & 34.2 & Sikora et al., (2016) \\
\hline Glycerol & R. ornithinolytica B6 & -- & 0.64 & 79.2 & Kim et al., (2017) \\
\hline Fruit waste & E. ludwigii FMCC 204 & -- & 0.41 & 50.1 & Liaku et al. (2018) \\
\hline Vegetable waste & E. ludwigii FMCC 204 & SHF & 0.39 & 17.6 & Liaku et al. (2018) \\
\hline OFMSW* & R. planticola CECT 286 & SHF & 0.80 & 50.0 & This work \\
\hline
\end{tabular}

* Selected throughout composting treatment.

SSF: Simultaneous saccharification and fermentation; SHF: Separate hydrolysis and fermentation.

\subsection{Conclusions}

The production of 2,3-BD was evaluated using hydrolysates of OFMSW samples selected from unfinished composting treatments. Raoultella planticola strains outperformed Bacillus licheniformis regarding tolerance and in flask cultures have shown yields of 0.5 gram of 2,3-BD 
per gram of sugars using OFMSW hydrolysates as culture medium at $75 \%\left(\mathrm{v} \mathrm{v}^{-1}\right)$ without any supplementation. Optimization and technical scale-up of the process were carried out with Raoultella planticola CECT 843 as model strain producing up to 50 grams per liter of 2,3-BD and reaching the theoretical yield using a fed-batch strategy by feedings of 10 fold concentrated hydrolysate and $\mathrm{pH}$ forced fluctuations, wich corresponds to a yield of 0.08 gram of 2,3-BD per gram of dry OFMSW. Further scale up of the process was carried out to validate the process up to 3000 liters bioreactors (Patent WO2019180220A1) but the results obtained are outside the scope of this work and the details of the process at demo scale are confidential. This process is an example of sustainable development in the production of platform chemicals for the new bioeconomy-era.

\section{References}

Białkowska, A.M. (2016) Strategies for efficient and economical 2, 3-butanediol production: new trends in this field. World J Microbiol Biotechnol 32: 200.

Białkowska, A.M., Gromek, E., Krysiak, J., Sikora, B., Kalinowska, H., Krzepkowska, M.J., Kubik, C., Lang, S., Schutt, F., Turkiewicz, M (2015) Application of enzymatic apple pomace hydrolysate to production of 2,3-butanediol by alkaliphilic Bacillus licheniformis NCIMB 8059. J Ind Microbiol Biotechnol 42: 16091621.

Białkowska, A. M., Jędrzejczak-Krzepkowska, M., Gromek, E., Krysiak, J., Sikora, B., Kalinowska, H., Celina, K., Schütt, F., Turkiewicz, M. (2016). Effects of genetic modifications and fermentation conditions on 2, 3-butanediol production by alkaliphilic Bacillus subtilis. Applied microbiology and biotechnology 100(6): 2663-2676.

Bustamante, D., Segarra, S., Montesinos, A., Tortajada, M., Ramón, D., Rojas, A. (2019) Improved Raoultella planticola strains for the production of 2,3-butanediol from glicerol. Fermentation 5(1):11.

Celińska, E., Grajek, W. (2009) Biotechnological production of 2,3-butanediol-current state and prospects. Biotechnol Adv 27: 715-725.

Cheng, K.K., Liu, Q., Zhang, J.A., Li, J.P., Xu, J.M., Wang, G.H. (2010) Improved 2,3-butanediol production from corncob acid hydrolysate by fed-batch fermentation using Klebsiella oxytoca. Process Biochem 45: 613-616.

Díaz, A.I., Laca, A., Laca, A., Díaz, M. (2017) Treatment of supermarket vegetable wastes to be used as alternative substrates in bioprocesses. Waste Manag 57: 59-66 
Drancourt, M., Bollet, C., Carta, A., Rousselier, P. (2001) Phylogenetic analyses of Klebsiella species delineate Klebsiella and Raoultella gen. nov. with description of Raoultella ornithinolytica comb. nov. Raoultella terrigena comb. nov., and Raoultella planticola comb. nov. Int J Syst Evol Microbiol 51: 92532.

Fulgence, S., Yan, X., Cong, R. (2018) Current advances in the production of 2,3-butanediolby microbial fermentation. J Acad Ind Res 6: 188-197.

Fava, F., Totaro, G., Diels, L., Reis, M., Duarte, J., Carioca, O.B., Poggio-Varaldo, H.M., Ferreira, B.S. (2015) Biowaste biorefinery in Europe: opportunities and research and development needs. $N$ Biotechnol 32(1): 100-108.

Gao, J., Xu, H., Li, Q.J., Feng, X.H., Li, S. (2010) Optimization of medium for one-step fermentation of inulin extract from Jerusalem artichoke tubers using Paenibacillus polymyxa ZJ-9 to produce R, R-23butanediol. Bioresour Technol 101: 7087-7093.

Harvey, B.G., Merriman, W.W., Quintana, R.L. (2016) Renewable Gasoline, Solvents, and Fuel Additives from 2,3-Butanediol. ChemSusChem 9(14): 1814-1819.

Ji, X.J., Huang, H., Zhu, J.G., Ren, L.J., Nie, Z.K., Du, J., Li, S. (2009) Engineering Klebsiella oxytoca for efficient 2,3-butanediol production through insertional inactivation of acetaldehyde dehydrogenase gene. Appl Microbiol Biotechnol 85(6): 1751-1758.

Ji, X.J., Huang, H., Ouyang, P.K. (2011) Microbial 2,3-butanediol production: A state-of-the-art review. Biotechnol Adv 29: 351-364.

Jiayang, Q.I.N., Zijun, X.I.A.O., Cuiqing, M.A., Nengzhong, X.I.E., Peihai, L.I.U., Ping, X.U. (2006) Production of 2,3-butanediol by Klebsiella Pneumoniae using glucose and ammonium phosphate. Chin J Chem Eng 14(1): 132-136.

Jensen, J.W., Felby, C., Jørgensen, H. (2011) Cellulase hydrolysis of unsorted MSW. Appl Biochem Biotechnol 165(7-8): 1799-811.

Jurchescu, I.M., Hamann, J., Zhou, X., Ortmann, T., Kuenz, A., Prüße, U., Lang, S. (2013) Enhanced 2,3butanediol production in fed-batch cultures of free and immobilized Bacillus licheniformis DSM 8785. Appl Microbiol Biotechnol 97: 6715-6723.

Kim, T., Cho, S., Lee, S.M., Woo, H.M., Lee, J., Um, Y., Seo, J.H. (2016). High production of 2, 3-butanediol (2,3-BD) by Raoultella ornithinolytica B6 via optimizing fermentation conditions and overexpressing 2,3BD synthesis genes. PloS one 11(10): e0165076.

Kim, T., Cho, S., Woo, H. M., Lee, S. M., Lee, J., Um, Y., \& Seo, J. H. (2017). High production of 2, 3- 
butanediol from glycerol without 1, 3-propanediol formation by Raoultella ornithinolytica B6. Appl microbiol biotechnol 101(7): 2821-2830.

Koutinas, A.A., Yepez, B., Kopsahelis, N., Freire, D.M., de Castro, A.M., Papanikolaou, S., and Kookos, I.K. (2016) Techno-economic evaluation of a complete bioprocess for 2,3-butanediol production from renewable resources. Bioresour Technol 204: 55-64.

Li, D., Dai, J. Y., \& Xiu, Z. L. (2010). A novel strategy for integrated utilization of Jerusalem artichoke stalk and tuber for production of 2, 3-butanediol by Klebsiella pneumoniae. Bioresour Technol 101(21): 83428347.

Li, L., Chen, C., Li, K., Wang, Y., Gao, C., Ma, C., \& Xu, P. (2014a). Efficient simultaneous saccharification and fermentation of inulin to 2, 3-butanediol by thermophilic Bacillus licheniformis ATCC 14580. Appl Environ Microbiol 80(20): 6458-6464.

Li, L., Li, K., Wang, K., Chen, C., Gao, C., Ma, C., \& Xu, P. (2014). Efficient production of 2, 3-butanediol from corn stover hydrolysate by using a thermophilic Bacillus licheniformis strain. Bioresour technol 170: 256-261.

Liakou, V., Pateraki, C., Palaiogeorgou, A.M., Kopsahelis, N., de Castro, A.M., Freire, D.M.G., Nychas, G.J.E., Papanikolaou, S., Koutinas, A. (2018) Valorisation of fruit and vegetable waste from open markts for the production of 2,3-butanediol. Food Bioprod Process 108: 27-36.

Matsakas, L., Gao, Q., Jansson, S., Rova, U., Christakopoulos, P. (2017) Green conversion of municipal solid wastes into fuels and chemicals. Electron J Biotechnol 26: 69-83.

Mazumdar, S., Lee, J., Oh, M.K. (2013) Microbial production of 2,3-butanediol from seaweed hydrolysate using metabolically engineered Escherichia coli. Bioresour Technol 136:329-336.

Nakashimada, Y., Kanai, K. and Nishio, N. (1998) Optimization of dilution rate, pH and oxygen supply on optical purity of 2,3-butanediol produced by Paenibacillus polymyxa in chemostat culture. Biotechnol Lett 20: 1133-8.

Nguyen, N.T.T., Matei-Rutkovska, F., Huchede, M., Jaillardon, K., Qingyi, G., Michel, C., and Millet, J.M.M. (2018) Production of 1, 3-butadiene in one step catalytic dehydration of 2, 3-butanediol. Catal Today 323: 62-68.

Pagliano, G., Ventorino, V., Panico, A., Pepe, O. (2017) Integrated systems for biopolymers and bioenergy production from organic waste and by-products: a review of microbial processes. Biotechnol Biofuels 10: 113.

Parate, R.D., Rode, C.V., Dharne, M.S. (2018) 2,3-Butanediol production from biodiesel derived glycerol. 
Curr Environ Eng 5(1): 4-12.

Petrov, K., Petrova, P. (2009) High production of 2,3-butanediol from glycerol by Klebsiella pneumoniae G31. Appl Microbiol Biotechnol 84: 659-665.

Petrov, K., Petrova, P. (2010) Enhanced production of 2,3-butanediol from glycerol by forced pH fluctuations. Appl Microbiol Biotechnol 87: 943-949.

Rebecchi, S., Zanaroli, G., Fava, F. (2016) 2,3-Butanodiol production from biowastes with Bacillus Licheniformis: a preliminary study. Chem Eng Trans 49: 379-384.

Ripoll, V., de Vicente, G., Morán, B., Rojas, A., Segarra, S., Montesinos, A., Tortajada, M., Ramón, D., Ladero, M., Santons, V.E. (2016) Novel biocatalysts for glycerol conversion into 2,3-butanediol. Process Biochemestry 51: 740-748.

Sikora, B., Kubik, C., Kalinowska, H., Gromek, E., Białkowska, A., Krzepkowska, M.J., Schutt, F., Turkiewicz, M. (2016) Applications of byproducts from food processing for production of 2,3-butanediol using Bacillus amyloliquefaciens TUL 308. Prep Biochem Biotechnol 46: 610-619.

Sluiter, A., Hames, B., Ruiz, R., Scarlata, C., Sluiter, J., Templeton, D., Crocker, D., (2008a) issue date, 4/25/2008 In: Sluiter, A. (Ed.), Determination of structural carbohydrates and lignin in biomass laboratory analytical procedure (LAP). National Renewable Energy Laboratory, Golden, Colo.

Sluiter, A., Hames, B., Ruiz, R., Scarlata, C., Sluiter, J., Templeton, D., (2006) Determination of Sugars, Byproducts, and Degradation Products in Liquid Fraction Process Samples. National Renewable Energy Laboratory, Golden.

Sluiter, A., Ruiz, R., Scarlata, C., Sluiter, J., Templeton, D., (2008b) issue date, 7/17/2005 In: Sluiter, A. (Ed.), Determination of extractives in biomass laboratory analytical procedure (LAP). National Renewable Energy Laboratory, Golden, Colo.

Sun L.H., Wang, X.D, Dai, J.Y., Xiu, Z.L. (2009) Microbial production of 2,3-butanediol from Jerusalem artichoke tubers by Klebsiella pneumoniae. Appl Microbiol Biotechnol 82: 847-852.

Tonini, D., Martinez-Sanchez, V., Astrup, T.F. (2013) Material resources, energy, and nutrient recovery from waste: are waste refineries the solution for the future? Environ Sci Technol 47: 8962-8969.

Vea, E.B., Romeo, D., Thomsen, M. (2018) Biowaste valorisation in a future circular bioeconomy. Procedia CIRP 69: 591-596.

Wang, A., Xu, Y., Ma, C., Gao, C., Li, L., Wang, Y., Tao, F. and Xu, P. (2012). Efficient 2, 3-butanediol production from cassava powder by a crop-biomass-utilizer, Enterobacter cloacae subsp. dissolvens SDM. PLoS One 7(7): e40442. 
Wong, C.L., Huang, C.C., Luc, W.B., Chen, W.M., Chang, J.S. (2012) Producing 2,3-butanediol from agricultural waste using an indigenous Klebsiella sp. Zmd30 strain. Biochem Eng J 69: 32-40.

Yang, Z., Zhang, Z. (2018) Recent advances on production of 2,3-butanediol using engineered microbes. Biotechnol Adv 37(4): 569-578 


\section{CHAPTER V}

Production of D-lactic acid by the fermentation of orange peel waste hydrolysate by lactic acid bacteria 


\subsection{Background and aim}

Lactic acid is an important chemical and has attracted a great attention due its widespread applications in the food, pharmaceutical, cosmetic, and textile industries. Polylactic acid (PLA) is a biodegradable polymer with great potential in replacing petrochemical polymers and therefore, L-and D-lactic acids are prominent monomers of the bioplastic industry (Esteban and Ladero 2018). The morphological, mechanical and thermal properties of the polymer are determined by the presence of different amounts of L- and D-lactic acid monomers or oligomers (John et al. 2009; Abdel-Rahman et al. 2011; Klotz et al. 2016; Wang et al.2015; Singhvi et al.2018). Microbial production of optically pure lactic acid has extensively been studied because chemically synthesized lactic acid is a racemic mixture (John et al. 2007). In fact, the optimization of operation conditions is very effective to achieve high selectivity to the isomer of interest (Tashiro et al.2011). Although the L-isomer has been studied in detail, information on biosynthesis of D-lactic acid (D-LA) is still limited (Zhang and Vadlani 2013; Wang et al., 2015).

PLA market demand accounts for $11.4 \%$ of total bioplastic production worldwide, approximately $18 \times 10^{4}$ metric tons per year and the PLA demand is estimated to grow by $28 \%$ per year until 2025. However, production costs of PLA are still high, mainly due to expensive fermentation media components. To overcome this problem, several residues have been employed as raw material (Tanaka et al., 2006; John et al. 2007; Abdel-Rahman et al. 2011; Abdel-Rahman et al. 2013; Wang et al.2015; Zhang et al. 2016). Production of D-LA from liquid pineapple wastes (Idris and Suzana 2006), date juice (Choi et al.2014), corn stover (Hu et al. 2015), hardwood pulp hydrolysate (Hama et al. 2015) and brown rice (Okano et al. 2017) has been studied. Valorising food waste to useful products such as D-LA is a good alternative (Van Dyk et al. 2013; Girotto et al. 2015; Esteban and Ladero 2018). In particular, orange peel and pulp waste $(\mathrm{OPW})$ can be used to produce D-LA after adequate pre-treatment processes (Rezzadori et al. 2012; Negro et al. 2016; de la Torre et al. 2017).

Orange waste is the most abundant citrus waste with up to 50 million metric tons of oranges consumed every year (Choi et al., 2015). This huge amount of waste accounts for $45 \%-60 \%$ of the total fruit weight, and therefore, a lot of potential applications have been studied for their valorization to date (Rafiq et al., 2016). The main application of this residue is as an ingredient for cattle feed or as pelletized dry solid fuel, but its processing results in highly polluted wastewater (Martín et al., 2010). The use of citrus waste to produce compounds of high added 
value, essential oils, fertilizer, pectin, industrial enzymes, ethanol and absorbents has recently been described (Martín et al., 2010; Oberoi et al., 2010; Pourbafrani et al., 2010; Lugo-Lugo et al., 2012; Choi et al., 2015; Negro et al., 2016; Rafiq et al., 2016). In addition, orange waste present low levels of lignin and a large amount of sugars (Oberoi et al., 2010), which make it an ideal substrate for fermentation processes after the implementation of the required pretreatment and enzymatic hydrolysis stages.

Lactic acid is produced in high amounts by lactic acid bacteria (LAB) which cando so in a homofermentative way employing the Embden-Meyerhof pathway where lactic acid is the only acid produced, or by the heterofermentative way following the phosphogluconate and phosphoketolase pathway where lactic acid is one of the products and yields of $0.5 \mathrm{~g} \mathrm{~g}^{-1}$ of hexose. LABs produce either one or the two forms of lactate (Abdel-Rahman et al., 2013; Mazzoli et al., 2014; Eiteman and Ramalingam 2015; Klotz et al. 2016). Lactobacillus delbrueckii ssp. delbrueckii has been reported as a homofermentative producer of D-LA using several agroindustrial residues (Zhang and Vadlani, 2013). This bacterium yields 90\% D-LA from sugarcane molasses, 95\% D-LA from sugarcane juice, 88\% D-LA from sugar beet juice (Calabia and Tokiwa, 2007) and 88\% D-LA from orange peel waste (OPW) (de la Torre et al., 2018). Moreover, the species Lactobacillus delbrueckii subsp. bulgaricus has been used in the dairy industry to transform milk into yogurt and some strains are able to produce highly pure D-LA (Benthin and Villadsen, 1995a). Therefore, lactose and whey have been widely studied as raw materials for lactic acid production (Benthin and Villadsen, 1995b; Adamberg et al., 2003; Aghababaie et al., 2014) even cloning the D-lactate dehydrogenase gene in Escherichia coli (Bernard et al., 1991). Other studies include wheat flour, molasses, sorghum and lignocellulosic hydrolysates as feedstocks for the production of lactic acid by Lactobacillus delbrueckii subsp. bulgaricus, especially for L-LA isomer production (Hofvendal et al., 2000; Abdel-Rahman et al., 2013). This fact means that some strains of Lactobacillus delbrueckii subsp. bulgaricus could be potential candidates for D-LA production from sustainable feedstocks.

The aim of this work was to find LAB strains of producing D-LA with high yield and optical purity from OPW as raw material to contribute in the development of biowaste-refineries. For this purpose, several Lactobacillus delbrueckii ssp. bulgaricus strains were evaluated in comparison to the reference strain Lactobacillus delbrueckii ssp. delbrueckii CECT 286 which has been reported as a high yield producer of D-LA from biowaste and OPW hydrolysate in particular. 


\subsection{Materials and Methods}

\subsubsection{Bacterial strains, media and growth conditions}

The bacterial strains employed in this study are listed in Table 1 and Lactobacillus delbrueckii ssp. delbrueckii CECT 286 was used as reference strain. The selected strains were purchased from the Spanish Type Culture Collection (CECT). After being recevied, they were recovered in tubes containing MRS medium and stored in $20 \%$ glycerol glycerol at $-80^{\circ} \mathrm{C}$ for long-term preservation. Precultures were prepared in tubes containing MRS medium with a small headspace and incubated overnight at $37^{\circ} \mathrm{C}$ and static micro-aerobic conditions.

Table 1. Lactic acid bateria (LAB) strains selected for D-lactic acid production screening.

\begin{tabular}{ll}
\hline Microorganism & Strain \\
\hline L. delbrueckii ssp. bulgaricus & CECT 4005 \\
L. delbrueckii ssp. bulgaricus & CECT 4006 \\
L. delbrueckii ssp. bulgaricus & CECT 5035 \\
L. delbrueckii ssp. bulgaricus & CECT 5036 \\
L. delbrueckii ssp. bulgaricus & CECT 5037 \\
L. delbrueckii ssp. bulgaricus & CECT 5038 \\
\hline
\end{tabular}

Screening of $L A B$ strains was performed in $15 \mathrm{ml}$ tubes at $37^{\circ} \mathrm{C}$ and using a medium with sugars resembling OPW hydrolysate as follows: MRS broth plus glucose $30 \mathrm{~g} \mathrm{I}^{-1}$, fructose $20 \mathrm{~g} \mathrm{I}^{-1}$, galactose $5 \mathrm{~g} \mathrm{l}^{-1}$ and arabinose $6 \mathrm{~g} \mathrm{l}^{-1}$. Cultures were inoculated in duplicate with $5 \%\left(\mathrm{v} \mathrm{v}^{-1}\right)$ of preculture and were incubated in orbital shaker at $200 \mathrm{rpm}$. Aerobic and micro-aerobic conditions were tested at $\mathrm{pH} 6.2$ for 40 hours.

\subsubsection{OPW hydrolysate tolerance assays}

Tolerance assays were performed in triplicate using selected strains and preparing a multi-well plate with $200 \mu \mathrm{l}$ of MRS with OPW hydrolysate diluted at $50 \%, 85 \%$ and $100 \%\left(v^{-1}\right.$ ) as culture medium for each condition in triplicate. Precultures were prepared in MRS and inoculated at $10 \%$ of total volume. A microplate incubator spectrophotometer was used with temperature set at $37^{\circ} \mathrm{C}$ for 45 hours. The plate was shaken every hour for 5 seconds before each $\mathrm{OD}_{600}$ measurement to obtain the growth curves of the strains. 


\subsubsection{Fermentation assays}

Strains were cultured in $50 \mathrm{ml}$ tubes containing MRS with 85\% $\left(\mathrm{v} \mathrm{v}^{-1}\right)$ OPW hydrolysate at $\mathrm{pH}$ $6.2,37^{\circ} \mathrm{C}$ and $45^{\circ} \mathrm{C}$ in micro-aerobic conditions. An additional assay was done by adjusting $\mathrm{pH}$ at 5.8 each 24 hours with $\mathrm{NaOH} 5 \mathrm{M}$. All runs started by inoculating $15 \%\left(\mathrm{v} \mathrm{v}^{-1}\right)$ of preculture and then incubated in an orbital shaker at 200 rpm for 120 hours.

The experiments in the bioreactor setup were performed in 1.5L Applikon ${ }^{\circledast}$ in batch mode with OPW hydrolysate at $85 \%\left(\mathrm{v} \mathrm{v}^{-1}\right)$ with MRS and $5 \mathrm{gl}^{-1}$ meat extract as additional nitrogen source. The OPW hydrolysate was sterilized using sterile glass fiber and cellulose acetate membrane filters with $0.2 \mu \mathrm{m}$ of pore size, and then added to the bioreactor. Before the inoculum addition, the anaerobic atmosphere was obtained by stripping the oxygen off with a nitrogen stream. The experimental conditions were set up at $37^{\circ} \mathrm{C}, 200 \mathrm{rpm}$, and $\mathrm{pH}$ of 5.8 , adding $\mathrm{NaOH} 5 \mathrm{M}$ or $\mathrm{HCl} 2 \mathrm{M}$ for $\mathrm{pH}$ control during fermentation.

\subsubsection{OPW pretreatments}

The substrate used in this study was OPW obtained from juice elaboration. These residues were blade-milled to a final particle diameter of around $5 \mathrm{~mm}$ and then, samples were subsequently stored in a freezer at $-20^{\circ} \mathrm{C}$ until use. The characterization of the raw material was performed according to the NREL procedures for determination of structural carbohydrates and free sugars, in addition to extractives (Sluiter et al., 2006, 2008ab), while moisture was assessed by using an infrared drying balance at temperatures between 70 and $90^{\circ} \mathrm{C}$ untill constant weight. The results obtained by applying the NREL methodology are compiled in Table 2.

Table 2. OPW composition analysis according to NREL protocols.

\begin{tabular}{lc}
\hline Component & \% Dry weight $\left(\mathrm{w} \mathrm{w} \mathrm{w}^{-1}\right)$ \\
\hline Total solids & $19.2 \pm 0.5$ \\
Ash & $3.9 \pm 0.2$ \\
Fats & n.d. \\
Water extractives & $37.5 \pm 0.4$ \\
Free sugars & $36.4 \pm 0.6$ \\
Glucan & $19.1 \pm 0.1$ \\
Hemicellulose & $14.8 \pm 0.2$ \\
Lignin & $6.2 \pm 0.5$ \\
Pectin & $17.9 \pm 1.5$ \\
\hline
\end{tabular}

For D-LA production assays, OPW was milled down to 1-2 $\mathrm{mm}$ particle size and hydrolysis was 
carried out at $10 \%\left(\mathrm{w} \mathrm{w}^{-1}\right)$ of dry solid, $50^{\circ} \mathrm{C}, 300 \mathrm{rpm}$ and initial $\mathrm{pH}$ of 5.2 using enzyme cocktails with cellulases, $\beta$-glucosidase, xylanase, $\beta$-xylosidase, pectinase, and auxiliary activities (Celluclast 1.5 I, Novozym 188, Pectinex Ultra SP-L gifted by Novozymes) as described by de la Torre and colleagues (2017).

\subsubsection{Analytical procedures}

The content of sugars and organic acids was determined by HPLC liquid chromatography (2695 HPLC with a refractive Index Detector 2414; Waters, Cerdanyola del Vallés, Spain) using a Rezex ROA Organic acid column, with $\mathrm{H}_{2} \mathrm{SO}_{4}$ at $2.5 \mathrm{mM}$ and $0.5 \mathrm{ml} \mathrm{min}{ }^{-1}$ flow. The optical purity of D-LA was determined by HPLC (Agilent Technologies 1100 Series, Waldbronn, Germany) using a DAD detector, a Chirex 3126 (D)-penicillamine (250×4.6; Phenomenex) column working at room temperature, and a $\mathrm{CuSO}_{4} 1 \mathrm{mM}$ solution as mobile phase flowing at $1.2 \mathrm{ml} \mathrm{min}^{-1}$.

\subsection{Results and discussion}

\subsubsection{Screening of $L A B$ strains for D-LA production}

Lactic acid production was tested in $15 \mathrm{ml}$ tubes containing $3 \mathrm{ml}$ of culture resembling OPW hydrolysate for aerobic conditions and $14 \mathrm{ml}$ of culture for micro-aerobic conditions to compare the behavior of the different LAB strains. Results are shown in Figure 1. Lactobacillus delbrueckii ssp. bulgaricus CECT 4005 and CECT 5038 did not produce a significant amount of lactic acid while $L$. delbrueckii ssp. bulgaricus CECT 5036 produced up to $14 \mathrm{~g} \mathrm{I}^{-1}$ of lactic acid racemic mixture in aerobic and micro-aerobic conditions. Furthermore, three strains, $L$. delbrueckii ssp. bulgaricus CECT 4006, CECT 5035 and CECT 5037 transformed sugars into lactic acid in micro-aerobic condition with D-LA enantiomeric excess in the same way as $L$. delbrueckii ssp. delbrueckii CECT 286. Those strains produced around $15 \mathrm{gl}^{-1}$ of lactic acid with around 75\% (e.e.) of D-LA while L. delbrueckii ssp. delbrueckii CECT 286 reached 92\% (e.e.) of D-LA. Therefore, those three strains were selected to study D-LA production from OPW hydrolysate in micro-aerobic conditions. Previous reports showed that lactose rather than glucose markedly increases the growth rate of L. delbrueckii ssp. bulgaricus strains (Benthin and Villadsen, 1995a; 1995b). Therefore, transport systems of sugars other than lactose are likely to vary among these strains and hence, some strains, such as L. delbrueckii ssp. bulgaricus CECT 4005 and CECT 5038, appear to have difficulties to assimilate the sugars tested 
in this work. Moreover, strains such as L. delbrueckii ssp. bulgaricus CECT 5035 and CECT 5037 show low yield in assays at aerobic conditions in the same way as L. delbrueckii ssp. delbrueckii CECT 286. It is known that during growth, toxic oxygen derivatives are produced for LAB strains in aerobic conditions, but the enzymes required to eliminate them seems not to be expressed in some L. delbrueckii ssp. bulgaricus strains (Archibald and Fridovich, 1981). Reducing agents may provide protection against toxic products, particularly if growth conditions are not strictly anaerobic. However, with exception of L. delbrueckii ssp. bulgaricus CECT 5036, the other strains showed higher selectivity to D-LA than L. delbrueckii ssp. delbrueckii CECT 286 in aerobic conditions and as mentioned above, L. delbrueckii ssp. bulgaricus CECT 5036 have similar results at aerobic and micro-anaerobic conditions but produced racemic mixture in both cases. L. delbrueckii ssp. bulgaricus CECT 4005 appears to prefer aerobic conditions but yields are still low.
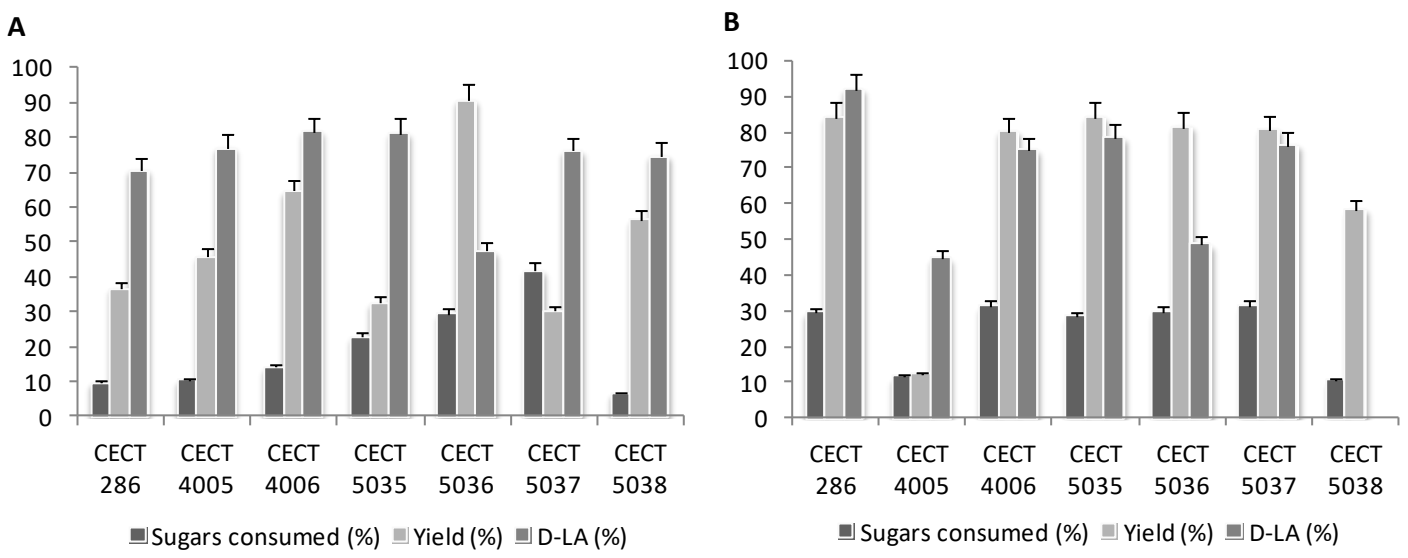

Figure 1. D-LA production in $15 \mathrm{ml}$ tubes with MRS medium containing sugars resembling OPW hydrolysate using LAB strains selected for screening. A. Aerobic conditions. B. Micro-aerobic conditions.

\subsubsection{Use of OPW hydrolysate for D-LA production by selected strains}

The OPW hydrolysates were prepared following the methodology described in Section 5.2.4 and developed by de la Torre and colleagues (2017) obtaining a glucose yield around 60\% and total sugar concentration above $50 \mathrm{~g} \mathrm{I}^{-1}$. Therefore, OPW is a good source of several monosaccharides but also have essential oils rich in limonene and containing terpenes and phenolics with some antimicrobial activity (Negro et al., 2016). The tolerance of the strains to the substrate was tested with different concentrations of OPW hydrolysate ranging from $50 \%$ to $100 \%\left(v^{-1}\right)$ diluted with MRS broth. Growth monitoring was performed in a micro-plate incubator for 48 hours (Figure 2). Microorganisms grew up well at $50 \%\left(v v^{-1}\right)$ hydrolysate 
content, but the strain L. delbrueckii ss.p delbrueckii CECT 286 tolerated the hydrolysate and was able to grow even when hydrolysate content was $100 \%\left(\mathrm{v} \mathrm{v}^{-1}\right)$. Lactobacillus delbrueckii ssp. bulgaricus CECT 4006 appears to be more sensitive to OPW hydrolysate while $L$. delbrueckii ssp. bulgaricus CECT 5037 was able to grow up at any OPW concentration; however, the higher the hydrolysate concentration, the higher the lag phase and the lower the growth. Differences lied on the performance of the strains, which is slightly lower when using OPW hydrolysates, probably due to the presence of essential oil components, either terpenes or phenolics. However, Lactobacilli are able to withstand relatively high concentrations of citrus extracts (Bevilacqua et al. 2010).
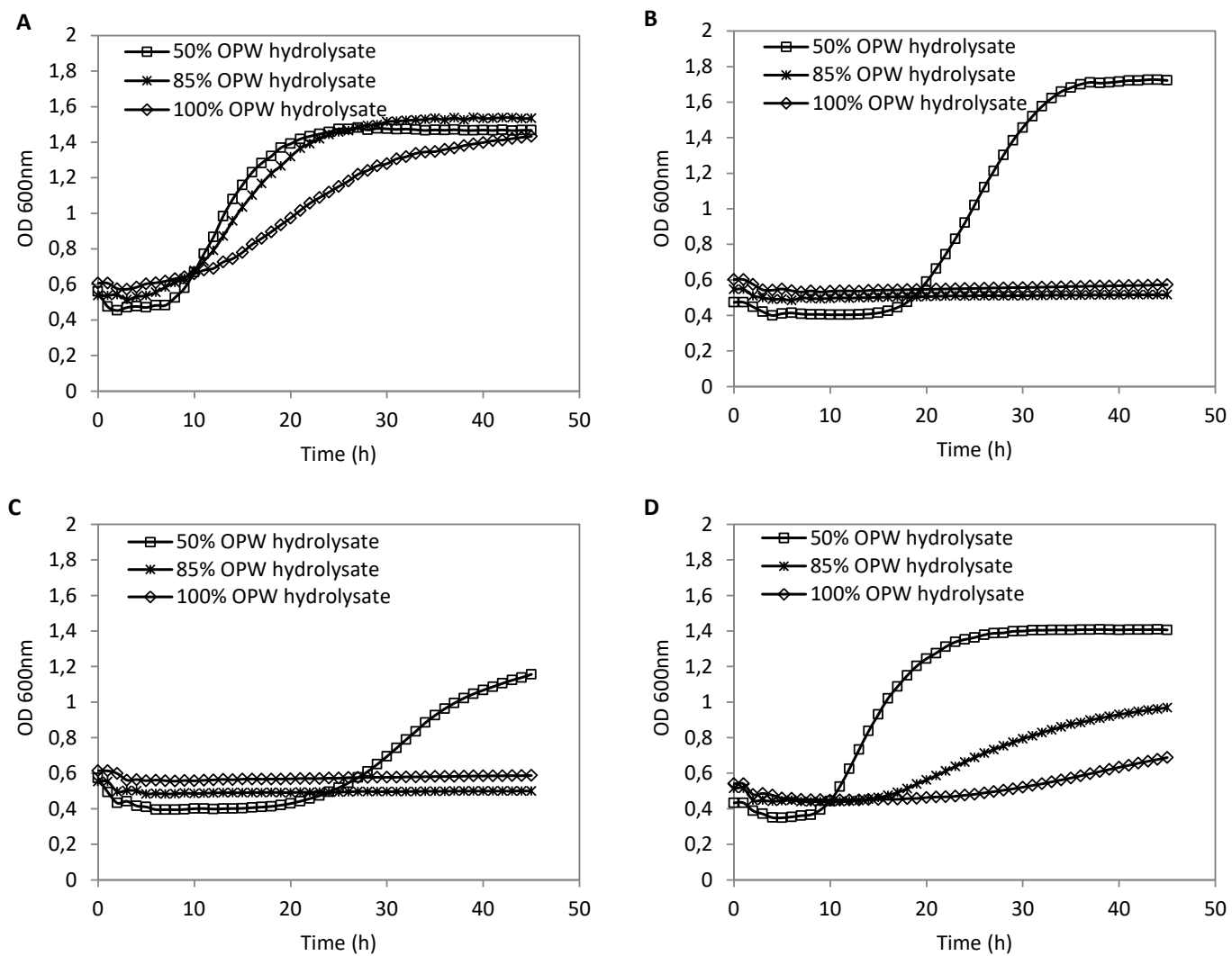

Figure 2. Growth curves for tolerance assays to OPW hydrolysate in micro-plates and micro-arebic conditions. A. Lactobacillus delbrueckii ssp. delbreckii CECT 286. B. Lactobacillus delbrueckii ssp. bulgaricus CECT 4006. C. Lactobacillus delbrueckii ssp. bulgaricus CECT 5035. D. Lactobacillus delbrueckii ssp. bulgaricus CECT 5037. The results were obtained as the average of three replicates and standard deviation was lower than $0.5 \%$.

Concerning the nutritional requirements, previous studies showed that niacin, calcium pantothenate, riboflavin, and vitamin B12 were essential for the growth of $L$. delbrueckii ssp. bulgaricus, and that folic acid, pyridoxal, and $\mathrm{CaCl}_{2}$ were important for efficient growth 
(Grobben et al., 1998; Chervaux et al., 2000). There could be discrepancies due to differences in medium composition or to strain-specific requirements as in the case of $L$. delbrueckii ssp. bulgaricus CECT 5037, which not only seems to tolerate hydrolysate, but also seems to grow with less strict nutritional requirements. Although L. delbrueckii ssp. delbueckii CECT 286 and L. delbrueckii ssp. bulgaricus CECT 5037 have shown highest robustness cultured in OPW hydrolysate, the next assays were performed using the four selected strains and inoculating the cells recovered from $15 \%\left(v v^{-1}\right)$ of preculture with respect to the volume of culture at $85 \%$ $\left(v v^{-1}\right)$ OPW hydrolysate diluted with MRS medium and micro-aerobic conditions. The inoculum amount was increased to compare the performance of the selected strains with the maximum concentration of OPW hydrolysate during the preliminary fermentation trials.

The optimal growth temperature for Lactobacilli ranges from 30 to $40^{\circ} \mathrm{C}$, although some thermophilic strains grow well and have highly activated metabolism at temperatures around $45^{\circ} \mathrm{C}$ (Adamberg et al., 2003). The four Lactobacillus strains selected were cultured at $37^{\circ} \mathrm{C}$ and $45^{\circ} \mathrm{C}$ during 120 hours to test their activity at conditions as close as possible to those of hydrolysis stage and, therefore, to evaluate if the hydrolysis and fermentation stages could be done simultaneously (SSF) as a preliminary result for the future optimization and scale-up of the process. In general, the SSF process offers better yields because it avoids product inhibition and results in higher productivity (Tanaka et al., 2006). Aghababaie and colleagues (2014) reported that optimum temperature and $\mathrm{pH}$ for growth and lactate production from whey for L. delbrueckii ssp. bulgaricus were $44^{\circ} \mathrm{C}$ and 5.7, respectively. However, the results in figure 3 show that the strains selected in this study produced D-LA up to $90 \%$ (e.e.) in all cases, but the performance of the strains was still better at $37^{\circ} \mathrm{C}$ using OPW hydrolysates.

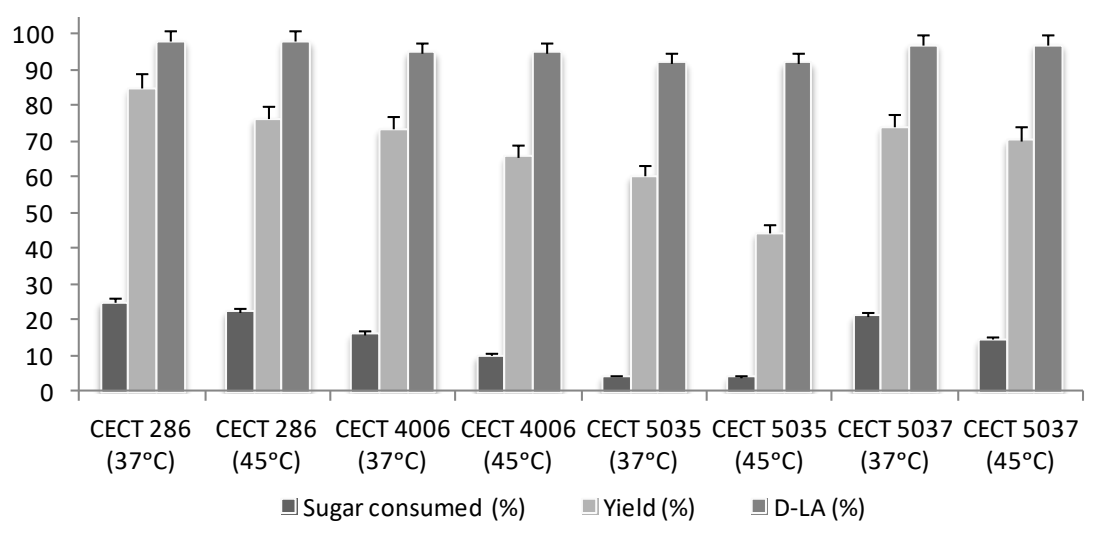

Figure 3. D-LA production results of three L. delbrueckii ssp. bulgaricus selected in front of $L$. delbrueckii ssp. delbrueckii CECT 286 using OPW hydrolysate at $85 \%\left(\mathrm{v} \mathrm{v}^{-}\right)$and incubated at $37^{\circ} \mathrm{C}$ and $45^{\circ} \mathrm{C}$ to compare strains performance at different temperatures. 
Similarly to temperature, the effect of $\mathrm{pH}$ change on growth characteristics varied between different species of $L A B$ and in most cases, a decrease of lactate production with a decrease of $\mathrm{pH}$ were observed (Adamberg et al., 2003). Therefore, the strains were cultured in $85 \%\left(\mathrm{v} \mathrm{v}^{-1}\right)$ OPW hydrolysate and $\mathrm{pH}$ was adjusted to 5.8 each 24 hours during fermentation to test their capacity of production with $\mathrm{pH}$ regulation. Cultures were incubated at $37^{\circ} \mathrm{C}$ and microaerobiosis for 120 hours. The results show that sugar consumption and yields were higher when $\mathrm{pH}$ was adjusted, and D-LA up to 95\% (e.e.) was produced (Figure 4). L. delbrueckii ssp. bulgaricus CECT 5037 showed the best results in comparison to the other L. delbrueckii ssp. bulgaricus strains and its performance was comparable to L. delbrueckii ssp. delbrueckii CECT 286 using OPW hydrolysate, whose productivities were between 0.23 and $0.29 \mathrm{~g} \mathrm{l}^{-1} \mathrm{~h}^{-1}$, respectively. Due to the homofermentation of L. delbrueckii ssp. delbrueckii and L. delbrueckii ssp. bulgaricus (Abdel-Rahman et al., 2013; Zhang and Vadlani, 2013), only lactic acid could be produced. Nevertheless, a small increase in ethanol concentration onwards of $48 \mathrm{~h}$ of fermentation was observed during $\mathrm{pH}$ regulation trials. The explanation for this fact, according to the literature (Hofvendal et al., 2000; Zhang et al., 2018), is that some homofermenters, when grown in limited sugar environment or in the presence of different sugars, can lead to other end products. The main difference is in pyruvate metabolism, but the homofermentation pathway is still used. Additionally, the accumulation of ethanol in the medium $\left(2-3 \mathrm{~g} \mathrm{I}^{-1}\right)$ was by far very low to change significantly the generation of the target product. Thus, D-LA continues to be the major fermentation product, and the metabolism of the strains can be considered homofermentative.

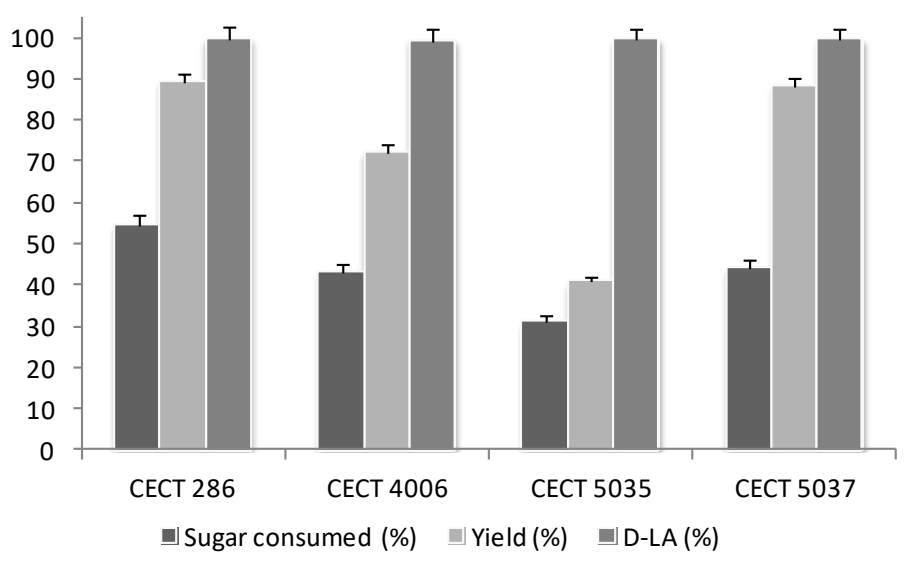

Figure 4. D-LA production results of three $L$. delbrueckii ssp. bulgaricus selected in front of $L$. delbrueckii ssp. delbrueckii CECT 286 using OPW hydrolysate at $85 \%\left(\mathrm{v} \mathrm{v}^{1}{ }^{1}\right)$ and adjusting $\mathrm{pH}$ at 5.8 each 24 hours to evaluate strains performance with $\mathrm{pH}$ regulation. The results of standard deviation for the strains with respect to CECT 286 strain are: $\mathrm{SD}_{\mathrm{CECT} 4006}=12.02 ; \mathrm{SD}_{\mathrm{CECT5035}}=34.22 ; \mathrm{SD}_{\mathrm{CECT5037}}=0.69$. 
5.3.3. D-LA production by L. delbrueckii ssp. delbrueckii CECT 286 vs. L. delbrueckii ssp. bulgaricus CECT 5037.

Preliminary scale-up assays were performed in 1.5 liter bioreactor by controlling pH at 5.8 in batch mode. Previous results showed that the performance of the strains was better under micro-aerobic conditions, so the bioreactor tests were performed under anaerobic conditions using a nitrogen stream. Cells from $15 \%\left(v v^{-1}\right)$ MRS preculture were inoculated in $85 \%\left(v v^{-1}\right)$ OPW hydrolysate with MRS and supplemented with $5 \mathrm{~g} \mathrm{I}^{-1}$ of meat extract. According to literature, the more supplemented the medium, the higher the value of final biomass and the higher the productivity of the lactic acid attainable (Chervaux et al., 2000; Kwon et al., 2000). Previous work showed the importance of meat extract and yeast extract in the production of D-LA, probably not due to the total amount of nitrogen but to the growth factors and vitamins contained in these extracts (de la Torre et al, 2018). Fermentation was finished at 72 hours (Figure 5), L. delbrueckii ssp. delbrueckii CECT 286 produced $45 \mathrm{~g} \mathrm{I}^{-1}$ of lactic acid [99.5\% D-LA (e.e.)] with a yield of $86 \%$ while L. delbrueckii ssp. bulgaricus CECT 5037 produced $39 \mathrm{~g} \mathrm{I}^{-1}$ of lactic acid [99.3\% D-LA (e.e.)] with a yield of $84 \%$.
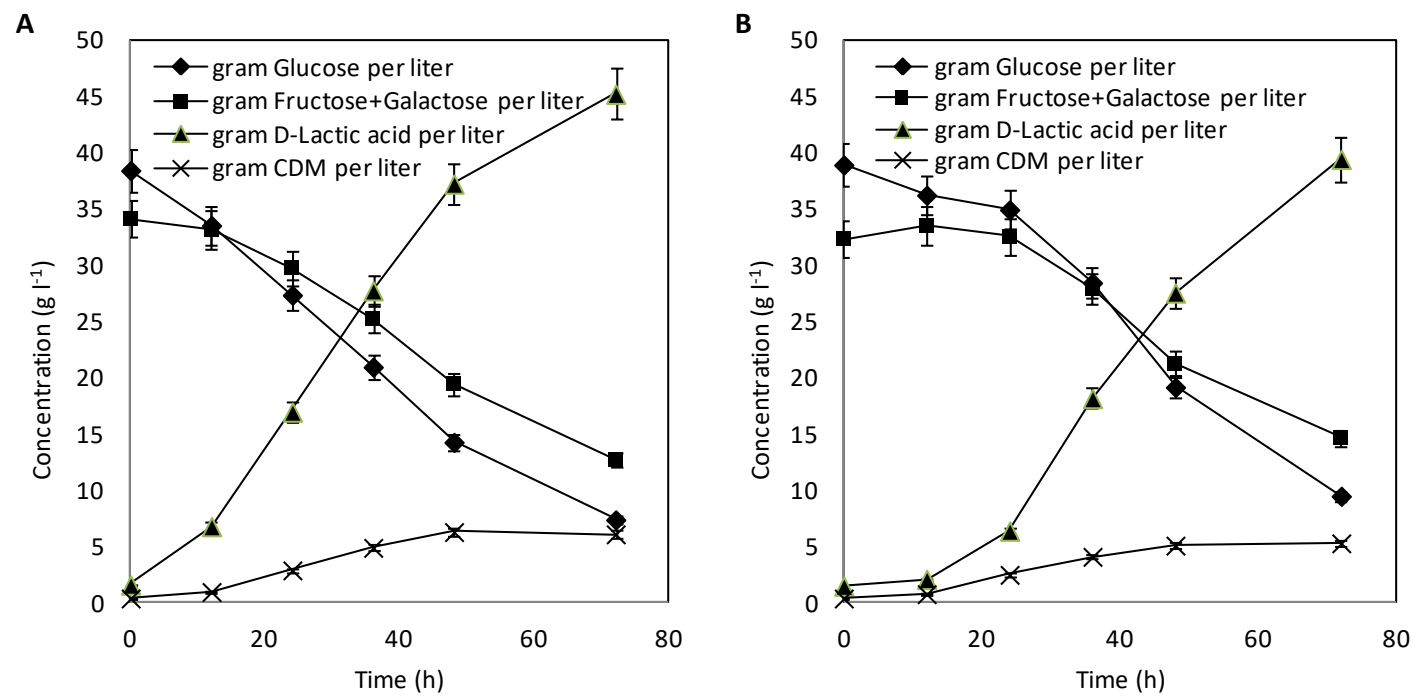

Figure 5. Growth, sugar consumption and D-LA production from OPW hydrolysate in bioreactor and batch mode. A. Lactobacillus delbrueckii ssp. delbreckii CECT 286. B. Lactobacillus delbrueckii ssp. bulgaricus CECT 5037. CDM: Cell dry mass

The yields obtained were similar to those obtained in previous assays by adjusting $\mathrm{pH}$, but the productivities were higher in this case, with values of 0.63 and $0.55 \mathrm{gl}^{-1} \mathrm{~h}^{-1}$, respectively. The experiments show that sugars are not completely consumed during fermentation probably due 
to deficiencies in the nutritional requirements of the strains. Therefore, the D-LA production process is further optimizable using L. delbrueckii ssp. bulgaricus CECT 5037 as a promising DLA producer from OPW hyrolysate and other sustainable feedstocks to contribute in the development of bio-waste refineries. In this regard, commercially important LA-producing LAB strains, such as Lactobacillus and Sporolactobacillus, are particularly useful because of their high lactic acid yield, high acid tolerance, and their ability to be metabolically engineered (Zhang et al., 2013; 2016). Efficient conversion of biomass to D-LA still faces considerable challenges, such as high energy demand and high enzyme cost for pretreatment of lignocellulosic biomass, inefficiency of sugar utilization by microorganisms, and undesired byproducts generated during the fermentation process (Zhang et al., 2018). Table 3 summarizes studies of D-LA production from sustainlable feedstocks such as agro-industrial residues by wild-type stains.

Table 3. D-LA production from sustainable feedstocks in batch cultures by wild-type LAB strains.

\begin{tabular}{|c|c|c|c|c|c|c|}
\hline Feedstock & Microorganism & Process & $\begin{array}{l}\text { Yield } \\
\left(\mathrm{g} \mathrm{g}^{-1}\right)\end{array}$ & $\begin{array}{l}\text { Productivity } \\
\left(\mathrm{g}^{-1} \mathrm{~h}^{-1}\right)\end{array}$ & $\begin{array}{c}\text { D-LA } \\
(\%)\end{array}$ & References \\
\hline Rice starch & L. delbrueckii LD 0028 & SHF & 0.70 & 1.55 & 97.5 & $\begin{array}{l}\text { Fukushima et al. } \\
(2004)\end{array}$ \\
\hline $\begin{array}{l}\text { Defatted rice } \\
\text { bran }\end{array}$ & $\begin{array}{l}\text { L. delbrueckii IFO } \\
3202\end{array}$ & SSF & 0.78 & 1.25 & $>95$ & $\begin{array}{l}\text { Tanaka et al. } \\
\text { (2006) }\end{array}$ \\
\hline $\begin{array}{l}\text { Sugarcane } \\
\text { molasses }\end{array}$ & $\begin{array}{l}\text { L. delbrueckii JCM } \\
1148\end{array}$ & -- & 0.90 & 1.48 & 97.2 & $\begin{array}{l}\text { Calabia and Tokiwa } \\
\text { (2007) }\end{array}$ \\
\hline $\begin{array}{l}\text { Sugarcane } \\
\text { juice }\end{array}$ & $\begin{array}{l}\text { L. delbrueckii JCM } \\
1148\end{array}$ & -- & 0.95 & 1.66 & 98.3 & $\begin{array}{l}\text { Calabia and Tokiwa } \\
\text { (2007) }\end{array}$ \\
\hline $\begin{array}{l}\text { Sugar beet } \\
\text { juice }\end{array}$ & $\begin{array}{l}\text { L. delbrueckii JCM } \\
1148\end{array}$ & -- & 0.88 & 1.16 & 97.6 & $\begin{array}{l}\text { Calabia and Tokiwa } \\
\text { (2007) }\end{array}$ \\
\hline Microalga & $\begin{array}{l}\text { L. coryniformis ssp. } \\
\text { torquens ATCC } 25600\end{array}$ & SSF & 0.46 & 1.02 & 95.8 & $\begin{array}{l}\text { Nguyen et al. } \\
\text { (2012) }\end{array}$ \\
\hline $\begin{array}{l}\text { Curcuma } \\
\text { longa waste }\end{array}$ & $\begin{array}{l}\text { L. coryniformis ssp. } \\
\text { torquens ATCC } 25600\end{array}$ & SSF & 0.65 & 2.08 & $>95$ & $\begin{array}{l}\text { Nguyen et al. } \\
\text { (2013) }\end{array}$ \\
\hline Pulp & $\begin{array}{l}\text { L. delbrueckii ATCC } \\
9649\end{array}$ & SHF & 0.83 & 1.01 & 99 & $\begin{array}{l}\text { Zhang and Vadlani } \\
\text { (2013) }\end{array}$ \\
\hline $\begin{array}{l}\text { Casein whey } \\
\text { permeate }\end{array}$ & $\begin{array}{l}\text { L.delbrueckii ssp. } \\
\text { lactis ATCC } 4797\end{array}$ & -- & 0.49 & 0.61 & $>98$ & $\begin{array}{l}\text { Prasad et al. } \\
\text { (2014) }\end{array}$ \\
\hline $\begin{array}{l}\text { Pulp mill } \\
\text { residues }\end{array}$ & $\begin{array}{l}\text { L. coryniformes ssp. } \\
\text { torquens ATCC } 25600\end{array}$ & SHF & 0.97 & 2.80 & 99 & $\begin{array}{l}\text { de Oliviera Moraes } \\
\text { et al. (2016) }\end{array}$ \\
\hline $\begin{array}{l}\text { Orange peel } \\
\text { waste }\end{array}$ & $\begin{array}{l}\text { L. delbrueckii ssp. } \\
\text { delbrueckii CECT } 286\end{array}$ & SHF & 0.88 & 2.35 & $>95$ & $\begin{array}{l}\text { de la Torre et al. } \\
\text { (2018) }\end{array}$ \\
\hline $\begin{array}{l}\text { Orange peel } \\
\text { waste }\end{array}$ & $\begin{array}{l}\text { L. delbrueckii ssp. } \\
\text { delbrueckii CECT } 286\end{array}$ & SHF & 0.86 & 0.63 & 99.5 & This work \\
\hline $\begin{array}{l}\text { Orange peel } \\
\text { waste }\end{array}$ & $\begin{array}{l}\text { L. delbrueckii ssp. } \\
\text { bulgaricus CECT } 5037\end{array}$ & SHF & 0.84 & 0.55 & 99.3 & This work* \\
\hline
\end{tabular}

* Preliminary results for LAB screening for further optimization.

SSF: Simultaneous saccharification and fermentation; SHF: Separate hydrolysis and fermentation.

These results indicate that OPW hydrolysate is an interesting feedstock for the production of D-LA, since the product yield is close to its theoretical value $\left(1 \mathrm{~g} \mathrm{~g}^{-1}\right)$ in most cases. Apart from 
that, the productivity value is quite high and very attractive when industrial developments are envisaged (de la Torre et al., 2018; 2019). It is common that bioprocesses based on biomass waste give poorer results than their control experiments based on sugar mixtures resembling the hydrolysates composition. In this case, yields achieved have close values in both cases. According to the achieved purity of lactic acid $(>95 \%)$, differences were not observed when OPW hydrolysate is used, suggesting that the waste compounds do not influence D-LA purity.

The results obtained with the L. delbrueckii ssp. bulgaricus CECT 5037 are promising since performance of the strain was comparable to L. delbrueckki ssp. delbrueckii CECT 286 strain performance using OPW hydrolysate at the conditions tested in this work. Previous studies show that the reference strain can reach a productivity of $2.35 \mathrm{~g}^{-1} \mathrm{~h}^{-1}$ when fermentation conditions are optimized (de la Torre et al., 2018). Therefore, future work with L. delbrueckii ssp. bulgaricus CECT 5037 will be focused on optimization of fermentation methodology, including the method of inoculation of the cultures, improvement of culture media by testing low cost nutrient sources, as well as the evaluation of operational costs in developing a sustainable lactic acid production process.

\subsection{Conclusions}

Six strains of the species Lactobacillus delbrueckii ssp. bulgaricus were evaluated for the production of D-LA from OPW hydrolysate in comparison to the reference Lactobacillus delbrueckii ssp. delbrueckii CECT 286 strain. Remarkably, Lactobacillus delbrueckii ssp. bulgaricus CECT 5037 is able to tolerate the OPW hydrolysate and produce D-LA up to 95\% (e.e.). The results of strain performance show a yield of $84 \%$ for lactic acid production that is close to the yield of $86 \%$ obtained with the reference Lactobacillus delbrueckii ssp. delbrueckii CECT 286 strain in this work and 88\% reported from previous works when process improvement was foreseen. Experiments will be underway to develop the process and further optimization will contribute to providing a suitable alternative to biowaste-refinery processes using OPW and other residual feedstocks as a potential substrate for valorisation.

\section{References}

Abdel-Rahman, M.A., Tashiro, Y., Sonomoto, K. (2011) Lactic acid production from lignocellulose-derived sugars using lactic acid bacteria: overview and limits. J Biotechnol 156(4): 286-301 
Abdel-Rahman, M.A., Tashiro, Y., Sonomoto, K. (2013) Recent advances in lactic acid production by microbial fermentation processes. Biotechnol Adv 31(6): 877-902

Adamberga, K., Kaska, S., Lahta, T.M., Paalmea, T., (2003) The effect of temperature and pH on the growth of lactic acid bacteria: a pH-auxostat study. Int J Food Microbiol 85: 171-183

Aghababaie, M., Beheshti, M., Khanahmadi, M. (2014) Effect of temperature and $\mathrm{pH}$ on formulating the kinetic growth parameters and lactic acid production of Lactobacillus bulgaricus. Nutr Food Sci Res 1(1): 49-56

Archibald, F.S., Fridovich, I. (1981) Manganese and defenses against oxygen toxicity in Lactobacillus plantarum. J Bacteriol 145: 442-451

Benthin, S. and Villadsen, J. (1995a) Production of optically pure D-lactate by Lactobacillus bulgaricus and purification by crystallisation and liquid/liquid extraction. Appl Microbiol Biotechnol 42: 826-829

Benthin, S. and Villadsen, J. (1995b) Different inhibition of Lactobacillus delbrueckii subsp. bulgaricus by D- and L-lactic acid: effects on lag phase, growth rate and cell yield. J App/ Biotecnol 78(6): 647-654

Bernard, N., Ferain, T., Garmyn, D., Hols, P., Delcour, J. (1991) Cloning of the D-lactate dehydrogenase gene from Lactobacillus delbrueckii subsp. bulgaricus by complementation in Escherichia coli. FEBS Lett 290: $61-64$

Bevilacqua, A., Corbo, M.R., Sinigaglia, M. (2010) In vitro evaluationof the antimicrobial activity of eugenol, limonene, and citrus extract against bacteriaand yeasts, representative of the spoiling microflora of fruit juices. J Food Prot 73(5): 888-894

Calabia, B.P., Tokiwa, Y. (2007) Production of D-lactic acid from sugar cane molasses, sugarcane juice and sugar beet juice by Lactobacillus delbrueckii. Biotechnol Lett 29(9): 1329-1332

Chervaux, C., Ehrlich, S.D., Maguin, E. (2000) Physiological Study of Lactobacillus delbrueckii subsp. bulgaricus Strains in a Novel Chemically Defined Medium. Appl Environ Microbiol 66(12): 5306-5311.

Choi, M., Al-Zahrani, S.M., Lee, S.Y. (2014) Kinetic model-based feed-forward controlled fed-batch fermentation of Lactobacillus rhamnosus for the production of lactic acid from Arabic date juice. Bioprocess Biosyst Eng 37(6): 1007-1015

Choi, I.S., Lee, Y.G., Khanal, S.K., Park, B.J., Bae, H-J. (2015) A low-energy, cost-effective approach to fruit and citrus peel waste processing for bioethanol production. Appl Energy 140: 65-74

de la Torre, I., Ladero, M., Santos, V.E. (2018) Production of D-lactic acid by Lactobacillus delbrueckii ssp. delbrueckii from orange peel waste: techno-economical assessment of nitrogen sources. Appl Microbiol Biotechnol 102: 10511-10521 
de la Torre, I., Acedos, M.G., Ladero, M., Santos, V.E. (2019) On the use of resting L. delbrueckii spp. delbrueckii cells for D-lactic acid production from orange peel wastes hydrolysates. Biochem Eng J 145: 162-169.

de la Torre, I., Ravelo, M., Segarra, S., Tortajada, M., Santos, V.E., Ladero, M. (2017) Study on the effects of several operational variables on the enzymatic batch saccharification of orange solid waste. Bioresour Technol 245(Part A): 906-915

de Oliveira Moraes, A., Ramirez, N.I.B., Pereira, N. (2016) Evaluation of the fermentation potential of pulp mill residue to produce D (-)-lactic acid by separate hydrolysis and fermentation using Lactobacillus coryniformis subsp. torquens. Appl Biochem biotechnol 180(8): 1574-1585.

Eiteman, M.A., Ramalingam, S. (2015) Microbial production of lactic acid. Biotechnol Lett 37(5):955-972 Esteban, J., Ladero, M. (2018) Food waste as a source of value-added chemicals and materials: a biorefinery perspective. Int J Food Sci Technol 53(5): 1095-1108

Fukushima, K., Sogo, K., Miura, S., Kimura, Y. (2004). Production of D-lactic acid by bacterial fermentation of rice starch. Macromol biosci 4(11): 1021-1027

Girotto, F., Alibardi, L., Cossu, R. (2015) Food waste generation and industrial uses: a review. Waste Manag 45: 32-41

Grobben, G.J., Chin-Joe, I., Kitzen, V.A., Boels, I.C., Boer, F., Sikkema, J., Smith, M.R., De Bont, J.A.M. (1998) Enhancement of exopolysaccharide production by Lactobacillus delbrueckii subsp. bulgaricus NCFB 2772 with a simplified defined medium. Appl Environ Microbiol. 64: 1333-1337.

Idris, A., Suzana, W. (2006) Effect of sodium alginate concentration, bead diameter, initial pH and temperature on lactic acid production from pineapple waste using immobilized Lactobacillus delbrueckii. Process Biochem 41(5): 1117-1123

Hama, S., Mizuno, S., Kihara, M., Tanaka, T., Ogino, C., Noda, H., Kondo, A. (2015) Production of D-lactic acid from hard wood pulp by mechanical milling followed by simultaneous saccharification and fermentation using metabolically engineered Lactobacillus plantarum. Bioresour Technol 187: 167-172

Hofvendahl, K. and Hahn-Hägerdal, B. (2000) Factors affecting the fermentative lactic acid production from renewable resources. Enzyme Microb Technol 26: 87-107

Hu, J., Zhang, Z., Lin, Y., Zhao, S., Mei, Y., Liang, Y., Peng, N. (2015) High-titer lactic acid production from $\mathrm{NaOH}$-pretreated corn stover by Bacillus coagulans LA204 using fed-batch simultaneous saccharification and fermentation under non-sterile condition. Bioresour Technol 182: 251-257

John, R.P., Nampoothiri, K.M., Pandey, A. (2007) Fermentative production of lactic acid from biomass: 
an overview on process developments and future perspectives. Appl Microbiol Biotechnol 74(3): 524534

John, R.P., Anisha, G., Nampoothiri, K.M., Pandey, A. (2009) Direct lactic acid fermentation: focus on simultaneous saccharification and lactic acid production. Biotechnol Adv 27(2):145-152

Klotz, S., Kaufmann, N., Kuenz, A., Prüße, U. (2016) Biotechnological production of enantiomerically pure d-lactic acid. Appl Microbiol Biotechnol 100(22): 9423-9437

Kwon, S., Lee, P.C., Lee, E.G., Chang, Y.K., Chang, N. (2000) Production of lactic acid by Lactobacillus rhamnosus with vitamin-supplemented soybean hydrolysate. Enzym Microb Technol 26(2-4): 209-215

Lugo-Lugo, V., Barrera-Díaz, C., Ureña-Núñez, F., Bilyeu, B., Linares-Hernández, I., (2012) Biosorption of $\mathrm{Cr}(\mathrm{III})$ and $\mathrm{Fe}(\mathrm{III})$ in single and binary systems onto pretreated orange peel. J. Environ. Manage 112: 120127.

Martín, M.A., Siles, J.A., Chica, A.F., Martín, A., (2010) Biomethanization of orange peel waste. Bioresour Technol 101(23): 8993-8999.

Mazzoli, R., Bosco, F., Mizrahi, I., Bayer, E.A., Pessione, E. (2014) Towards lactic acid bacteria-based biorefineries. Biotechnol Adv 32(7): 1216- 1236

Negro, V., Mancini, G., Ruggeri, B., Fino, D. (2016) Citrus waste as feedstock forbio-based products recovery: review on limonene case study and energy valorization. Bioresour Technol 214: 806-815

Nguyen, C.M., Kim, J.S., Song, J.K., Choi, G.J., Choi, Y.H., Jang, K.S., Kim, J.C. (2012) D-lactic acid production from dry biomass of Hydrodictyon reticulatum by simultaneous saccharification and cofermentation using Lactobacillus coryniformis subsp. torquens. Biotechnol Lett 34: 2235-2240

Nguyen, C.M., Kim, J., Nguyen, T.N., Kim, S.K., Choi G.J., Choi. Y.H., Jang, K.S., Kim, J. (2013) Production of L- and D-lactic acid from waste Curcuma longa biomass through simultaneous saccharification and cofermentation. Bioresour Technol 146: 35-43

Oberoi, H.S., Vadlani, P.V., Madl, R.L., Saida, L., Abeykoon, J.P. (2010) Ethanol production from orange peels: two-stage hydrolysis and fermentation studies using optimized parameters through experimental design. J Agric Food Chem 58(6): 3422-3429.

Okano, K., Hama, S., Kihara, M., Noda, H., Tanaka, T., Kondo, A. (2017) Production of optically pure dlactic acid from brown rice using metabolically engineered Lactobacillus plantarum. Appl Microbiol Biotechnol 101(5): 1869-1875

Pourbafrani, M., Forgács, G., Horváth, I.S., Niklasson, C., Taherzadeh, M.J., 2010. Production of biofuels, limonene and pectin from citrus wastes. Bioresour Technol 101(11): 4246-4250. 
Prasad, S., Srikanth, K., Limaye, A.M., Sivaprakasam, S. (2014). Homo-fermentative production of d-lactic acid by Lactobacillus sp. employing casein whey permeate as a raw feed-stock. Biotechnol lett 36(6): 1303-1307

Rafiq, S., Kaul, R., Sofi, S.A., Bashir, N., Nazir, F., Nayik G.A. (2016) Citrus peel as a source of functional ingredient: a review. J Saudi Soc Agric. Sci. 17(4): 351-358.

Rezzadori, K., Benedetti, S., Amante, E.R. (2012) Proposals for the residues recovery: Orange waste as raw material for new products. Food Bioprod Process 90(4): 606-614

Singhvi, M., Zendo, T., Sonomoto, K. (2018) Free lactic acid production under acidic conditions by lactic acid bacteria strains: challenges and future prospects. Appl Microbiol Biotechnol 102(14): 1-14

Sluiter, A., Hames, B., Ruiz, R., Scarlata, C., Sluiter, J., Templeton, D., Crocker, D., (2008a). issue date, 4/25/2008 In: Sluiter, A. (Ed.), Determination of structural carbohydrates and lignin in biomass laboratory analytical procedure (LAP). National Renewable Energy Laboratory, Golden, Colo.

Sluiter, A., Hames, B., Ruiz, R., Scarlata, C., Sluiter, J., Templeton, D., (2006) Determination of Sugars, Byproducts, and Degradation Products in Liquid Fraction Process Samples. National Renewable Energy Laboratory, Golden.

Sluiter, A., Ruiz, R., Scarlata, C., Sluiter, J., Templeton, D., (2008b) issue date, 7/17/2005 In: Sluiter, A. (Ed.), Determination of extractives in biomass laboratory analytical procedure (LAP). National Renewable Energy Laboratory, Golden, Colo.

Tanaka, T., Hoshina, M., Tanabe, S., Sakai, K., Ohtsubo, S., Taniguchi, M. (2006) Production of D-lactid acid from defatted rice bran by simultaneous saccarification and fermentation. Bioresour Technol 97: 211-217

Tashiro, Y., Kaneko, W., Sun, Y., Shibata, K., Inokuma, K., Zendo, T., Sonomoto, K. (2011) Continuous Dlactic acid production by a novel thermo tolerant Lactobacillus delbrueckii subsp. lactis QU 41. Appl Microbiol Biotechnol 89(6): 1741-1750

Van Dyk, J.S., Gama, R., Morrison, D., Swart, S., Pletschke, B.I. (2013) Food processing waste: problems, current management and prospects for utilisation of the lignocellulose component through enzyme synergistic degradation. Renew Sust Energ Rev 26: 521-531

Wang, Y., Tashiro, Y., Sonomoto, K. (2015) Fermentative production of lactic acid from renewable materials: recent achievements, prospects, and limits. J Biosci Bioeng 119(1): 10-18

Zhang, Y., Vadlani, P.V. (2013) D-Lactic acid biosynthesis from biomass derived sugars via Lactobacillus delbrueckii fermentation. Bioprocess Biosyst Eng 36(12): 1897-1904 
Zhang, Y., Vadlani, P.V., Kumar, A., Hardwidge, P.R., Govind, R., Tanaka, T., Kondo, A. (2016) Enhanced Dlactic acid production from renewable resources using engineered Lactobacillus plantarum. Appl Microbiol Biotechnol 100(1): 279-288

Zhang, Y., Yoshida, M., Vadlani, P.V. (2018) Biosynthesis of D-lactic acid from lignocellulosic biomass. Biotechnol lett, 40(8): 1167-1179. 


\section{INTEGRATIVE DISCUSSION}




\section{Renewable bioprocessing to bio-based chemicals and polymers}

The scarcity of raw materials, fossil fuels, that are currently the basis of chemistry, poses a challenge for the future (Brehmer et al., 2009; Mitsos et al., 2018). Although the amount of reserves and their duration is the subject of extensive discussion (Shafiee and Topal, 2009), the price increase that will follow in the future is recognised. This leads us to the use of renewable raw materials and, therefore, to the design of technologies for their exploitation, that is, the design of sustainable processes for the extraction of products from raw materials and for their transformation into products of industrial use, including an efficient supply chain management (Scarlat et al., 2015; Kumar and Singh, 2019). A switch from fossil-based resources to renewable biomass as a feedstock for the manufacture of biofuels, commodity chemicals and biomaterials, such as bio-based plastics is essential for the envisaged decarbonization of society (Sheldon 2014; 2018). An additional benefit could be the substitution of existing products by inherently safer, bio-based alternatives with reduced environmental footprints, such as recyclable and/or biodegradable plastics (de Jong et al., 2012; Maniar et al., 2019).

In general, biotechnological processes are a sustainable alternative to conventional chemical processes by obtaining products from renewable raw materials. Industrial biocatalysts are gaining popularity each day for the purpose of eco-friendliness, cost-effectiveness and longterm sustainability. However, finding a suitable biocatalyst for any particular process fulfilling these criteria is still a challenging task and has to be taken care of for upscaling of the process (Tripathi and Sinha, 2020). This thesis is targeted to the development of this type of bioprocesses with prospects for industrial application as shown in Figure 1. The research process starts determining the potential of the targeted renewable feedstocks in order to select suitable biocatalysts for further process development and optimisation.

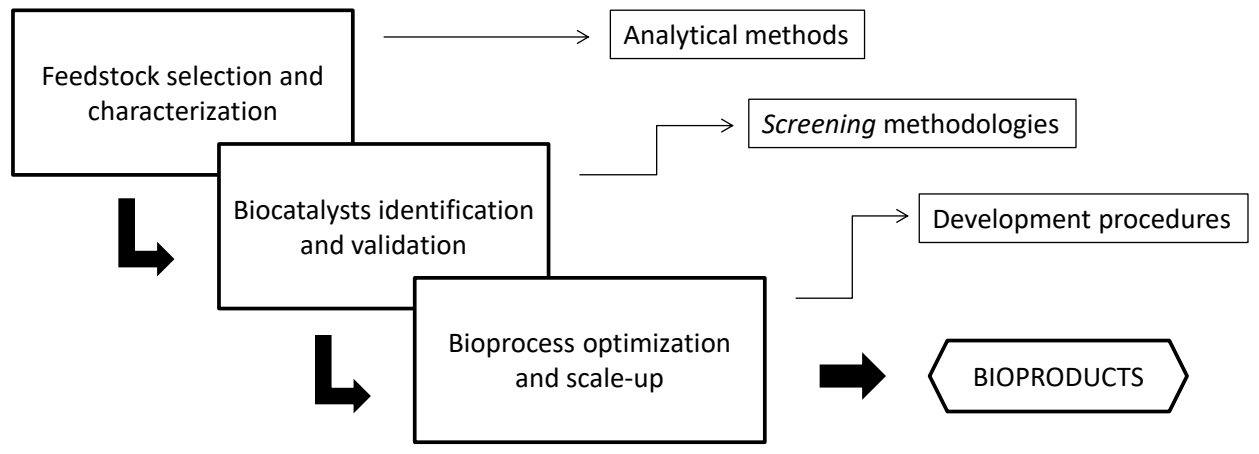

Figure 1. Bioprocesses development in the framework of this thesis. 
Initial feedstock availability, its potential use, and its characteristics need to be considered. Therefore, detailed and accurate characterization of feedstocks, intermediates, and products is a necessity for any bioconversion process, to understand how the individual biomass components and reaction products interact at each stage in the process (Ferreira, 2017). Five different renewable feedstocks were selected for bioprocesses development in the framework of this work: whey, camelina oil, crude glycerol, organic waste and orange peel waste. Table 1 summarises the bioprocesses developed in this thesis including the methodologies applied for biocatalysts identification in each case. The nature of the raw material determines the choice of biocatalyst depending on the bioproduct of interest. Therefore, it has been necessary to identify and select suitable biocatalysts for each substrate for the development of an adequate bioconversion process to obtain the corresponding bioproduct.

Table 1. Summary of bioprocesses developed in this thesis and the biocatalysts identified.

\begin{tabular}{ccccccc}
\hline $\begin{array}{c}\text { Feedstock } \\
\text { (Substrate) }\end{array}$ & $\begin{array}{c}\text { Conditioning } \\
\text { procedures }\end{array}$ & $\begin{array}{c}\text { Substrate } \\
\text { characterisation }\end{array}$ & $\begin{array}{c}\text { Biocatalyst } \\
\text { selection }\end{array}$ & $\begin{array}{c}\text { Biocatalyst } \\
\text { selected }\end{array}$ & $\begin{array}{c}\text { Bioprocess } \\
\text { regime }\end{array}$ & Bioproduct \\
\hline $\begin{array}{c}\text { Whey } \\
\text { (Lactose) }\end{array}$ & $\begin{array}{c}\text { Filtration } \\
\text { Freeze-drying }\end{array}$ & $\begin{array}{c}\text { HPLC, liquid } \\
\text { chromatography }\end{array}$ & $\begin{array}{c}\text { In silico } \\
\text { bioprospecting }\end{array}$ & $\begin{array}{c}\text { Caulobacter } \\
\text { segnis }\end{array}$ & Fed-batch & PHB \\
\hline $\begin{array}{c}\text { Camelina Oil } \\
\text { (Lipids) }\end{array}$ & $\begin{array}{c}\text { Refining } \\
\text { Saponification }\end{array}$ & $\begin{array}{c}\text { GC, Gas } \\
\text { chromatography }\end{array}$ & $\begin{array}{c}\text { Strain } \\
\text { evaluation }\end{array}$ & $\begin{array}{c}\text { Pseudomonas } \\
\text { resinovorans }\end{array}$ & Fed-batch & Mcl-PHA \\
\hline $\begin{array}{c}\text { Crude glycerol } \\
\text { (Glycerol) }\end{array}$ & None & $\begin{array}{c}\text { HPLiquid } \\
\text { chromatography }\end{array}$ & $\begin{array}{c}\text { Random } \\
\text { mutagenesis }\end{array}$ & $\begin{array}{c}\text { Raoultella } \\
\text { planticola }\end{array}$ & Batch & 2,3-BD \\
\hline $\begin{array}{c}\text { Organic waste } \\
\text { (Sugars) }\end{array}$ & $\begin{array}{c}\text { Composting } \\
\text { Hydrolysis }\end{array}$ & $\begin{array}{c}\text { NREL standard } \\
\text { methodology }\end{array}$ & $\begin{array}{c}\text { Strain } \\
\text { evaluation }\end{array}$ & $\begin{array}{c}\text { Raoultella } \\
\text { planticola }\end{array}$ & Fed-batch & 2,3-BD \\
\hline $\begin{array}{c}\text { Orange waste } \\
\text { (Sugars) }\end{array}$ & $\begin{array}{c}\text { Blade-milling } \\
\text { Hydrolysis }\end{array}$ & $\begin{array}{c}\text { NREL standard } \\
\text { methodology }\end{array}$ & $\begin{array}{c}\text { Strain } \\
\text { screening }\end{array}$ & $\begin{array}{c}\text { Lactobacillus } \\
\text { bulgaricus }\end{array}$ & Batch & D-LA \\
\hline
\end{tabular}

NREL: National Renewable Energy Laboratory. PHB: polyhydroxybutyrate; Mcl-PHA: medium-chain-lenght polyhydroxyalkanoate; 2,3-BD: 2,3-butanediol; D-LA: D-lactic acid.

Biocatalysts, enzymes or microorganisms, are crucial in the conversion of renewable feedstocks. Enzymes can participate in pre-treatment and/or hydrolysis processes of the starting raw materials in order to release the substrates of interest, e.g. sugars from polysaccharides, fatty acids from lipids, aminoacids from proteins, etc. These substrates, in turn, can be biotransformed into bioproducts by more complex routes using whole microorganisms in the fermentation processes (Sheldon, 2020). These processes constitute the heart of bioprocesses whose optimal conditions (temperature, pressure, type of reactor, regime, etc.) will be given by the type of biocatalyst selected and the final bioproduct. Synthetic biology and genetic engineering techniques are very useful tools for obtaining biocatalysts for industrial application and for the development of bioprocesses using renewable feedstocks (Clarke and Kitney, 2020). Nevertheless, as has shown in Tabla 1, this work has been focused on the identification and improvement of wild-type biocatalysts 
selected from databases and specialised literature related to the feedstocks of interest without genetic modified organisms (GMOs) generation. After screening methodologies, the best candidates for the processes developed in this work were selected and validated, and thus, the main results obtained during process optimization are shown in Table 2 . The validation of the biocatalysts with industrial interest has been possible by implementing different strategies to address and develop each bioprocess (depending on the nature of the raw material and the bioproduct of interest as previously mentioned).

Table 2. Main results and important outcomes of the bioprocesses developed in this thesis

\begin{tabular}{|c|c|c|}
\hline Bioprocess & Main results & Important outcomes \\
\hline $\begin{array}{l}\text { PHB from whey } \\
\text { (Caulobacter segnis) }\end{array}$ & $\begin{array}{l}\text { Flask: } 31.5 \% \text { PHB and } 1.5 \mathrm{gl}^{-1} \\
\text { Reactor: } 37 \% \mathrm{PHB} \text { and } 9.3 \mathrm{gl}^{-1}\end{array}$ & $\begin{array}{l}\text { In silico bioprospection implemented. } \\
\text { Novel strain identified and validated. }\end{array}$ \\
\hline $\begin{array}{l}\text { Mcl-PHA from camelina oil } \\
\text { (Pseudomonas resinovorans) }\end{array}$ & $\begin{array}{l}\text { Flask: } 28.7 \% \text { PHA and } 3.1 \mathrm{gl}^{-1} \\
\text { Reactor: } 35.5 \% \text { PHA and } 13.5 \mathrm{gl}^{-1}\end{array}$ & $\begin{array}{l}\text { First time substrate evaluation. } \\
\text { Direct substrate fermentation. }\end{array}$ \\
\hline $\begin{array}{l}\text { 2,3-BD from glycerol } \\
\text { (Raoultella planticola) }\end{array}$ & $\begin{array}{l}\text { Flask: } 23.4 \mathrm{gl}^{-1} \text { and } 0.38 \text { yield } \\
\text { Reactor: } 33.6 \mathrm{gl}^{-1} \text { and } 0.54 \text { yield }\end{array}$ & $\begin{array}{l}\text { Random mutagenesis implemented. } \\
\text { Improved strains validated. }\end{array}$ \\
\hline $\begin{array}{l}\text { 2,3-BD from organic waste } \\
\text { (Raoultella planticola) }\end{array}$ & $\begin{array}{l}\text { Flask: } 15 \mathrm{gl}^{-1} \text { and } 0.5 \text { yield } \\
\text { Reactor: } 50 \mathrm{gl}^{-1} \text { and } 0.5 \text { yield }\end{array}$ & $\begin{array}{l}\text { Improved strains validated. } \\
\text { Process developed and upscaled. }\end{array}$ \\
\hline $\begin{array}{l}\text { D-LA from citrus waste } \\
\text { (Lactobacillus bulgaricus) }\end{array}$ & $\begin{array}{l}\text { Flask: } 0.23 \mathrm{gl}^{-1} \mathrm{~h}^{-1} \text { and }>99 \% \text { e.e. } \\
\text { Reactor: } 0.55 \mathrm{gl}^{-1} \mathrm{~h}^{-1} \text { and }>99 \% \text { e.e. }\end{array}$ & $\begin{array}{l}\text { Strain screening on the substrate. } \\
\text { New strain selected and validated. }\end{array}$ \\
\hline
\end{tabular}

The strategies implemented in this work are based in several premises or hypotheses from which the different processes have been developed and can be summarised as follows:

$>$ Identification of biocatalysts capable of transform raw materials without any pretreatment (i.e. no hydrolysis steps).

$>$ Identification and improvement of biocatalysts applying random mutagenesis techniques (i.e. no direct mutagenesis techniques).

$>$ Identification of new biocatalysts with better or similar performance to those already described in the literature (i.e. related strains).

The biocatalysts and the processes developed for each type of bioproduct throughout this thesis are reviewed and discussed as follows (according to the premises mentioned above).

\section{Direct Polyhydroxyalkanoates production from food byproducts}

Food surplus and byproducts can be exploited as low-cost feedstocks for the development of biotechnological processes. There are few bacterial strains able to transform complex substrates directly to produce PHAs, which could reduce process steps and therefore reduce costs and increase scale-up suitability (Kosseva and Rusbandi, 2018). PHAs production has 
been pursued using whey and camelina oil as feedstock without any pre-treatment.

Whey is one of the most polluting materials generated by the food industry with high organic content, and therefore, the optimization of PHA processes is an interesting approach for exploiting its potential. In Chapter I, an in silico bioprospecting methodology was designed to find microorganisms containing genes to express the enzymes that can transform lactose of whey into PHA (galactosidase and PHA polymerases). Although around fifty bacterial strains were identified (through literature, protein databases and genomes), strains described as pathogenic or those requiring growth conditions difficult to reproduce on an industrial scale were discarded. Therefore, the production of PHAs strains was evaluated with twenty strains through a method of lipids staining with Nile-red. Finally, Caulobacter segnis DSM 29236 was identified as a new biocatalyst for the development of the PHB production process from whey (as has been shown in Table 2) after a funnel screening strategy in flask and the subsequent micro-reactor and bioreactor validation assays.

Non-edible vegetable oils can be considered as promising substitutions for traditional edible food crops for biodiesel and biomaterial sustainable production. In Chapter II, the production of mcl-PHA was evaluated using Pseudomonas sp. strains described for their ability to produce this type of polymers from several substrates. In addition, Camelina oil (obtained from a nonfood competing crop), was for the first time evaluated for the production of mcl-PHA. Through a literature search, the strain Pseudomonas resinovorans DSM 21078 was identified and selected as a promising biocatalyst. This strain was able to produce the polymer from crude camelina oil at levels similar to those obtained using Pseudomonas putida and Pseudomonas oleovorans strains by adding lipases to the culture medium. The results obtained matches the best result reported for mcl-PHA production using plant oils (as has been shown in Table 2) during bioreactor assays.

Future advances in systems and synthetic biology will enable the design and construction of robust and PHA hyperproducing strains for industrial use (Chen and Jiang, 2017; Nikel and de Lorenzo, 2018). Meanwhile, wild type strains capable of producing PHAs from whey and camelina oil directly has beed identified avoiding genetic engineering techniques to obtain GMOs. As PHAs has been validated in food and biomedical applications (Sabapathy et al., 2020; Koller, 2021), the bioprocesses developed in this thesis represent a relevant advance for the circular bioeconomy, especially for the food value chain. This means a progress in the development of sustainable processes and technologies for bioplastics production taking into account its importance in the EU legislation against plastics and residues contamination. 
Improvement and upscaling of 2,3-butanediol production from bioresidues

Microbial production of 2,3-BD has especially attracted as an alternative way to the petroleum-based production. However, 2,3-BD production has always been hampered by low yields and high production costs (Hakizimana et al., 2020). The enhanced production of 2,3-BD requires screening of the best strains and a systematic optimization of fermentation conditions (including biocatalysts improvement when needed). The main 2,3-BD producers described are pathogenic strains (i.e., Klepsiella pneumoniae listed as a group risk 2 biological agent), which makes it unsuitable for industrial-scale fermentation. In addition, the bioconversion of industrial byproducts (such as glycerol or agricultural waste) or the use of excess biomass (such as wood hydrolysate), are an ideal solution for base chemical production.

Glycerol is one of the most interesting substrate for 2,3-BD production taking into account that about $100 \mathrm{~kg}$ of crude gluycerol are generated per ton of product in biodiesel production. In Chapter III, the 2,3-BD production process from glycerol was developed by improving the wildtype strain Raoultella planticola CECT 843 . This strain was subjected to random mutagensis procedures using ultraviolet light (UV) and ethyl sulphonate (EMS) and the so-called proton suicide method for the selection of the strains with best performance. Two improved strains (Roaultella planticola CECT 8158 and CECT 8159) were identified and validated for the production of 2,3-BD from glycerol with high yields through this methodology (as has been shown in Table 2). Therefore, the fermentation conditions were properly optimized using improved strains from a risk-1 Raoultella planticola providing an alternative for biorefinery processes using bioresidues and contributing in the development of safer and more sustainable processes.

Biowaste represents an important share of European municipal waste generation. In 2017, the EU-28 generated 249 million tonnes of municipal solid waste (Eurostat, 2019), of which about $34 \%$, or 86 million tonnes, was biowaste. In Chapter IV, improved Raoultella planticolla strains in turn were tested for the production of 2,3-BD from organic waste hydrolysates, together with Bacillus licheniformis DSM 8785. In contrast to previous processes, the utilisation of organic waste requires enzymatic hydrolysis steps (i.e. using cellulase cocktails) to release the sugars that serve as fermentation substrate. The strains of Roultella planticola (wild-type and improved strains) were shown to be robust for this process, as they were able to tolerate the inhibitors of the biowaste hydrolysates and concentrates used during the development of the fermentation process (as has been shown in Table 2). In the end, Raoultella planticola CECT 843 were used for the upscaling of the process in a semi-industrial plant (WO2019180220A1). 
The bioprocesses developed in this thesis represent an step forward to achieve 2,3-BD production efficiently and a relevant advanced for the circular bioeconomy. The development of a biorefinery concept using bioresidues as feedstock to obtain value-added products could create the profitability margin required for the reduction of the production cost of 2,3-BD (Koutinas et al., 2016; Fulgence et al., 2018). One of the biggest problems is the development of a cost-competitive downstream separation process with low environmental impact.

\section{Production of D-lactic acid with high enantiomeric excess using citrus waste}

Lactic acid is an important chemical due its application, among many others, in the production of the biodegradable polymer polylactic acid. Polymeric properties are determined by the proportion of L- and D-Lactic acid monomers or oligomers, the main issue is the limited knowledge of D-LA biosynthesis (Ahmad et al., 2020; Rawoof et al., 2020). In addition, Lactobacillus bulgaricus was identified as potential candidate for lactic acid production from sustainable feedstocks with high enantiomeric excess.

Orange waste is the most abundant citrus waste and its composition (i.e., high sugar content and low lignin) makes it ideal substrate for fermentation. In Chapter V, the D-LA production process has been studied with the aim of searching for new strains capable of transforming sugars from orange peel waste hydrolysates into D-LA with enantiomeric specificity. As with organic waste, it was necessary to implement enzymatic hydrolysis methods on the raw material to release the sugars for fermentation. Subsequently, a screening of lactic acid bacteria strains was carried out, with which the Lactobacillus delbrueckii ssp. bulgaricus CECT 5037 strain was selected with similar performance to the previously described Lactobacillus delbrueckii ssp. delbrueckii 286 in batch cultures. Therefore, this strain is able to transform sugars from orange peel hydrolysate into D-LA (as has been shown in Table 2) with high yield and high enantiomeric excess.

Efficient conversion of biomass into D-LA still have important challenges, such as high enzyme cost for pretreatment of feedstock, inefficiency of substrates utilization by microorganisms, undesired byproducts generated during the fermentation process and high energy consumption (Zhang et al., 2018). Future work with L. delbrueckii ssp. bulgaricus CECT 5037 will be focused on optimization of fermentation methodology and the evaluation of operational costs in developing a sustainable lactic acid production process. Recently, adaptative laboratory evolution was reported as powerful strategy for enhancing D-LA production from agro-industrial wastes (Liang et al., 2020). 


\section{Prospects for bioprocesses development using renewable resources}

Biotechnology is revolutionizing industrial and agricultural practices by improving quantity and quality of products. In addition, the number of commercial biotechnology products is increasing each year (Lokko et al., 2018). With revenues of more than $\$ 300$ billion, biotechnology's role goes beyond industrial growth, offering opportunities to advance many of the UN's Sustainable Development Goals (SDGs). Although the uptake of these technologies is routine in industrialized countries, many developing countries however, are lagging behind in adopting some of these modern biotechnologies for the sustainable growth of industry. Fermentation is one of the oldest forms of biotechnology and a key component of many industrial applications involving the processing of biological material. Enzyme biocatalysis is another major biotechnology with wide industrial application. Although a lot of research is being conducted related to industrial biocatalysts, future of industrial biocatalysis lies in process sustainability in terms of economy and eco-friendliness (Tripathi and Sinha, 2020). Multi-disciplinary approaches for generation of functional biocatalysis will lead the way in the future. Further need for process sustainability and economic consideration are forcing researchers to take the route of in silico biology and high-level computational methods.

The transition from fossil-based to bio-based feedstocks requires a very different approach to feedstock supply. Fermentation and biomass lend themselves to the development of smallerscale, distributed operations, more akin to farm-based anaerobic digestion than large-scale petrochemical facilities. Partnering and forming joint ventures have been commonly used to assemble the necessary resources and expertise and to help de-risk the technology prior to making major capital investments. The ongoing development of synthetic biology for chemical processes is helping to accelerate (and reduce the costs of) such co-developments (Clarke and kitney, 2020). Companies that have already developed commercial biotechnology processes may work directly with service providers to access latest technological techniques to achieve further optimisation, or to optimise or access improved biocatalysts. Therefore, syntetic biology and industrial biotechnology are recognaised as key platforms for the growth of the bioeconomy.

The potential that lies in biocatalysts improving and intensified fermentation methods coupled with optimization procedures as well as making worthy fermentation systems will enable the development of efficient and economically feasible bioprocesses. However, in contrast to chemical industries, current industrial biotechnology is still not competitive for production of 
chemicals, materials, and biofuels due to their low efficiency and complicated sterilization processes as well as high-energy consumption. It must be further developed into "nextgeneration industrial biotechnology", which is low-cost mixed substrates based on less freshwater consumption, energy-saving, and long-lasting open continuous intelligent processing, overcoming the shortcomings of current industrial biotechnology and transforming it into competitive processes ( $\mathrm{Yu}$ et al., 2019). In addition, contamination-resistant microorganism as chassis is the key, which requires resistance to microbial or phage contaminations, and available tools and methods for metabolic or synthetic biology engineering.

Adaptive laboratory evolution stands as a powerful tool available to strain engineers and biologists, yielding strains with phenotypic improvements that stem from random mutation and natural selection rather than rational engineering (Sandberg et al., 2019). Based on the development of automatic devices and rapid assay methods, various high-throughput screening strategies have been established for improving the performance of industrial microorganisms (Zeng et al., 2020). The most significant factors that can improve highthroughput screening efficiency include the construction of screening libraries with high diversity and the use of new detection methods to expand the search range and highlight target compounds. Therefore, the development of techniques to identify and improve industrial biocatalysts for the transformation of renewable feedstocks will contribute to the development of sustainable bioprocesses to move towards a circular bioeconomy.

\section{References}

Ahmad, A., Banat, F., Taher, H. (2020) A review on the lactic acid fermentation from low-cost renewable materials: recent developments and challenges. Environ Technol Inno 20, 101138.

Brehmer, B., Boom, R. M., Sanders, J. (2009) Maximum fossil fuel feedstock replacement potential of petrochemicals via biorefineries. Chem Eng Res Design, 87(9), 1103-1119.

Chen, G.Q., and Jiang, X. (2017) Engineering bacteria for enhanced polyhydroxyalkanoates (PHA) biosynthesis. Synth Syst Biotechnol 2: 192-197.

Clarke, L. and Kitney, R. (2020) Developing synthetic biology for industrial biotechnology applications. Biochem Soc Trans 48(1), 113-122. 
de Jong, E., Higson, A., Walsh, P., Wellisch, M. (2012) Product developments in the bio-based chemicals arena. Biofuels Bioprod Bioref 6, 606-624. Doi:10.1002/bbb.1360.

Ferreira, A.F. (2017). Biorefinery concept. In Biorefineries (pp. 1-20). Springer, Cham.

Fulgence, S., Yan, X., Cong, R. (2018) Current advances in the production of 2,3-butanediolby microbial fermentation. J Acad Ind Res 6: 188-197.

Hakizimana, O., Matabaro, E., Lee, B.H. (2020) The current strategies and parameters for the enhanced microbial production of 2, 3-butanediol. Biotechnol Rep, 25, e00397.

Koller, M. (2021) Production, properties, and processing of microbial polyhydroxyalkanoate (PHA) biopolyesters. In Microbial and Natural Macromolecules (pp. 3-55). Academic Press.

Kosseva, M.R. and Rusbandi, E. (2018) Trends in the biomanufacture of polyhydroxyalkanoates with focus on downstream processing. Int J Biol Macromol 107, 762-778.

Koutinas, A.A., Yepez, B., Kopsahelis, N., Freire, D.M., de Castro, A.M., Papanikolaou, S., Kookos, I.K. (2016) Techno-economic evaluation of a complete bioprocess for 2, 3-butanediol production from renewable resources. Bioresour Technol 204, 55-64.

Kumar, D. and Singh, B. (2019) Role of biomass supply chain management in sustainable bioenergy production. Biofuels 10(1), 109-119.

Liang, S., Jiang, W., Song, Y., Zhou, S.F. (2020) Improvement and Metabolomics-Based Analysis of DLactic Acid Production from Agro-Industrial Wastes by Lactobacillus delbrueckii Submitted to Adaptive Laboratory Evolution. J Agric Food Chem 68(29), 7660-7669.

Lokko, Y., Heijde, M., Schebesta, K., Scholtès, P., Van Montagu, M., Giacca, M. (2018) Biotechnology and the bioeconomy-Towards inclusive and sustainable industrial development. N Biotechnol 40, 5-10.

Maniar, D., Jiang, Y., Woortman, A.J.J., van Dijken, J., Loos, K. (2019) Furan-based copolyesters from renewable resources: enzymatic synthesis and properties. ChemSusChem 12, 1-11. Doi:10.1002/cssc.201802867.

Mitsos, A., Asprion, N., Floudas, C.A., Bortz, M., Baldea, M., Bonvin, D., Casparin, A., Schäfer, P. (2018) Challenges in process optimization for new feedstocks and energy sources. Comput Chem Eng 113, 209221.

Nikel, P.I. and de Lorenzo, V. (2018) Pseudomonas putida as a functional chassis for industrial biocatalysis: from native biochemistry to trans-metabolism. Metab Eng 50, 142-155.

Rawoof, S.A.A., Kumar, P.S., Vo, D.V.N., Devaraj, K., Mani, Y., Devaraj, T., Subramanian, S. (2020) 
Production of optically pure lactic acid by microbial fermentation: a review. Environ Chem Lett 19, 539556.

Sabapathy, P.C. Devaraj, S., Meixner, K., Anburajan, P., Kathirvel, P., Ravikumar, Y., Zabed, H.M., Qi, X. (2020) Recent developments in Polyhydroxyalkanoates (PHAs) production-A review. Bioresour Technol 306, 123132.

Sandberg, T.E., Salazar, M.J., Weng, L.L., Palsson, B.O., Feist, A.M. (2019). The emergence of adaptive laboratory evolution as an efficient tool for biological discovery and industrial biotechnology. Metab Eng $56,1-16$

Scarlat, N., Dallemand, J.F., Monforti-Ferrario, F., Nita, V. (2015) The role of biomass and bioenergy in a future bioeconomy: Policies and facts. Environ Dev 15, 3-34.

Shafiee, S. and Topal, E. (2009) When will fossil fuel reserves be diminished?. Energy policy, 37(1), 181189.

Sheldon, R.A. (2014) Green and sustainable manufacture of chemicals from biomass: state of the art. Green Chem 16, 950-963. Doi:10.1039/C3GC41935E.

Sheldon, R.A. (2018) The road to biorenewables: carbohydrates to commodity chemicals. ACS Sustain Chem Eng 6, 4464-4480. Doi:10.1021/acssuschemeng.8b00376.

Tripathi, P. and Sinha, S. (2020) Industrial Biocatalysis: An Insight into Trends and Future Directions. Current Sustainable/Renewable Energy Reports 7, 66-72.

Yu, L.P., Wu, F.Q., Chen, G.Q. (2019) Next-Generation Industrial Biotechnology-transforming the current industrial biotechnology into competitive processes. Biotechnol J 14(9), 1800437.

Zeng, W., Guo, L., Xu, S., Chen, J., Zhou, J. (2020) High-throughput screening technology in industrial biotechnology. Trends Biotechnol 38(8): 888-906.

Zhang, Y., Yoshida, M., Vadlani, P.V. (2018) Biosynthesis of D-lactic acid from lignocellulosic biomass. Biotechnol lett, 40(8): 1167-1179. 
CONCLUSIONS AND FUTURE WORK 
The main conclusions of this thesis are listed as follows:

The renewable raw materials selected for this work have been properly characterised by means of the corresponding analytical techniques. The selection of appropiate pretreatment methods and routes for the use of each feedstock was based on the results of its characterization and the bioproduct of interest.

Microorganism identification and selection techniques such as in silico prospection and random mutagenesis have been successfully implemented and validated throughout this work. These techniques, together with culture evaluation procedures, have made it possible to obtain biocatalysts of industrial interest.

Biocatalysts capable of direct transformation of food byproducts for the production of polyhydroxyalkanoates have been identified and selected:

- Caulobacter segnis DSM 29236 was selected as a suitable strain to develop a process for whey surplus valorization after in silico prospection. This microorganism accumulated $31.5 \%$ of cell dry weight of poly(3-hydroxybutyrate) with a titer of $1.5 \mathrm{~g} \mathrm{I}^{-1}$ in batch assays under optimized conditions. Moreover, the strain accumulated $37 \%$ of cell dry wight of poly(3-hydroxybutyrate) and $9.3 \mathrm{gl}^{-1}$ in fed-batch mode of operation with potential of improvement.

- Pseudomonas resinovorans DSM 21078 was used for direct fermentation of Camelina oil without prior hydrolysis. A first approach to process development in bioreactor provided up to $40 \%\left(\mathrm{w} \mathrm{w}^{-1}\right)$ polymer content, matching highest medium-chain-length polyhydroxyalkanoates titer reported from plant oils $\left(13.2 \mathrm{~g}^{-1}\right)$. Camelina oil was shown to be a suitable substrate for production of medium-chain-length polyhydroxyalkanoates and was for the first time tested for this porpuse.

Improved and safer biocatalysts for the efficient production of 2,3-butanediol from bioresidues have been obtained:

- Raoultella planticola CECT 843 was subjected to random mutagenesis using ultra-violet light and ethyl methane sulfonate. Two mutant strains were found to produce at least 30\% more 2,3-butanediol than the wild type: $R$. planticola CECT 8158 (33.8 $\mathrm{g} \mathrm{I}^{-1}$ and $54 \%$ yield) and R. planticola DSM 8159 (30.5 $\mathrm{gl}^{-1}$ and $49 \%$ yield). These results exceed the best data previously reported for 2,3-butanediol from glycerol.

- Raoultella planticola (wild-type and improved strains) showed high tolerance and good yields using organic waste hydrolysates as substrate in flask trials. Fed-batch strategy in bioreactor using Raoultella planticola CECT 843 led to the production of $54 \mathrm{~g} \mathrm{I}^{-1}$ of 2,3-butanediol and the process was successfully upscaled at demo scale. 
$\checkmark$ A biocatalyst has been identified for the production of D-lactic acid with high enantiomeric excess from citrus waste:

- Lactobacillus delbrueckii ssp. bulgaricus CECT 5037 is able to tolerate the orange peel hydrolysate and produce D-lactic acid up to $95 \%$ enantiomeric excess. The results of strain performance show a yield of $84 \%$ for lactic acid production that is close to the yield of $86 \%$ obtained with the reference Lactobacillus delbrueckii ssp. delbrueckii CECT 286 strain in this work and $88 \%$ reported from previous works when process improvement was foreseen.

$\checkmark$ The results obtained in this work are a promising step in the design and development of sustainable and safer biotechnological processes to produce bio-based chemicals and polymers from renewable feedstocks. In this regard, the synthesis and use of bio-based polymers are a good alternative to replace the petroleum derivatives towards sustainable development.

The development of techniques to identify and improve industrial biocatalysts for the transformation of renewable feedstocks will contribute to the development of sustainable bioprocesses to move towards a circular bioeconomy.

Future work arising from the results obtained from this thesis may include:

* The improvement and optimisation of bioprocesses developed to increase its potential of implementation.

* The study of the potential of upscaling and implementation of the bioprocesses presented.

* The analysis of the techno-economic feasibility of bioprocesses, especially the feasibility of the process already upscaled and demonstrated.

* The establishment of the value chain for the bioprocesses under study to perform a life cycle assessment.

* The study of the use of the biocatalysts identified in this work for the development of new bioprocesses with other renewable feedstocks. 


\section{CONTRIBUTIONS}

i. Bustamante, D.A., Segarra, S., Rojas, A., Tortajada, M., Ramón, D. (2016) Polyhydroxyalkanoate production from whey by Caulobacter segnis. International BIO.IBEROAMERICA-BIOTEC Congress. Salamanca (Spain) - Oral Communication.

ii. Bustamante, D.A., Segarra, S., Rojas, A., Tortajada, M., Ramón, D. (2016) Production of D-lactic acid from orange peel waste: Strain selection and optimization. International BIO.IBEROAMERICA-BIOTEC Congress. Salamanca (Spain) - Poster.

iii. Bustamante, D.A. (2016) Biotecnología Industrial: alternativas a los procesos químicos convencionales. XIII Simposio de Investigadores Jóvenes de la RSEQ. Logroño (Spain) - Oral Communication.

iv. Bustamante, D.A., del Campo, I., Alegria, I., Sanchez, D., Gil, J. (2019) Scaling-Up continuous lignocellulosic biobutanol production. BIOTEC congress. Vigo (Spain) - Oral Communication.

v. Bustamante, D.A., Rojas, A., Tortajada, M., Ramón, D. (2019) Medium chain length polyhydroxyalkanoates production from Camelina oil. BIOTEC congress. Vigo (Spain) - Poster. 


\section{Index of abbreviations}

\begin{tabular}{|c|c|c|c|}
\hline 2,3-BD & 2,3-Butanediol & MSW & Municipal solid waste \\
\hline ATCC & American type culture collection & NA & Nutrient agar \\
\hline BLAST & Basic local alignment search tool & NB & Nutrient broth \\
\hline CDM & Cell dry mass & NCIMB & British type culture collection \\
\hline CDW & Cell dry weight & NREL & National Renewable Energy Laboratory \\
\hline CECT & Spanish type culture collection & $\mathrm{OD}_{600}$ & Optical density at $600 \mathrm{~nm}$ \\
\hline CFU & Colony-forming unit & OFMSW & Organic fraction of municipal waste \\
\hline$D, L-L A$ & D- and L-Lactic acid & OPW & Orange peel waste \\
\hline DOE & Design of experiments & PHA & Polyhydroxyalkanoate \\
\hline DSMZ & German type culture collection & scl-PHA & Short chain lenght - PHA \\
\hline e.e. & Enantiomeric excess & mcl-PHA & Medium chain lenght - PHA \\
\hline EMS & Ethyl methanesulfonate & $\mathrm{PHB}$ & Polyhydroxybutyrate \\
\hline GC & Gas chromatography & PHBV & Polyhydroxy(butyrate-co-valerate) \\
\hline GMO & Genetically modified Organism & $\mathrm{PHO}$ & Polyhydroxy(hexanoate-co-octanoate) \\
\hline FID & Flame ionization detection & PLA & Polylactic acid \\
\hline HPLC & High performance liquid chromatography & RFU & Relative fluorescense unit \\
\hline LAB & Lactic acid bacteria & SHF & Separate hydrolysis and fermentation \\
\hline LB & Luria Bertani culture medium & SSF & $\begin{array}{l}\text { Simultaneous saccharification and } \\
\text { fermentation }\end{array}$ \\
\hline MM & Mineral Medium & TS & Total solids \\
\hline MRS & Man, Rogosa and Sharpe medium & UV & Ultraviolet radiation \\
\hline
\end{tabular}




\section{ADM}

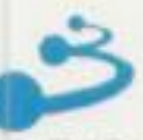

Paterna, a 12 de mayo de 2021

Por la presente, hacemos constar que D. Daniel Arturo Bustamante Jaramillo, estaba contratado en la empresa ADM BIOPOLIS y participaba en diversos proyectos de investigación (industrial y de desarrollo experimental) en el campo de la Biotecnología Industrial, que se estaban desarrollando en la empresa durante la ejecución de esta tesis doctoral. Esta linea de investigación en el que participa el doctorando está en relación directa con la tesis que realiza y su plan de investigación se somete a la aprobación por la Comisión Académica del Programa de Doctorado.

Las directoras:

Fdo.: Marta Tortajada Serra Fdo.: Antonia Rojas Martinez

Directora I+D

Responsable Lab. Bioenergias (Microbiologia)
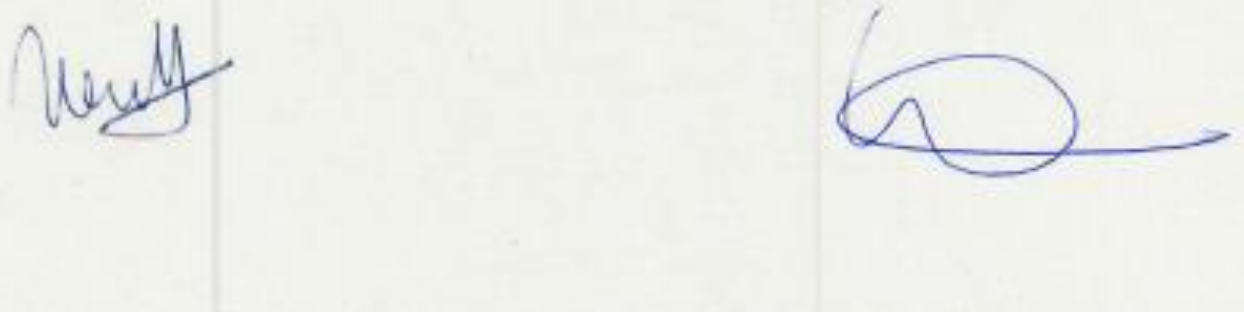



\section{AGRADECIMIENTOS}

Quiero agradecer en primer lugar a Marta Tortajada y Daniel Ramón por confiar en mí, dándome la oportunidad de trabajar en Biopolis. Sin duda, es allí donde he podido desarrollar gran parte de mi carrera profesional y donde fue creciendo cada vez más mi pasión por la biotecnología. A Antonia Rojas por ser la mejor jefa de laboratorio que he podido tener, por ayudarme y apoyarme siempre, tanto profesionalmente como en lo personal. Gracias por escuchar siempre todas mis inquietudes, por acompañarme y animarme durante todo este proceso. Agradezco también a Eduardo Palomares por escucharme cuando tenía la idea de emprender este proyecto y por estar siempre dispuesto a guiarme y resolver todas mis dudas.

Quiero agradecer a toda la gente de Biopolis con la que he coincidido y con la que he podido aprender tantas cosas, incluyendo a todos los estudiantes de prácticas y estancias que fueron pasando por el laboratorio (en especial a Martiuti y Serena, sois muy especiales). Agradezco especialmente a quienes fueron en su día mis compañeros de laboratorio: Bea, Silbia, Vero, Diego, Alex, Carlos, María S., Marta B., Guille, María E., Irina, etc. Han sido muchos momentos compartidos con vosotros y muchos de soportarme, siempre se os echa de menos. Gracias Bea y Carlos por vuestra amistad y por estar siempre que lo he necesitado. Gracias Ana, Rosa y Andrea por las conversaciones y darme ánimos en el tranvía de camino al trabajo, en aquellos días veía aún muy lejos este momento.

Mis agradecimientos a Victoria Santos y a Miguel Ladero, sois unos grandísimos profesores e investigadores, gracias por estar ahí siempre que he acudido a vosotros durante la carrera y posteriormente, especialmente durante todo este camino. Es una suerte enorme poder contar con vosotros.

Quiero extender mi agradecimiento a Isabel de la Mata, que siendo mi profesora en la carrera pudo apreciar mi interés en este campo, sin lo cual no sería posible haber llegado hasta aquí. Gracias Isabel por apoyarme y ponerme en contacto con Auxi Prieto, a quien agradezco infinitamente haberme dado la oportunidad de tener mi primer contacto con un laboratorio de biotecnología, una de las mejores experiencias. Gracias Nina por tu paciencia en aquella época y gracias Isabel, Valle, Virginia y Bea por ser tan majas y ayudarme en todo. 
Quiero agradecer a David Sánchez y Javier Gil por darme la gran oportunidad de seguir creciendo profesionalmente en CENER y a todos mis compañeros de departamento, de quienes aprendo cada día, en especial a Inés, Goizeder, Vicente, Idoya, Ibai, Blanca, Cris, Alberto, Laura, e Irantzu, etc. A todos mis compañeros en el BIO2C, especialmente a Raul, Xabi, Mercedes, Eduardo, Pili y Eva. Gracias Pili y Eva por vuestra disposición y vuestra paciencia, es un placer trabajar con vosotras.

Gracias a todos mis compañeros de máster: Ximo, María, Cris, Ana, Nuria, Carlos, Jesús, Dana, etc. Un placer haber podido coincidir con vosotros. Me habéis hecho todo mucho más llevadero, me habéis servido de inspiración con la vuelta a la universidad y a la hora de plantearme emprender este proyecto. Al final siempre acabamos reviviendo aquel grupo de whatsapp.

Agradezco a mis amigos: Carlos, Roberto, Josep, Alberto y José; siempre hartos de oírme hablar de la tesis, pero siempre a mi lado. Gracias por estar conmigo todos estos años y por tantos buenos momentos compartidos. Quiero incluir a Lou y a Carlos A., gracias por escucharme darme apoyo.

Finalmente, doy las gracias y dedico este trabajo a mi madre, a mi hermana y a toda mi familia. Gracias por tanto sacrificio y por estar ahí siempre. Me impulsáis a intentar mejorar y sin vosotros nada de esto sería posible.

En definitival, gracias a todos los que de una forma u otra habéis hecho posible desarrollar esta tesis doctoral. 